\title{
The Geology and Remarkable Thermal Activity of Norris Geyser Basin, Yellowstone National Park, Wyoming
}
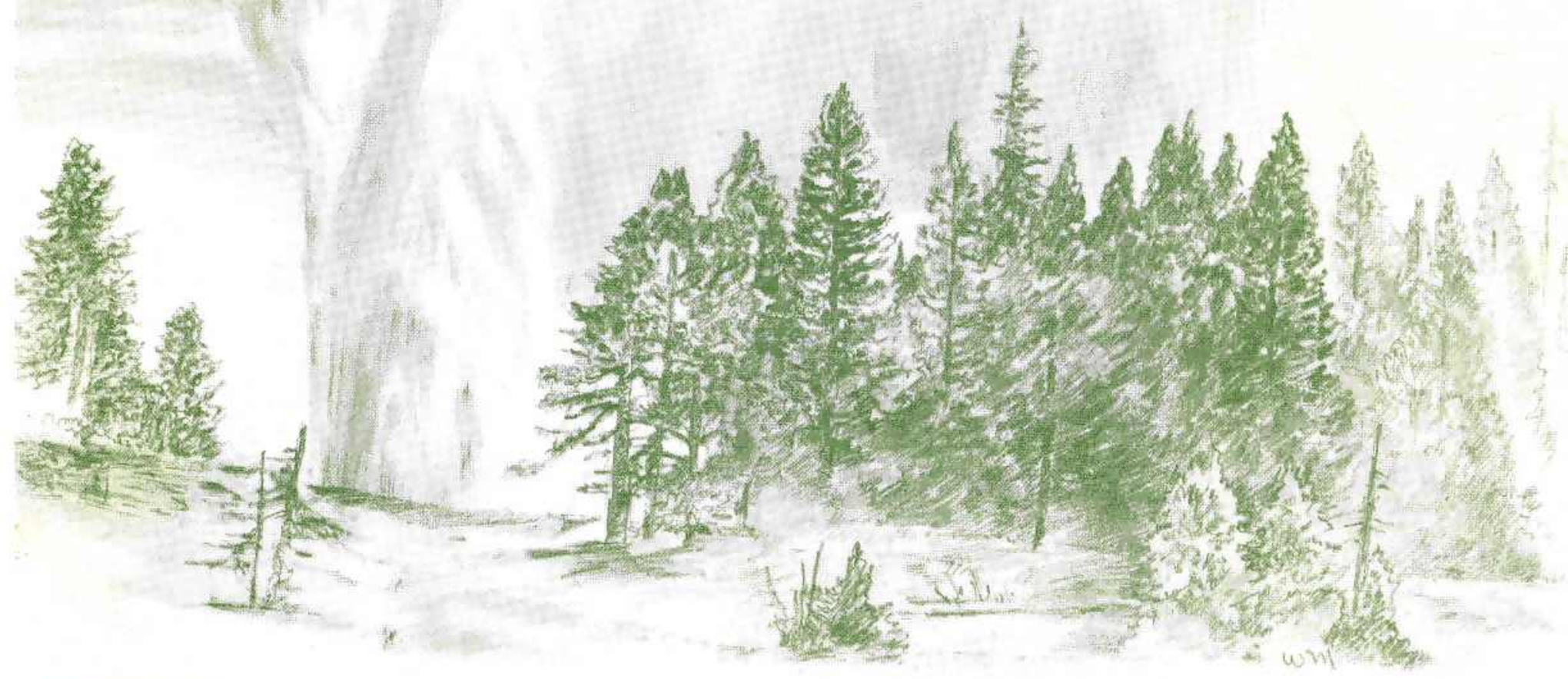

U.S. GEOLOGICAL SURVEY PROFESSIONAL PAPER 1456 
This page intentionally left blank 


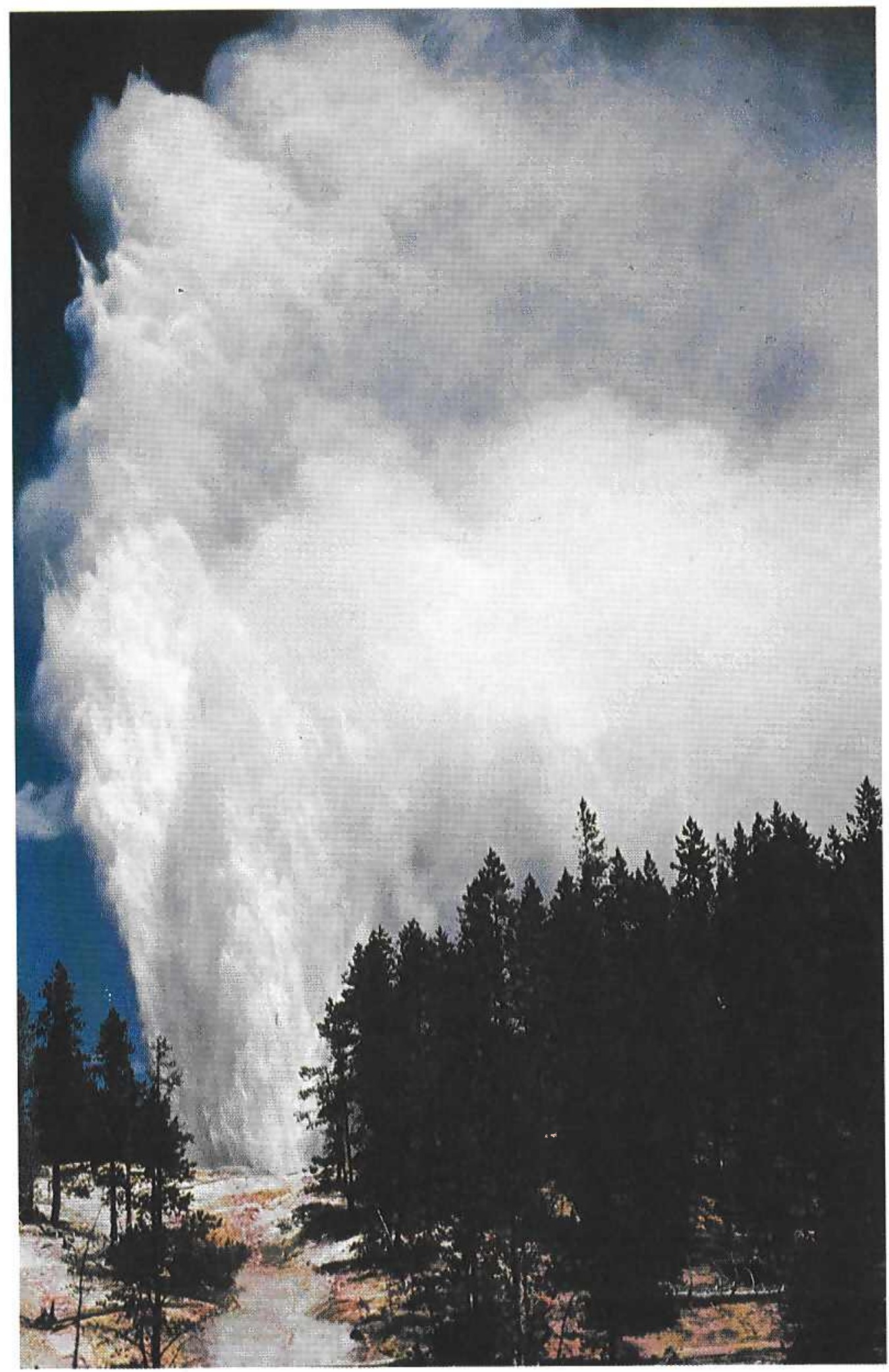

Steamboat Geyser in major eruption. Photograph, purchased by the National Park Service and reprinted here with their permission, was taken nearly due north up the discharge stream of the double vents. Fluids from the vents are indistinguishable, and both vents are erupting mixed steam and pulsating water, evidently early in the eruption sequence because discharged water has not yet topped the bridge over the main discharge stream. Indicated height relative to largest trees is estimated to be nearly 100 meters. Date the photograph was taken is unknown, but was probably prior to 1968. 


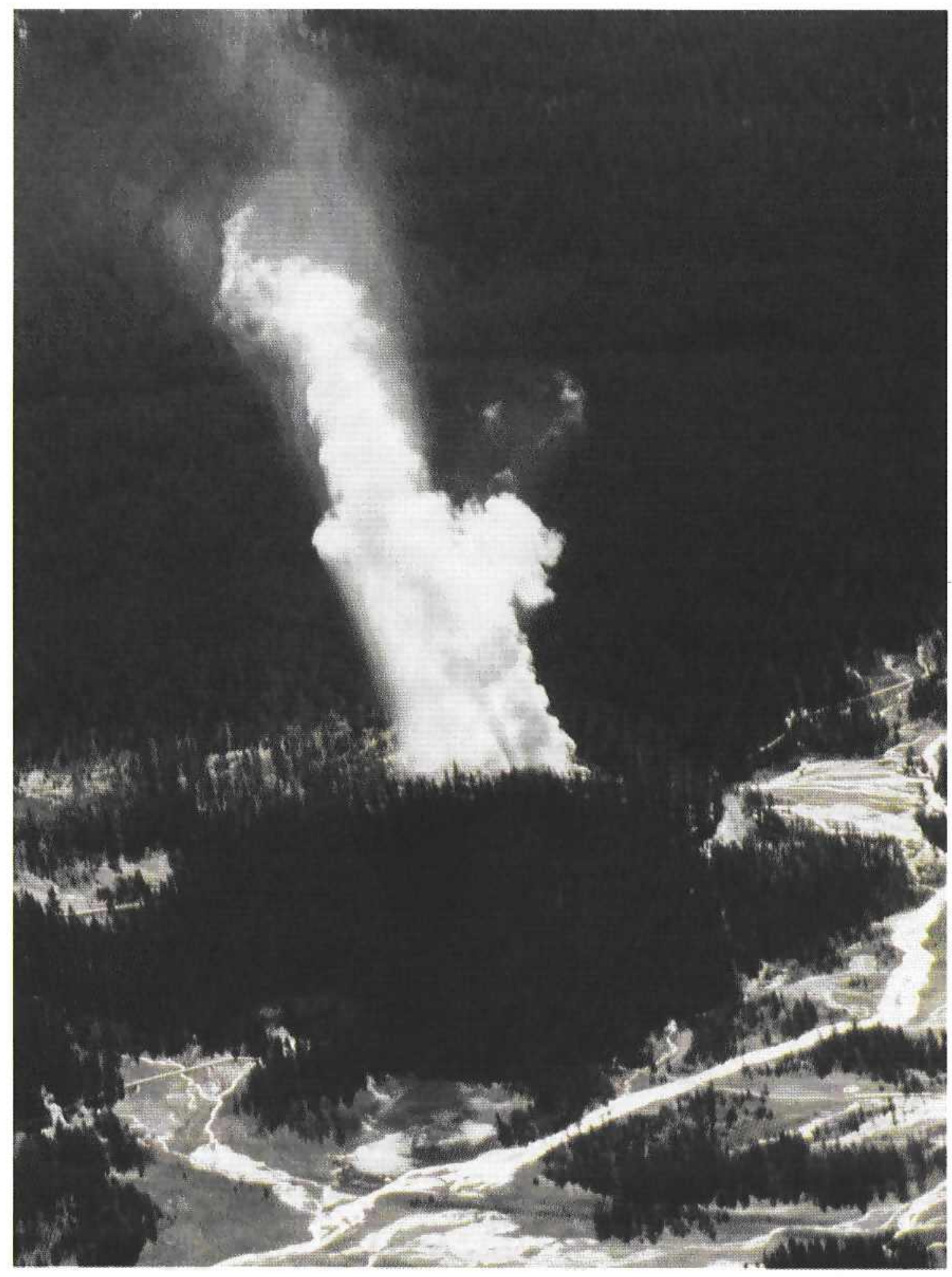

Aerial view of Steamboat Geyser erupting. Photograph shows clearly the abundant flooding of most channels to the south, southwest, and west-southwest (toward photographer). Eruption plume of water and steam is inclined to the northwest at an angle of approximately $15^{\circ}$ from vertical and reaches an estimated height of 130 meters or higher. Discharge from the southeastern vent is now mostly steam, as it has lost most of the jetted water evident in photograph on facing page. The water supply being discharged is tremendous-view is too high toestimate accurately, but probably about 20,000 liters per minute-and has probably continued at this high flow rate for at least 10 minutes. Photograph was taken by Robert B. Smith of the University of Utah on July 6, 1984. 


\section{The Geology and Remarkable Thermal Activity of Norris Geyser Basin, Yellowstone National Park, Wyoming}

By DONALD E. WHITE, R.A. HUTCHINSON, and T.E.C. KEITH

U.S. GEOLOGICAL SURVEY PROFESIONAL PAPER 1456

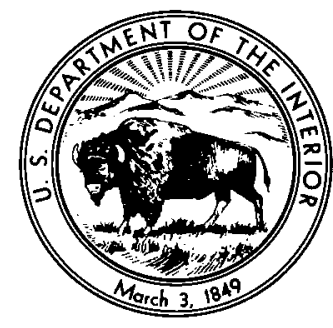

UNITED STATES GOVERNMENT PRINTING OFFICE, WASHINGTON : 1988 


\section{DEPARTMENT OF THE INTERIOR \\ DONALD PAUL HODEL, Secretary}

\section{U.S. GEOLOGICAL SURVEY}

Dallas L. Peck, Director

White, Donald Edward, 1914

The Geology and remarkable thermal activity of Norris Geyser Basin, Yellowstone National Park, Wyoming.

(U.S. Geological Survey Professional Paper 1456)

Bibliogiaphy

Supt. of Docs. No: I 19.16:1456

1. Geology-Wyoming-Norris Geyser Basin. 2. Geysers-Wyoming-Norris Geyser Basin. 3. Yellowstone National Park.

I. Hutchinson, R.A. II. Keith, Terry E.C. III. Title. IV. Series: Geological Survey Professional Paper 1456. QE182.N67W48 1987 557.8752

$87-600279$

For sale by the Books and Open-File Reports Section, U.S. Geological Survey, Federal Center, Box 25425, Denver, CO 80225 


\section{CONTENTS}

Abstract _. . . . . . . . . $\ldots \ldots$ Page

Introduction - - - - - - - - - - - - - - - - - 2

Acknowledgments - - - - - - - . - - 3

Summary settings of Norris Geyser Basin - - - - - - - 3 Geology and volcanic history - - - - - - - - - 3 Glacial history - - - - - - - - - - - - - 5 Hydrothermal activity $\ldots \ldots \ldots \ldots-\ldots \ldots$

Rocks and sediment of Norris Geyser Basin- _ - . - - - 7 Lava Creek Tuff _. $\ldots \ldots \ldots \ldots$ Geochemistry of the common silica minerals and diagenesis

of hot-spring sinters - - - - - - - . - 8

Hydrothermal quartzite - - $\ldots \ldots \ldots \ldots-\ldots 11$

Pre-Pinedale chalcedonic sinter - - - - - - - - - - 13

Older Pinedale cemented kames - - _ - _ - _ - - 14

Younger Pinedale glacial deposits - - - - - - - 16

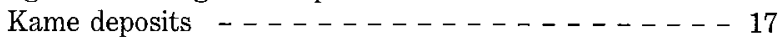

Till - - - - - - - - - - - - - - 17

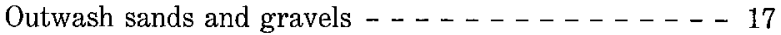

Cemented younger Pinedale deposits _ _ . - . - 18

Hydrothermal explosion breccia - - - - - - - - 18

Holocene sinter deposits $-\ldots \ldots \ldots \ldots \ldots$

Alluvial and lacustrine deposits - - - - - - - - -22

Structure - - - - - - - - - - - - - - - 24

Faults - - - - $-\ldots-\ldots-\ldots-\ldots-\ldots 24$

Fractures - - - - . - . - . - . . - - 24

Summary of chemical water types and their proposed origins- - 25

Nearly neutral waters high in $\mathrm{Cl}$ and $\mathrm{SiO}_{2}-\mathrm{S}_{-----25}$

Dilute recharging meteoric waters - - - - - - - - 26

Acid $\mathrm{Cl}-\mathrm{SO}_{4}$ (or $\mathrm{SO}_{4}$-Cl) waters $-\ldots \ldots \ldots$

Acid-sulfate waters - _ _ _ _ _ _ _ - . - 28

Recent hydrothermal activity of Norris Geyser Basin - - - - - 28

Africa Geyser - - - - - - - - - - - - - - 39

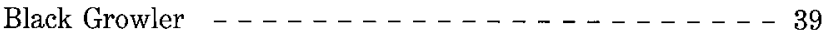

Carnegie II drill hole - $\ldots \ldots \ldots-\ldots \ldots \ldots$

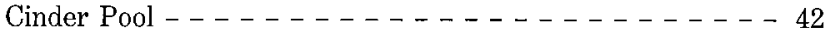

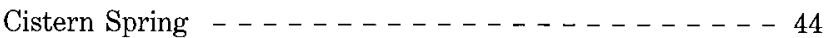

Congress Pool - - - - - - - - - - - - 446

Echinus Geyser - - - - - - . - - - - - - - 46

Green Dragon Spring _ . . . . . . . . . . . . - 47
Recent hydrothermal activity of Norris Geyser Basin-Continued Page Harding Geyser $\ldots \ldots \ldots \ldots 7$

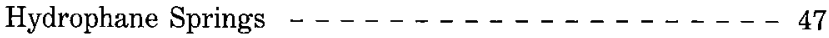

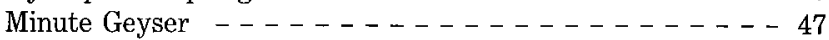
Monarch Geyser Crater - _ . . . . . . . . - 51

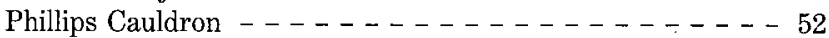
Porcelain Terrace and Porcelain Springs - - - - - - - 52 Porkchop Geyser (spring) - _ - _ - _ - _ - - - 53

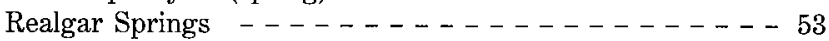
Steamboat Geyser _ - - - - - _ - _ - - - 54

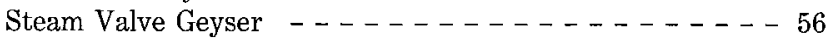

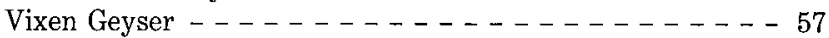
Whirligig Geysers _ $\ldots \ldots \ldots \ldots$ Other notable features $\ldots \ldots \ldots-\ldots-\ldots$

Widespread contemporaneous changes $--{ }_{-}--_{-}--61$ Rocks and alteration mineralogy of drill holes, Norris Geyser

Basin - . . . . . . . . . . . . . . 62

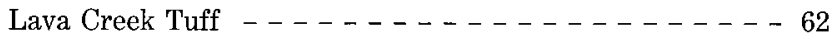

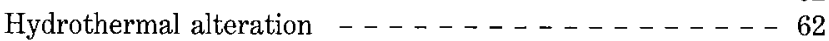

Characteristics of the drill core from Y-9 - - - - 67

Characteristics of the drill core from Y-12 - - - - 68

Characteristics of the drill core from C-II _ - - - - 69

Controls of hydrothermal alteration _ _ _ _ _ - - -70

Summary of hydrothermal alteration - - - - - . - - 71

Heat and mass flows from Norris Geyser Basin - - - - - - 71

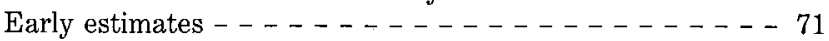

Chloride inventories of Gibbon River, 1966-67 _ - - - - 72

Additional data on $\mathrm{Cl}$ inflow to the Upper Gibbon

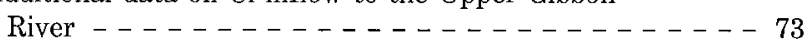

History and continuity of hydrothermal activity, Norris-

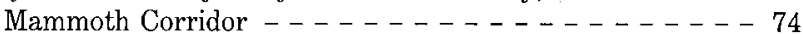

A new model for continuous long-lived hydrothermal systems- - 76 Three hydrogeologic models for present hydrothermal activity

in the Norris-Mammoth Corridor _._.

Explanations for widespread disturbances of Norris thermal

features and intimate associations of different water

types - - - - - - - - - - - - - - - - 77

Conclusions - - - - - - - - - - - - - - - - 88

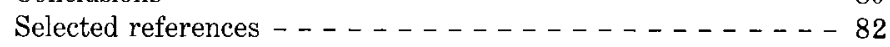

\section{ILLUSTRATIONS}

FRoNTISPIECES. Photographs of Steamboat Geyser in major eruptions.

Plate 1. Geology and thermal features of Norris Geyser Basin _ $\ldots \ldots \ldots \ldots$

Figure 1. Maps of Yellowstone Park and Norris Basin, showing topographic features, rivers, lakes, calderas, major fracture zones, faults, surrounding mountain ranges, epicenters of earthquakes, the third-cycle caldera rim, the ring-fracture zone, resurgent domes, and active and fossil hydrothermal systems _ _ . . . . . 
FIgURE 2. Vertical section through Norris Basin drill holes, showing temperature contours from bottom-hole data as drilling progressed and a hypothesized fracture to explain interference between hole Y-9 and Carnegie II _...

3. Photograph of drill core from drill hole Y-9 $\ldots \ldots \ldots \ldots \ldots \ldots \ldots \ldots \ldots$

4. Graph of the solubilities of the common silica minerals along the two-phase curve of water and vapor $\ldots$

5. Aerial view looking eastward over explosion crater $\ldots \ldots \ldots \ldots \ldots \ldots \ldots \ldots$

6-17. Photographs of:

6. Vents and eruption debris, south base of Porcelain Terrace $\ldots \ldots \ldots$

7. Self-sealing multiple vents southeast of Opal Spring _ $\ldots \ldots \ldots \ldots \ldots$

8. Cistern Spring three hours after Steamboat Geyser had started its major eruption of June 3, 1968---

9. Coral Spring discharging high- $\mathrm{SiO}_{2}$ water (opalescent) $-\ldots-\ldots-\ldots-\ldots-\ldots-\ldots-\ldots$

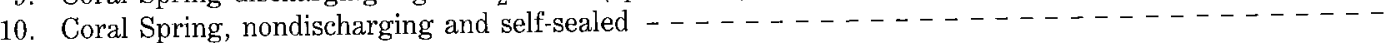

11. Porkchop Geyser after its eruption of Sept. 3, $1972 \ldots---_{-}--_{-}--_{-}--_{-}--_{-}$

12. Closeup of north end of Porkchop Geyser, showing pine needles, small cones, and grass encased by opaline $\mathrm{SiO}_{2}$

13. Porkchop Geyser showing flowline trends in sinter

14. Ledge Geyser's multiple vents, showing a northwest-striking fracture in Lava Creek Tuff - - - - -

15. Valentine Geyser and dispersed vents of Black Growler fumaroles $\ldots \ldots \ldots \ldots$

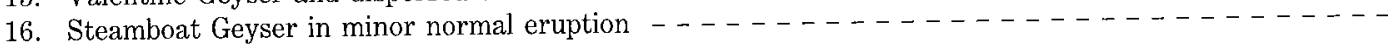

17. Hydrophane Springs after widespread reactivation in $1982 \ldots \ldots \ldots \ldots$

18-19. Aerial photographs:

18. Looking north-northwest over Norris Basin _ $\ldots \ldots \ldots \ldots \ldots$

19. Looking west-northwest over Nuphar Lake, Porcelain Basin, and the Annex Area

20. Rose diagrams of fracture trends in Norris Basin, as compared with trends of 200 points of random values- 21-41. Photographs of:

21. A warm dilute acid spring believed to represent acid meteoric recharge from near the crest of Norris

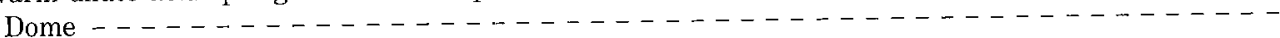

22. Echinus Geyser erupting acid $\mathrm{SO}_{4}$ - $\mathrm{Cl}$ water $\ldots \ldots \ldots \ldots$

23. Echinus Geyser pool and discharge area about 5 minutes after the end of an eruption in 1965

24. Green Dragon Spring, discharging acid $\mathrm{Cl}_{-} \mathrm{SO}_{4}$ water of long-debated origin $\ldots \ldots$

25. Central Porcelain Basin, with many acid and a few neutral springs; looking northeast to Porcelain

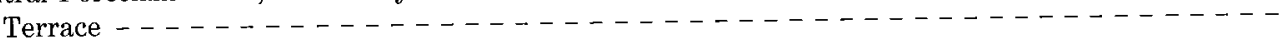

26. Merging of nearly neutral and acid discharge streams in Porcelain Basin

27. Yellow Funnel Spring, showing color variations _ $\ldots \ldots \ldots \ldots \ldots$

28. Sulfur Dust Spring depositing flocculated elemental sulfur but little or no sinter $---_{-}--_{-}-{ }_{-}$

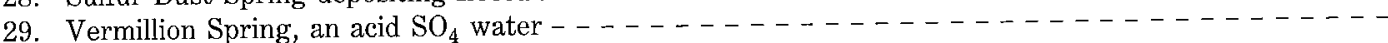

30. Black Growler fumarole - _ - _ $\ldots \ldots \ldots \ldots \ldots$

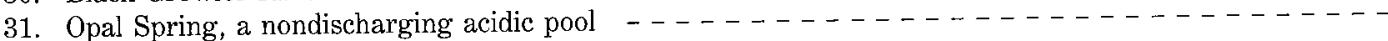

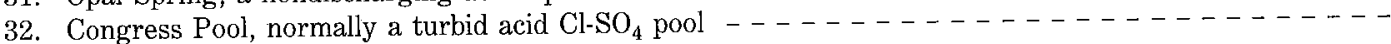

33. Congress Pool, four weeks after figure 32 was taken $-\ldots-\ldots \ldots \ldots$

34. Cinder Pool, half covered with floating black "cinders" consisting of elemental sulfur and dispersed

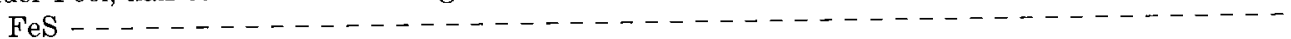

35. Steam Valve Spring reactivated, and between eruptions $\ldots \ldots \ldots$

36. Concrete monument and rocks to stabilize Carnegie II drill hole $\ldots \ldots-\ldots \ldots \ldots \ldots-\ldots$

37. Dark Cavern Geyser, looking east to Black Growler fumarole $-{ }_{-}-n_{-}--_{-}--_{-}--_{-}$

38. Steaming ground 10 to $20 \mathrm{~m}$ southeast of Carnegie II $\ldots \ldots-\ldots$

39. Y-9 drill hole after core barrel was withdrawn from $-210 \mathrm{~m}-\ldots-\ldots-\ldots-\ldots-\ldots-\ldots$

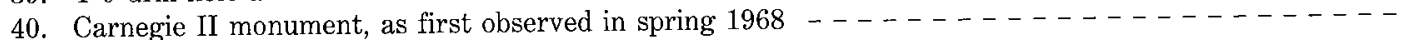

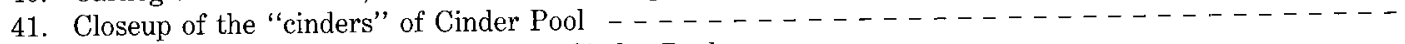

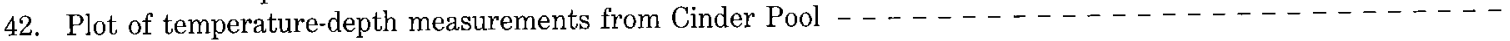
43-48. Photographs of:

43. Thermistor probe after withdrawal from Cinder Pool
44. Cistern Spring drained 5 to $7 \mathrm{~m}$ below overflow in response to a major eruption of Steamboat

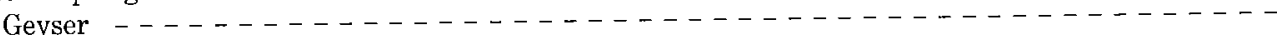

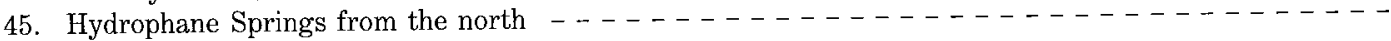

46. Minute Geyser in major eruption, September $1947-\ldots-\ldots-\ldots-\ldots-\ldots-\ldots-\ldots$

47. Phillips Cauldron, a mud volcano that was vigorously active in $1947 \ldots-\ldots-\ldots$

48. Ornate terraced sinter vent of a short-lived spring at the south end of Porcelain Terrace

49. Plot of temperature-depth measurements from vents of Steamboat Geyser, Norris Geyser Basin - - - - -

50. Aerial photograph of central Norris Basin looking north over parts of Back and Porcelain Basins 51-61. Photographs of:

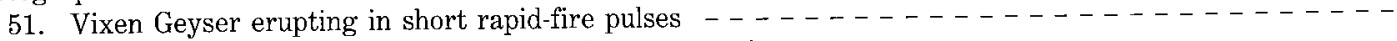

52. Whirligig Geyser vent, almost drained after an eruption $--_{-}--_{-}--_{-}--_{-}--_{-}$

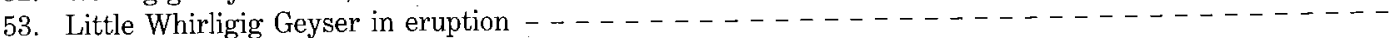

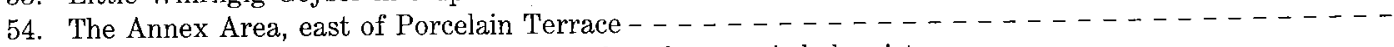

55. Primrose Springs, showing contrasting colors from varied chemistry $-\ldots----_{-}--_{-}--_{-}$ 
FIgURE 56. Porcelain Springs at the base of Porcelain Terrace $\ldots \ldots \ldots \ldots$

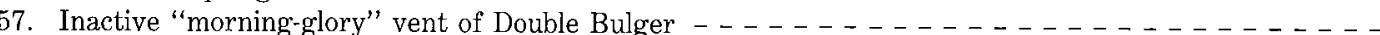

58. Site of Y-12 drill hole near the "treeline" heat-flow contour east of Opal Spring, Porcelain Terrace - -

59. An area north-northwest of Steamboat Geyser where high heat flow has melted snow more rapidly than in adjacent areas $\ldots \ldots \ldots \ldots$

60. Rime that grows upward from freezing of condensing convected water vapor at the air-soil interface - - . - - $\ldots \ldots \ldots \ldots$

61. Accumulated frozen spray about $4 \mathrm{~m}$ thick from Africa Geyser, melting mainly from the base

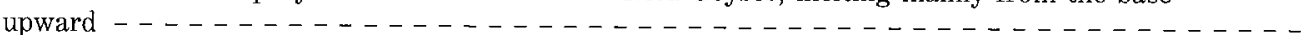

62-64. Graphs showing the temperatures and distribution of mineral phases in:

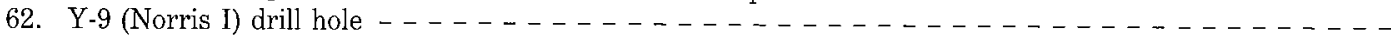

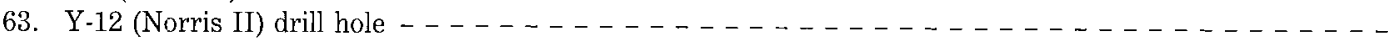

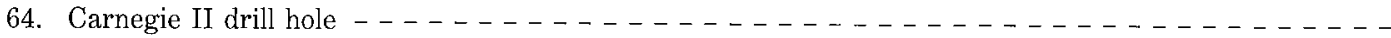

65. Scanning electron micrograph of bastnaesite from $-119.3 \mathrm{~m}$ in drill core $\mathrm{Y}-9, \ldots \ldots$

66. Photograph of drill core from $-92.7 \mathrm{~m}$ in Y-12 drill hole, showing three stages of hydrothermal alteration - -

67. Aerial photograph of Roaring Mountain $\ldots \ldots \ldots \ldots \ldots$

68. Diagrammatic north-trending section along Norris-Mammoth Corridor, one of several alternative models - - -

69. Diagrammatic enlargement of Norris Geyser Basin, showing one model of circulation patterns that can explain the distribution and evolution of the principal water types

\section{TABLES}

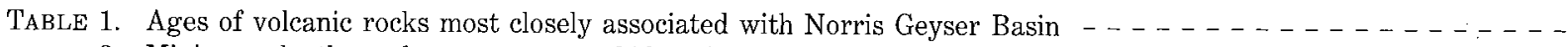

2. Minimum depths and temperatures of identified hydrothermal K-feldspar (adularia), chalcedony, and

$\beta$-cristobalite in research drill holes, Yellowstone National Park $\ldots \ldots \ldots \ldots$

3. Rocks exposed in vent of north Hydrophane Springs- $\ldots \ldots \ldots \ldots$

4. Chemical compositions of principal water types occurring in and near Norris Geyser Basin $\ldots$

5. Summary of notable thermal features, Norris Geyser Basin $\ldots \ldots \ldots \ldots \ldots \ldots-\ldots$

6. Thermal features of Norris Geyser Basin known to have erupted as geysers $\ldots \ldots \ldots$

7. Recorded major eruptions of Steamboat Geyser, Norris Geyser Basin, 1878 through June $1984 \ldots \ldots$

8. Widespread disturbances, each of which affected two or more thermal features of Norris Geyser Basin nearly

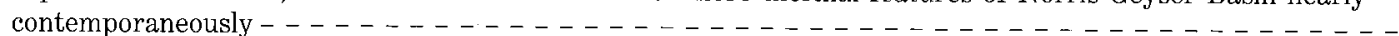




\title{
THE GEOLOGY AND REMARKABLE THERMAL ACTIVITY OF NORRIS GEYSER BASIN, YELLOWSTONE NATIONAL PARK, WYOMING
}

\author{
By Donald E. White, R.A. Hutchinson, ${ }^{1}$ and T.E.C. Keith
}

\section{ABSTRACT}

Norris Geyser Basin, normally shortened to Norris Basin, is adjacent to the north rim of the Yellowstone caldera at the common intersection of the caldera rim and the Norris-Mammoth Corridor, a zone of faults, volcanic vents, and thermal activity that strikes north from the caldera rim to Mammoth Hot Springs. An east-west fault zone terminates the Gallatin Range at its southern end and extends from Hebgen Lake, west of the park, to Norris Basin.

No local evidence exists at the surface in Norris Basin for the two oldest Yellowstone volcanic caldera cycles ( $\sim 2.0$ and 1.3 m.y.B.P.). The third and youngest cycle formed the Yellowstone caldera, which erupted the 600,000-year-old Lava Creek Tuff. No evidence is preserved of hydrothermal activity near Norris Basin during the first 300,000 years after the caldera collapse. Glaciation probably removed most of the early evidence, but erratics of hot-spring sinter that had been converted diagenetically to extremely hard, resistant chalcedonic sinter are present as cobbles in and on some moraines and till from the last two glacial stages, here correlated with the early and late stages of the Pinedale glaciation $(<150,000$ years B.P.).

Indirect evidence for the oldest hydrothermal system at Norris Basin indicates an age probably older than both stages of Pinedale glaciation. Stream deposits consisting mainly of rounded quartz phenocrysts of the Lava Creek Tuff were subaerial, perhaps in part windblown and redeposited by streams. A few small rounded pebbles are interpreted as chalcedonic sinter of a still older cycle. None of these are precisely dated but are unlikely to be more than 150,000 to 200,000 years old.

The dominant quartz sand is hydrothermally cemented by chalcedony and is extremely hard, thereby justifying the term hydrothermal quartzite. Comparison with other sinter-depositing hot-spring systems indicates that the upper part of this fossil western Norris system was completely stripped by glacial erosion, leaving its chalcedonized roots but no sinter. Hydrothermal K-feldspar (adularia) is present locally, indicating channels of former upflowing spring water. Comparison with other drilled sinter-depositing systems suggests that at least $10 \mathrm{~m}$ of chalcedonic sinter has been eroded. Some combination of time $(10,000$ years or more) and high temperature (above surface boiling, perhaps $\sim 120^{\circ} \mathrm{C}$ ) was necessary to reconstitute the initial amorphous opal to chalcedony; the same general depths and temperatures are also essential to form adularia. The Al content of this hydrothermal feldspar is probably derived from volcanic feldspars or glass.

The fundamental water type in Norris Basin is nearly neutral in $\mathrm{pH}$ and high in $\mathrm{Cl}$ and $\mathrm{SiO}_{2}$. Its $\mathrm{SiO}_{2}$ content depends on its temperature of equilibration with respect to quartz, which is abundant in the under-

JU.S. National Park Service, Yellowstone National Park. lying rhyolitic rocks, and on how much $\mathrm{SiO}_{2}$ was precipitated enroute to the surface. Temperatures immediately below Norris are probably near $270^{\circ} \mathrm{C}$, a temperature that would be demanded by the high initial $\mathrm{SiO}_{2}$ content of the neutral high-Cl waters. Boiling enroute to the surface concentrated both $\mathrm{Cl}$ and $\mathrm{SiO}_{2}$ in the residual liquid, attaining contents of $>700 \mathrm{ppm}$ for each. Contents of $\mathrm{SO}_{4}$ and combined $\mathrm{CO}_{2}$ species are generally low.

Another common type of water in Norris Basin is high in $\mathrm{SO}_{4}$ and moderately high in $\mathrm{Cl}$, with $\mathrm{Cl} / \mathrm{SO}_{4}$ ratios differing considerably. In general, the lower the $\mathrm{Cl}$, the greater the indicated dilution by meteoric water with little or no more than $5 \mathrm{ppm} \mathrm{Cl}$. Sulfate is formed by surface or near-surface reaction of $\mathrm{H}_{2} \mathrm{~S}$ with atmospheric oxygen (or with ferric iron formed from ferrous iron during oxidation of the initial ashflow tuffs).

A second type of acid $\mathrm{Cl}-\mathrm{SO}_{4}$ water in Norris Basin is most abundant in the southwestern part of the basin where some meteoric recharge is not chemically neutral, as normal, but contains sulfuric acid, probably obtained from the recharge area by oxidizing $\mathrm{H}_{2} \mathrm{~S}$ and native $\mathrm{S}$. A source of acid warm meteoric recharge also seems to be near the crest of Norris Dome.

A minor type of water, acid $\mathrm{SO}_{4}$, is dominated by sulfuric acid and soluble constituents leached from the local rocks. This water is generally close to boiling; it commonly occurs on slightly higher ground and is surrounded and underlain by saline waters of other types. This acidsulfate water originates by boiling of one of the other types, probably in the shallow subsurface (centimeters to meters in depth). Steam, $\mathrm{CO}_{2}$, and $\mathrm{H}_{2} \mathrm{~S}$ are the dominant gases; part of the steam condenses in cooler surface pools of low discharge and then evaporates as $\mathrm{H}_{2} \mathrm{~S}$ oxidizes to $\mathrm{SO}_{2}$ or $\mathrm{SO}_{3}$. Rain and snow also supply a part of the local water, diluting other constituents.

This study provides no new conclusive data on an old problem, the source or sources of rare dissolved constituents. Common assumptions are that the water is entirely of meteoric origin and that the dissolved matter is derived from water-rock reactions at high temperatures. Our preferences continue to favor volcanic heat, much volcanic $\mathrm{Cl}, \mathrm{S}, \mathrm{CO}_{2}$, and some $\mathrm{H}_{2} \mathrm{O}$ and nonvolatile constituents, much recycled meteoric water with extensive redistribution of constituents through water-rock interaction, and also some metamorphic water from dehydration reactions, especially from sedimentary or deep crustal rocks as silicic magma is being generated by basalt and heat from the mantle. If hydrothermal activity of the Norris-Mammoth Corridor correlates closely with magnitudes and ages of corridor rhyolite extrusive centers, as we favor, support for the above is strengthened.

An important part of this paper consists of examples of numerous changes in behavior and chemical composition of most springs and 
geysers, to extents not known elsewhere in the park and perhaps in the world. Evolution of individual vents seems to be going on continually; many are rapid changes involving only a single vent, but some are widespread changes involving numerous vents crudely aligned to the north and northeast for $1 / 2$ to $2 \mathrm{~km}$, parallel to common fracture trends. These widespread changes seem to be seasonally controlled, being most common in August and September and perhaps related to scarcity of local water on the floors of Porcelain and Back Basins.

Hydrothermal mineralogy in core samples from three research holes drilled entirely in Lava Creek Tuff to a maximum depth of $-331.6 \mathrm{~m}$ permits an interpretation of the hydrothermal alteration history. Primary plagioclase and mafic phenocrysts were completely removed at an early stage of alteration. $\mathrm{Fe}$ and $\mathrm{Mn}$ were mobilized early, and $\mathrm{Fe}$ oxides were pervasively deposited in the tuff. Fractures were filled with cryptocrystalline mixtures of chalcedony, clays, and $\mathrm{Fe}$ oxides. In two drill holes, subsequent alteration was superimposed upon the earlier oxidation, resulting in intervals of bleaching of tuff in which the Fe oxide was reduced to sulfide. Fluctuating water compositions are commonly associated with refracturing of the tuff, seen where several stages of alteration are superimposed. A deep, mildly acidic alteration is indicated by bleached tuff and an assemblage of pyrite, chlorite, and mixed-layer illite-montmorillonite in the deepest drill hole. Near-surface acid fluids have bleached the upper levels of tuff in all three drill holes, resulting in deposition of alunite, kaolinite, opal, $\beta$-cristobalite, $\alpha$-cristobalite, and locally sulfides. Fluids recirculating downward deposited kaolinite, $\alpha$-cristobalite, and chalcedony in latest fractures. In the present system, self-sealing (mainly by silica-clay mixtures that depend on temperature and water composition) is taking place. Locally, two or more stages of alteration may be distinguished, but no certain criteria were recognized to correlate all alteration stages with differences in contemporaneous surface activity.

Most studies of active hydrothermal areas have noted chemical differences in fluids and alteration products but have given little attention to differences and models to explain evolution in types. This report, in contrast, emphasizes the kinds of changes in vents and their changing chemical types of waters and then provides models for explaining these differences.

Norris Basin is probably not an independent volcanic-hydrothermal system. The basin and nearby acid-leached areas (from oxidation of $\mathrm{H}_{2} \mathrm{~S}$-enriched vapor) are best considered as parts of the same system, extending from Norris Basin to Roaring Mountain and possibly to Mammoth. If so, are they parts of a single large system centered within the Yellowstone caldera, or are Norris Basin and the nearby altered areas both parts of one or more young independent corridor systems confined, at least in the shallow crust, to the Norris-Mammoth Corridor? Tentatively, we favor the latter relation, probably having evolved in the past $\sim 300,000$ years.

A model for large, long-lived, volcanic-hydrothermal activity is also suggested, involving all of the crust and upper mantle and using much recent geophysical data bearing on crust-mantle interrelations. Our model for large systems is much superior to previous suggestions for explaining continuing hydrothermal activity over hundreds of thousands of years, but is less attractive for the smaller nonhomogenized volcanic system actually favored here for the Norris-Mammoth Corridor.

\section{INTRODUCTION}

Norris Geyser Basin, for many geologists, geochemists, and park visitors, is the most interesting and diverse thermal area in Yellowstone Park. The reasons, supported in detail in this report, are:

1. The basin includes most varieties of hot springs, geysers, fumaroles, and mud volcanoes found elsewhere in the park. Only travertine $\left(\mathrm{CaCO}_{3}\right)$ depositing springs are absent. Steamboat Geyser (>100 $\mathrm{m}$ high at peak of major eruptions) is the park's highest erupting geyser of historical record; Black Growler fumarole (as hot as $138^{\circ} \mathrm{C}$, Allen and Day, 1935) has the highest recorded surface temperature; and research drill hole Y-12 has the highest temperature yet measured in the park $-237.5^{\circ} \mathrm{C}$ at $331.6 \mathrm{~m}$ depth (White and others, 1975)-and also has the highest temperature yet recorded for its depth in world geothermal systems (excluding volcanoes and directly related volcanic fumaroles).

2. Norris Basin displays a wide variety of chemical types of waters, precipitates, and altered rocks, including nearly the total range found elsewhere in the park.

3. The area demonstrates the longest history of thermal activity of any of the major geyser basins. Initial activity, although not well dated, predates all deposits of the Pinedale stages of glaciation (about 12,000 to 115,000 years B.P.) and probably exceeds 150,000 years B.P. In contrast, the Firehole River geyser basins provide no evidence for activity older than early Pinedale glaciation.

4. Changes in activity in Norris Basin occur more frequently and often more vigorously than in other Yellowstone thermal areas. Change is characteristic of all high-temperature sinter-depositing geothermal systems, but is especially characteristic of Norris Basin, probably related to its exceedingly high subsurface temperatures and the highest $\mathrm{SiO}_{2}$ contents of all thermal waters in the park.

A significant part of this report describes the great variety of chemical and physical changes observed in Norris thermal features, such as springs changing to geysers and vice versa. Earthquakes and other stimuli may cause a spring to change its chemical type or a geyser to change its characteristics of eruption. Perhaps more than in any other geyser area, magnitudes and intervals of eruption may change, commonly with little warning or predictability. Norris Basin contains at least 70 thermal features and probably many more, inadequately recorded, that have erupted as geysers. The plumbing systems of at least some geysers in Norris Basin must have far greater variation and complexity than are assumed in most geyser models. The different parts of complex reservoirs may respond on different time scales and from different depths, at least in part correlating with a general increase in fluid pressures and pressure gradients with increasing depth (White and others, 1975). Detailed analyses of the geyser mechanisms are specifically excluded from this report, as much has already been written on this subject (White, 1967; Hutchinson, Yellowstone informal records, summarized in tables 6 and 7) and more is reserved for later reports. 
Hydrostatic pressures and overpressures and the change in local pressure gradients by the filling or selfsealing of flow channels from precipitating silica (and other hydrothermal minerals) are the key factors most likely to account for many of the changes frequently occurring in Norris Basin. These changes, seldom observed or recorded elsewhere in much detail, are a major subject of this report. Norris provides superb opportunities to compile such a record, probably exceeded at no other geothermal locality in the world. The present combination of authors provides many years of field and theoretical experience in observing and analyzing these geothermal phenomena. In addition, we have benefited from the vast knowledge, interest, and experience of our associates in the U.S. Geological Survey and the U.S. National Park Service.

\section{ACKNOWLEDGMENTS}

The scope of this report is limited mainly to surface and drill-hole geology and the physical aspects of the thermal systems, reserving detailed discussion of the complex chemistry and isotope relations of the fluids to the major geochemist participants, R.O. Fournier, A.H. Truesdell, and J.M. Thompson, for later reports. However, we have utilized published and open-filed chemical analyses by these and other individuals to provide the essential chemical framework for Norris Basin water types. We are also deeply indebted to these individuals for collaborative efforts on all Norris studies and for many hours of discussion on mutual problems. We are especially indebted to A.H. Truesdell for first suggesting horizontal flow of deep high-chloride waters involving selective boiling and escape of gases, thereby accounting for acid bleaching but few visible chloride-bearing springs between Norris Basin proper and Roaring Mountain. Manuel Nathenson assembled the equipment used in obtaining critical temperature profiles in Cinder Pool, Steamboat Geyser, Echinus Geyser, and other accessible vents and has been an invaluable consultant on all matters concerning conductive and convective heat flow. Amy Cook and Mary Ann Mikus, respectively, struggled patiently through many versions of the drafting of plate 1 and the revising of the Norris text, as these evolved over the years.

This report is also an appropriate vehicle to incorporate and acknowledge the extensive studies and informal Norris records of changing activity, as recorded in the written records prepared by National Park Service naturalists, preserved in the Norris and Mammoth Museums, and generally cited as "Yellowstone informal records"; names and dates are specified when known. R.A. Hutchinson of the U.S. National Park Service has had a specially long-sustained interest in Norris Basin; it seems most appropriate for him to be both a formal coauthor of this report, as well as the representative of the dozens of Park Service personnel responsible for these extensive Norris written records. Of special importance are the possible relations between widespread disturbances of thermal features, hydrofracturing from selfsealing, and seasonal occurrences, most commonly in the months of August and September.

\section{SUMMARY SETTINGS OF NORRIS GEYSER BASIN}

\section{GEOLOGY AND VOLCANIC HISTORY}

Norris Geyser Basin is just outside the northwest rim of the 600,000-year-old Yellowstone caldera (fig. 1), the youngest of three major cycles of caldera-forming events in the park (Eaton and others, 1975; Christiansen, in press). Norris Basin is also within a complex subsidence structure that extends northward nearly $30 \mathrm{~km}$ from the young caldera margin to Mammoth Hot Springs. This structural complex, here called the Norris-Mammoth Corridor, contains most of the young rhyolitic domes and basaltic lava vents of the past few hundred thousand years that are located outside the caldera margin. Norris Basin also lies on the eastward extension of the Hebgen Lake fault system, which bounds the Madison Range on the south (Smith and Christiansen, 1980; fig. 1). The most violent historical earthquake of the region occurred on this fault on August 17, 1959 (Marler, 1964; Richter magnitude, $M$, of 7.3). The same fault system, upthrown to the north, may also constitute the subsurface southern limit of the Gallatin Range, now concealed beneath ash-flow tuffs from the Yellowstone caldera. The surface expression of the Hebgen Lake fault system does not extend as far east as Norris Basin, but earthquake epicenters near this general extension constitute a considerable part of total seismic activity recorded in the park (Trimble and Smith, 1975; Smith and Christiansen, 1980; fig. 1).

The history of volcanism in the region has been studied in detail by Christiansen $(1979,1982,1984)$. Three volcanic cycles of ash-flow-tuff eruptions, each followed by a caldera collapse, have affected the park during the past two million years (table 1). Activity especially pertinent to Norris Basin began with eruption of the Lava Creek Tuff from the huge $40-\mathrm{km}$ by $60-\mathrm{km}$ Yellowstone caldera about 600,000 years ago. No local influence on Norris Basin by the earlier 2.0-m.y.-old or the 1.3-m.y.old cycles of ash flows and calderas has yet been recognized. The Lava Creek Tuff consists of two members, one (member A) from vents in the southwestern part of the double caldera and the second (member B) immediately following from the northeastern part. These two Lava Creek members constitute the dominant visible bedrock of Norris Basin. 
The flows, domes, and approximate ages of some of the rhyolites assigned by R.L. Christiansen and his associates to the Central Plateau and Roaring Mountain members of the Plateau rhyolites in the area near Norris Basin are listed in table 1. The Gibbon River flow ( $~ 90,000$ years B.P.) and the Norris Dome (160,000 years B.P.) of this report are significant to Norris Basin, but the Roaring Mountain member of the Plateau rhyolites initiated rhyolitic activity in the Norris-Mammoth Corridor be- tween 320,000 and 400,000 years B.P. (Willow Park and Cougar Creek domes), followed by the extrusion of domes and flows 180,000 to $\sim 80,000$ years B.P., erupted from magma sources perhaps nearest to the Norris Basin hydrothermal activity. The Gibbon River flow is the youngest dated flow of the area $(\sim 90,000$ years B.P.) and is important because its northern lobe bounds Norris Basin on the south (Christiansen, 1975) and dammed the southward flow of early Pinedale ice.

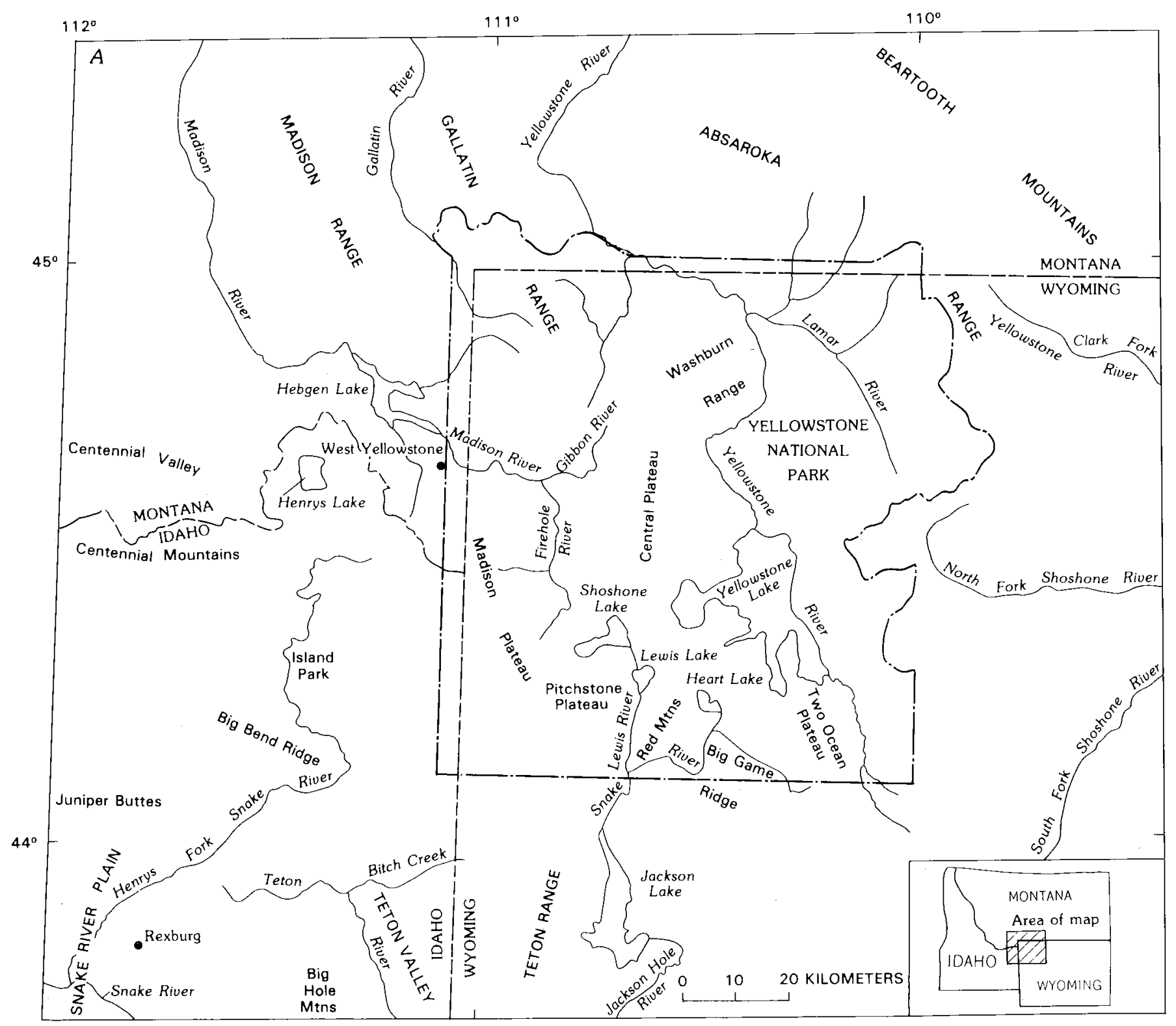

Figure 1.-Maps of Yellowstone National Park and vicinity. A, Topographic features, rivers, and lakes. $B$, The three Yellowstone calderas (I, II, and III), major fracture zones and faults, surrounding mountain ranges, and epicenters (small circles) of more than 1,500 earthquakes having Richter magnitudes between 1 and 6 (modified from
Christiansen, 1984). C, Index map of Yellowstone Park showing thirdcycle caldera rim, the ring-fracture zone, resurgent domes, Norris Geyser Basin, Norris-Mammoth Corridor, and distribution of known active and fossil hydrothermal systems (black; modified from Christiansen, 1984). 


\section{GLACIAL HISTORY}

The history of glaciation and related events in and near Norris Basin was reviewed by Richmond and Waldrop (1975) and revised by Pierce and others (1976) and Pierce (1979). At least three distinct Pleistocene glaciations or glacial stages were recognized by Richmond and Waldrop in the park. From oldest to youngest, they were called Sacagawea Ridge, Bull Lake, and Pinedale glacial stages, with local evidence for still older events.

Pierce and others (1976) and Pierce (1979) utilized obsidian-hydration dating techniques and correlations with marine stratigraphy to conclude that the Pinedale glacial climax near West Yellowstone occurred about 25,000 years B.P. and ended with abrupt deglaciation about 12,000 years B.P. End moraines, accepted by both Richmond and Pierce as occurring during the Bull Lake glacial stage, are much older than had been thought by Richmond; their obsidian-hydration ages range from about 130,000 to 155,000 years B.P. Thus, these Bull Lake deposits of West Yellowstone correlate with the Illinoian glaciation rather than with any stage of the younger Wisconsin glaciation.

These differences in interpretation of glacial ages have major consequences for unraveling the hydrothermal history of the park. Extensive, thick rhyolite flows approximately 127,000 years old were not present to block southward and westward flow of Bull Lake ice into the West Yellowstone region but could have caused extensive ice blocking in and south of Norris and Gibbon Basins as recently as about 90,000 years B.P. (indicated age of the Gibbon River flow) or later. Deposits mapped as Bull Lake kames by Richmond and Waldrop (1975) in Norris Basin and similar deposits in Elk Park and Gibbon Geyser Basins are clearly younger than and were confined by the Gibbon River flow. Thus, these kames are no more than $\sim 90,000$ years old and cannot be as old as Bull Lake glaciation. For similar reasons, we follow Muffler and others (1982) in assigning many kame deposits to the early Pinedale glacial stage rather than to the Bull Lake stage (as mapped by Richmond and Waldrop, 1975).

\section{HYDROTHERMAL ACTIVITY}

Norris Basin is a relatively small area with a complex history of thermal activity. The oldest preserved thermal record consists of stream sediments dominated by clastic quartz and hydrothermally cemented by chalcedony and adularia (hydrothermal K-feldspar) into very hard, tough rocks called chalcedony-cemented sandstone or hydrother-

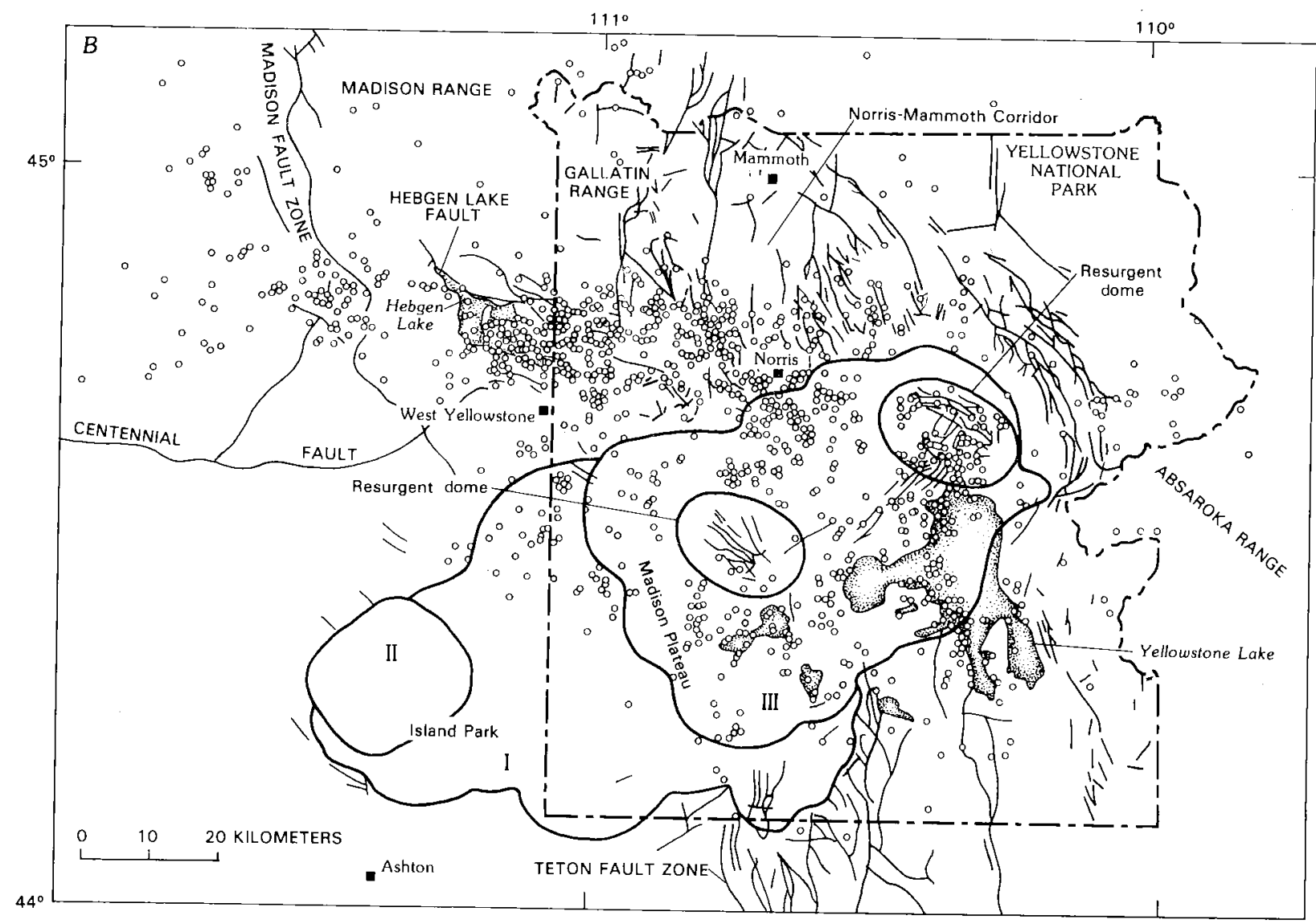

Figure 1.-Continued. 
mal quartzite (White and others, 1964). The clastic quartz was derived, at least in major part, from stream-abraded quartz phenocrysts during an old interglacial period when Lava Creek ash-flow tuff was the dominant bedrock of the surrounding area and rhyolite flows were rare or absent. These chalcedonized stream sediments are concluded to have been overlain by a siliceous hot-spring sinter, initially opaline but then chalcedonized in its lower part (from comparison with active and fossil sinter-depositing systems of the world). This hypothesized terrace, perhaps 10 to $>20 \mathrm{~m}$ thick, was completely stripped of its sinters by glacial abrasion, probably by early Pinedale glaciers. An even older Bull Lake interglacial hydrothermal event, again with no certain in situ sinter, is indicated by rare rounded pebbles of chalcedonic sinter locally incorporated in the hydrothermal quartzite.

Hydrothermal activity continued through early Pinedale glaciation when glaciers and meltwater runoff were blocked by the $\sim 90,000$-year-old Gibbon River lava flow. Geothermal heat caused local rapid melting of early Pinedale ice in Norris Basin; thus, the debris load was dumped as kame deposits on ice margins. Contemporaneously, the impeded drainage of meltwater maintained water saturation in kames and fractured ice to elevations of at least $2,375 \mathrm{~m}(7,800 \mathrm{ft})$. Convective circulation of hot water in the kames resulted in extensive

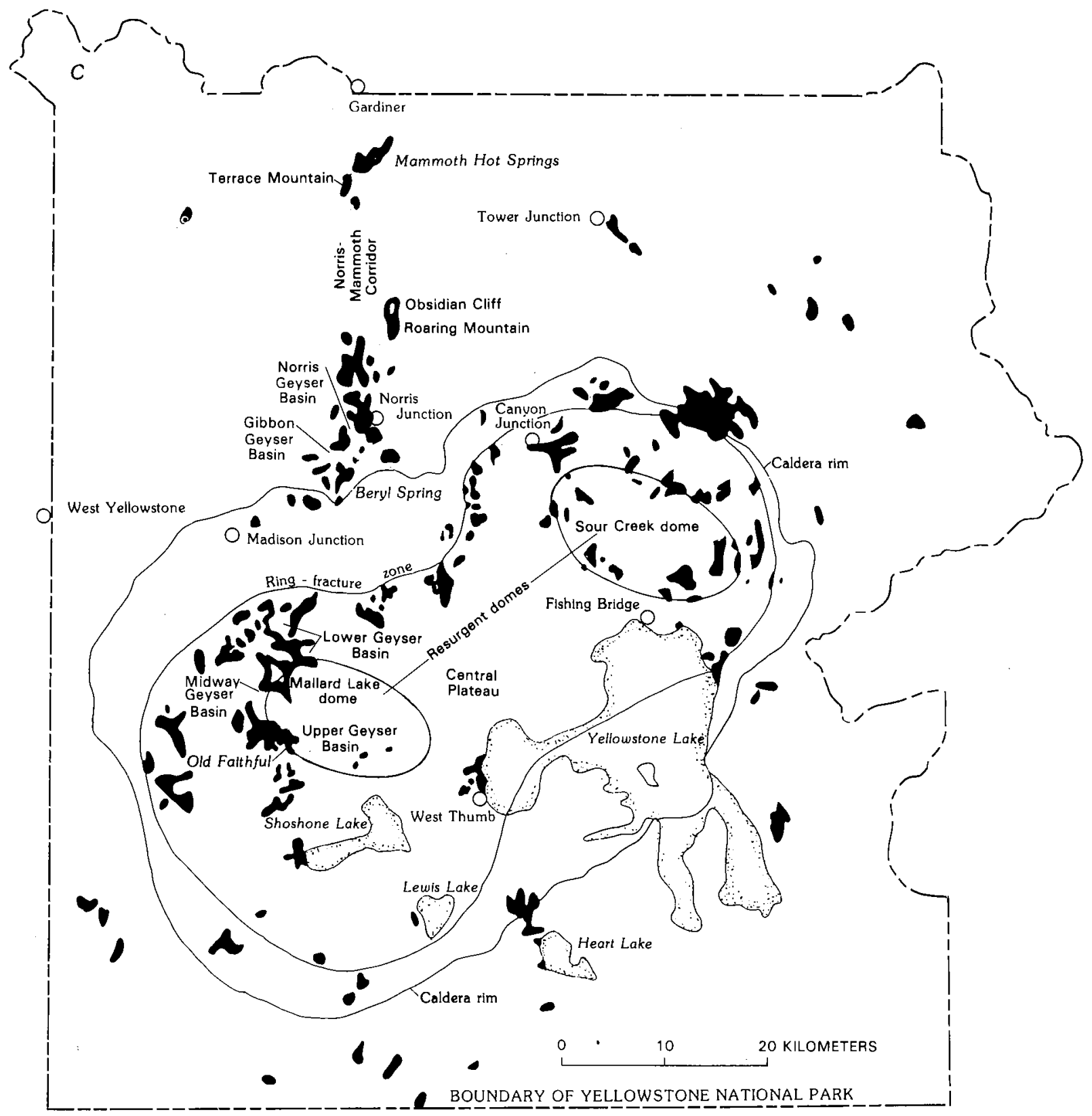

Figure 1:-Continued. 
TABLE 1.-Ages of volcanic rocks most closely associated with Norris Geyser Basin

[Generalized from Christiansen (in press, table 1)]

\begin{tabular}{|c|c|}
\hline Volcanic unit & $\begin{array}{c}\text { Approximate } \\
\text { age } \\
(\mathrm{m} \cdot \mathrm{y} \cdot \mathrm{B} \cdot \mathrm{P} .)\end{array}$ \\
\hline Huckleberry Ridge Tuff (first cycle)---- & 2.0 \\
\hline Mesa Falls Tuff (second cycle)-------- & 1.3 \\
\hline Lava Creek Tuff (third cycle) & \\
\hline $\left.\begin{array}{l}\text { Member } A \\
\text { Member } \mathrm{B}\end{array}\right\}$ & .63 \\
\hline $\begin{array}{l}\text { Plateau rhyolites. Central Plateau } \\
\text { member (from Yellowstone caldera) }\end{array}$ & \\
\hline Nez Perce Creek flow, Gibbon Canyon- & .16 \\
\hline Solfatara Plateau flow--_-..------ & .11 \\
\hline $\begin{array}{l}\text { Plateau rhyolites. Roaring Mountain } \\
\text { member (from Norris-Mammoth Corridor) }\end{array}$ & \\
\hline Crystal Spring flow------ & .08 \\
\hline Gibbon River flow, vent dome-------- & .09 \\
\hline Norris Dome (of this report)------- & .16 \\
\hline Obsidian Cliff flow---- & .18 \\
\hline 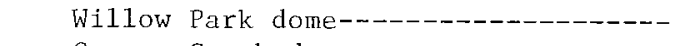 & .32 \\
\hline Cougar Creek dome------------- & .40 \\
\hline
\end{tabular}

reconstitution of clastic obsidian and pumice, thereby cementing the kames with amorphous opal but no other recognized hydrothermal mineral. Upflowing thermal water mixed with cold circulating meltwater; kame cementation temperatures probably were less than or close to $100{ }^{\circ} \mathrm{C}$.

After breaching of the Gibbon River lava dam, water levels in the upstream basins, including Norris, declined close to present ground levels. Hot springs then discharged on the basin floors and along kame margins while associated gases, including $\mathrm{H}_{2} \mathrm{~S}$, flowed upward through the still-porous and only moderately cemented kames. Atmospheric oxidation of $\mathrm{H}_{2} \mathrm{~S}$ still continues in many places, locally resulting in crystallization of native sulfur. However, $\mathrm{H}_{2} \mathrm{SO}_{4}$ is the dominant oxidation product that, in turn, reacts with potassium-bearing silicate rocks, forming widely dispersed alunite.

Subaerial hot-spring sinter was probably deposited locally during ice withdrawal between early and late Pinedale glacial stages, but the record is not clear. A late Pinedale readvancement of ice was probably short in duration, and its recession must have been unusually rapid. The related ground moraine is widespread on nonthermal areas but is remarkably scanty within Norris Basin, except for local till and uncemented kames on its south and west borders. Late Pinedale kame debris is generally uncemented, indicating either an absence of water saturation or a short duration of the thermal interval between advance and retreat.

After the last recession (or stagnation) of Pinedale ice from the Norris Basin area, thermal activity evidently evolved rapidly to conditions similar to that of the present time.

\section{ROGKS AND SEDIMENT OF NORRIS GEYSER BASIN}

Rocks older than the Lava Creek Tuff of the third cycle of the Yellowstone caldera ( $\sim 600,000$ years B.P.) are not exposed near Norris Basin.

\section{LAVA CREEK TUFF}

The lower member (A) of the Lava Creek Tuff was erupted from the western part of the huge double Yellowstone caldera (Christiansen, 1975, 1984); it does not crop out in Norris Basin but is exposed in the canyon of the upper Gibbon River near Virginia Cascades $6 \mathrm{~km}$ east-southeast of Norris and on both sides of the Gibbon River Rapids $3 \mathrm{~km}$ to the southwest. In surface outcrops, the lower member is generally brown and consists of devitrified, densely welded ash-flow tuff. Black vitrophyre and gray microspherulitic rocks are present at the base of the unit (not exposed near Norris Basin). Upper parts of member A, which extend downward from depths of $\sim 39.0 \mathrm{~m}$ in $\mathrm{Y}-9, \sim 23.8 \mathrm{~m}$ in Carnegie II (C-II), and $\sim 37.8$ $\mathrm{m}$ in Y-12 (pl. 1; fig. 2), are the only rocks from this lower member found at depth in these three research holes drilled in the basin. Some of the drill core from member A is brown, but bleaching from hydrothermal alteration is also very characteristic. Large phenocrysts of quartz and sanidine from 1 to $5 \mathrm{~mm}$ in diameter are abundant throughout the member. Below the upper contact of member A, Y-12 drill hole penetrated $294 \mathrm{~m}$ of partially welded tuff, with little obvious primary variation not related to superimposed hydrothermal effects. We have no reliable basis for estimating its local total thickness, because the vitrophyre and microspherulitic zones described by Christiansen (in press) were not encountered.

The upper member (B, pl. 1) consists of gray, brown, or pinkish-gray ash-flow tuff that is devitrified throughout and is generally densely welded except for a partially welded vapor-phase zone near its base. Lithic inclusions are locally abundant, and lenses of collapsed pumice are characteristic. Some lenses about $35 \mathrm{~m}$ above the base of member B in Y-9 drill hole are at least $15 \mathrm{~cm}$ long (fig. 3). Phenocrysts of quartz, sanidine, and sodic plagioclase are generally abundant, with sanidine commonly being the largest; opaque iron oxides, clinopyroxene, and fayalitic olivine are present as sparse phenocrysts in fresh rocks, but only hydrothermally altered relicts of these minerals were seen in the drill core. A thin basal zone of phenocryst-poor tuff grades downward from densely welded to partly welded tuff and is underlain by a thin, well-bedded, crystal-rich ash that may have been winnowed from air-fall tuff. 
Member A underlies all of Norris Basin and is commonly mantled by glacial and other deposits. Of these deposits, the thickest (at least $30 \mathrm{~m}$ thick) is the older Pinedale cemented kame deposits of Ragged Hills. Elsewhere, especially around the southeastern part of the basin, younger Pinedale till is present on the surface, but roadcuts and local outcrops on minor ridges indicate that the till is a thin veneer, generally less than $2 \mathrm{~m}$ thick, that lies on Lava Creek Tuff.

None of the younger rhyolite flows or domes discussed in previous sections crop out in Norris Basin, but the Norris Dome $(160,000$ years old, table 1$)$ lies immediately to the southeast of the area shown on plate 1. For further understanding of these rhyolites, refer to Christiansen (1975, in press).

\section{GEOCHEMISTRY OF THE COMMON SILICA MINERALS AND DIAGENESIS OF HOT-SPRING SINTERS}

An understanding of the geochemistry of the different silica minerals is essential for the following discussion of diagenetic changes that occur in siliceous hot-spring deposits (and comparable changes in siliceous cements of previously existing rocks and sediment).

All siliceous hot-spring sinter, defined as chemical precipitates of silica from water flowing on the ground surface (White and others, 1956, 1964), is first deposited as amorphous opal or silica gel in subaerial environments that favor rapid evaporation. Given sufficient time and temperatures above surface boiling (due to burial, increased water pressure, and thus higher permissible temperatures of coexisting water and steam), amorphous opal is converted to the next more stable (thus, less soluble) silica mineral, $\beta$-cristobalite (fig. 4). The complete sequence is: amorphous opal or silica gel $\rightarrow \beta$-cristobalite $\rightarrow \alpha$-cristobalite $\rightarrow$ chalcedony $\rightarrow$ quartz; euhedral quartz crystals normally line open cavities. This complete sequence exists at Steamboat Springs, Nevada, with increasing depth in GS-5 drill hole (White and others, 1956, 1964) and at Orakeikorako, New Zealand (D.E. White, unpublished data). Elsewhere, the well-crystallized $\alpha$-cristobalite (with many recognized X-ray peaks) is com-

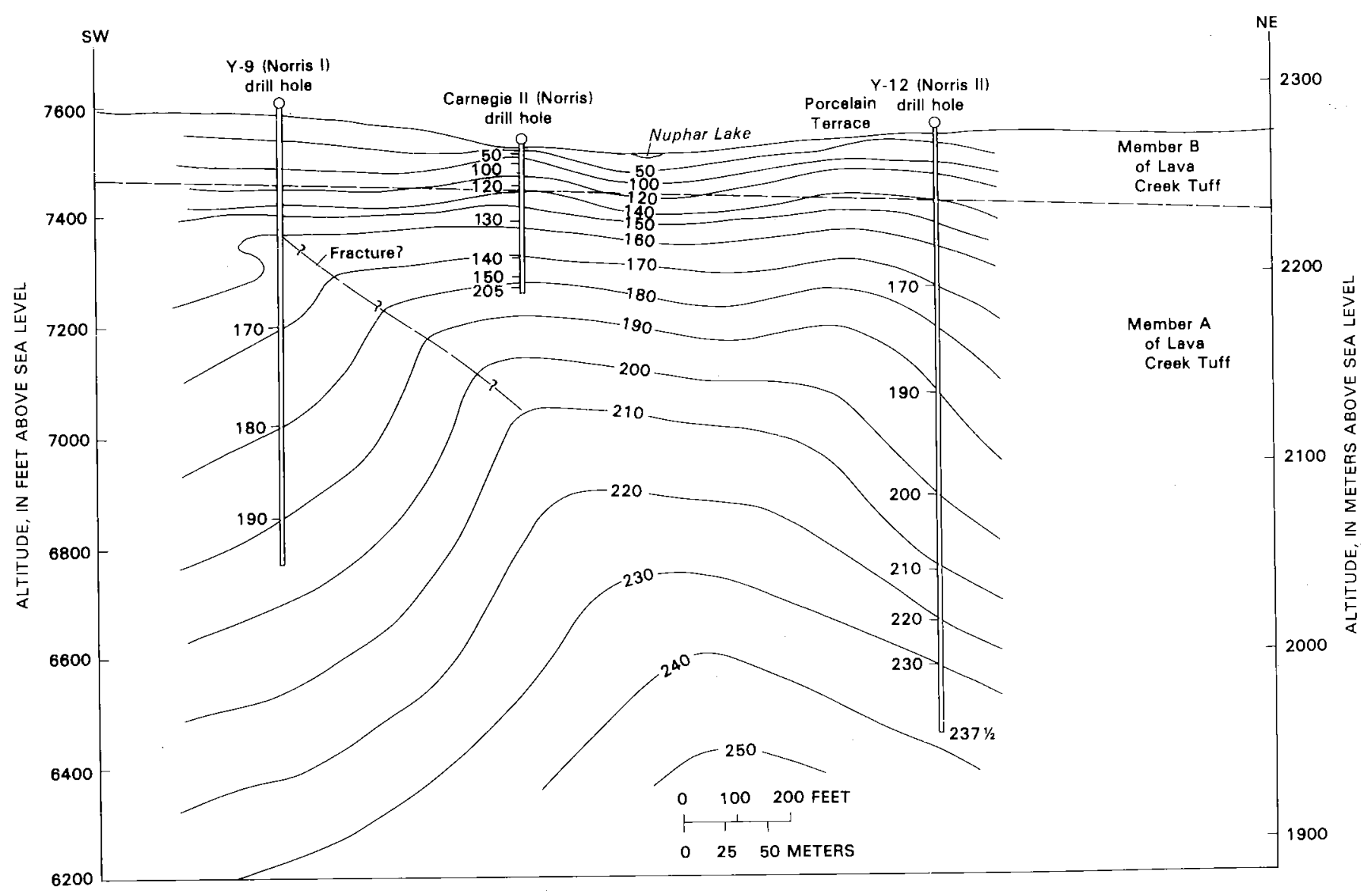

FiguRE 2.-Vertical section through Norris Basin drill holes, showing temperature contours (in degrees Celsius) from bottom-hole data as drilling progressed and a hypothesized fracture to explain interference between hole Y-9 and Carnegie II (modified from White and others, 1975 , p. 62). 
monly bypassed, with $\beta$-cristobalite (major peak near 4.10 to $4.11 \AA$ ) recrystallizing directly to chalcedony.

A similar diagenesis from amorphous opal of diatomite through evolving crystallinity of cristobalite and chalcedony occurs in marine siliceous shales (Hein and others, 1978; Murata and others, 1978), except that the "opal CT" of marine stratigraphers generally has a recognizable tridymite shoulder on the main cristobalite peak, but hydrothermal $\beta$-cristobalite normally lacks a tridymite shoulder. Therefore, we retain the name $\beta$-cristobalite. Differences in the marine chemical and physical environments-especially temperature, high pressure, and major content of magnesium-may be critical in affecting the diagenesis rate. Hein and others (1978) found that initiation of opal CT ( $\beta$-cristobalite) occurs at present temperatures of 35 to $51{ }^{\circ} \mathrm{C}$ in diatomite about 10 m.y. old.

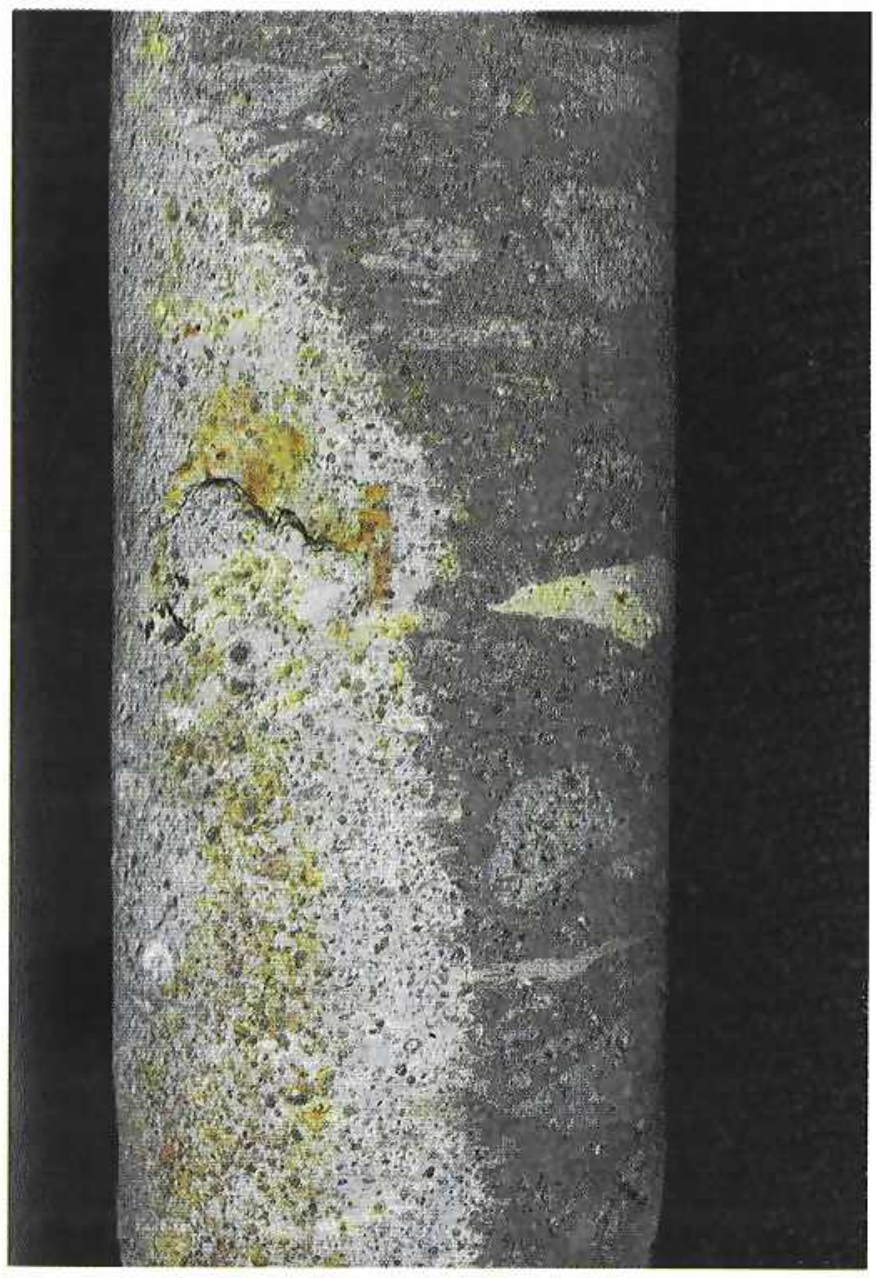

FIGURE 3.-Drill core about 3 inches in diameter from drill hole Y-9 (pl. 1, E5-NE); depth $3 \mathrm{~m}$ in basal part of member B, Lava Creek Tuff, showing large collapsed pumice lumps (white and light gray); hydrothermal bleaching and oxidation of pyrite were controlled by a vertical fracture. Photographed September 28, 1967.
Murata and others (1978) found similar relations in diatomaceous shale of California, except that solution and redeposition is indicated in the abrupt change from biogenic opal (amorphous opal) to disordered cristobalite ( $\beta$-cristobalite), and the gradual change to ordered cristobalite (our $\alpha$-cristobalite) occurs near a temperature of $48 \pm 8^{\circ} \mathrm{C}$ (from extent of fractionation of oxygen isotopes). The further conversion of ordered cristobalite to microquartz (chalcedony) occurs at an indicated temperature of $79 \pm 2{ }^{\circ} \mathrm{C}$. The magnesium content of sea water and the evolution of oceanic temperatures may account for some or all of the contrasts between nonmarine hydrothermal versus marine nonthermal environments.

Chalcedonic sinter probably always forms in nearly neutral to alkaline hot-spring systems. Acid systems do not form the copious thick surface deposits that seem essential for deep burial and increased hydrostatic pressures that permit temperatures much above surface boiling. Nearly neutral to high $\mathrm{pH}$ may also be essential in dissolving the less stable (more soluble) forms of $\mathrm{SiO}_{2}$ that reprecipitate as chalcedony and quartz.

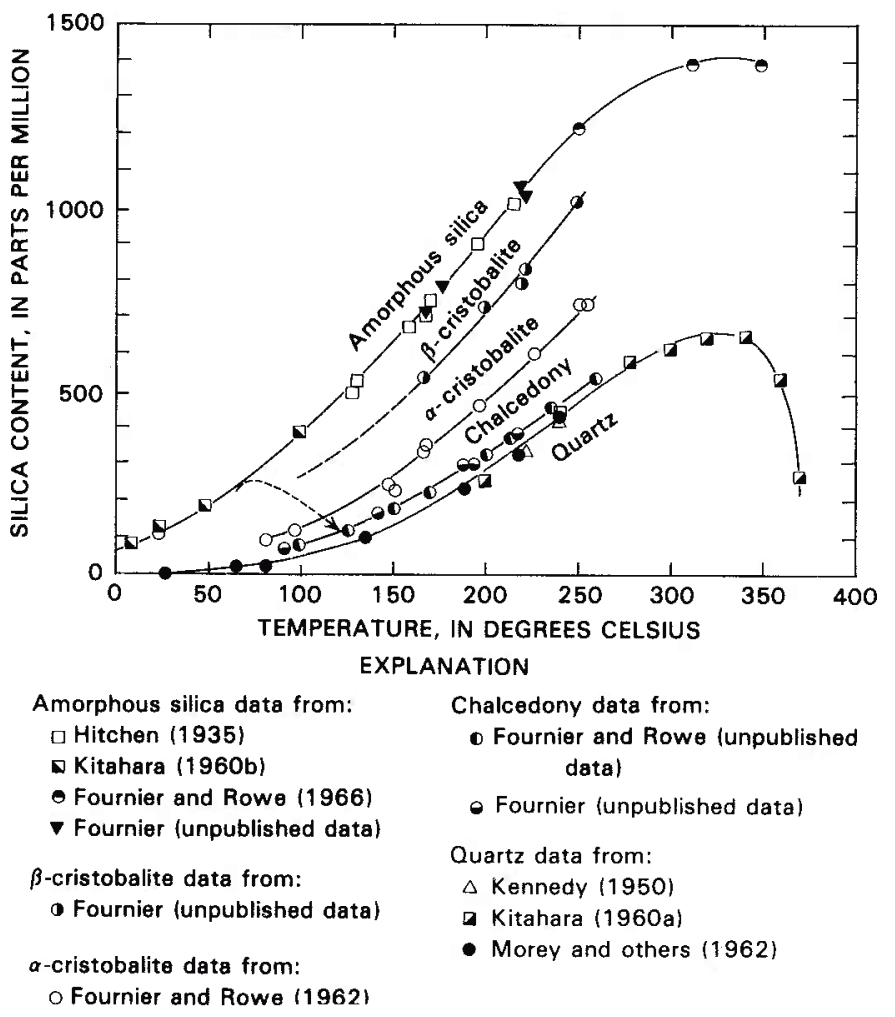

FIgure 4.-Solubilities of common silica minerals along two-phase curve of water and vapor (modified from Fournier, 1973). Dashed line shows $\beta$-cristobalite extending down to $100{ }^{\circ} \mathrm{C}$, and dotted line shows approximate trend observed in diagenetic evolution of opaline sinter in an active system as burial occurs. Trend is from amorphous opal $\rightarrow \beta$-cristobalite $\rightarrow$ chalcedonic sinter, commonly but not always bypassing $\alpha$-cristobalite. Actual diagenesis path depends on time versus temperature, not represented by a single line. 
Where a complete stratigraphic section is exposed, chalcedonic sinter is commonly but not always underlain by clastic sediments cemented by chalcedony; the abundance of clay minerals and other constituents may play a role in $\mathrm{SiO}_{2}$ diagenesis.

In a major thermal upflow zone, as in Carnegie-I (C-I) drill hole of Upper Geyser Basin (table 2), hydrothermal $\mathrm{K}$-feldspar exists with chalcedony in veins and pore fillings. With increasing horizontal distance from major upflow, K-feldspar disappears and, still farther out on discharge margins, cristobalite or even amorphous opal without K-feldspar may occur. In addition, the normal vertical diagenetic evolution of the silica minerals becomes more irregular, indicating complications other than simple progressive change downward in temperature and pressure. Much evidence indicates that sinter does not form within and directly beneath ice or cold water, although silica vein fillings may undergo a similar diagenetic sequence. Vein deposits have many characteristics that differ from true sinter (White and others, 1964). The initial hot-spring mineral deposits at the surface always seem to be amorphous $\mathrm{SiO}_{2}$, requiring deep subsurface temperatures of at least $180{ }^{\circ} \mathrm{C}$ (quartz solubility of about 250 ppm, residually enriched by vapor loss to a minimum of $300 \mathrm{ppm}$ of amorphous $\mathrm{SiO}_{2}$ ) for normal equilibration with quartz (fig. 4). With upflow and cooling, most of this silica remains in solution, because the kineties of silicamineral deposition is so sluggish (indicated qualitatively by the frequent agreement between the $\mathrm{SiO}_{2}$ geothermometer and bottom-hole measured temperatures, if near but not much above $180^{\circ} \mathrm{C}$ ). When discharged subaerially with rapid boiling, evaporation and or rapid cooling, as in a geyser eruption or on a hot-spring apron, the water precipitates amorphous $\mathrm{SiO}_{2}$. However, chalcedony and one or both of the cristobalites may be an initial vein mineral at intermediate temperatures; the evidence was not clear in Y-8 drill hole (Keith and others, 1978), where the stable silica minerals were chalcedony or cristobalite, but relict shrinkage cracks indicated initial deposition of a less dense (more hydrous) phase.

The time required for conversion of opaline sinter to cristobalitic and chalcedonic sinters is a time-temperature tradeoff. In general, burial of opaline sinter to depths of at least $10 \mathrm{~m}$ (where temperatures of coexisting water and steam are near $120{ }^{\circ} \mathrm{C}$ ) requires several thousands of years for conversion to chalcedonic sinter. We suspect

TABLE 2.-Minimum depths and temperatures of identified hydrothermal K-feldspar (adularia), chalcedony, and $\beta$-cristobalite in research drill holes, Yellowstone National Park

[Data from detailed studies by 'T E.C. Keith (holes 4, 7, 8,9,12,13, C-1, and C-II), Keith Bargar (holes 2, 3, 6, and 11), and Honda and Muffler (1970, hole 1); temperature interpolated from

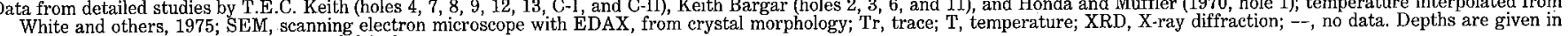
White and others, 1975; SEM, scanning electr
meters; temperatures are in degrees Celsius]

\begin{tabular}{|c|c|c|c|c|c|c|c|c|c|c|c|}
\hline \multirow[t]{4}{*}{ Drill hole } & \multicolumn{3}{|c|}{ Sinter $\left(\mathrm{SiO}_{2}\right.$ species $)$} & \multicolumn{8}{|c|}{ Vein minerals } \\
\hline & \multirow{3}{*}{$\begin{array}{l}\text { Maximum } \\
\text { depth }\end{array}$} & \multirow{3}{*}{ Type ${ }^{1}$} & \multirow{3}{*}{$\begin{array}{c}\mathrm{T} \\
\text { (at base } \\
\text { of } \\
\text { sinter) }\end{array}$} & \multicolumn{4}{|c|}{ Adularia } & \multicolumn{2}{|c|}{ Chalcedony } & \multicolumn{2}{|c|}{ B-Cristobalite } \\
\hline & & & & \multicolumn{2}{|c|}{$\begin{array}{l}\text { By microscope } \\
\text { and XRD } \\
\end{array}$} & \multirow{2}{*}{$\begin{array}{c}\text { SEM } \\
\begin{array}{l}\text { Observed } \\
\text { depth }\end{array}\end{array}$} & \multirow{2}{*}{ 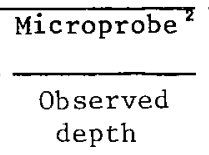 } & \multirow{2}{*}{$\begin{array}{l}\text { Minimum } \\
\text { depth }\end{array}$} & \multirow{2}{*}{$\mathrm{T}$} & \multirow{2}{*}{$\begin{array}{l}\text { Minimum } \\
\text { depth }\end{array}$} & \multirow{2}{*}{$\mathrm{T}$} \\
\hline & & & & $\begin{array}{l}\text { Minimum } \\
\text { depth }\end{array}$ & $\mathrm{T}$ & & & & & & \\
\hline$C-I$ & $\sim 2.2$ & opa1 & $\sim 50$ & 13 & $\sim 110$ & -- & -- & 13.0 & -- & -- & -- \\
\hline $\mathrm{Y}-1$ & 3.7 & opa1 & $\sim 49$ & 30.5 & 134 & -- & -- & -- & -- & -- & -- \\
\hline \multirow[t]{2}{*}{$Y-2$} & $\sim 7$ & opal & $\sim 82$ & 57.8 & $\sim 150$ & $83.7,127.6$ & $66.1,75.6$ & 8.4 & $\sim 85$ & 0.8 & $\sim 10$ \\
\hline & 10.2 & $\beta$-crist. & $\sim 90$ & -- & -- & 157.2 & -- & -- & -- & -- & -- \\
\hline$Y-3$ & None & -- & -- & -- & -- & -- & -- & 18.9 & $\sim 110$ & 10.7 & $\sim 70$ \\
\hline$Y-4$ & None & -- & -- & -- & -- & -- & $\therefore--$ & -- & -- & -- & -- \\
\hline $\mathrm{Y}-5$ & None & -- & -- & -- & -- & -- & $\because--$ & 17.7 & -- & -- & -- \\
\hline$Y-6$ & None & -- & -- & 23.2 & $\sim 85$ & $24.7,30.9$ & 25.1 & 25.0 & $\sim 65$ & 21.9 & $\sim 50$ \\
\hline$Y-7$ & 1.8 & opa1 & $\sim 45$ & -- & -- & -- & -- & $\sim 6.0$ & $\sim 45$ & -- & -- \\
\hline$Y-8$ & 1.5 & opal & 70 & 24.8 & 105 & $\operatorname{Tr} 4.5,6.4$ & -- & 4.0 & - & $\sim 4-7$ & $\sim 105$ \\
\hline$Y-9$ & None & -- & -- & None & -- & -- & -- & 147.8 & $\sim 178$ & 41.1 & $\sim 125$ \\
\hline $\mathrm{Y}-10$ & None & -- & -- & None & -- & -- & -- & None & -- & None & -- \\
\hline$Y-11$ & None & -- & -- & None & -- & -- & -- & 59.4 & $\sim 150$ & 2.2 & 20 \\
\hline $\mathrm{Y}-12$ & None & -- & -- & (?) 137.2 & 190 & -- & -- & 65.2 & $\sim 163$ & 10.7 & $\sim 85$ \\
\hline$Y-13$ & 2.3 & opa 1 & 52 & 41.8 & 154 & $\operatorname{Tr} 7.9$ & 57.7 & 2.3 & 52 & -- & -- \\
\hline$C-I I$ & None & -- & -- & None & -- & -- & -- & 23.8 & $\sim 115$ & 34.4 & $\sim 125$ \\
\hline
\end{tabular}

${ }^{1}$ Dominant $\mathrm{SiO}_{2}$ mineral, amorphous opal or $\beta$-cristobalite.

${ }^{2}$ Adularia with 98 to $99.2 / 3$ percent K-feldspar (data from M.H. Beeson, U.S. Geological Survey). 
that the $\mathrm{pH}$ of through-going water is also important, but we are not aware of any thick sinter deposits formed at a $\mathrm{pH}$ below about 6 .

Based on this reasoning, short interglacial periods are not as favorable for generation of chalcedonic sinter as are long interglacial periods with sustained activity. Unfortunately, silica-mineral diagenesis has too many unknowns to be subject yet to quantitative analysis.

The single approach available to us is the study of measured thicknesses of sinter in the 15 research drill holes in the park (table 2). Six holes were collared in sinter, but all U.S. Geological Survey holes were located to provide wellhead stability rather than to obtain the best field data on thickness and type of sinter. The maximum age of post-Pinedale basal sinters is $\sim 12,000$ years B.P., when late Pinedale glaciers are believed to have melted from the areas, permitting subaerial discharge of sinterdepositing springs. The single exception is Y-2 drill hole, where alternating sinter and travertine are present to a depth of $\sim 10 \mathrm{~m}$, and sinter also had been deposited on the margins of surrounding rhyolite flows to elevations of $\sim 30 \mathrm{~m}$ above the local wellhead. These latter sinter deposits are interpreted as having formed from sinterdepositing ice-margin hot springs of late Pinedale age, but other sinter and travertine had been deposited as much as $10 \mathrm{~m}$ below the present ground surface, perhaps during an inter-Pinedale retreat. This older inter-Pinedale sinter could have been subjected to temperatures as high as $145^{\circ} \mathrm{C} \mathrm{(30} \mathrm{m}$ of water pressure above reference curve A on figure 17 of White and others, 1975). Thus, 15,000 years at temperatures perhaps as high as $145{ }^{\circ} \mathrm{C}$ were adequate to convert amorphous opal to $\beta$-cristobalite.

One other Yellowstone drill hole, Y-13, has amorphous sinter that shows incipient conversion to $\beta$-cristobalite. Postglacial amorphous opal seems to be developing an intermediate $\beta$-cristobalite stage at a present depth of 2.3 $\mathrm{m}$ and a present temperature near $52{ }^{\circ} \mathrm{C}$ in $\sim 12,000$ years. We do not know whether either of these areas had continuous activity during all post-Pinedale time or whether present temperatures are the maximum attained, but the evidence seems clear that 12,000 years at temperatures from $50{ }^{\circ} \mathrm{C}$ to as high as $70^{\circ} \mathrm{C}$ is not sufficient to convert amorphous opal to $\beta$-cristobalite.

\section{HYDROTHERMAL QUARTZITE}

Chalcedony-cemented sandstone (sach on plate 1), also called hydrothermal quartzite, is present in the western part of Norris Basin southwest of Tantalus Creek (pl. 1, block $\mathrm{C} 2$ and westernmost $\mathrm{C} 3$, hereafter denoted as C3-W). This unit was initially mapped as a local chalcedonized facies of cemented older Pinedale kames but is now interpreted as unrelated pre-Pinedale stream deposits. No good outcrops exist, but distribution of the unit was mapped from subrounded and angular blocks or boulders of an extremely hard, tough rock that consists mainly of clastic phenocrysts of quartz and sanidine cemented by chalcedony and locally with adularia (hydrothermal K-feldspar near the pure potassium end member). The boulders are commonly $\sim 0.5$ to $2 \mathrm{~m}$ in diameter and are strewn haphazardly over a nearly horizontal erosion surface cut on these rocks. Similar rocks are not known elsewhere in the basin except as rare small fragments in younger Pinedale glacial deposits. We conclude that quartzite underlies the boulder-strewn area. The basal contact, judging from distribution of these boulders and the underlying Lava Creek Tuff, is crudely horizontal, with the quartzite being about $6 \mathrm{~m}$ thick.

The quartzite contains abundant angular to subrounded grains of quartz, commonly as much as 2 to $3 \mathrm{~mm}$ in diameter in the coarser grained laminae. Some grains show subhedral crystal faces of quartz and were originally phenocrysts similar in size to the abundant quartz phenocrysts of the underlying Lava Creek Tuff. Small abraded quartz grains are abundant in the matrix and are dominant in fine-grained laminae. Some clastic fragments are sanidine, and others are devitrified rhyolite with some phenocrysts or segments of phenocrysts. Most lithic fragments are too small to determine their origin, but some fragments are large enough to be identified tentatively as Lava Creek Tuff. Rare clasts as much as $3 \mathrm{~cm}$ long seem to be stream-rounded pebbles of chalcedonic sinter; if this is correct, a still older episode of hydrothermal activity is indicated, probably pre-Bull Lake $(>150,000$ years B.P.). All clastic grains are cemented dominantly by chalcedony, which is commonly translucent and slightly darker than the clastic quartz. In overall appearance most of the rocks are light to dark gray, but some are iron stained in shades of yellow, brown, and red. Because of the toughness of the matrix, fractures cut across clastic grains rather than around them. For this reason, these rocks are a special kind of quartzite rather than sandstone. In relative age and origin, these rocks are strikingly similar to the Pliocene or early Pleistocene hydrothermal quartzite of Steamboat Springs, Nevada (White and others, 1964, p. B28-B29).

In thin section, the cement is seen to consist mainly of chalcedony of varied grain size; euhedral quartz crystals as much as $1 \mathrm{~mm}$ long line the rare unfilled cavities. Many grains of clastic quartz show narrow overgrowths of hydrothermal quartz in optical continuity. Hydrothermal $\mathrm{K}$-feldspar (adularia) is abundant in some rocks, locally even as abundant as chalcedony. In thin section, much adularia is not easily distinguished from clastic sanidine, but in some rocks the K-feldspar has the tabular, wedgeshaped euhedral forms of adularia rather than sanidine. 
Where these forms are abundant, the diagnostic X-ray characteristics of nearly pure monoclinic K-feldspar support its hydrothermal origin, as distinct from the Na-bearing sanidine of volcanic phenocrysts and hightemperature vapor-phase deposits. Some broken or rounded clastic fragments of sanidine crystals show overgrowths of adularia in optical continuity, but with slightly lower indices of refraction. These overgrowths tend to have euhedral crystal faces, suggesting that many adularia crystals may also have unrecognized cores of clastic sanidine. Pyrite is a sporadic hydrothermal mineral that yields, when oxidized, the iron staining mentioned above. Some fresh quartzite contains no pyrite.

We interpret this quartzite as a resistant erosion remnant or core of an old high-temperature convection system, the upper part of which was first deposited as opaline sinter, later chalcedonized, and then entirely removed by erosion (see subsection "Pre-Pinedale Chalcedonic Sinter"). Thus, the quartzite indicates an early major episode, not otherwise evident, in the history of thermal activity in Norris Basin.

If the rounded chalcedonic clasts in the quartzite are correctly identified as chalcedonic sinter, an additional cycle of still older hydrothermal activity in or near Norris Basin is indicated. Chalcedony and hydrothermal K-feldspar are not known to form at the surface of any hot-spring system but have been found at depth in many high-temperature spring systems (table 2 ). The most common near-surface silica mineral of such systems is amorphous opal. In summary, given sufficient time and especially at temperatures well above surface boiling, initial amorphous opal is slowly converted to cristobalite and eventually to chalcedony. In hot-spring areas, the most common way for temperatures to increase above atmospheric boiling is through burial under younger hotspring sinters. As depth of burial increases, hydrostatic pressure on a given stratum thereby increasing the permissible temperatures of boiling.

The minimum depths where adularia and chalcedony have been recognized in core samples from research drill holes in Yellowstone's thermal areas are listed in table 2 . The shallowest depth of recognized adularia is useful in assessing a reasonable depth of cover removed by erosion since the roots of the old system (pl. 1, C2) were active. Present temperatures at these depths, as interpolated from data obtained as drilling progressed (White and others, 1975), are also listed. Core samples from four drill holes that were also examined by a scanning electron microscope contain tiny euhedral crystals that have the characteristic wedge shapes of adularia at shallower depths than detected using a polarizing microscope. Moreover, vein adularia is an indicator of an upflow zone of a system where boiling, loss of $\mathrm{CO}_{2}$, and increase in $\mathrm{pH}$ favors precipitation of K-feldspar (Hemley, 1959;
Browne, 1971). The low temperature observed for adularia in drill hole $\mathrm{Y}-6$ (table $2, \sim 85^{\circ} \mathrm{C}$ at $-23.2 \mathrm{~m}$ ) is misleading. The upper $21 \mathrm{~m}$ penetrated by this hole consist of uncemented and unaltered sand and gravel, in contrast to altered rhyolite at greater depths. We suspect that the adularia is early Pinedale in age and precipitated at higher temperatures than existed after glacial stripping of its original cover by younger Pinedale ice. If this is so, all present temperatures in Y-6 are too low, having adjusted to flow of cold water in the overlying permeable uncemented gravels (White and others, 1975, p. 25-27).

The abundance of adularia and the great dominance of chalcedony among the possible hydrothermal silica minerals probably indicate depths of cover considerably above the minimum depth of microscope-detected K-feldspar (table 2). Complete conversion of opaline sinter to chalcedonic sinter (comparable to the chalcedony matrix of the quartzite) is not known to occur at depths shallower than 25 m (GS-5 drill hole, Steamboat Springs, Nevada), where present temperatures are $\sim 130^{\circ} \mathrm{C}$ (White and others, 1964, p. B15; White, 1968, p. C63). A reasonable assumption, based on drill-hole data from both Yellowstone and Steamboat Springs, is that the present level of erosion cut on the quartzite in the area shown on block C2 of plate 1 originally had a cover of 15 to 25 m more than now. This missing cover was probably opaline sinter near the ground surface at that time, cristobalitic sinter at middle depths, and dominantly chalcedonic sinter and quartzite in its lower part.

In early mapping, the quartzite was first interpreted as early Pinedale kame deposits (present terminology) that had been subjected to more intense local hydrothermal action than other cemented kames. However, the following evidence indicates that the quartzite is older than and unrelated to any Pinedale or older kames. (1) The clasts of the original sediment prior to cementation are generally well sqrted, with many rounded to subrounded grains deposited in an environment much different from that of the kames. (2) Most clasts of the original sediment consist of quartz and sanidine, probably derived from abundant phenocrysts of these minerals in the underlying Lava Creek Tuff. Transport was by local streams rather than by glaciers, and no local source of aphyric rhyolite or obsidian was yet available, in contrast to the debris of all Pinedale kame deposits. (3) Although the contact between quartzite and adjacent opal-cemented kames is not exposed, the absence of gradations in float favors a nongradational contact, probably a disconformity separating rocks of strongly contrasting hardness and age. (4) One sample of quartzite has opal-cemented sandstone adhering in sharp contact on one side. This sandstone is typical of the older Pinedale kame deposits in having abundant small black granules of undevitrified obsidian, as well as clasts of quartz, sanidine, and 
devitrified volcanic rocks with abundant opal cement. Sanidine and $\beta$-cristobalite, detected by whole-rock X-ray diffraction of the opal-cemented sandstone, are probably from devitrified clasts of rhyolite flows. X-ray diffractograms of this sandstone are typical of the early Pinedale kame deposits except for slightly more abundant quartz and notable alunite. The debris probably settled downward as a clastic dike in fractured chalcedonized quartzite; conditions after emplacement were not hot enough or sustained long enough to devitrify the obsidian granules or to precipitate chalcedony or adularia in the sandstone matrix.

The above-described relations indicate a major hiatus between formation of the quartzite and deposition of the early Pinedale kame deposits. The hypothesized sequence of events deciphered from this partial record are: (1) Arkosic sandstone was deposited by a local stream draining terrane dominated by Lava Creek Tuff, with little other available debris. The stream was not supplied by glaciers but was interglacial (Sangoman?). (2) Hot springs became active, depositing opaline sinter on arkosic sandstone at some level above the present erosion surface. Contemporaneously, rising high-silica thermal waters were depositing amorphous silica in pore spaces in the arkose. (3) Interglacial hydrothermal activity continued, perhaps for thousands of years, forming a sinter terrace eventually to a level $15 \mathrm{~m}$ or more above present ground level. Temperatures in surface vents were near $93^{\circ} \mathrm{C}$ (surface boiling), but in upflow channels at depths of 15 to $25 \mathrm{~m}$ they were near $125^{\circ} \mathrm{C}$ (permitted by increased depth of water and consequent hydrostatic pressure, with less heat loss by boiling). (4) At middle depths in the sinter terrace, initial amorphous opaline sinter was being converted to $\beta$-cristobalite, while basal sinter layers were evolving to chalcedonic sinter (White and others, 1956; White and others, 1964). Contemporaneous with these diagenetic changes in sinter, initial opal cement in underlying arkosic sand was chalcedonized. In principal upflow channels boiling resulted in selective loss of $\mathrm{CO}_{2}$ to vapor, thereby increasing $\mathrm{pH}$ and locally depositing adularia. (5) Deposition of sinter from this system eventually ceased, either because of self-sealing or from engulfment by early Pinedale glaciers from the east. Note that opaline sinter forms at the surface where high-silica waters can evaporate rapidly; subaqueous deposition in rivers or lakes is unknown. The supply and depth of ice were probably great, and glacial erosion was sustained for a sufficient time to remove all chalcedonic sinter from the areas shown on blocks $\mathrm{C} 2$ and $\mathrm{C} 3$ of plate 1 , and some underlying quartzite. This task was not easy or rapid because chalcedonic sinter and chalcedonized quartzite are extremely tough and highly resistant to mechanical and chemical erosion (as diamond drillers found to their great regret at Steamboat Springs, Nevada; White, 1968).

\section{PRE-PINEDALE CHALCEDONIC SINTER}

Cobbles of chalcedonic sinter have been recognized as glacial erratics in at least 10 areas of present and former hydrothermal activity in the park, but source outcrops of such sinter that could supply the cobbles are exceedingly rare. In general, original sources were either eroded completely by glacial scour or are concealed under younger deposits.

The distribution of erratics of chalcedonic sinter in Norris Basin is puzzling and seemingly contradictory. Cobbles of such sinter are relatively abundant on the present surface of uncemented younger Pinedale kame deposits and are believed to have been selectively enriched from these younger kames because of their very great hardness, toughness, and resistance to chemical weathering. Similar resistant cobbles also are on the surface of other older Pinedale cemented kames, especially in ravines cut into these kames and within $200 \mathrm{~m}$ of the contact between the two kames of different ages, as in the areas shown on blocks E2, F2, and F3 of plate 1. Richmond and Waldrop (1975) first interpreted the cobbles as components of the older cemented kames. However, intense search of these kames, where exposed in the walls of gulleys, has failed to reveal any sinter cobbles that are clearly cemented in place. This negative evidence suggests that a supply of chalcedonic sinter was available during younger Pinedale glaciation but was not available for the older Pinedale cemented kames.

The single outcrop of chalcedonic sinter exposed in Norris Basin is deep in the vent of North Hydrophane Spring (pl. 1, G3-SE; table 3), where $>0.3 \mathrm{~m}$ of chalcedonic sinter was exposed above boiling water level prior to the rise in water levels in 1982; total thickness is unknown. Only $0.3 \mathrm{~m}$ of acid-leached sandstone similar to older Pinedale cemented kame sediments separate the chalcedonic sinter from postglacial opaline and cristobalitic sinter.

Elsewhere in the park, the most accessible outcrops of chalcedonic sinter are along both sides of a deep roadcut leading to Artists Point, about $1.5 \mathrm{~km}$ east of the Lower Falls of the Yellowstone River. Sinter is interbedded with early postcaldera sediments in the roadcut, but massive sinter is common at higher levels adjacent to the cut. These sinters are believed to be the oldest hot-spring deposits in the park (much older than late Pleistocene glaciations), as agreed upon by both Richmond (1976) and Christiansen (in press); however, these authors disagree on specific age assignments.

The largest concentration of chalcedonic sinter that might be correlative with, but not the specific source of, Norris chalcedonic cobbles exists as large angular chaotic blocks $\sim 1.5 \mathrm{~km}$ west of Elk Park and $\sim 2.5 \mathrm{~km}$ southwest of Norris Basin, in an area mistakenly shown as Holocene 
alluvium by Christiansen (1975). L.J.P. Muffler (oral commun., 1985), in later unpublished mapping, correctly identified these blocks, some of which are more than 1 $m$ in length and width and have an average thickness of $\sim 0.3 \mathrm{~m}$. Nearly random bedding attitudes in individual blocks convinced Muffler that this sinter did not constitute a mappable outcrop. We agree that no blocks are strictly in place, but consider them to be derived from underlying sinter, having become locally disturbed and redistributed by glacial plucking and frost action. About 0.3 $\mathrm{km}$ farther southwest of the large chaotic blocks, cemented and well-bedded kame deposits (Christiansen, 1975) contain rounded and subrounded cobbles of chalcedonic sinter. The cemented kames are partly bleached and contain abundant alunite; they seem identical to the cemented older Pinedale kames of Ragged Hills, Norris Basin, except for their abundant chalcedonic sinter cobbles. Other similar kames with chalcedonic cobbles also are in and around Sylvan Springs in western Gibbon Geyser Basin $3 \mathrm{~km}$ southwest of the cobblecontaining cemented kames described above. All these cemented kames are probably correlative and related to

TABLE 3.-Rocks exposed in vent of North Hydrophane Spring [Area shown on plate 1, southeast part of block G3]

\begin{tabular}{|c|c|}
\hline Thickness & Description \\
\hline $1.6 \mathrm{~m}$ & $\begin{array}{l}\text { Opaline sinter at top, forming a broad } \\
\text { rim around the spring vent; dominantly } \\
\beta \text {-cristobalite with minor clastic quartz. }\end{array}$ \\
\hline $.5 \mathrm{~m}$ & $\begin{array}{l}\text { Opaline sinter of the inner vent; } \beta \text {-cris- } \\
\text { tobalite, with a sharper X-ray peak than } \\
\text { overlying sinter on the broad rim; base } \\
\text { of this zone shows stronger quartz peaks } \\
\text { and narrower, sharper } \beta \text {-cristobalite } \\
\text { peaks. }\end{array}$ \\
\hline $.3 \mathrm{~m}$ & $\begin{array}{l}\text { Acid-leached cemented sandstone, relict } \\
\text { from older Pinedale cemented kames; this } \\
\text { thin bed not distinguished on plate } 1 ; \\
\text { has common clastic quartz, abundant } \alpha- \\
\text { cristobalite, and distinct tridymite } \\
\text { X-ray peaks characteristic of many de- } \\
\text { vitrified rhyolites; perlitic obsidian } \\
\text { is common and alunite less common; } \\
\text { partly acid-leached but not devitrified. }\end{array}$ \\
\hline$>.3 \mathrm{~m}$ & $\begin{array}{l}\text { Top of chalcedonic sinter; probably youn- } \\
\text { gest pre-Pinedale interglacial in age; } \\
\text { dominantly quartz and chalcedony, with } \\
\text { minor } \beta \text {-cristobalite (but no } \alpha \text {-cristo- } \\
\text { balite or amorphous opal). Base of } \\
\text { exposed sinter is entirely chalcedonic. } \\
\text { Underlying rocks concealed by boiling } \\
\text { water. Relations obscured when Hydro- } \\
\text { phane Springs became reactivated in } \\
1982 \text { (see subsection "Hydrophane } \\
\text { Springs"). }\end{array}$ \\
\hline
\end{tabular}

early Pinedale glaciers, ice-dammed by the Gibbon River flow. The principal difference is the abundance of chalcedonic cobbles as cemented clastic constituents in the Elk Park and Gibbon Meadows occurrences, in contrast to their scarcity or absence in the Norris cemented kames. Pre-Pinedale interglacial sinter of Elk Park probably supplied all or most of the abundant sinter cobbles in the southwestern kames but is not a reasonable source for the Norris Basin erratics because of required transport directions. Interglacial chalcedonic sinter probably also existed in Norris Basin but, for reasons not yet clearly understood, did not supply chalcedonic cobbles to early Pinedale kames (or were transported westward, out of the basin). Direction of flow of the younger Pinedale glaciers was approximately S. $40^{\circ} \mathrm{W}$., judging from the distribution of the highly characteristic erratics of chalcedony-cemented quartzite in the area shown on block B3 of plate 1. This direction of ice flow suggests that a concealed source of pre-Pinedale chalcedonic sinter may still exist under One Hundred Spring Plain.

\section{OLDER PINEDALE GEMENTED KAMES}

Thick clastic deposits underlie Ragged Hills on the southwest rim of Norris Basin, and similar deposits are present near the center of the mapped area shown on block E4 of plate 1 . These deposits are crudely stratified, showing great local variations in attitude. Chaotic bedding in young stream deposits standing high above surrounding terrane is characteristic of ice-contact deposits (Richmond and Waldrop, 1975). Individual beds range in thickness from a few millimeters to several meters. Clasts are generally from $<1 \mathrm{~mm}$ to $1 \mathrm{~cm}$, but local clasts in the highest of the eastern Ragged Hills (pl. 1, E3, E4) are as much as $30 \mathrm{~cm}$ in diameter. Pebble- and cobble-sized clasts are largely confined to these eastern hills.

The original sediments are now moderately indurated and cemented by opal, but still retain high porosity. None of these kames is nearly as hard and tough as the previously described hydrothermal quartzite and chalcedonic sinter. In color, the kames range from nearly white through a variety of grays, browns, and yellows. The lightcolored and iron-stained varieties are all hydrothermally altered and still have great variations in heat flow, with pronounced effects on vegetation patterns. In detail, especially in the coarser grained beds, the rocks are mottled, with color differences between individual clasts. The freshest rocks have black to gray clasts of glassy obsidian. Commonly the larger obsidian clasts are extensively perlitized and gray, but small clasts $(\sim 1 \mathrm{~mm})$ are less perliţic and dark gray to black. In almost all cemented kames, obsidian granules that can be distinguished by hand lens have perlitic shells and undevitrified (although perhaps hydrated) cores. Clasts that are dull, porcelainic, 
and fine grained are generally devitrified volcanic rocks that have sparse phenocrysts and range in color from white to light gray and tan. A few clasts are porphyritic rhyolite with conspicuous large quartz phenocrysts and leached cavities, probably relict from feldspars.

Cobbles of chalcedonic sinter (map unit sich erratics of plate 1) are relatively abundant in steep-walled gulleys incised in the older Pinedale kame deposits, especially in the areas shown on blocks E2, E3, and F3 of plate 1 . These sinter cobbles are relatively abundant as far as 100 $m$ from younger Pinedale kames; this relation first suggested derivation from the older Pinedale kames. However, careful search has failed to reveal a single cobble or small clast of chalcedonic sinter in the cemented kames. Instead, most cobbles are concentrated in the bottoms of gullies. Leaching by $\mathrm{H}_{2} \mathrm{SO}_{4}$ (generated from oxidation of $\mathrm{H}_{2} \mathrm{~S}$ ) is characteristic of much of the area now underlain by the older Pinedale kames. The described relations are best explained by destruction of less resistant clasts of the younger Pinedale deposits that originally extended over these chemically active areas, thus resulting in residual concentration of the resistant erratics of chalcedonic sinter.

Cemented kames in the northern and northwestern margins of Norris Basin have clasts that are somewhat finer grained than those of Ragged Hills; few clasts are as much as 1 to $4 \mathrm{~cm}$ in diameter, and 1 to $2 \mathrm{~mm}$ is the maximum in most beds.

Dark glassy grains of obsidian are common in much of the older Pinedale cemented kames. In thin section, most obsidian is seen to have perlitic cracks and thus is hydrated but not devitrified. Some devitrified volcanic clasts have a few small phenocrysts in a fine-grained groundmass. Clastic quartz is present but not abundant, whereas the cementing mineral is dominantly amorphous opal. Although zeolites are characteristic of the older Pinedale kame deposits of Lower Basin (Muffler and others, 1982), no zeolite has yet been identified in the Norris kames. If ever present, they have been destroyed in the present relatively acid environment.

The older Pinedale kames have been systematically studied by whole-rock X-ray diffraction techniques; the samples were ground, mounted, and run using standardized procedures that permitted qualitative comparisons of mineral abundances, convertible to semiquantitative major-mineral abundances if desired. These techniques are useful in making relative comparisons of fine-grained minerals that are exceedingly difficult to quantify in thin section. The relative abundances of quartz, $\alpha$-cristobalite, $\beta$-cristobalite, tridymite, amorphous opal (or obsidian, not easily distinguished from opal by X-ray diffraction), K-feldspar (commonly distinguishing between sanidine and adularia), kaolinite, montmorillonite, and alunite are especially useful. Diffractograms of older cemented kames are characterized by common but not abundant quartz, generally abundant $\alpha$-cristobalite, no detected $\beta$-cristobalite, surprisingly abundant tridymite (determinable by whole-rock X-ray diffraction only when quartz and K-feldspar do not overwhelm its most characteristic peaks), and relatively minor K-feldspar. Alunite (best distinguished by its $18^{\circ} 2 \Theta$ peak) is common to abundant in most older kames, especially in Ragged Hills where bleaching and iron-staining are common. Alunite is also present in the $0.3-\mathrm{m}$ sandstone bed tentatively identified as a thin remnant of the older cemented Pinedale kame (see table 3). Alunite was first suspected as an original clastic constituent but is absent in the least bleached medium-gray rocks with black obsidian granules, thus indicating local superimposed hydrothermal alteration. $\mathrm{H}_{2} \mathrm{~S}$ is relatively abundant in gases now being discharged from Norris Basin. Near the surface, the $\mathrm{H}_{2} \mathrm{~S}$ is oxidized to elemental sulfur and $\mathrm{SO}_{3}$, which then dissolves in water to form sulfate, as required for alunite.

Broad areas of cemented kames are characterized by anomalously high total heat flow and by partly barren ground that is too hot and acid for normal pine trees to grow (fig. 5). These features indicate active generation of $\mathrm{H}_{2} \mathrm{SO}_{4}$ from oxidizing $\mathrm{H}_{2} \mathrm{~S}$ in many present-day localities that lack flowing springs.

The thick cemented kames in southwestern Norris Basin have the chaotic cross stratification, lateral discontinuity of bedding, and slump structures typical of mound kames deposited adjacent to glacial ice. The common association of kame deposits with active thermal areas in Yellowstone Park is viewed as very strong evidence that these areas were thermally active when overridden by ice. Local rapid melting of debris-laden ice resulted in dumping of rock debris at the ice margins. If nearby basins were filled with ice, meltwater accumulated in local lakes bounded by ice walls.

Cementation of the older Pinedale kames by opal probably occurred while the kame sediments were watersaturated. Hot high-silica water discharging from the Norris hydrothermal system could then convect within the porous mass. Present Norris thermal waters are among the highest in silica content of all Yellowstone waters. Even though diluted by some meltwater, mixtures would still have been high enough in silica to precipitate opaline cement at low to moderate temperatures (fig. 4).

The cemented kame deposits of Lower Geyser Basin, also correlated with older Pinedale glaciation (Muffler and others, 1982, who differ with the earlier views of Waldrop and Pierce, 1975), contrast with the Norris deposits in having abundant coarse clasts, commonly exceeding 20 or $30 \mathrm{~cm}$ in diameter. Obsidian clasts are generally perlitic and some small clasts are completely leached, leaving voids. Many voids contain thin septa of opal that filled fractures in obsidian, with later selective dissolution of 
the glass. Also, in addition to opal, mordenite and other zeolites are abundant as pore minerals.

As previously stated, zeolites have been looked for in the Norris deposits but have not been found. If originally present, they have been completely leached in the postglacial acid environment that characterizes this area. Alternatively, we suggest that zeolites did not form in the Norris kames because the $\mathrm{pH}$ of most Norris thermal waters is too low, relative to the Firehole River geyser basins.

The dominant sources of debris in the older Pinedale kame deposits were probably rhyolite and obsidian-rich flows southeast of the basin. Most clasts consist of obsidian and devitrified rhyolite. Some obsidian clasts are pumiceous, but most obsidian granules are nonpumiceous and black. The abundant lithic fragments are mainly devitrified rhyolite. Some clasts contain small phenocrysts of quartz, but most are aphyric, with lineations of micro- crysts presumably controlled by original flow structure. Some clasts show clusters of radiating crystals indicative of spherulites. No clasts from the Lava Creek ash-flow tuffs were recognized, but some larger clastic quartz grains could have such an origin. The abundance of small clasts in the older Pinedale kames may indicate derivation from rhyolitic obsidian flows erupted into or under glaciers, with consequent rapid chilling and thermal-stress cracking, thereby comminuting most available debris.

\section{YOUNGER PINEDALE GLACIAL DEPOSITS}

According to Richmond and Waldrop (1975), the Pinedale icecap (herein considered younger Pinedale) flowed northwest into Norris Junction quadrangle from the basin of Yellowstone Lake. At a late stage this icecap was joined by a glacier flowing south into Norris Basin

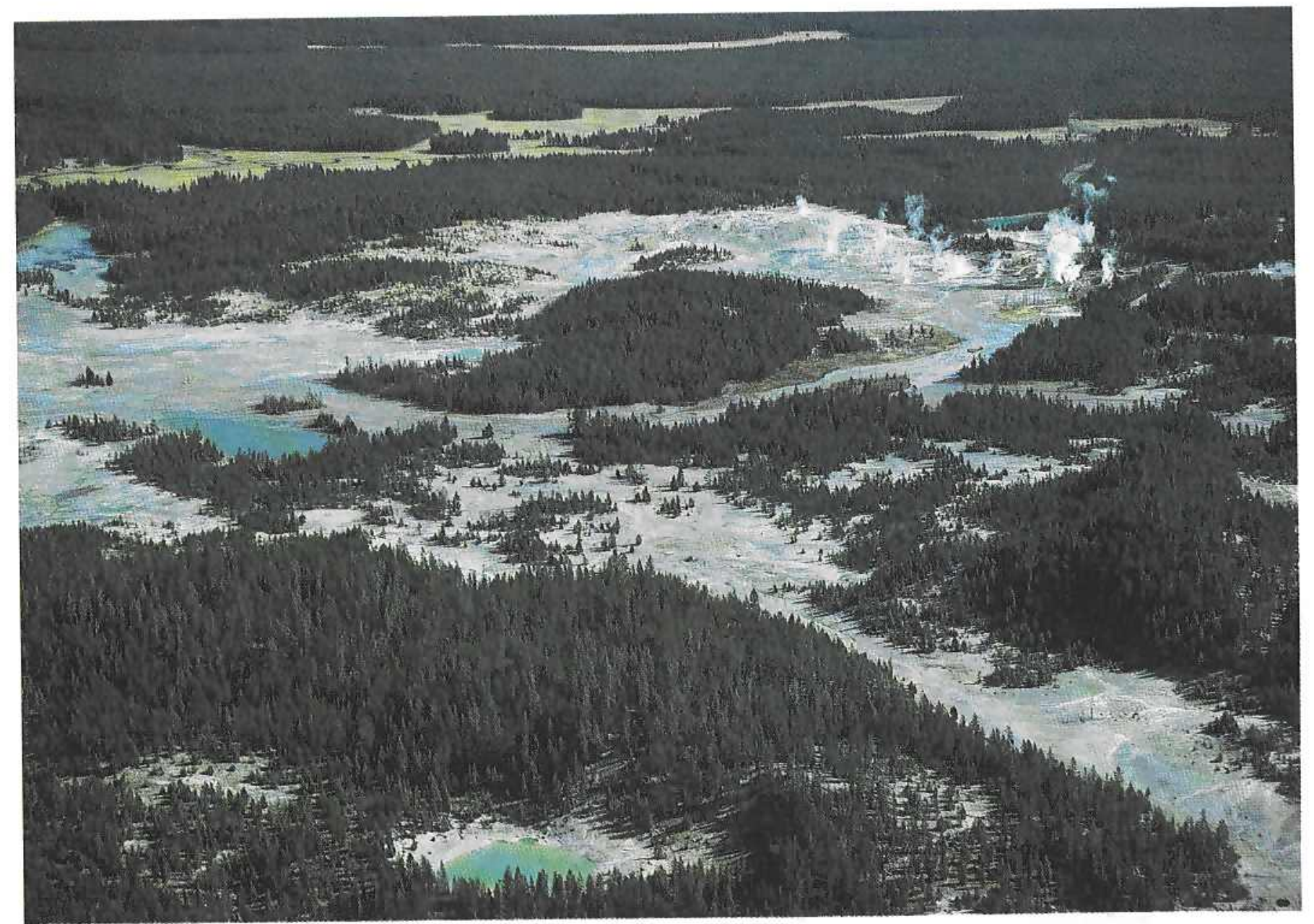

Figure 5.-Aerial view eastward over explosion crater (pl, 1, D2). Blue-green color of crater is typical of acid-sulfate waters. Prominent northeaststriking structure (lower right to upper left) trends through The Reservoir (blue water, pl. 1, C3), a possible but less likely explosion crater. Hydrothermally altered areas (white to gray) contrast with nonthermal meadows (straw yellow, in distance). Photographed October $18,1967$. 
from the Gallatin Range and adjacent uplands to the east. Ice from the two sources, after merging near Norris Basin, moved south and southwest, distributing erratics as high as $\sim 2,530 \mathrm{~m}$ on Gibbon Hill, thus indicating a depth of ice of at least $240 \mathrm{~m}$ over Norris Basin at the time of maximum development. Extension of Pierce's $(1979$, pl. 1) maximum younger Pinedale ice contours over Norris Basin yields a considerably thicker estimate of $\sim 2,300 \mathrm{ft}(\sim 700 \mathrm{~m})$ of ice.

\section{KAME DEPOSITS}

Uncemented glacial deposits, mainly on the southwestern margin of Norris Basin, are mapped as younger Pinedale kames (pk on plate 1) even though Richmond and Waldrop (1975) included them with Pinedale till. These deposits are largely adjacent to and southwest of the thick cemented kame deposits of Ragged Hills, herein called older Pinedale.

The younger Pinedale kames consist of uncemented sands and gravels with rounded to subrounded cobbles and boulders as much as $20 \mathrm{~cm}$ in diameter. Most of the debris is rhyolitic, but some is from other sources. Clasts of basalt, andesite, quartzite, and intrusive rocks from the Gallatin Range and Mt. Holmes were recognized by Richmond and Waldrop (1975).

In the mapping of these deposits around Norris Basin, special attention was given to the distribution of erratics of chalcedonic sinter (sich), hydrothermal quartzite (sach), and to a lesser extent, glassy obsidian cobbles (obs) to provide evidence of local ice-flow directions and possible locations of concealed hydrothermal deposits. The bedrock quartzite is mainly in the areas shown in blocks C2 and westernmost C3 of plate 1. Thus, the distribution of quartzite erratics in younger Pinedale kames (pl. 1, D2, E2) provides narrow limits on permissible late-stage iceflow directions over Norris Basin, ranging from due south to $\mathrm{S} .30^{\circ} \mathrm{W}$. from its bedrock source area.

Erratics of chalcedonic sinter are more widely distributed than hydrothermal quartzite; the two distributions coincide in part, but a few sinter erratics lie as much as $300 \mathrm{~m}$ off the quartzite trend and at least two cobbles (pl. 1, C5-SW and D6-NE) must come from other source areas.

Erratics of glassy black obsidian, in part of arrowhead quality, are also a minor constituent of younger Pinedale kames. Richmond and Waldrop (1975) considered Obsidian Cliffs, $\sim 10 \mathrm{~km}$ to the north, as their probable source, indicating southward flow of younger Pinedale ice. However, similar obsidian also is present on the eastern slopes of Norris Dome about $4 \mathrm{~km}$ southeast of Norris Basin, which is the more probable source. The same obsidian supplied the samples dated at 160,000 years B.P. (table 1).
TILL

Debris incorporated in younger Pinedale ice and deposited during final melting without redistribution by water is mapped as till. Roadcuts around the southeastern margin of the basin and other local cuts and trenches indicate that this till is normally no thicker than $1 \mathrm{~m}$ and on topographic highs is usually $\sim 0.5 \mathrm{~m}$ thick. However, till may be thicker in topographic lows where manmade cuts are not available for observation.

Much of the area mapped as till (pl. 1) is probably underlain at shallow depth by Lava Creek Tuff. This interpretation is supported by the roadcuts and trenches previously mentioned and also by local outcrops of tuff along ridges, as mapped in the areas shown on blocks F5 and $\mathrm{F} 6$ of plate 1. Many other small outcrops of tuff surrounded by till could have been similarly identified but did not justify the effort.

\section{OUTWASH SANDS AND GRAVELS}

Sediments deposited by outwash streams from latestage Pinedale glaciers are present around the north rim of Norris Basin. These sediments rise from the central basin (pl. 1, B4) to the north on a rather uniform slope that projects about $7 \mathrm{~m}$ above present Gibbon River (immediately north of the area shown on plate 1). Farther upstream to the east, Gibbon River meanders over meadows 3 to $4 \mathrm{~km}$ wide, with no evidence of comparable sands and gravels. These sediments are interpreted as very late stage low-level kames, deposited when ice still occupied the present river channel north and east of Norris Basin; the main basin itself was then free of ice because of hydrothermal melting. Tantalus Creek, the present main outlet of Norris Basin, joins the Gibbon River several hundred meters west of the area shown on plate 1 , evidently providing ice-free drainage for the outwash streams discussed above.

After outwash sediments of the areas shown on blocks $\mathrm{A} 4, \mathrm{~A} 5$, and $\mathrm{A} 6$ of plate 1 were deposited, they were then entrenched by continuing meltwater flow, which ceased after the cutting of a 3-m-deep channel on the common boundary between the areas shown on blocks A5 and A6. Deeper entrenchment temporarily continued $100 \mathrm{~m}$ farther to the east (block A6), as well as along present Realgar Creek (block A4), where direction of its drainage is reversed from its late Pinedale flow to the south. The outwash sediments consist of gravel and sand in the areas shown on blocks A5 and A6 but are somewhat finer grained to the west and south. Whole-rock X-ray diffractograms of these uncemented sediments show less clastic quartz, tridymite, and glass, about equal $\alpha$-cristobalite, but more sanidine than the early Pinedale kames. 


\section{GEMENTED YOUNGER PINEDALE DEPOSITS}

Hydrothermally cemented younger Pinedale till is rare in Norris Basin, especially in comparison to the extensively cemented early Pinedale kames. Local cementation was recognized along the eastern discharge stream of Steamboat Geyser, and outwash sands and gravels are cemented locally in the northern part of the basin, but most younger Pinedale deposits lack even incipient cementation. Similar contrasts in cementation between deposits correlated with these two Pinedale glacial stages were recognized in the kames of Porcupine Hills of Lower Basin, where earlystage deposits are well cemented but are unconformably overlain by uncemented late-stage Pinedale kame deposits (Muffler and others, 1982). In these hills the contrast is explained by thorough self-sealing of upflow channels after the early kames were cemented; abundant high-silica waters were no longer available at high levels to cement the younger Pinedale deposits. Such an explanation is consistent with present-day low rates of discharge from nearby springs and the extensive self-sealing recognized in Y-13, drilled between the two western Porcupine Hills (White and others, 1975; T.E.C. Keith, written commun., 1979).

Little discharge of thermal water now occurs around the southwest, west, and northwest fringes of Norris Basin where early Pinedale kames were cemented, suggesting that former discharge channels of high-silica waters were also self-sealed here. Present-day springs and geysers of highest discharge and temperature generally also have the highest silica contents (table 4). Such waters now occur in the eastern parts of the basin, especially in a broad arc around the till-mantled bedrock ridge in the area shown on block E5 of plate 1 . With post-Pinedale discharge of water and heat now so high, why are late Pinedale kames and till so rare in this broad arc, and why are late Pinedale deposits outside of this active arc not cemented? Possibly the activity became localized or rejuvenated in this active arc after late Pinedale glaciation. $\mathrm{A}$ second and favored explanation assumes that late Pinedale glaciation was relatively short; during an intense climax, ice was supplied faster to Norris Basin than the very high heat supply could melt; debris resulting from melting was largely swept away by ice and water to the basin margin. Rapid wasting and withdrawal of ice then occurred, so that circulation of thermal water in watersaturated deposits was not sustained, in contrast to that of the earlier Pinedale environment. This explanation assumes a short duration and rapid wasting of late Pinedale glaciers, consistent with evidence obtained from surficial geologic studies in the Norris Junction quadrangle (Richmond and Waldrop, 1975; Waldrop and Pierce, 1975; Richmond, 1976; Pierce, 1979).

\section{HYDROTHERMAL EXPLOSION BRECCIA}

A feature mapped as a hydrothermal explosion crater is present in the western part of Norris Basin near the common join of blocks D1 and E1 (see also fig. 5). This feature was included as a possible explosion crater by Muffler and others (1971, p. 733), but the evidence they provided was not conclusive and still is not. However, an explosive origin is more satisfactory to us than alternative explanations.

Cemented older Pinedale kames crop out around the southeast rim of the depression, presumably revealed by slumping of eruption breccia. The kame deposits are believed to overlie Lava Creek Tuff at shallow depth because tuff is present immediately to the west and southwest of the crater. Strata of cemented kame are chaotically bedded, with large local variations in strike and dip.

From rim to rim, the topographic feature is about 120 $\mathrm{m}$ long and $90 \mathrm{~m}$ wide, slightly elongate north-south. Disregarding the shallow central pond, the topographic closure is about $5 \mathrm{~m}$. The feature has a craterlike shape with relatively steep inner walls bounded by gentle outward-sloping surfaces. Material mapped as eruption breccia contains some angular or subrounded blocks of cemented older Pinedale kame, but the dominant material consists of angular fragments and blocks of Lava Creek Tuff. The blocks of cemented kame are not resistant enough to form sharp-sided angular blocks, such as the chalcedony-cemented eruption debris of Lower Basin and the Mary Bay explosion breccias (Muffler and others, 1971; D.E. White, unpublished data).

Erupted blocks of cemented kame may also have been more abundant in the original explosion breccia, but disintegration after ejection was rapid because of selective weathering and frost action on the slightly cemented material.

A well-defined debris ring bounds the crater on its north, west, and southwest sides. A few fragments of probable eruption debris lie on till of the gently sloping rim southeast of the depression, but the quantity is small. Its scarcity was the major deterrent in classifying this feature as a definite explosion crater by Muffler and others (1971). Posteruption slumping of the oversteepened southeast wall of the crater may explain these relations.

An arcuate mound containing many blocks of Lava Creek Tuff and less abundant cemented kame lies about $15 \mathrm{~m}$ south of the inner depression and is interpreted as a partial debris ring from a minor late-stage explosion after the main crater had formed.

Does any other origin satisfy these described features better than a hydrothermal explosion? A kettle produced 
by melting of an isolated mass of stagnant glacial ice is unlikely because surrounding material consists largely of kame sediments deposited locally as a result of excess geothermal heat supply. Also, thermal activity that cemented the kames probably would have melted buried ice while stream gravels were still being supplied, thereby filling any volume of melting ice. A kettle is typically a "hole" in a nearly flat surface that is surrounded by glacial stream deposits and is not normally surrounded by a constructional cone rising above surrounding ground.

Localized acid leaching accompanied by collapse is an even less satisfactory explanation. Many centers of acid leaching related to near-surface oxididation of $\mathrm{H}_{2} \mathrm{~S}$ occur in ground underlain by cemented older Pinedale kames, especially in the Ragged Hills. Most small topographic basins have open drainage on one side, but a few are undrained depressions with closure of as much as $2 \mathrm{~m}$. Evidence of active acid leaching, as well as vapor emissions, characterizes the borders of most of these small basins, and their rims typically consist of porous, bleached relicts of cemented kame rather than mixed debris of Lava Creek Tuff and cemented kame that characterize the large western depression.

TABLE 4.-Chemical compositions of principal water types occurring in and near Norris Geyser Basin

[Compositions are in parts per million. Data in parentheses from other samples and analysts]

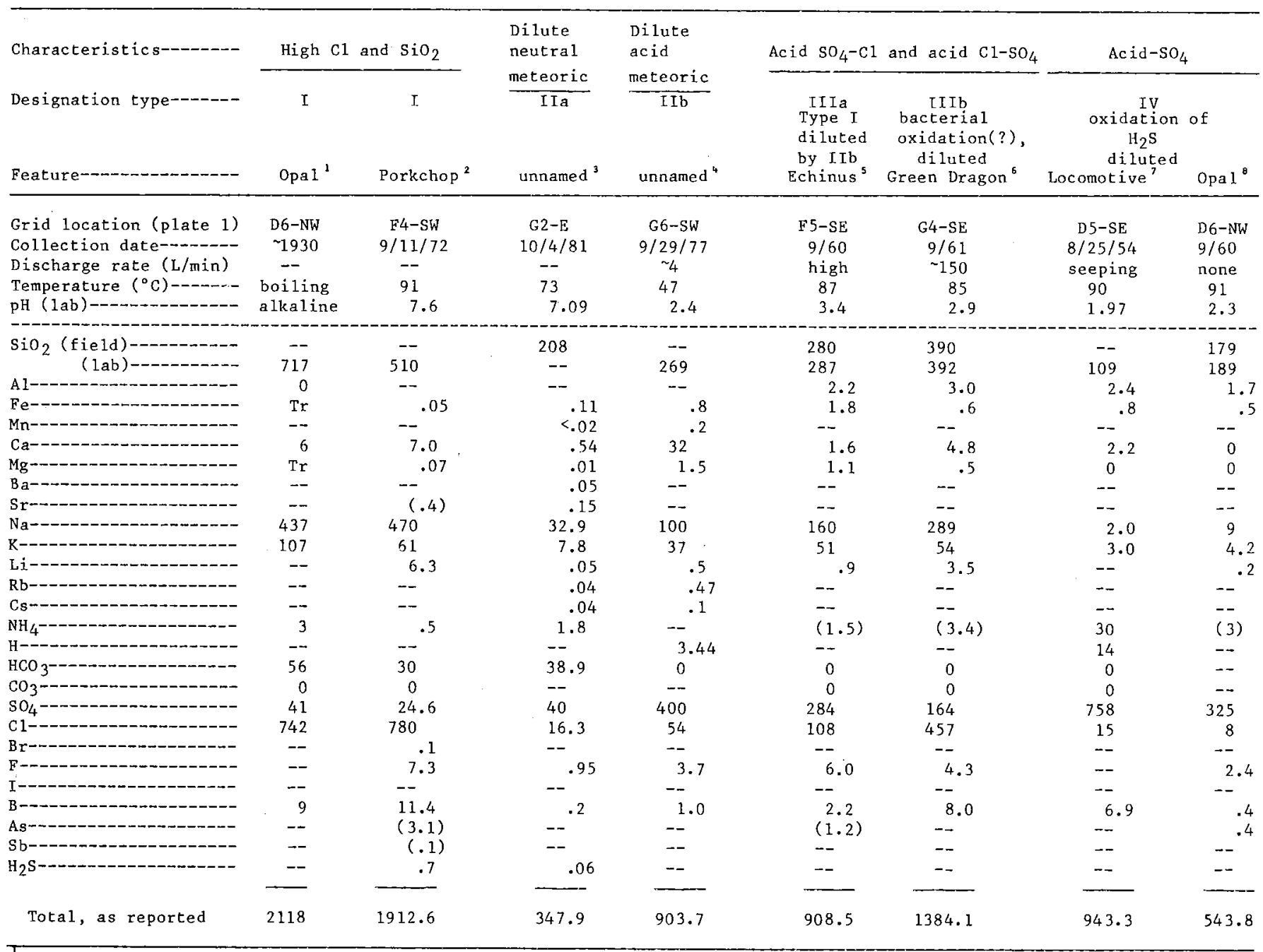

Tllen and Day (1935)

${ }^{2}$ Thompson and others (1975)

Sample YJ-81-5; not previously pub1ished; collected and analyzed by J.M. Thompson, U.S. Geologica1 Survey, 1981

5Thompon and Yadav (1979, samples F-7709 and F-77129)

${ }_{6}^{5}$ Collected September 1960; Rowe and others (1973, p. 12)

Rowe and others (1973)

White and others (1963, p. 46)

Rowe and others (1973, p. 14) 


\section{HOLOCENE SINTER DEPOSITS}

The distribution of postglacial hot-spring sinter is shown as unit si on plate 1 . Sinter is concentrated largely in Porcelain Basin, Porcelain Terrace, Back Basin, and the branches of Tantalus Creek. All springs and geysers high in temperature, discharge, $\mathrm{pH}$, and silica content are in areas underlain by sinter. Thick sinter might have been expected but in most low-lying places actual thickness is commonly $<1 \mathrm{~m}$. Rates of deposition are fast near a few springs that have high discharge rates, have neutral to slightly alkaline $\mathrm{pH}$, and have the other characteristics specified above. An outstanding example is near the south base of Porcelain Terrace (pl. 1, D5, D6; figs. 6, 7) between Opal Springs and Feisty Geyser, where many changes have been observed, commonly involving rapid deposition of sinter.

Sinter has also formed rapidly but typically for brief periods from several springs near the south end of the common join of the area shown on blocks D4 and D5, from Opalescent Spring (pl. 1, C5-NW), from Cistern Spring southwest of Steamboat Geyser from 1966 to the present time (fig. 8), from Coral Spring in 1965 and 1966 (pl. 1, G4-NW; fig. 9), with discharge then ceasing (fig. 10), and no evidence for flow since then, and from Porkchop Geyser (pl. 1, F4-SW; figs. 11, 12, 13) from time to time. These sites of rapid deposition commonly involve water that is opalescent from polymerized colloidal silica at existing temperatures (White and others, 1956).

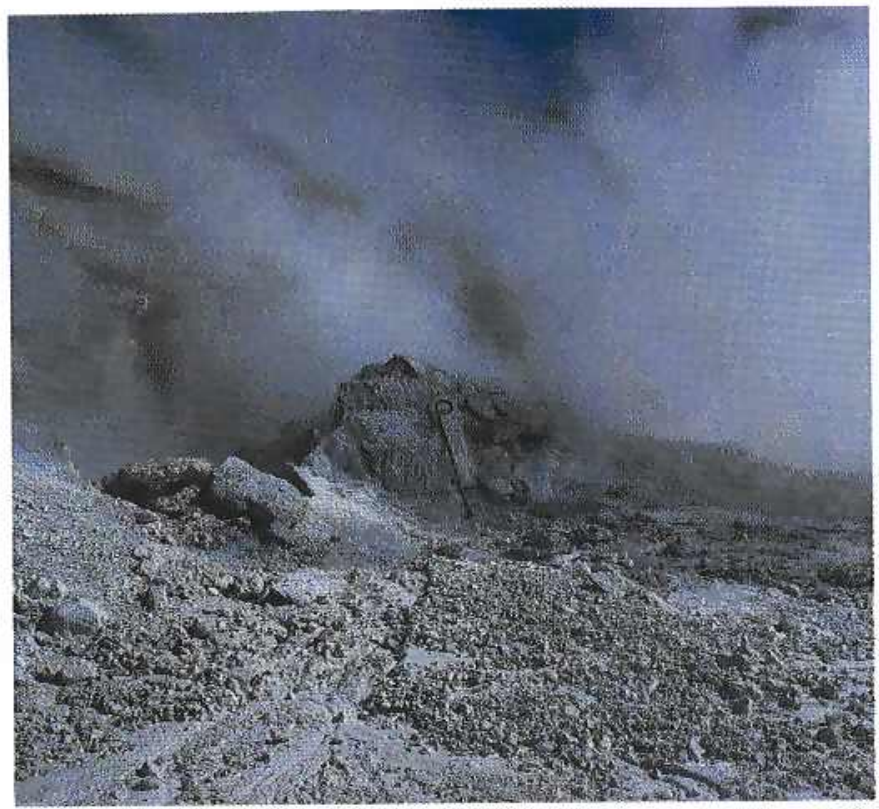

FIGURE 6.-Vents and eruption debris at south base of Porcelain Terrace (pl. 1, D5-NE). Steam is from small-scale hydrothermal eruption of September 9,1971 . Note cane in center for scale.
In contrast to these few areas of rapid deposition, most of Norris Basin is notable for its scarcity of sinter, especially considering the very high contents of $\mathrm{SiO}_{2}$ in most spring waters. For example, much of the southern part of the area shown in block D5 (pl. 1) is underlain by Lava Creek Tuff without a sinter cover. Major vents and

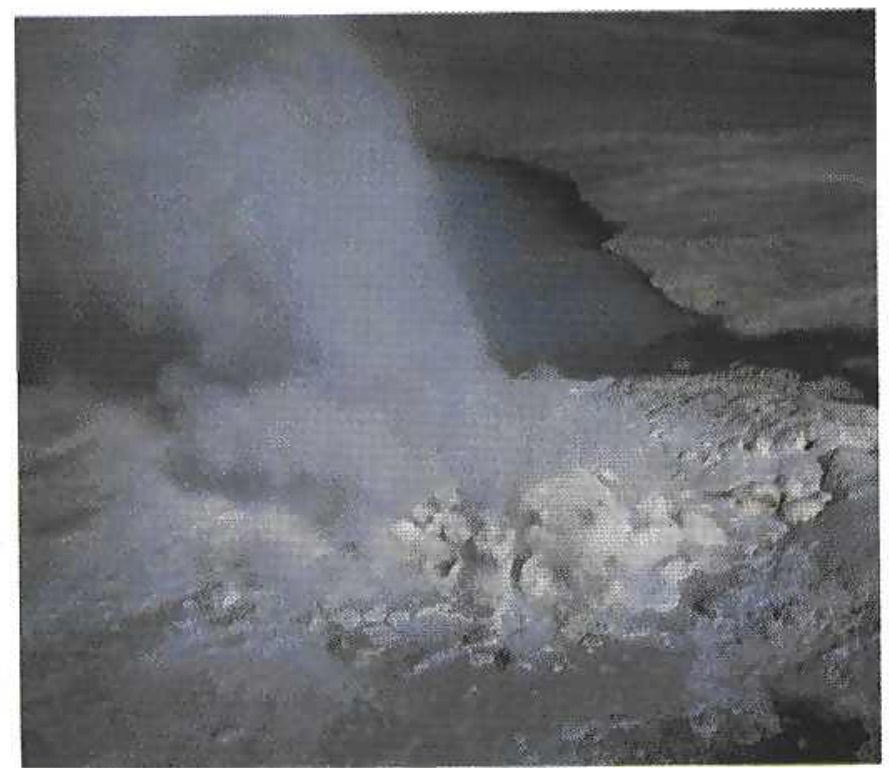

FIGURE 7.-Self-sealing multiple vents southeast of Opal Spring, Porcelain Terrace (pl. 1, D6-NW). Water in Opal is opalescent blue from light-scattering colloidal $\mathrm{SiO}_{2}$ polymerized in pool. Diameter of pool is about $4 \mathrm{~m}$. Photographed September 1947.

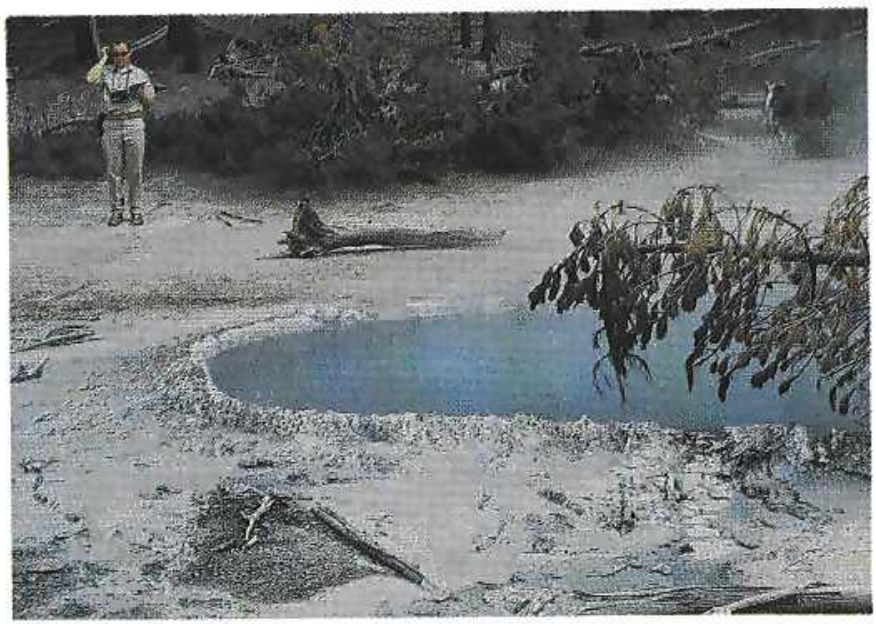

FIGURE 8.-Cistern Spring (pl. 1, F5-W) three hours after Steamboat Geyser had started its major eruption of June 3, 1968, and nearly two years after Cistern's response to Steamboat's eruption had become evident. Degree of superheat and water level have both started to decline. Tree on right (brown) killed by heat but small trees (above pool) not yet killed or flooded. 
geyser channels have been cut into this tuff, generally with so little associated sinter that joint planes and surfaces are still clearly exposed. Vents of Sunday, Basin, Ledge (fig. 14), and Valentine (fig. 15) Geysers, and Hurricane Vent are other examples where sinter is rarely thick enough to map. The vents and channels of Steam-

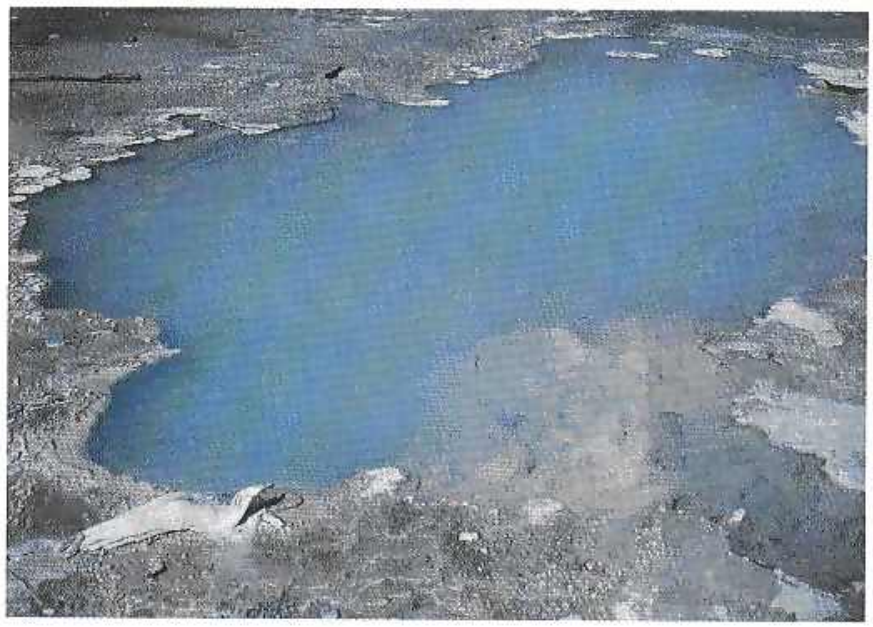

FIGURe 9.-Coral Spring (pl. 1, G4-NW) discharging high-SiO $\mathrm{S}_{2}$ water that ponds and cools enough to polymerize to light-scattering colloidal $\mathrm{SiO}_{2}$ with characteristic opalescent-blue color. Note thin sinter crusts deposited at water level and flowline trends (center). Piece of wood in left foreground is about $0.3 \mathrm{~m}$ long. Photographed September 1959. boat Geyser (pl. 1, F5) were eroded so extensively by the major eruptions of 1961-69 that thicknesses of previously existing sinter can be measured (fig. 16). Where preserved, sinter is seldom thicker than $10 \mathrm{~cm}$ except immediately around the geyser cone, where $\sim 0.5 \mathrm{~m}$ locally exists.

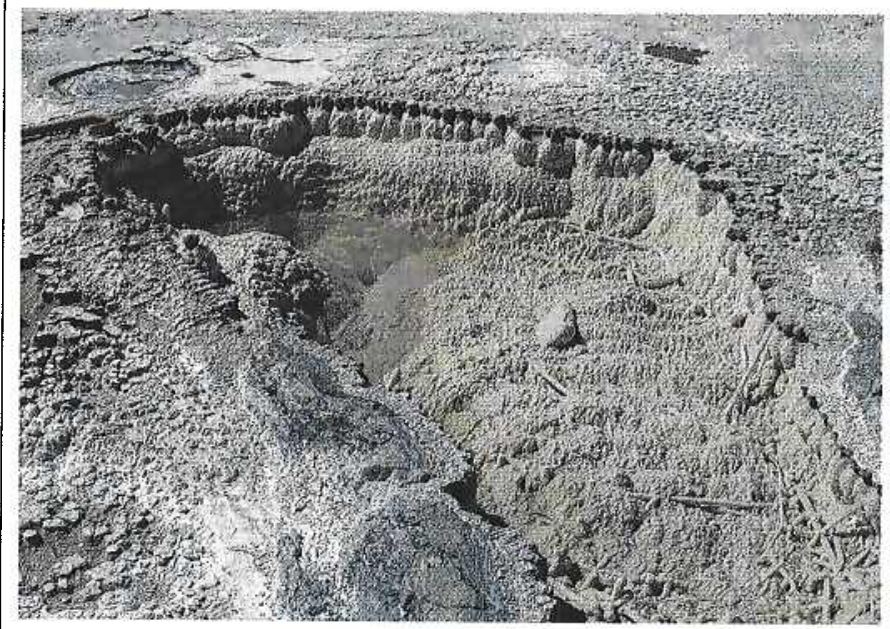

FIGURE 11.-Porkchop Geyser (spring; pl. 1, F4-SW) hours after its eruption of September 3, 1972. Pool normally clear or opalescent blue with slightly surging minor discharge, shown here as nearly empty but refilling. Note details and colors of opaline sinters above (white and gray) and below (tan) normal water level. Rock near center is about $4 \mathrm{~cm}$ in diameter.

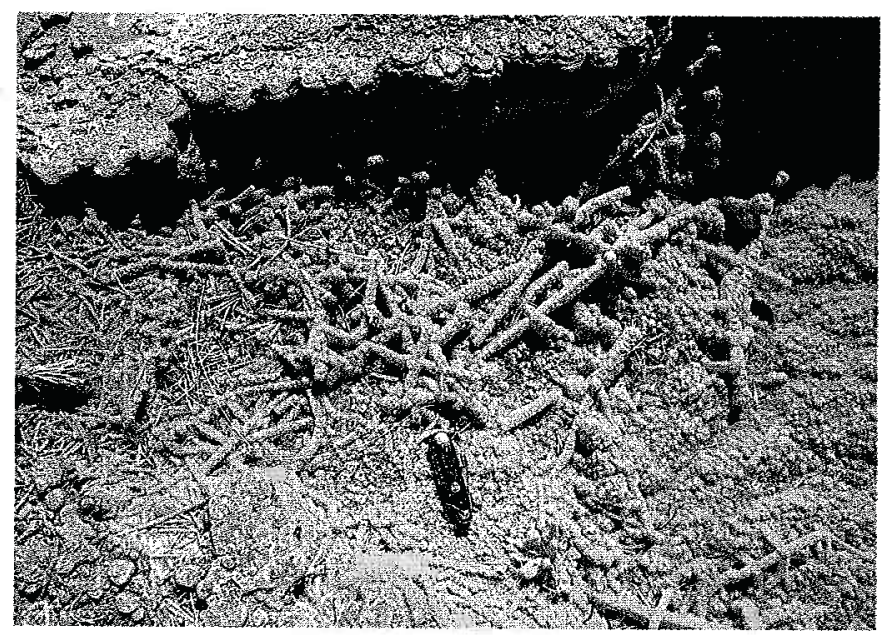

FIGURE 12,-Closeup of north end of Porkchop Geyser (spring), showing pine needles, small cones, and grass encased by opaline $\mathrm{SiO}_{2} . \mathrm{Cl}$ and $\mathrm{SiO}_{2}$ contents of this spring are consistently near the maximum of Norris Basin. See pocket knife for scale. Photographed September 3, 1972. 
Although concentrations of $\mathrm{SiO}_{2}$ in the various Norris waters account for some differences in rate of deposition of sinter, $\mathrm{pH}$ of the water is at least as important. Deposition is relatively fast from waters containing 400 to 700 ppm $\mathrm{SiO}_{2}$, provided that $\mathrm{pH}$ is 6 or higher. In contrast, deposition is exceedingly slow from waters with $\mathrm{pH}$ much below 6 , and the $\mathrm{pH}$ of many waters of Porcelain and Back Basins range from 3.5 to about 2 (table 4).

Thick Holocene sinter has been deposited locally in the past. A large area near Hydrophane Springs (pl. 1, G3, G4, F4-SW) is underlain by sinter that is probably more than $3 \mathrm{~m}$ thick (table 3), of which $2.1 \mathrm{~m}$ is Holocene in age. Present water levels have generally been 0.5 to 1.5 $\mathrm{m}$ below the surface of the surrounding sinter, so no discharge other than vapor normally occurs. Discharge during early Holocene time must have been much more vigorous than in recent times and probably was neutral to slightly alkaline in $\mathrm{pH}$. A recurrence of activity near Hydrophane Springs started in 1982 and continued through 1987 (fig. 17). Several vents discharged vigorously, rapidly depositing sinter from opalescent water that disappears down other nearby vents and is possibly discharged from a shallow subsurface permeable zone into Gray Lakes (suggested by extensive killing of stunted pine trees between these two features).

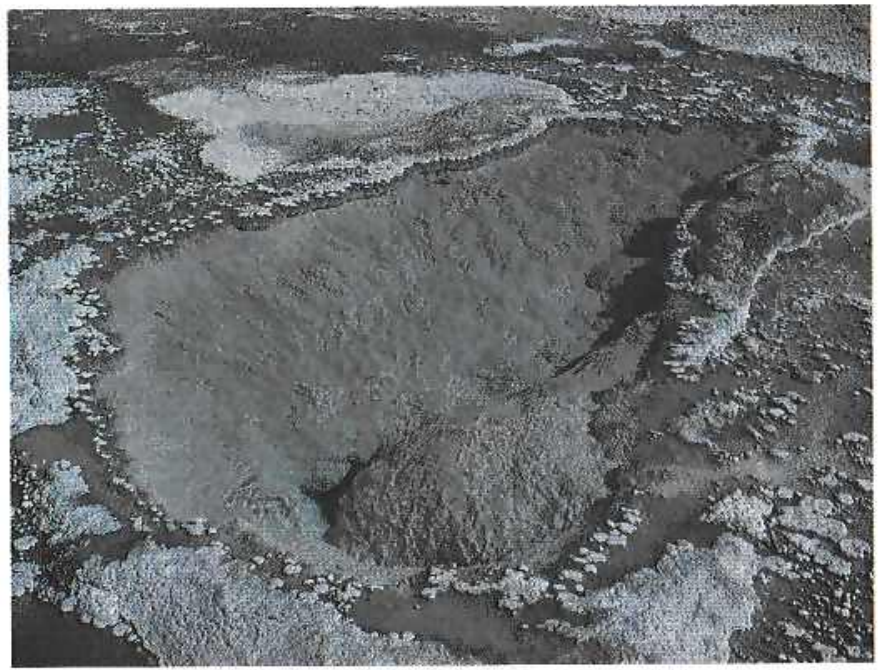

FIGURE 13.-Porkchop Geyser (spring), showing flowline trends in sinter. Hottest water rises from vent (foreground, slightly blue), flows out over pool's surface (low density) and cools, then descends down maximum slope (compare with swirling descent at Coral Spring, fig. 9). Residence time of water in this pool is seldom long enough for $\mathrm{SiO}_{2}$ to polymerize, but the opalescent blue of colloidal $\mathrm{SiO}_{2}$ has been observed. Brown algae grows on cool borders that are continuously wet; white sinter is dry except during eruptions when temperatures are too high and variable to sustain algae. Photographed September 2, 1959 .

\section{ALLUVIAL AND LAGUSTRINE DEPOSITS}

Much low-lying ground in the northwestern and western parts of Norris Basin is mapped as a single map unit, designated as al. Much time and effort was spent in attempting to map meaningful subdivisions, but these efforts were abandoned.

The composite unit contains fine-grained stream sediments, lacustrine deposits, local hot-spring sinter, and slope wash. Some patches of sinter are distinguished, but many small patches are not. Drainage is poor throughout One Hundred Spring Plain (pl. 1, B4, C3, C4, and adjacent areas to the south); levels and dimensions of ponds and lakes change rapidly with seasonal precipitation and runoff. At times of rapid snowmelt, much of this area is a single shallow lake. Many low-discharging springs

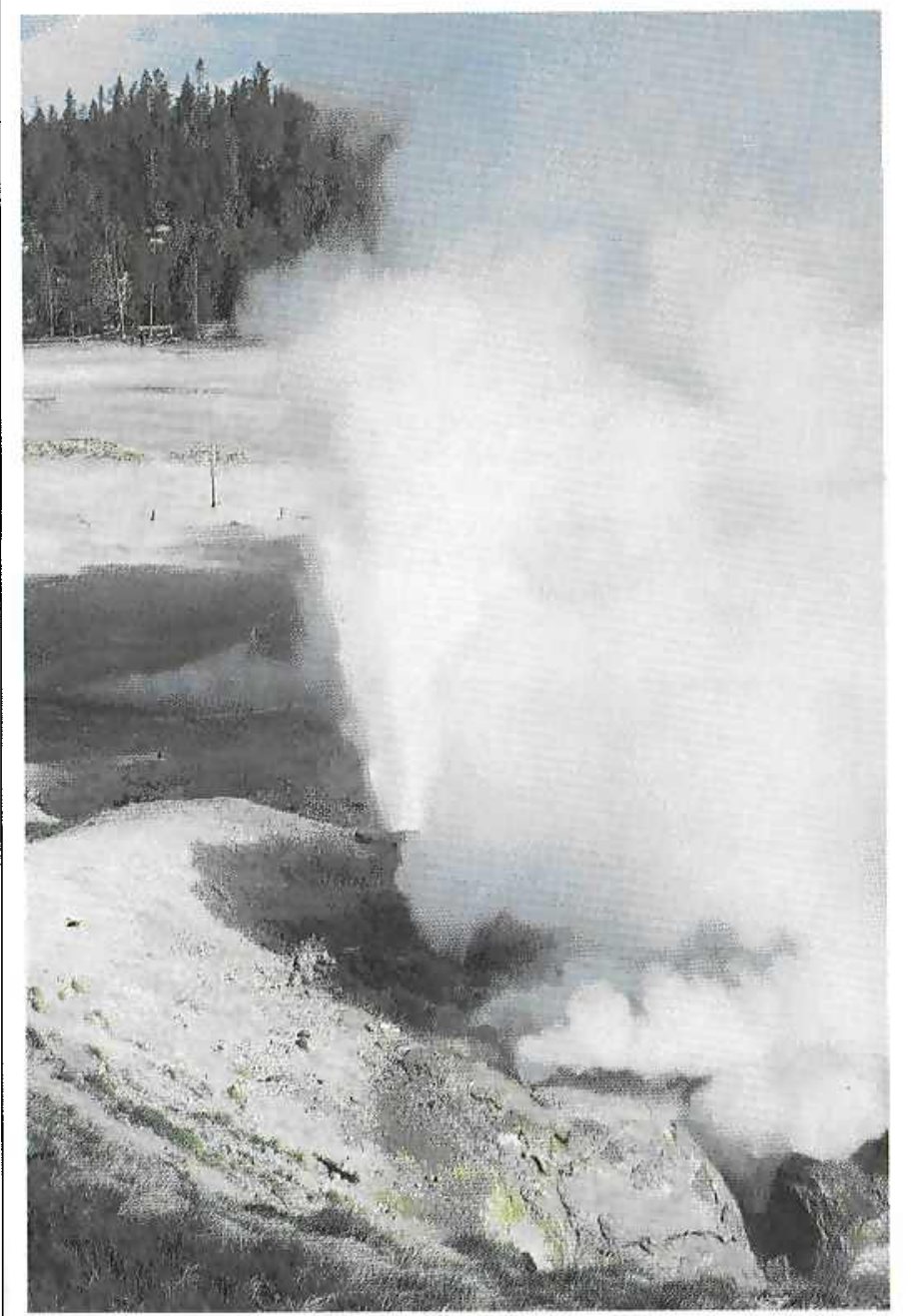

FIGURE 14.--Ledge Geyser's multiple vents (pl. 1, D5-SW), looking northwest, showing a northwest-striking fracture in Lava Creek Tuff controlling vent locations. Sinter is white, and green vegetation in left foreground indicates minor spray from geyser. Photographed May $27,1968$. 
supply silica that, with evaporation, provides opaline cement to the fine-grained clastic stream and lacustrine sediments. Some material that was first interpreted as rounded sand grains actually consists of small concretionary oolites of opal chemically precipitated on clastic nuclii. X-ray diffractograms of this concretionary sand

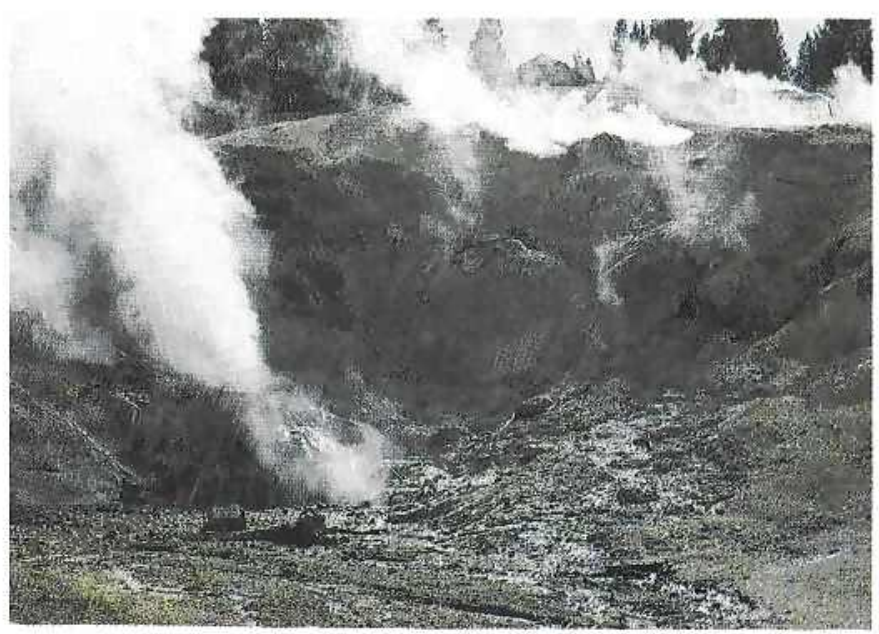

FIGURE 15.-Valentine Geyser (pl. 1, D5-SW; strongest steam plume on left) and dispersed vents of Black Growler (fumaroles, center and upper right) distributed around margins of Valentine's crater cut into block-jointed Lava Creek Tuff. Note bleached (gray) borders and unbleached (red-brown) centers of joint blocks behind Valentine's steam plume, right side. Photographed September 29, 1967.

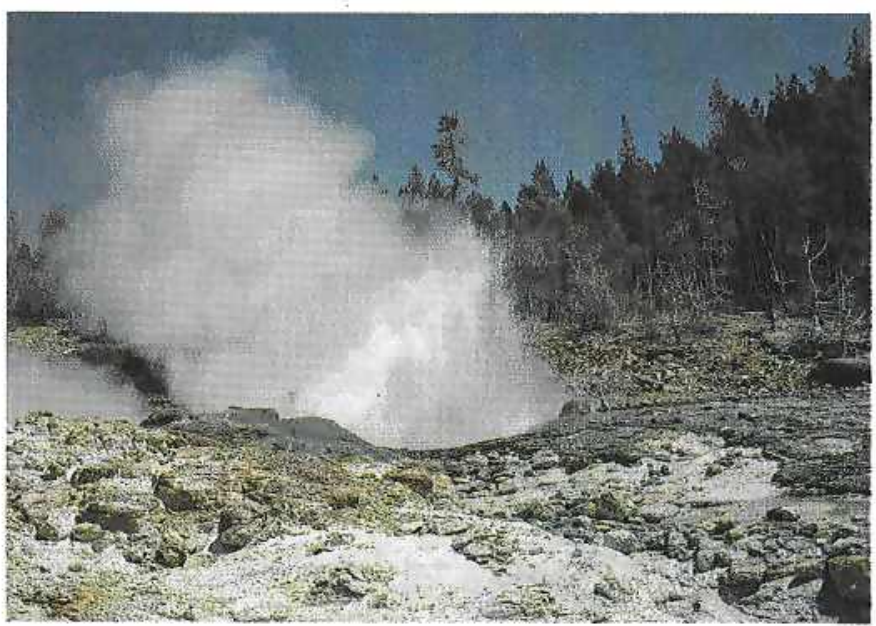

Figure 16.-Steamboat Geyser (pl. 1, F5-NW) in minor normal eruption. The rounded white and brown blocks are residual from hydrothermally altered Lava Creek Tuff, stripped of most gray sinter by ejecta from the major eruptions of the 1960's. Also, note dead and dying (brown) pine trees as much as $60 \mathrm{~m}$ from vents. Temperature data for water of this minor eruption ( $\sim 5 \mathrm{~m}$ high) from southeastern vent are shown in figure 49. Photographed July 8, 1965. reveal dominant amorphous opal, minor alunite and quartz, rather abundant $\alpha$-cristobalite, and abundant tridymite. The last three silica minerals are clastic products of devitrified and fragmented Lava Creek Tuff. The channels of Tantalus Creek north of Ragged Hills are immediately underlain by hard opal-cemented clastic material produced by evaporation of stream water high in silica and low in $\mathrm{pH}$ and temperature.

Because conditions change rapidly with stage of runoff, the different deposits consist of thin, nearly horizontal beds, and their contacts change rapidly from time to time in a random manner, thus preventing meaningful projections to the horizontal plane of a geologic map.

Sediments mapped as al in the southern and northeastern parts of the basin consist of uncemented sandy debris that slopes gently toward the branches of Tantalus Creek. Other steep-gradient tributaries adjacent to cemented older Pinedale kame deposits, as in the areas shown on blocks D3 and E3 of plate 1, are also included in the unit. These areas were mapped by Richmond and Waldrop (1975) as Pinedale alluvial deposits that "form gently sloping alluvial fans where streams open into basins or valleys." These areas are all downslope from cemented older Pinedale kame deposits. The local drainages probably were more active during late stages of Pinedale glaciation, but present chemical activity and intervals of rapid post-Pinedale runoff still supply abundant clastic sediments for alluvial fans. Thus, with a good "wastebasket" unit (al) already available for Holocene sediments, a separate map unit was considered unnecessary.

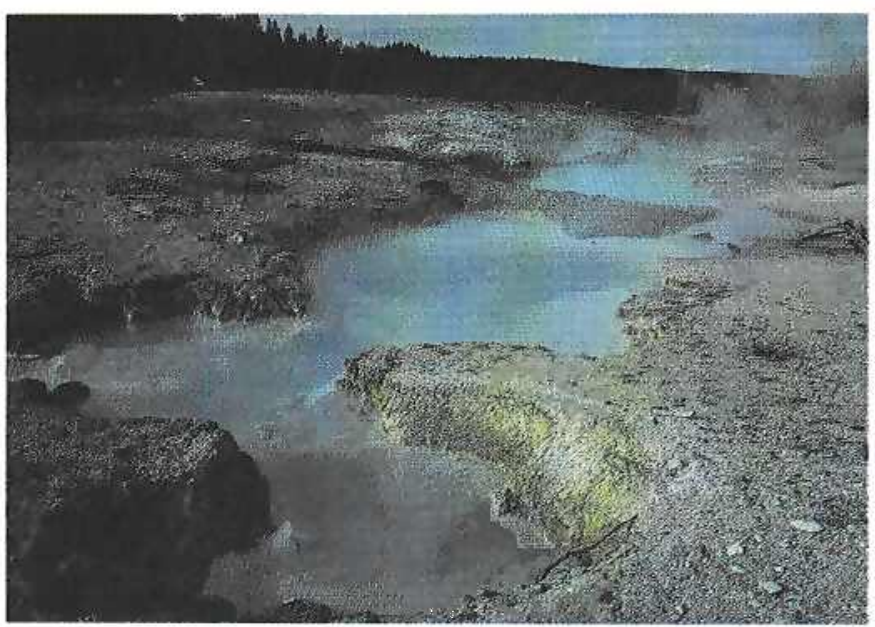

FIGURE 17.-Hydrophane Springs (pl.1, G3-SE) after widespread reactivation in 1982. For many years this area of thick white sinter (gray and brown on weathered surfaces) had no surface discharge but had standing water levels and local boiling $\sim 2 \mathrm{~m}$ below general level. Here, opalescent high- $\mathrm{SiO}_{2}$ water has discharged and polymerized from new high-level vents and flowed subsurface perhaps into lower vents, eastward into Gray Lakes. Photographed April 1983, looking north; nearest pool is 1 to $1 \frac{1}{2} \mathrm{~m}$ in diameter. 


\section{STRUGTURE}

\section{FAULTS}

Norris Geyser Basin is about $4 \mathrm{~km}$ north of the northwest rim of the Yellowstone caldera (fig. 1). This part of the caldera rim was not identified on the Gibbon-Norris segment of the U.S. Geological Survey 1972 park map, but its possible position as a prominent scallop under younger lava flows is suggested on Christiansen's (1975) map of the Norris Junction quadrangle. Faults on this map extend outward from the general caldera rim for distances of 3 to $8 \mathrm{~km}$. At greater distances north and northwest of the scallops, these radial trends near Norris Basin merge into north-trending faults that define the NorrisMammoth Corridor (figs. 1 and 18) and northeast-trending faults related to the Hebgen Lake system.

No fault with obvious measurable displacement has been recognized within Norris Basin. A fault trending northwest from Nuphar Lake was shown on the U.S. Geological Survey (1972) map of the park but was relocated on Christiansen's (1975) Norris Junction map to the east side of the Norris block because the contact between members $A$ and $B$ of the Lava Creek Tuff along the vertical section shown in figure 2 showed no significant vertical displacement. The absence of other mappable divisions of the Lava Creek Tuff prevents recognition of small faults that may exist elsewhere in the basin.

\section{FRACTURES}

Well-developed systems of fractures characterize the best exposed outcrops of Lava Creek Tuff, including deep roadcuts on the southeast margin of Norris Basin and tuff exposures in geyser and spring vents (pl. 1, D5; previously noted for scarcity of sinter). Notable examples are Hurricane Vent and Valentine (fig. 15), Ledge (fig. 14), and Basin Geysers, where borders and deep channels of these vents are defined by fracture systems. Numerous spring vents are aligned, and some individual vents suggest that they were formed by enlargement of fractures (Marler and White, 1975). However, a large part of the basin area is underlain by disintegrating Lava Creek Tuff, glacial debris, and sediments that yielded no direct data on fractures in the underlying bedrock. Some stream drainages, ponds, and borders of basins show such well-defined linear trends that they are almost certainly controlled by fractures or faults (fig. 5). Also, several major shifts in heat supply have occurred in recent years, killing vegetation along linear trends. These trends are most commoniy northerly, ranging from N. $15^{\circ}$ E. to N. $20^{\circ}$ W.

In addition to these features, bedrock fracture patterns are revealed in Norris Basin in an unusual way. Photographs show the distribution of bare ground, normal forest, and intermediate ground characterized by stunted pine trees (as in fig. 5). The differences in vegetation are controlled by soil chemistry, near-surface ground temperatures, and drainage. Many linear trends evident on plate 1 and figure 19 are due to fractures controlling the rise of thermal fluids through underlying welded tuffs. When soils are too high in temperature or too acid from oxidation of $\mathrm{H}_{2} \mathrm{~S}$, lodgepole pines either do not grow or normal growth is impeded (stunted pines).

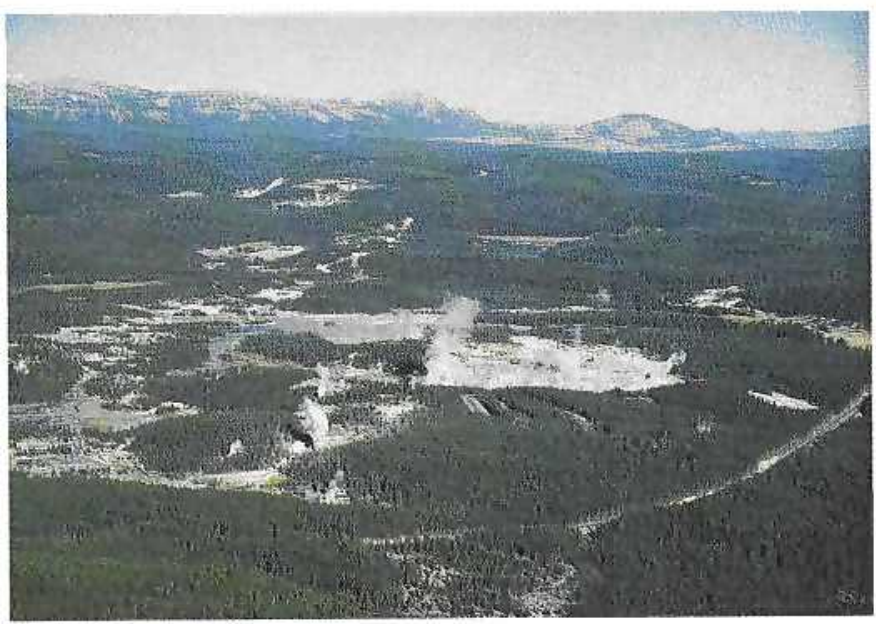

FIGURE 18.-Aerial photograph looking north-northwest over Norris Basin, the Norris-Mammoth Corridor, and Roaring Mountain, the prominent white alteration scar in the distant left. Sinter and acidbleached ash-flow tuffs are white, and water-logged meadows are tan. Sparse vegetation of two channels in central foreground is caused by warm dilute acid meteoric springs (type IIb, table 4). Photographed October 18, 1967

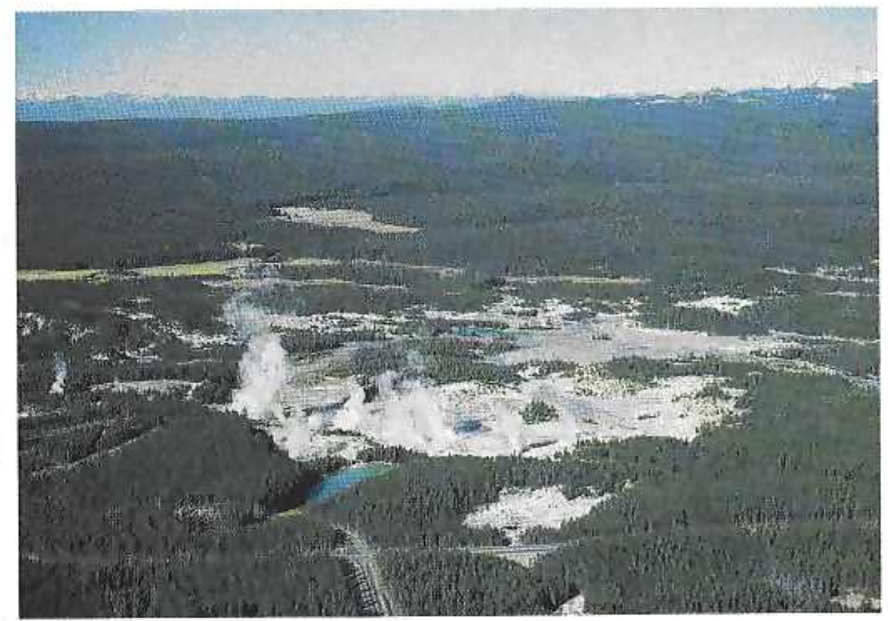

FIGÚRe 19.-Aerial photograph looking west-northwest over Nuphar Lake (lower left, blue; pl. 1, D6-SW), Porcelain Basin (white and bluish), and the Annex Area (lower center beyond road; pl. 1, D6-E). Photographed October 18, 1967. 
On the assumption that hydrothermal alteration and tree growth patterns reflect directions and magnitudes of fracture systems in the underlying Lava Creek Tuff, a separate version of plate 1 (not published) was constructed and evaluated to determine if an overall pattern of fractures could be established statistically. Drainage lines, observed fractures, and treeline trends were counted within each block of plate 1 and plotted as rose diagrams. Personal judgment of the observer was used to determine whether an individual trend was linear enough to be counted or was irregular enough to be ignored. Short linear trends that spanned the boundary between two blocks were included in the block containing more than 50 percent of the feature. Long features that crossed block boundaries were counted in each block.

We had hoped that some systematic pattern would clarify the underlying cause of the especially intense activity in Norris Basin. For example, if the lobe of pumiceous obsidian (Norris Dome) centered $2 \mathrm{~km}$ southeast of Norris Museum was actually extruded from an underlying magma chamber, a pattern of fractures might radiate from this center. Individual blocks of the coordinate system of plate 1 generally contain too few trends to be statistically meaningful, so the blocks were divided into northern, central, and southern tiers, each two blocks wide, and each tier was divided into an eastern and western half. The western half of the central tier, for example, included six blocks, D1 through D3 and E1 through E3. Rose diagrams were constructed for structural trends in each of the six groups (and in other block combinations), and another diagram was constructed for the whole basin. These diagrams demonstrate that fracture trends differ within the basin, but no easily interpreted pattern emerged.

A second observer was then asked to repeat the experiment, using the same groups of blocks and also using his subjective judgment on which altered areas and topographic trends were sufficiently linear to be counted. The two observers differed considerably in their interpretations of each individual group, but trends for the whole basin were similar, showing a well-defined northeast trend and a broad north-to-northwest trend. The second analysis of data for the whole basin is shown in figure $20 \mathrm{~A}$. The second observer was skeptical that his pattern of 216 observations was any more significant than his plot of 200 values from tables of random numbers (shown as fig. $20 B$ ). However, one major difference does exist: each maximum or submaximum of figure $20 \mathrm{~A}$ has adjacent distributions only slightly less abundant, just as natural systems of fractures normally have. In contrast, in figure $20 B$, each maximum is bordered by abundance differences 2 or 3 groups lower on the scale. Also, note that Christiansen's maps of the Norris Junction (1975) and Madison Junction (1974) quadrangles show noticeable northeast trends in geologic and topographic features that reflect fault or fracture control, crudely concentric to the general caldera border and parallel to the most significant trend of figure $20 \mathrm{~A}$.

Detailed analyses of mapped structural trends thus have not helped significantly in understanding why Norris Basin is specifically localized where it is. The northeast trends were derived largely from drainage patterns and ponds in the northwestern part of the basin, and the broad north-to-northwest trends occur in part in the same area but are also more widely dispersed through other parts of the basin. We had hoped that some recognizable pattern might emerge, such as one related to vertical uplift from magma pressure under or perhaps southeast of the center of the basin.

Smith and Christiansen (1980) recognized a belt of active seismicity that trends east-southeast from the observed Hebgen Lake faults of 1959 to the caldera boundary near Norris Basin (fig. 1). The geologic map of the park (U.S. Geological Survey, 1972) shows only two faults that might be involved in surface displacements related to this seismic zone, but neither fault was traced more than $18 \mathrm{~km}$ east of the park's west boundary, terminating a few kilometers west of Norris Basin. Outcrops of the pre-Tertiary rocks of the Gallatin Range terminate at the south end of the range, plunging downward roughly along the Hebgen-Norris seismic zone. If this fault zone is significant and old, but obscured near the surface by ash-flow tuffs for many kilometers west of Norris, the thermal activity of the basin is then explained as being localized near the intersection of three major structuresthe northwest rim of Yellowstone caldera, the NorrisMammoth Corridor, and the Norris-Hebgen seismic zone.

\section{SUMMARY OF CHEMICAL WATER TYPES AND THEIR PROPOSED ORIGINS}

To this point, chemical names have been applied to the major water types of Norris Basin without specifically describing their chemical compositions. Two to four key words are used for their major chemical and physical characteristics. Complete gradations exist among most types, so typical examples of major varieties most significant to the basin are listed in table 4 .

\section{NEARLY NEUTRAL WATERS HIGH IN GL AND $\mathrm{SIO}_{2}$}

The most fundamental of Yellowstone's thermal waters, generally being the highest in $\mathrm{Cl}$ and $\mathrm{SiO}_{2}$ of all types and providing the strongest evidence for very high subsurface temperatures (from drill holes and chemical geothermometers; Fournier and Truesdell, 1970; White, 1970; Fournier and others, 1976; Truesdell, 1976), is designated as type I. This type is generally nearly neutral in $\mathrm{pH}$, ranging from about 6 to 8 , and the waters in deep pools are 
either clear blue or opalescent blue (from light-scattering by colloidal $\mathrm{SiO}_{2}$ ). By weight of dissolved constituents, $\mathrm{Cl}$ is dominant at Norris but may be nearly equaled by $\mathrm{SiO}_{2}$ (all silica species calculated as $\mathrm{SiO}_{2}$ ). $\mathrm{SO}_{4}$ varies greatly and is commonly the second most abundant anion. Combined $\mathrm{CO}_{2}$ species are notably low, in contrast to most other geothermal systems of Yellowstone and elsewhere.

Such waters, prior to heating and attaining their chemical characteristics, are recharged from distant sources, as indicated by their light stable isotopes and absence of ${ }^{3} \mathrm{H}$ (tritium, the radioactive hydrogen isotope, not discussed in detail in this paper).

\section{DILUTE RECHARGING METEORIC WATERS}

Type II waters consist of cold to warm dilute meteoric waters from rain and snow. Type IIa is nearly neutral in $\mathrm{pH}$ (table 4) and is assumed to be the major source of local mixing and dilution of the chloride waters of the basin. Although largely confined to subsurface flow, type IIa waters do occur as seeps and springs of moderate temperature on the basin margins.
Type IIb (table 4) is a special variant of dilute meteoric water that emerges on the lower slopes of Norris Dome (pl. 1, H3, H4, G5, G6). These springs are modest in temperature (27 to $54^{\circ} \mathrm{C}$ measured) and are unusual in being acid ( $\mathrm{pH}$ of 2.1 to 4 ) and of low to considerable discharge (1-30 L/min; at least $50 \mathrm{~L} / \mathrm{min}$ for group). Some have green to black algal mats and thin spinose sinter (fig. 21). The origin of their acidity is not positively known, but the favored explanation involves oxidation of $\mathrm{H}_{2} \mathrm{~S}$ and native sulfur known to occur in low-temperature gases in undrained depressions near the crest of Norris Dome about $2 \mathrm{~km}$ south-southeast of the Norris Museum. Christiansen's (1975) map of the Norris Junction quadrangle shows this dome (previously unnamed), which has many acid-altered areas and undrained subsidence depressions. Precipitation falls on the dome and is assumed to dissolve the oxidized acid products of sulfur and $\mathrm{H}_{2} \mathrm{~S}$, which then sink underground through the porous depression bottoms and is then available for mixing with the deep Cl-rich water of type I. This mixing may explain some of the puzzling acid Cl-SO $\mathrm{S}_{4}$ waters of the southeast margin of the basin.

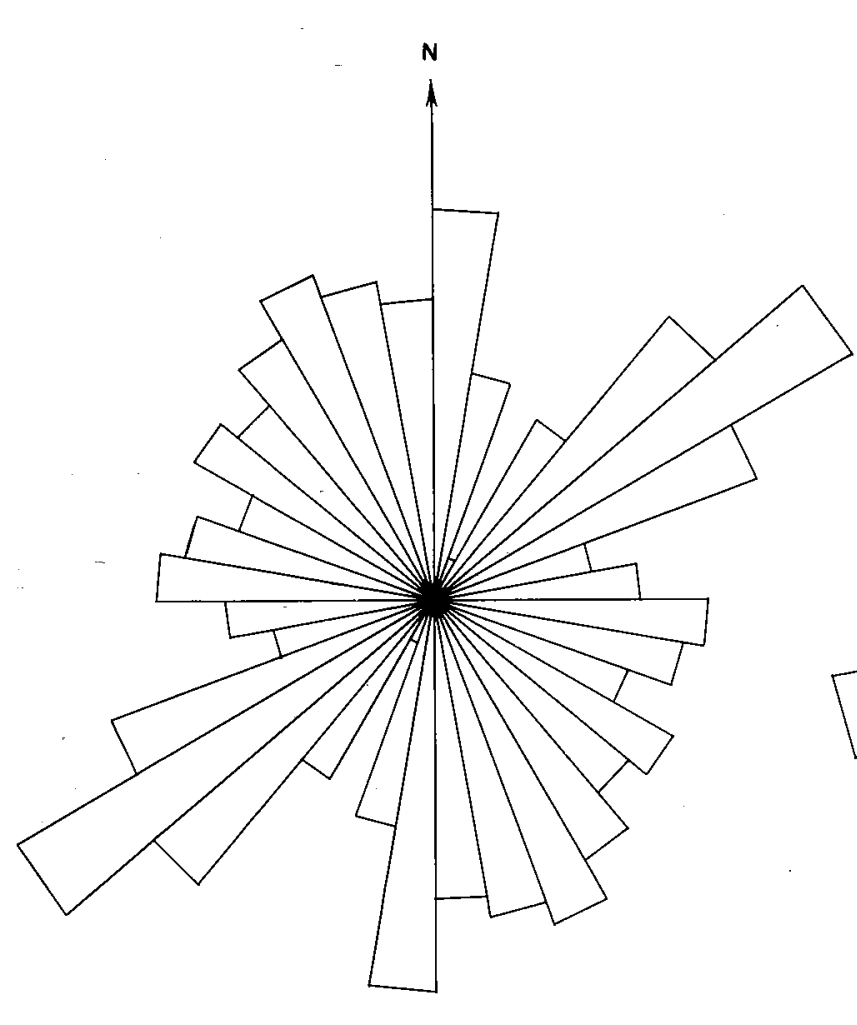

A

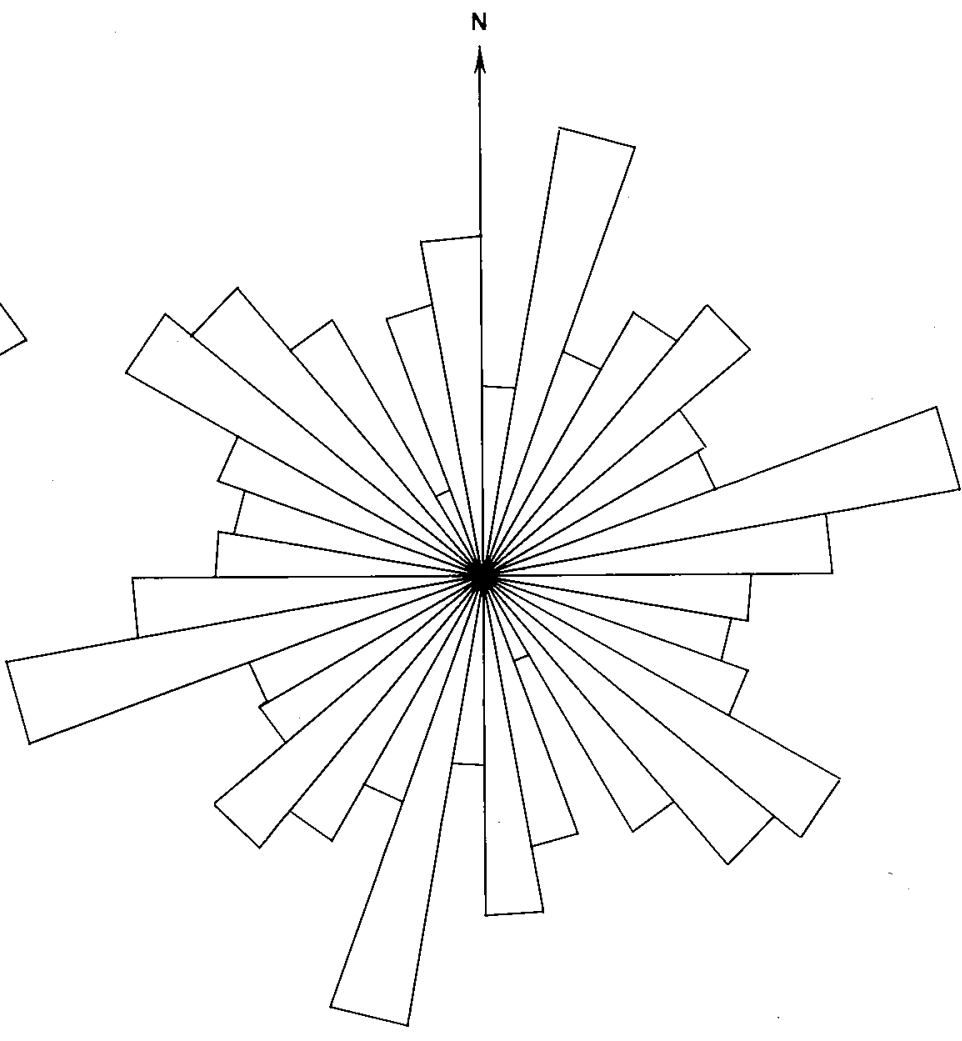

$B$

FIgURE 20.-Rose diagrams of linear trends in Norris Basin. $A$, Fracture trends, using 216 data points from plate $1 . B$, Random trends, using 200 data points from tables of random numbers. 


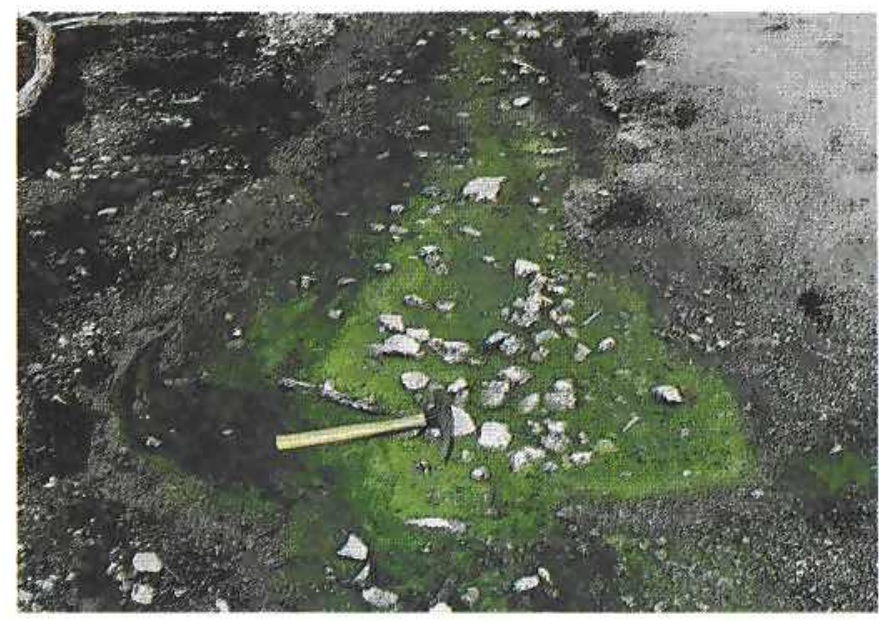

FIGURE 21.-A warm dilute acid spring (pl.1, G6 center; $\mathrm{pH} \sim 2.4$, table 4), believed to represent acid meteoric recharge from near the crest of Norris Dome. Green colors are from acid-loving microorganisms, probably coolest on left; sinter fragments in central yellow-green band are generally dry on top sides, with spinose sinter from alternate wetting and drying. Photographed May 21, 1966.

This favored explanation for dilute acid meteoric recharge may sound improbable but is supported by some evidence. The undrained subsidence depressions near the crest of Norris Dome show no evidence for filling or overflow even during heavy precipitation or extensive snowmelt. In addition, Echinus Geyser, described in the following section, has been observed to undergo a puzzling temperature reversal during an eruption, a behavior not known to have been recorded elsewhere. Other acid springs of modest temperature, similar to type IIb (table 4), also occur elsewhere on the lower flanks of Norris Dome.

Tritium, the radioactive isotope of hydrogen, is a very useful means of identifying young diluting meteoric water in a mixture of old deeply circulating water, as shown by Pearson and Truesdell (1978), but has not been utilized here.

\section{ACID CL-SO 4 (OR SO $\left.\mathrm{SO}_{4}-\mathrm{CL}\right)$ WATERS}

Acid waters rich in $\mathrm{Cl}$ and $\mathrm{SO}_{4}$ constitute type III; we have not been rigorous in distinguishing $\mathrm{Cl}_{-} \mathrm{SO}_{4}$ waters from $\mathrm{SO}_{4}$-Cl waters, but, where analyzed, the most abundant anion (in parts per million) is listed first. These waters may form in several ways. Water from Echinus Geyser (type IIIa, table 4; figs. 22, 23) is probably a nearsurface mixture of deep Cl-rich water (type I) and shallow warm acid meteoric water (type IIb). Local generation of $\mathrm{H}_{2} \mathrm{SO}_{4}$ in the required quantities is unlikely near Echinus, which also demands extensive dilution of the $\mathrm{Cl}$ content normal for type I of Norris Basin. Green Dragon Spring (type IIIb, table 4; fig. 24) may also contain some deep $\mathrm{Cl}$ water diluted with shallow acid recharge, as proposed for Echinus. However, on several occasions D.E. White has estimated that Green Dragon's rate of discharge into Gray Lakes was similar in magnitude (estimated $\sim 120$ $\mathrm{L} / \mathrm{min}$ ) to the total being discharged out of Gray Lakes, which includes other springs from the south (such as the Alcove group, pl. 1, H4, and other nearby warm and hot springs). The apparent anomaly is solved if $\mathrm{H}_{2} \mathrm{~S}$ is oxidized in Gray Lakes through high-temperature bacterial oxidation (Brock and others, 1972; Brock and Mosser, 1975) and if Green Dragon consists in considerable part of recirculated Gray Lakes water.

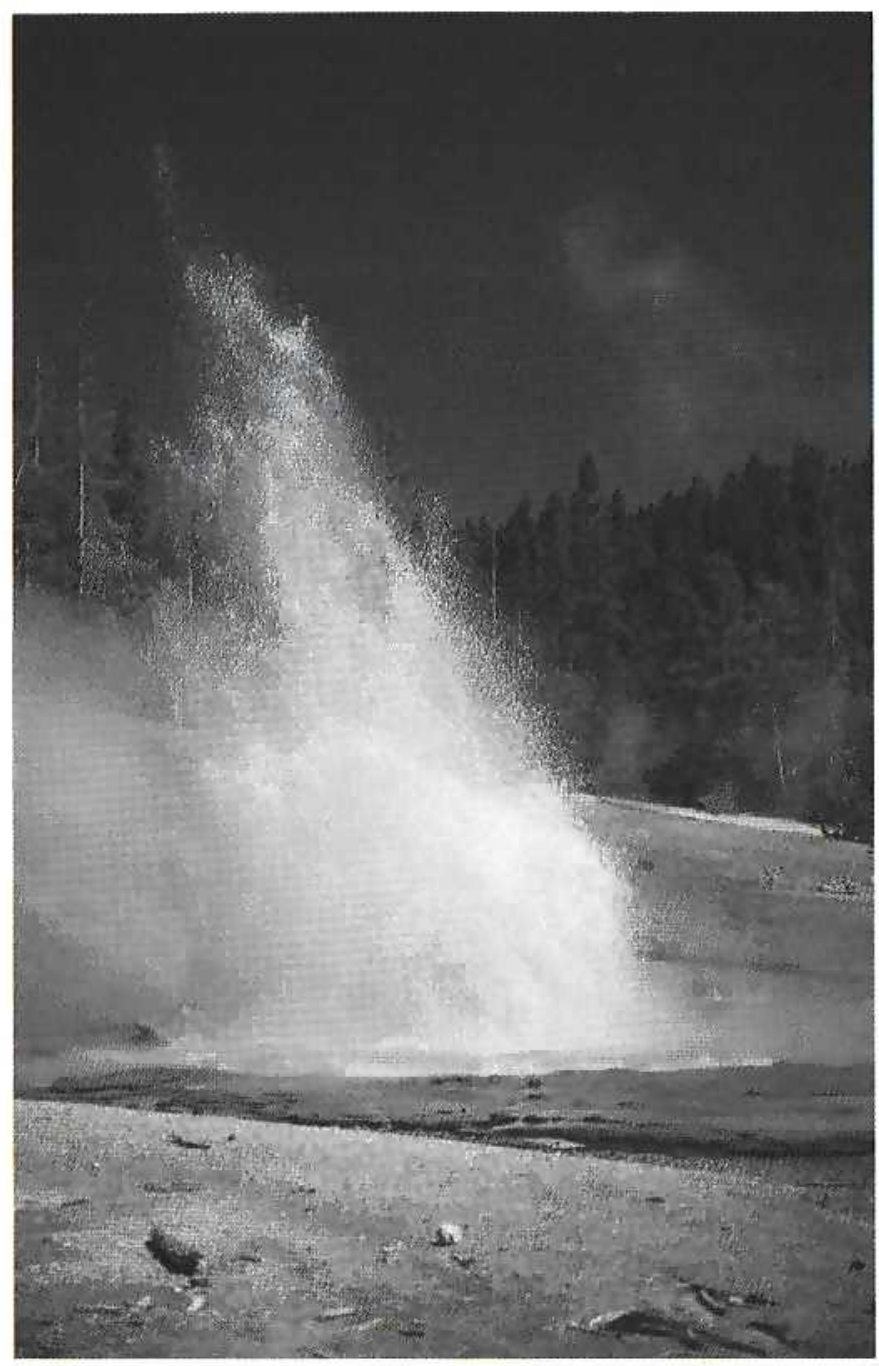

FIGURE 22.-Echinus Geyser (pl. 1, F5-SE) erupting acid $\mathrm{SO}_{4}-\mathrm{Cl}$ water, common in Norris Basin but rare in most geyser areas of the world. Photograph by Jennifer Whipple, August 1979. 


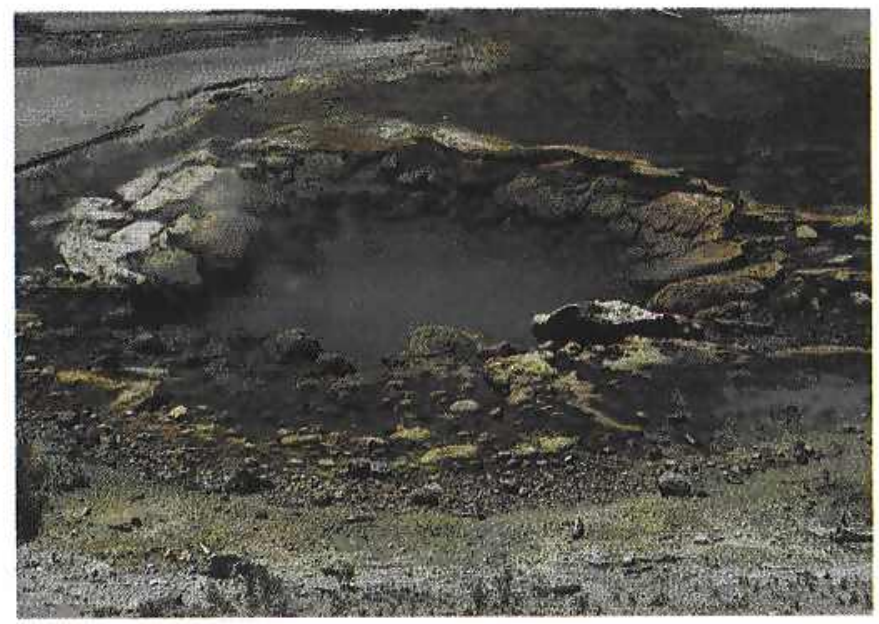

FIGURE 23.-Echinus Geyser pool and discharge area about 5 minutes after the end of an eruption in July 1965. Brown and yellow-brown spinose sinter is characteristic of sinter from acid water high in $\mathrm{Fe}$, $\mathrm{Mn}, \mathrm{As}$, and $\mathrm{Al}$, which here covers old blocks of opaline sinter, white on fresh surfaces, underlain $\sim 1 \mathrm{~m}$ by logs yielding a ${ }^{14} \mathrm{C}$ age of $\sim 530$ years B.P. Diameter of pool at the then-existing water level was $\sim 2$ $\mathrm{m}$. Interlayered pyrite and marcasite occur in veins as much as $1 \mathrm{~cm}$ wide near and below water level.

Recirculation of surface-acidified water is a reasonable and attractive hypothesis for many acid springs and geysers that are high in $\mathrm{Cl}$ (but lower in $\mathrm{Cl}$ than the example of type I, table 4) and also have discharge altitudes near the flat-floored Porcelain Basin ( 7,480 ft; figs. 25, 26), the Back Basin ( 7,500 ft; fig. 27), and the flats of western Norris ( $\sim 7,475 \mathrm{ft}$; fig. 28 ). Recirculation to even slightly higher discharge altitudes is also possible where subsurface heat can be supplied to cause boiling, expansion, and "steam lift."

\section{ACID-SULFATE WATERS}

Type IV waters are characteristically low in $\mathrm{Cl}$ and discharge and generally situated on locally high ground. They may be chemically similar to the acid recharge of type IIb but originate from subsurface boiling of Cl-rich waters of types I and III (fig. 29). Steam and $\mathrm{H}_{2} \mathrm{~S}$ separate from the underlying chloride water; the steam in part condenses, and $\mathrm{H}_{2} \mathrm{~S}$ is oxidized either inorganically or through involvement of S-oxidizing bacteria. Type IV waters are commonly nearly boiling, their discharge rates are typically low or nil, and they are frequently associated with other water types (or evolve into such types, as demonstrated by the two analyses of Opal Spring on Porcelain Terrace, table 4). Similar fluctuations in type have been observed near Carnegie II drill hole and elsewhere.

\section{RECENT HYDROTHERMAL ACTIVITY OF NORRIS GEYSER BASIN}

Of all hydrothermal areas in Yellowstone Park, Norris Basin has the greatest variety of physical and chemical features. Many individual features are described briefly in table 5, and all vents known to have erupted as geysers (69 named features) are listed in table 6 . Some but not all of the more notable features are also described in the following pages, not in full recorded detail but sufficiently to obtain an overview of the kinds of activity and

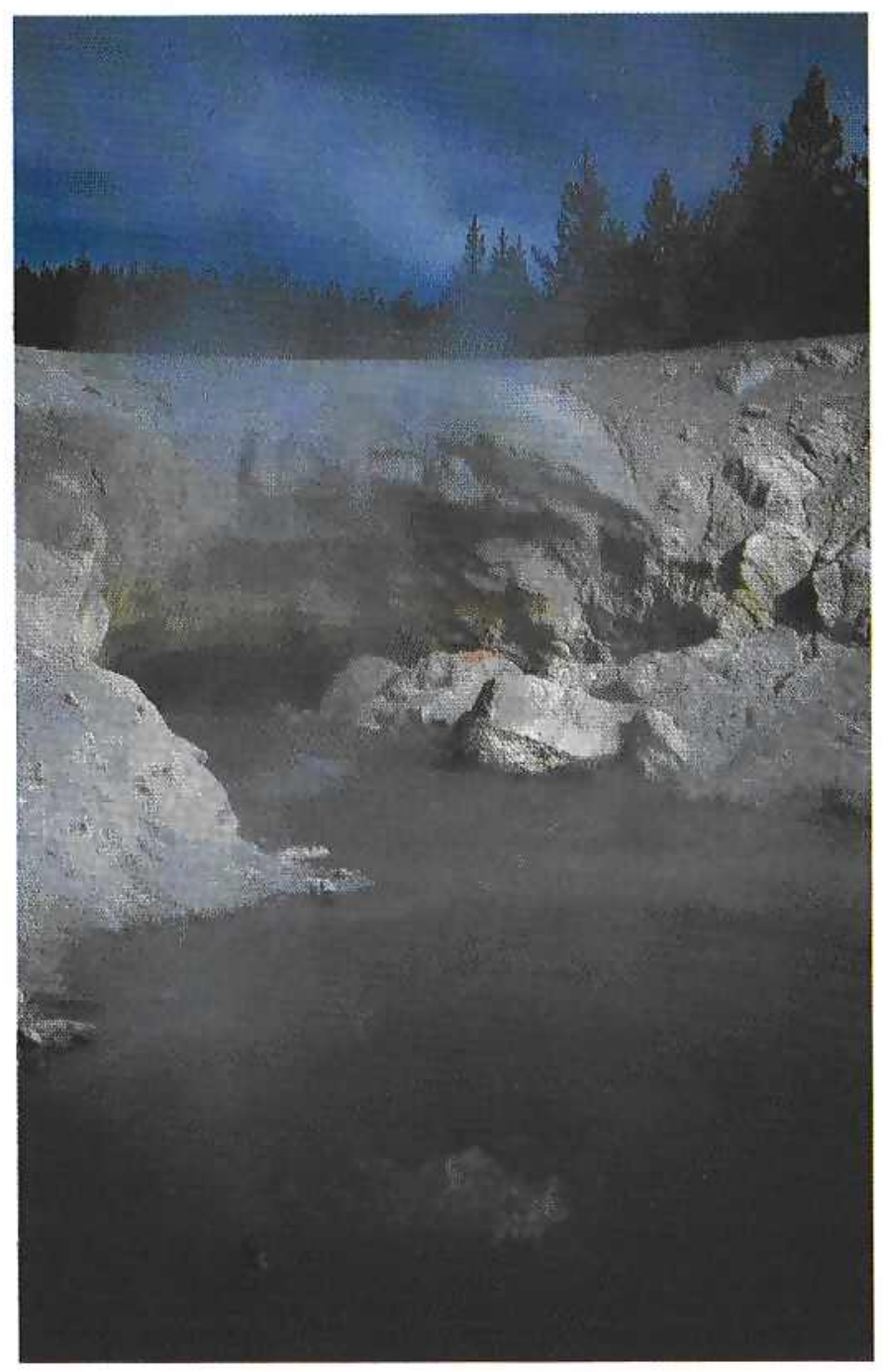

FiguRE 24.-Green Dragon Spring (pl. 1, G4-SW), discharging acid $\mathrm{Cl}-\mathrm{SO}_{4}$ water of long-debated origin (see text). Only visible production of $\mathrm{S}$ and sulfates (yellow and orange) is on roof and sides of Dragon's Mouth. Water discharges from three vents (one under ledge) into Gray Lakes, and both features have nearly the same total discharge. Green Dragon is now viewed as partly recirculated Gray Lakes' water in which thermophylic organisms oxidize $\mathrm{H}_{2} \mathrm{~S}$ to sulfate at high temperatures. Surging in foreground is about $0.4 \mathrm{~m}$ in diameter. Photographed September 1947. 
changes that occur. Outstanding examples are: (1) Black Growler, superheated fumarole (fig. 30); (2) Opal Spring on Porcelain Terrace, acid and neutral to alkaline springs high in $\mathrm{Cl}$ and $\mathrm{SiO}_{2}$, commonly changing at irregular intervals to acid $\mathrm{Cl}-\mathrm{SO}_{4}$ springs and acid-sulphate springs low in Cl (fig. 31); (3) Congress Pool, normally a nondischarging acid $\mathrm{Cl}-\mathrm{SO}_{4}$ pool (fig. 32), at times with mud

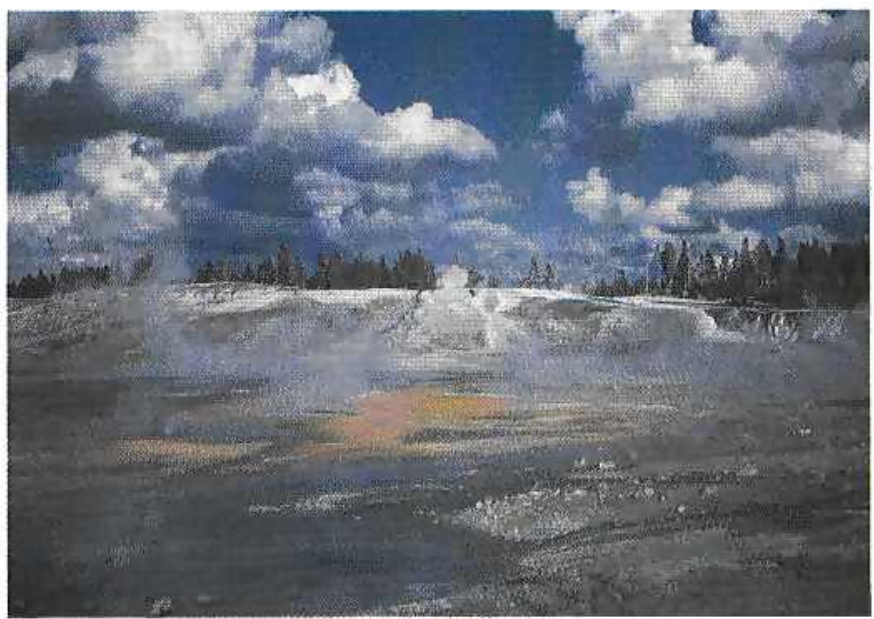

Figure 25.-Central Porcelain Basin (pl. 1, D5), with many acid and few neutral springs, looking northeast to Porcelain Terrace, an area of frequent changes, where youngest sinter is white and old sinter is gray to tan. Photographed September 1947.

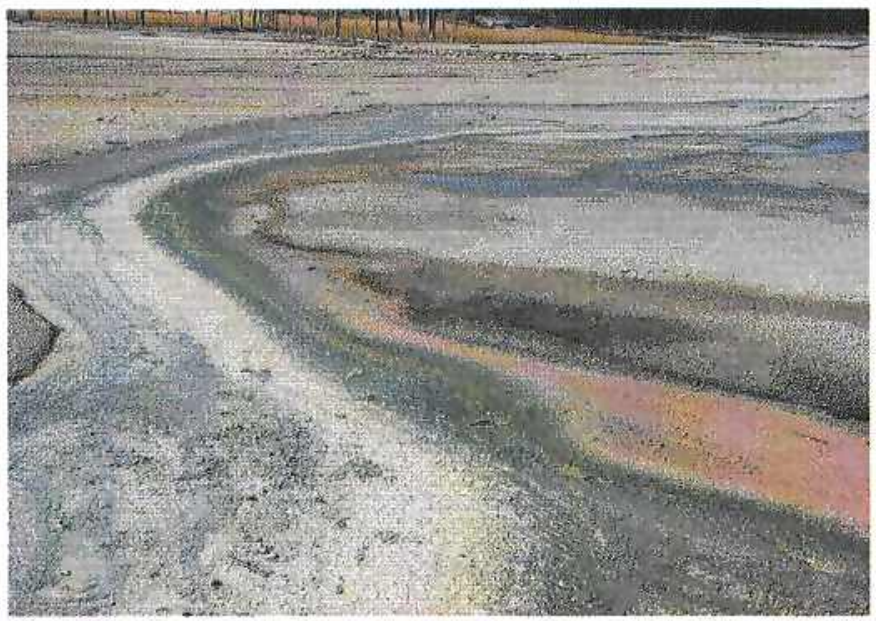

Figure 26.-Merging of nearly neutral and acid discharge streams in Porcelain Basin (pl. 1, D5-W center). Colors are mostly from inorganic chemical precipitates, but greens are thermophilic organisms. Photographed September 1, 1969. pots. Congress Pool has also been an active geyser and a quietly discharging neutral chloride spring (fig. 33); (4) Locomotive Springs, acid- $\mathrm{SO}_{4}$ water; (5) Cinder Pool, a spring with a deep subsurface cauldron of molten sulfur as well as floating black sulfur "cinders" on the surface (fig. 34). Cinder Pool is the only example of its type yet identified in the United States (see subsection "Cinder

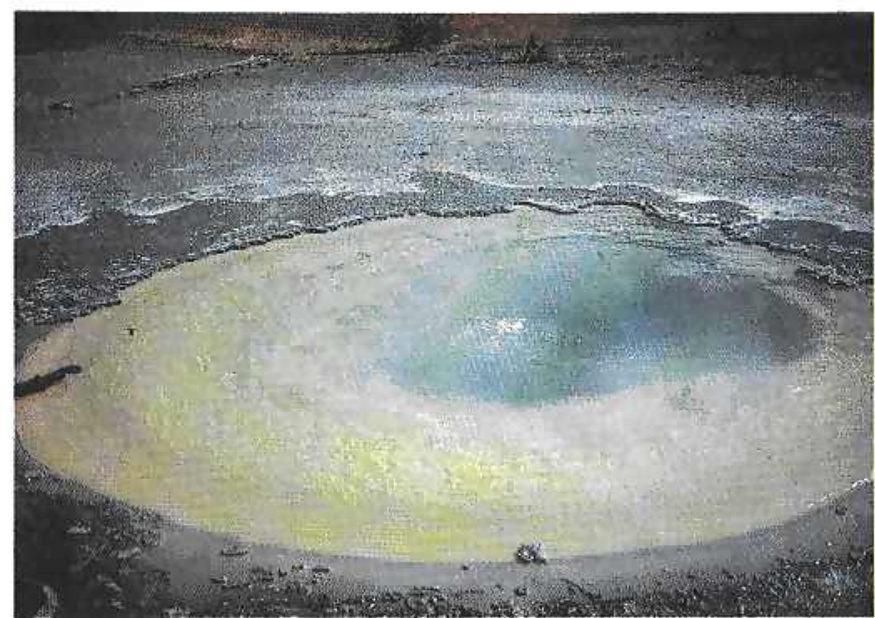

FIGURE 27.-Yellow Funnel Spring (pl. 1, G4-NW), showing color variations from blue green (deepest part of vent), yellow (sulfur), orange brown (Fe sulfates), and purple (ferric sulfate, not studied in detail). In recent years this spring has been generally turbid and unattractive; diameter about 3 m. Photographed September 1947.

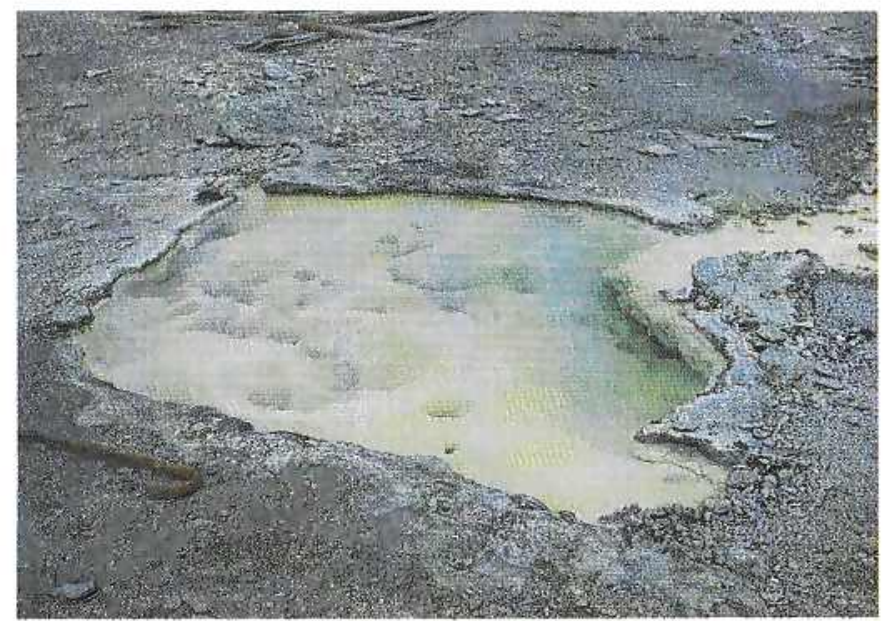

FIgURE 28.-Sulfur Dust Spring (pl. 1, A4-S center), depositing flocculated sulfur (yellow) but little or no sinter. Acid $\mathrm{SO}_{4}-\mathrm{Cl}$ water and intermittent gas bubbles rise through the holes in the pool's bottom. Photographed July 10, 1968; note cane for scale. 
Pool"); (6) Steamboat Geyser, the highest erupting geyser yet recorded in the United States (frontispiece); (7) Steam Valve Geyser, mud pot or mud volcano, observed through one of its life cycles (second?) that included mud pot and geyser activity in 1946 . The same vent was reactivated as a small active geyser in 1982 (fig. 35A, B) and was still active in 1984 when its vent demonstrated a long com-

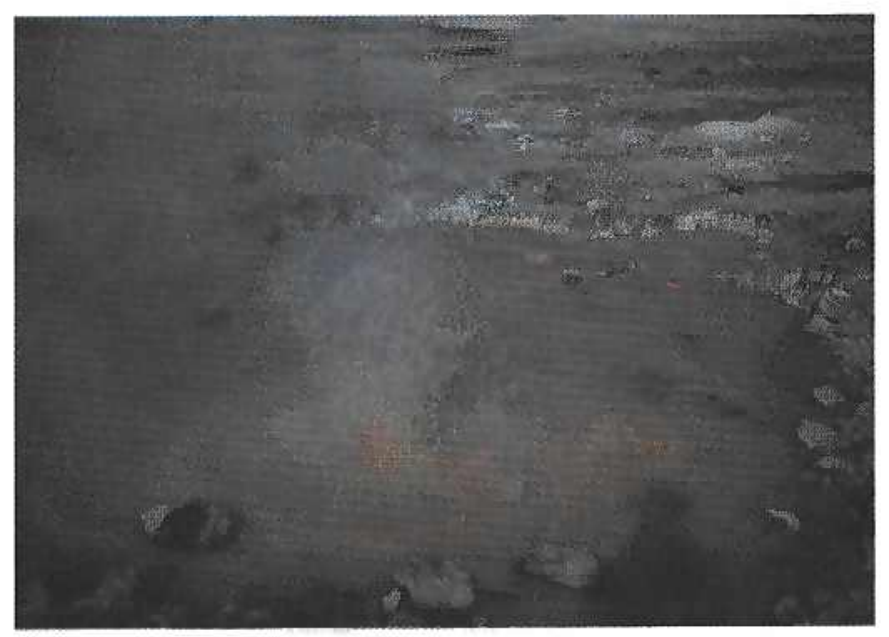

FIGURE 29.-Vermillion Spring (pl. 1, D5-SE), an acid $\mathrm{SO}_{4}$ water consisting of condensed steam, surface drainage, oxidized sulfate from $\mathrm{H}_{2} \mathrm{~S}$, and suspended ferric oxide; diameter about $2 \mathrm{~m}$. Color changes season to season and year to year as constituent proportions and $\mathrm{pH}$ change. Photographed September 1947.

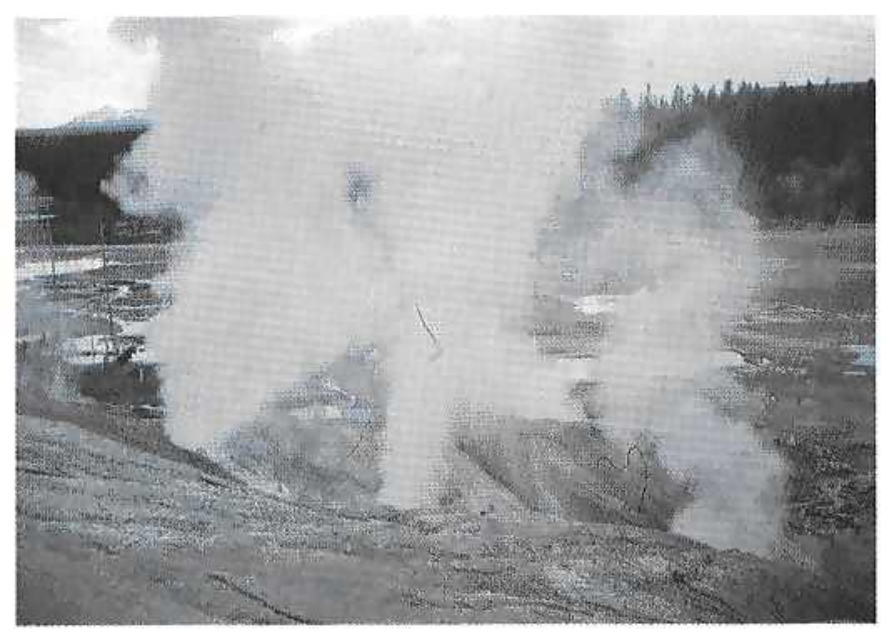

FIGURE 30.-Black Growler fumarole (pl. 1, D5-SW), which has had as many as five vents ranging in temperature from nearly boiling to $138^{\circ} \mathrm{C}$. The noisiest fumarole shifts from one to another with time; the hottest or noisiest is commonly called Black Growler (left vent in this photo). Photographed June 6, 1950. plex history, including human activity; (8) Carnegie II drill hole, the second geothermal hole in the world drilled for research purposes, 1929-30, in very hazardous ground (see subsection "Carnegie II Drill Hole"; fig. 36); (9) Porcelain Springs, including several minor hydrothermal explosions similar in nature to much larger prehistorical examples (Muffler and others, 1971; see subsection

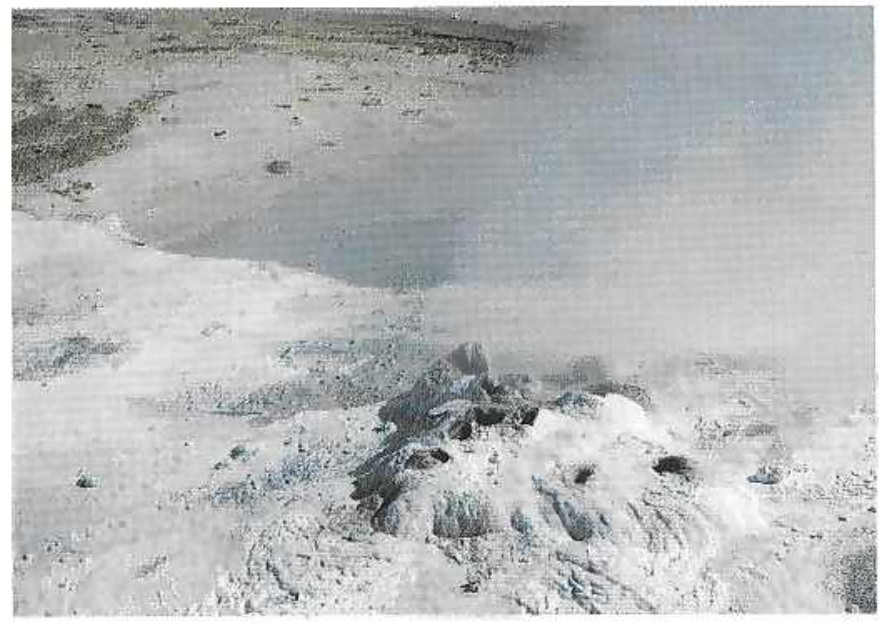

FIGURE 31.-Opal Spring (pl. 1, D6-NW), which had been discharging neutral opalescent high-SiO ${ }_{2}$ water prior to the Hebgen Lake earthquake of August 17, 1959 (similar to fig. 7), then changed to a nondischarging acidic pool. Photographed September 2, 1959.

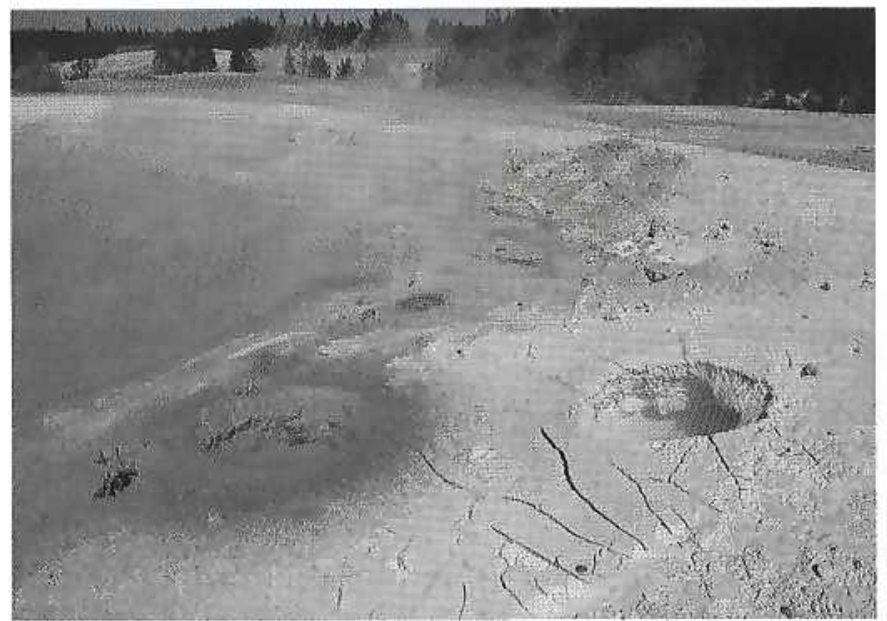

FIgURE 32.-Congress Pool (left; pl. 1, D5-SE), normally a large turbid acid $\mathrm{Cl}-\mathrm{SO}_{4}$ pool, had two new mud pots, each $\sim 0.3 \mathrm{~m}$ in diameter, on the crater's south rim on September 3, 1972, that resulted from the August 8, 1972, disturbance (table 8). Damp recently ejected mud (left foreground) is dark; older mud is light gray and has dessication cracks. Yellowish colors on far rim of pool are from $\mathrm{Fe}$ and Al sulfates. 


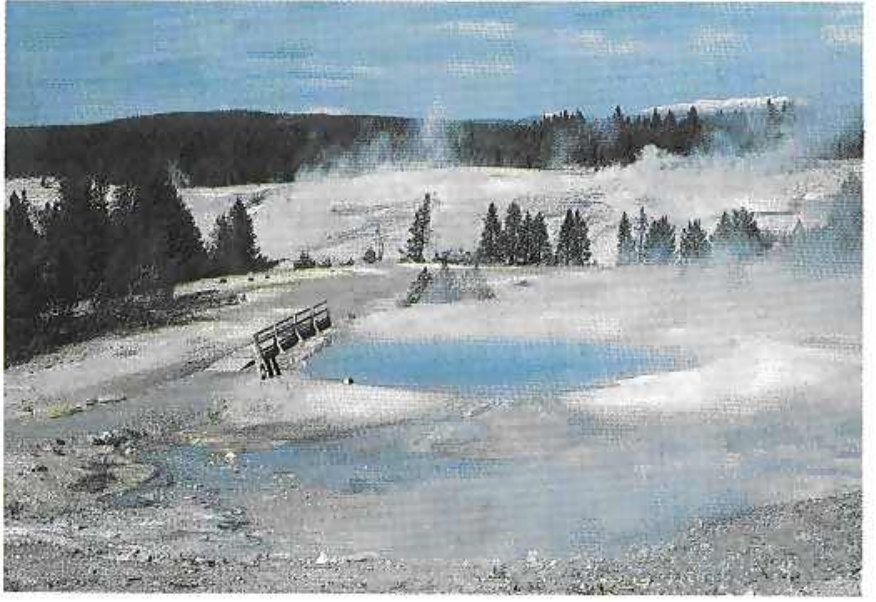

FIgure 33.-Congress Pool (spring) on September 30, 1972, photographed four weeks after figure 32 . Spring is shown discharging during a rare period of increased water level; pool diameter is $\sim 13 \mathrm{~m}$. Opalescent-blue neutral water increased in $\mathrm{Cl}$ and $\mathrm{SiO}_{2}$.

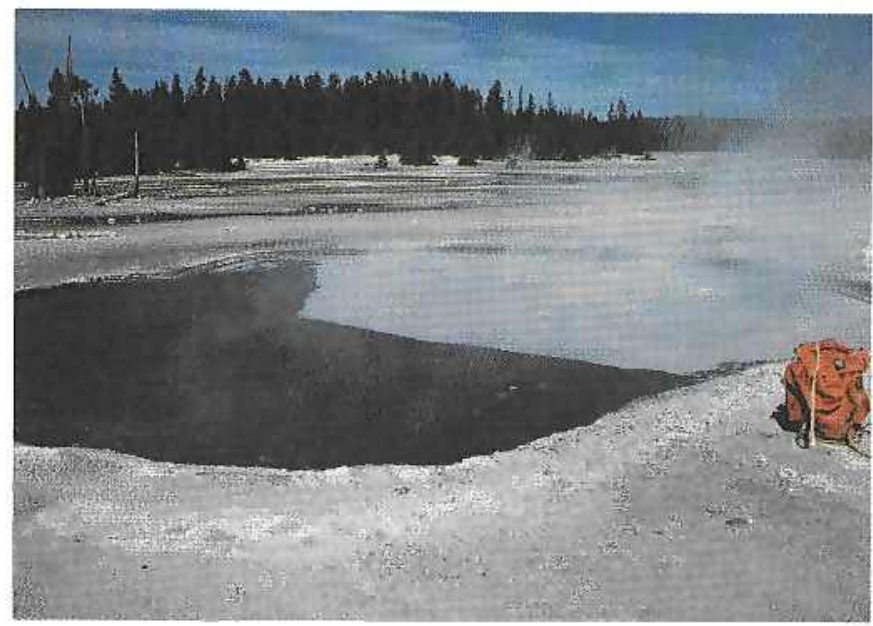

Figure 34.--Cinder Pool (pl. 1, C3-NE) on September 24, 1975, half covered with floating black "cinders" of native sulfur containing gas cavities and dispersed black iron sulfide. View is northward across Tantalus Creek.

Figure 35.-Steam Valve Spring (geyser and mud pot; pl. 1, E5 center), the highest altitude discharging vent of Norris Basin between 1946 and 1985. A, Discharging tan turbid water. Photographed by Jennifer Whipple, June 1982. B, Between eruptions. Reconstruction of its history suggests at least three different periods of activity. Pinedale till (just above water level) is overlain by cemented till and remnants of a cone of earliest opaline sinter. The cone was capped by blacktop of a former parking lot. A second period of activity (the first to have been observed) broke through the blacktop in 1947 (see text) and was again infilled about 1967, then finally reactivated in 1982-85. Photographed September 20, 1984.
"Porcelain Terrace and Porcelain Springs"; fig. 6); and (10) Realgar Springs, arsenic-depositing springs, unusual in the United States.

Of Yellowstone's total variety of thermal features, Norris Basin lacks only the travertine-depositing springs similar to those of Mammoth Terraces and Firehole Lake.

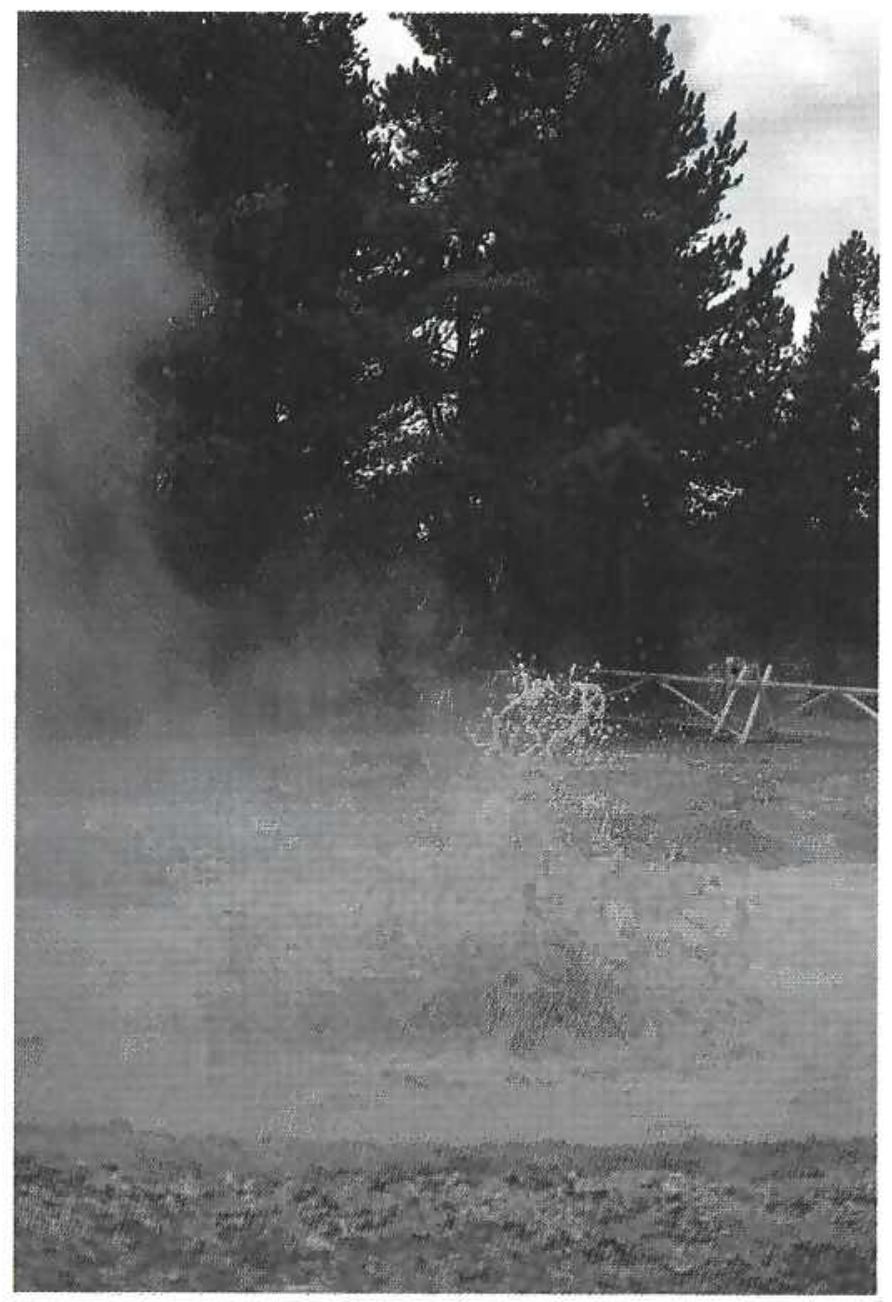

A

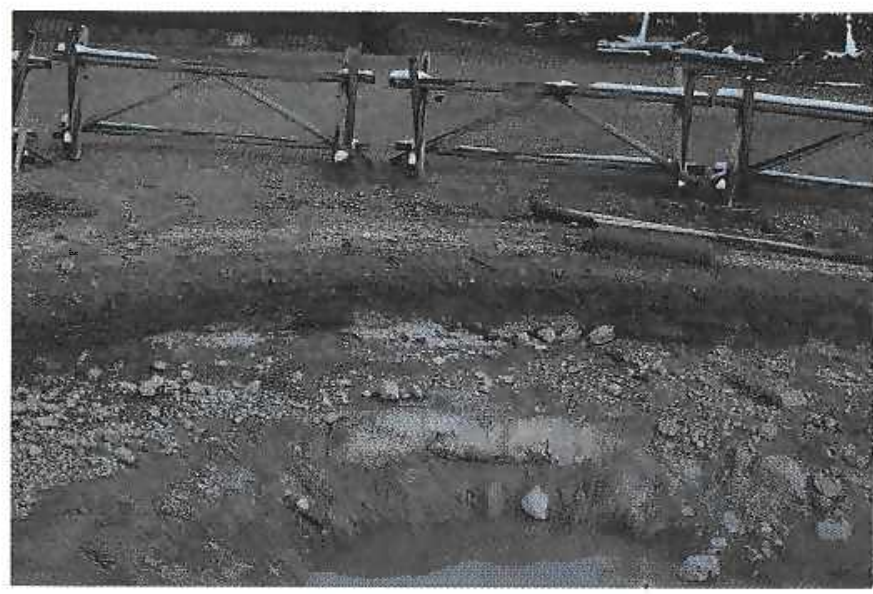

$B$ 
TABLE 5.-Summary of notable thermal features, Norris Geyser Basin

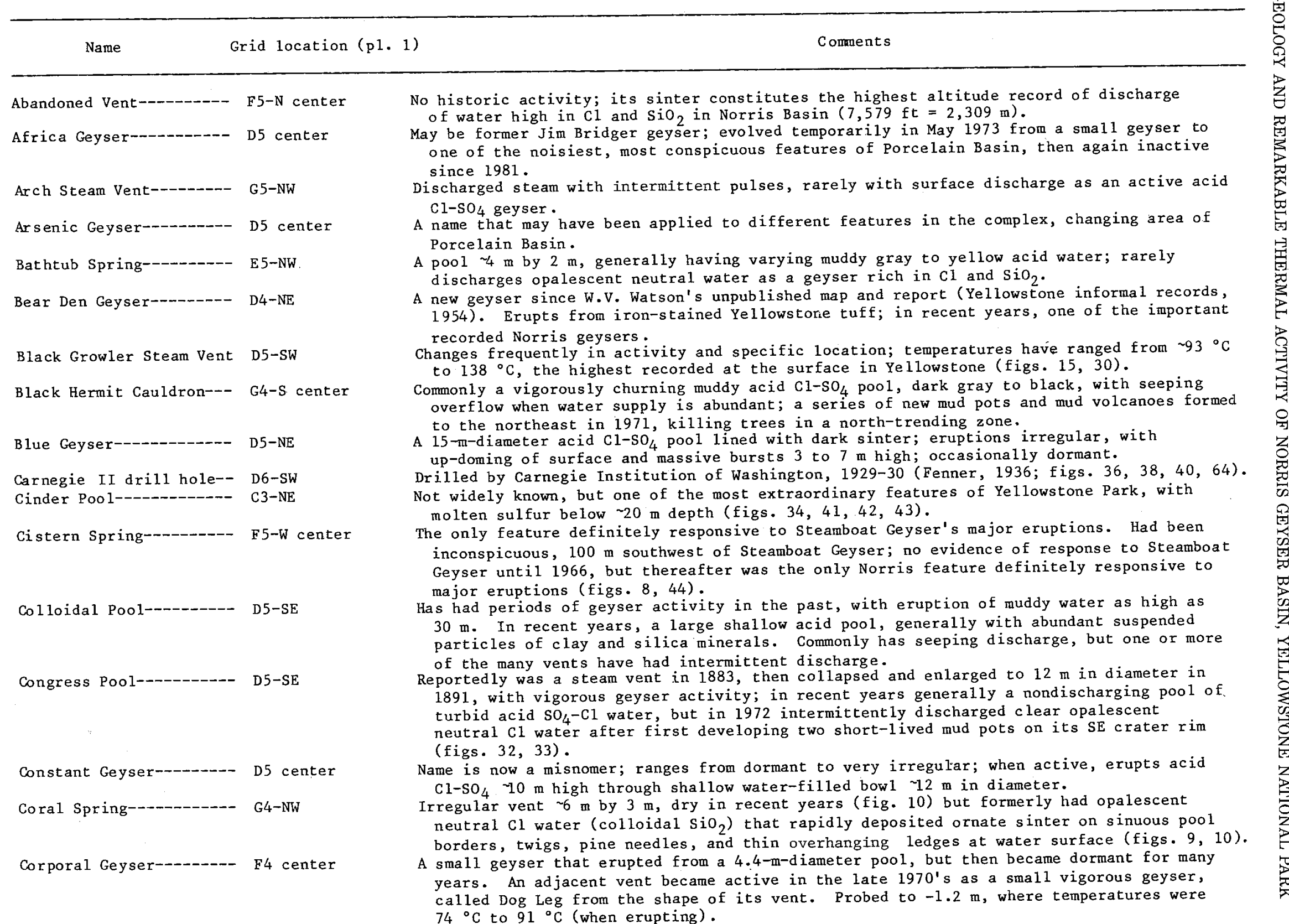


Crackling Lake Springs-- D4-SE

Crater Spring-----_---- F5-SW

Crown Jewels Springs---- D4-NE

Dark Cavern Geyser------ D5-SW

Decker Is land Geyser--.- F5-SW

Dishwater Spring------ F4-SE

Dr. Allen's Paint Pots-- E5-SW

Double Bulger--_-_-_-_ F4-SW

Ebony Geyser--.--_-..-- D4-NE

Echinus Geyser---_-_---- F5-SE

Emerald Spring---_-_---- E5-W center

Fan Geyser-

D5 center

Fearless Geyser-

F4-N center

Feisty Geyser--------- D5-E center

Firecracker Spring------ E3-NE

Gray Lakes------------ G4-SW

Green Dragon Spring----- G4-SW

Growler Spring-.----- C6-SW
Small thermal lake ( $\sim 43 \mathrm{~m}$ by $38 \mathrm{~m}$ ) bordered by springs and, at times, at least one small geyser on north shore and one or more on southwest shore.

Vigorous boiling undermined old sinter, resulting in chatic tilting of blocks; generally has 3 or 4 boiling vents; acid $\mathrm{Cl}_{-} \mathrm{SO}_{4}$ water level $\sim-1$ m but has discharged as a geyser for $\sim 2$ months in 1983 and again briefly in 1984.

Two related springs that have erupted as small acid $\mathrm{Cl}-\mathrm{SO}_{4}$ geysers, depositing gray, yellow, and brown spinose sinter and geyser eggs; recently less active to dormant.

Irregular behavior, commonly cyclic; some eruptions minor, others from 8-15 m. Has complex dark beaded sinter mound with several orifices. May have started in 1929 (fig. 37).

Generally, a large muddy acid $\mathrm{Cl}-\mathrm{SO}_{4}$ pool, $\sim 11 \mathrm{~m}$ by $6 \mathrm{~m}$, receiving discharge from Echinus Geyser; erupted in July 1967, possibly triggered by major eruptions of Steamboat Geyser.

Varying activity; at times discharges from 5-m-diameter acid Cl- $\mathrm{SO}_{4}$ pool into a large complex irregular shallow pool with many gas vents.

Named in 1927 for Dr. E.T. Allen of Carnegie Institution, Washington, D.C.; evidently less active than formerly, perhaps shifting $75 \mathrm{~m}$ to west.

Two vents $3 \mathrm{~m}$ apart, evidently both active in the $1880^{\prime} \mathrm{s}$; southwest vent now boils vigorously without discharge; northeast vent is a perfect flaring, sinter-lined funnel, now self-sealed, possibly vandalized ( $\mathrm{fig} \cdot 57$ ).

May have formed as a new spring about 1900, evolving to a geyser by 1926; thereafter active for many years, but varied greatly in interval from several hours to many days, erupting 3 to $25 \mathrm{~m}$ high from $1-\mathrm{m}$-diameter vent; dormant from vandalism since mid-1970's.

In recent years, one of the best known and most colorful of Norris geysers; at' times highly predictable but at others, highly variable to dormant, probably because of shallow mixing of neutral $\mathrm{Cl}$ and acid- $\mathrm{SO}_{4}$ waters (figs. 22, 23).

A beautiful yellowish emerald-colored acid $\mathrm{Cl}-\mathrm{SO}_{4}$ pool $14 \mathrm{~m}$ by $9 \mathrm{~m}$, sinter lined, with elemental $\mathrm{S}$ and deep water accounting for colors; generally boils vigorously, discharging at low but varying rates; has erupted violently, with surging and splashing 5 to $8 \mathrm{~m}$; gassy vents and small mud pots formed on northwest bank in 1971 . Probed to $-7.6 \mathrm{~m}$ by Manuel Nathenson, 6/18/74; maximum temperature at $-6.1 \mathrm{~m}, 104.2{ }^{\circ} \mathrm{C}$.

A small geyser, possibly named in the early 1930's, erupting for $\sim 5$ minutes to heights of about $8 \mathrm{~m}$.

An active geyser during early park expeditions, but for many years a boiling, nondischarging vent with fluctuations in water level; rim is dark spinose sinter typical of acid $\mathrm{C} 1-\mathrm{SO}_{4}$ waters. Probed $-7.6 \mathrm{~m}$ by White, $8 / 4 / 69$; maximum temperature $103.5^{\circ} \mathrm{C}$ at bottom.

A small geyser with nearly continuous eruption in the 1970 's, generally $1-3 \mathrm{~m} \mathrm{high,} \mathrm{in} \mathrm{an}$ area of numerous spouters and small geysers; not certain that the name has always applied to the same feature. Vent at adjacent areas flooded in early 1980's by opalescent silica-rich waters.

Extension of perpetual Spouter under Tantalus Creek; steam bubbles rise into creek sand and gravels and condense abruptly and audibly because of low gas content (other than steam).

Usually a gray-green turbid large hot pond with a narrow connection between two segments; many bordering springs and gas vents may supply acid $\mathrm{Cl}-\mathrm{SO}_{4}$ water by subsurface flow to Green Dragon.

A large colorful acid $\mathrm{Cl}-\mathrm{SO}_{4}$ spring with 3 aligned deep funnel-like vents having a common water surface, each generally boiling vigorously; the eastern vent is in a cavern that undercuts older Pinedale kame deposits; the cavern roof and sides are greenish yellow from Fe sulfates and $S$. At times the discharge from Green Dragon is almost as large as net Gray Lakes discharge, suggesting convective resupply to Green Dragon, augmented by heat and gases. Probed on $1 \mathrm{y}$ to $-1.2 \mathrm{~m}$, where temperature was $95.5^{\circ} \mathrm{C}$ ( $\mathrm{fig} .24$ ).

A pool about $6 \mathrm{~m}$ square in 1972-73, partly bounded by irregular walls of thoroughly leached Yellowstone tuff capped by thin sinter. Violently boiling yellow acid water has suspended $\mathrm{S}$; has discharged as much as $\sim 100 \mathrm{~L} / \mathrm{min}$ and deposited sinter in discharge channel from 1982 to 1983 disturbance. 
Guardian Geyser----.-- D5-SW

Ha rding Geyser

E5-NW

Hurricane Ven

Iris Spring (geyser)---- D5-NE

Ledge Geyser-_...-_-_._. D5-SW

Little Whirligig Geyser D5-W center

Locomotive Spring------- D5-SE

Medusa Spring--_-.--- $\mathrm{H} 3-\mathrm{NE}$

Minute Geyser--_-.------ E4-S center

Monarch Geyser Crater--- F4-NE

Mud Spring (geyser)--.-- G4-NE Mushroom Geyser-..--.--- E4-SE

Nuphar Lake----------- D6-SW One Hundred Spring Plain $\mathrm{C} 3-\mathrm{C} 4-\mathrm{B} 4$

Onyx Spring--_...-. D5-NE

Opal Spring-------- D6-NW

Opalescent Spring-_-_-_- C5-NW
Irregular acid $\mathrm{C} 1-\mathrm{SO}_{4}$ geyser emerging directly from ash-flow tuff, which has exhibited direct subsurface connections to valentine Geyser. When active, Guardian ejects water 6-10 m high at a low angle south into Valentine's alcove. Since about 1982 the geyser has sulfides in the mouth of its vent.

sulfides in the mouth of Generally a steam vent with no surface discharge but with vigorous subsurface boilin

A steep-walled rectangular vent $\sim 10 \mathrm{~m}$ by $5 \mathrm{~m}$ cut into Lava creek ash-flow tuff: at times surging and boiling vigorously with suspended matter, 3 to $4 \mathrm{~m}$ below general ground level.

A cluster of vents in the thickest sinter deposits of Norris Basin, nondischarging except during 1982-85. The south vent is actually two inaccessible vents below a bridge of sinter. North Hydrophane, accessible with difficulty, exposed $2.7 \mathrm{~m}$ of section (table 3 ) including pre-Pinedale(?) chalcedonic sinter. After 1982 widespread disturbance (table 8) aligned $\sim 250 \mathrm{~m}$ long on north-northeast trend, many new and old vents discharged 8) aligned escaping into Gray Lakes (figs. 17,45 ).

A 5 -m-diameter acid Cl-SO pool that erupts as a small geyser; dark brown near shallow margin, yellow brown near central vent.

A cluster of 5 vents in altered Lava Creek tuff, aligned along an enlarged northwesttrending fissure; main vent erupts an inclined column to the north while a vertical jet from another vent is as much as $20 \mathrm{mh}$ high. When active, Ledge is commonly Norris's most impressive geyser ( $\mathrm{fig}$. 14)

small geyser erupting from a $0.3 \mathrm{~m}$ vent in a shallow colorful pool; has short rapid bursts, generally 3 to $5 \mathrm{~m}$ high; intervals vary, commonly $\sim 1$ hour. Water is acid ( $\mathrm{ph}$ $\sim 3-1 / 2$ ), deposits minor Fe-bearing sinter (fig. 53).

Name probably applied in past to various nearby springs; Locomotive of plate 1 is $\sim 5 \mathrm{~m}$ by $7 \mathrm{~m}$, gassy, generally yellow from suspended $\mathrm{s}$, with minor discharge.

A colorful shallow basin $5.3 \mathrm{~m}$ by $6.6 \mathrm{~m}$, gassy with minor discharge; rim is yellow from native $S$, grading inward to yellow green near double vents. Erupted in 1984 at $11 / 2-$ to 2-hour intervals as high as $21 / 2 \mathrm{~m}$; duration $8-18$ minutes (Lee Whittlesey, oral commun., 1984).

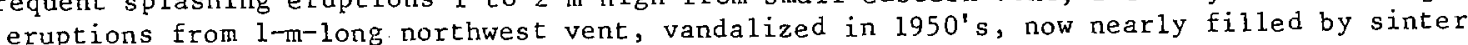
(fig. 46).

An early violent geyser, erupting 15 to $40 \mathrm{~m}$, but no recorded eruption since 1913. Main vent $\sim 3$ by $4 \mathrm{~m}$ in a large shallow basin; water is acid $\mathrm{Cl}-\mathrm{SO}_{4}$. An inconspicuous poo1, commonly turbid; erupted in 1957, 1967, 1971, and 1984.

Small geyser, erupting several times daily when active, but commonly buried by clastic debris from Emerald Spring drainage.

A cold undrained lake fed by atmospheric precipitation and minor thermal springs.

A large area with few notable springs but many gas seeps; treacherous, in part; largely a a shallow pond during high runoff, depositing opaline from Lava Creek tuffs.

A large blue-gray acid pool $\sim 6 \mathrm{~m}$ in diameter rimmed by iron-stained sinter; discharge A large blue-gray acid pool $\sim 6 \mathrm{~m}$ in diameter rimmed by iron-staine generally slight but at times rare geyser eruptions reported." with water ranging from neutral $\mathrm{Cl}$ to acid $\mathrm{Cl} 1-\mathrm{SO}_{4}$ and acid- $\mathrm{SO}_{4}$ types ( $\mathrm{figs} .7,31$ ).

nerthwesternmost spring observed to have opalescent blue color from colloidal $\mathrm{SiO}_{2}$ in neutral Cl water, but generally clear. 
Orpiment Springs-(spring)

Pearl Geyser-_-_-_-_-_- F4-SW

Pebble Geyser Cone------ F4-S center Perpetual Spouter------- E3-NE

Phillips Cauldron--_--- G4-W center

Pinto Geyser

D5 center

Pinwhee 1 Geyser--------- D5-NW

Porcelain Springs------ D6-W center

Porcelain Terrace------- D6-NW

Porkchop Geyser-_-_-_--- F4-SW (spring)

Primrose Springs-

D5-E center

Ragged Spouter

D5-E center

Realgar Springs-

$\mathrm{B} 4-\mathrm{NW}$

Receptacle Spring------- C4-SW

Recess Spring---_-_-_ F3-SE

Rock Spring-

C4 center

Root Pool

F5-SW

Sand Spring

$\mathrm{D} 5-\mathrm{NW}$
Seeps have deposited red and orange amorphous arsenic sulfides like Realgar Springs; mislocated by Hague and others (1904).

A shallow pool about $3 \mathrm{~m}$ in diameter palpitated by regular gentle bursts of gas, setting up concentric waves and slight pulsing discharge; has erupted to $\sim 1 \mathrm{~m}$ (Lee Whittlesey, or a1 commun., 1984).

An ornate sinter-fringed shallow basin $\sim 6 \mathrm{~m}$ in diameter, generally with pulsing discharge, of neutral $\mathrm{Cl}$ water rarely erupting 1 to $2 \mathrm{~m}$ high; bursts have been fairly frequent since 1983. Probed only to $1.1 \mathrm{~m}$ by white $8 / 4 / 69$; maximum temperature $92^{\circ} \mathrm{C}$, but fluctuating. Rapid siliceous sinter deposition inside pool rim since 1982 .

An important geyser during early explorations, erupting to $15 \mathrm{~m}$; now dormant and vandalized. Its name, from Hague and others (1904), is still appropriate, spouting neutral C1 water as high as $0.4 \mathrm{~m}$, indicating greater constancy than most Norris features; extension of its fissure under Tantalus Creek now called Firecracker Spring because of explosive condensation of steam bubbles, minor other gases.

Probably formed as a vigorous mud volcano ejecting debris of mud, sand, and gravel on rim; now an acid mud pot or muddy pool of varying consistency, depending on precipitation; the largest feature of its kind in Norris, with crater $\sim 3$ to $5 \mathrm{~m}$ in diameter. Probed $-2.4 \mathrm{~m}$, where temperature was $93.5^{\circ} \mathrm{C}$. Other small, short-1ived mud pots and mud springs formed to the north in seasonal disturbances in 1971 and 1972 , some of which evolved into silica-depositing springs (see table 8 ; fig. 47).

Small geyser active in recent years, depositing white sinter; may have evolved from a previously existing vent.

Frequently flooded by cold drainage from north. When active, erupts 5 to $10 \mathrm{~m} \mathrm{high}$ at intervals of 1 hour or less.

Recently applied as a group to ever-changing activity and rapid deposition of sinter at the southern base of Porcelain Terrace; many steam vents and spouters; pools commonly opalescent blue from colloidal $\mathrm{SiO}_{2}$ in neutral $\mathrm{Cl}$ water (figs. 6, 56).

An area of almost continuous change, commonly with contemporaneous changes in chemistry (figs. $6,7,48$ ).

An ornate small pool that deposits beaded sinter on margins and on twigs and pine needles. Generally seeping to intermittent quiet discharge but occasionally erupts as a geyser to $3 \mathrm{~m}$; water normally clear neutral $\mathrm{Cl}$ but rarely opalescent from colloidal $\mathrm{SiO}_{2}$. Narrow vent probed only to $0.6 \mathrm{~m}$; temperature $70^{\circ} \mathrm{C}$ to $90.5{ }^{\circ} \mathrm{C}$, varying with discharge. In continuous 3-6 m eruption (perpetual spouter) from a nearly empty crater from late March through June 1985 (figs. 11, 12, 13).

colorful pools of various colors and, at times, with several small neutral and acid spouters and geysers; some rapid deposition of sinter; colors related to $\mathrm{pH}$ and acid alteration products ( $\mathrm{silica}$ minerals, clays, Fe oxides; fig. 55).

Emerges through ragged break in sinter floor of Porcelain Basin. Almost continuous spouting since 1970.

Not precisely located on old maps, but best considered as low-temperature $\left(-45^{\circ} \mathrm{C}\right)$ seeps draining to Realgar Creek; orange and red coatings are amorphous $\mathrm{As}_{2} \mathrm{~S}_{3}$ (not orpiment and realgar, as claimed by Weed and Pirsson, 1891); has associated yellow sulfur.

A large shallow pool with margins changing greatly with precipitation and runoff; probably has little inflow of thermal water.

A large pear-shaped pool $-12 \mathrm{~m}$ long and as much as $11 \mathrm{~m}$ wide surrounded by forest; generally turbid, greenish acid $\mathrm{Cl}-\mathrm{SO}_{4}$ water, with seeping discharge; sulfur-lined mud floor

perforated by many small gas vents. Abundant spiny sinter deposits line the runoff channel.

Originally spring No. 91 of Peale (1883), then named in 1884 by Walter Weed (Lee Whittlesey, informal records). Formed from altered blocky Lava Creek Tuff surrounded by stunted pines; a vigorously boiling vent, generally not discharging.

An irregularly shaped pool with multiple boiling vents, generally with slight total discharge before 1983 disturbance. Erupted as a geyser in August 1967.

A shallow pool with multiple vents, formerly with one agitating its sandy bottom, but now dormant. 
TABLE 5.-Summary of notable thermal features, Norris Geyser Basin-Continued

\begin{tabular}{|c|c|c|}
\hline Name & Grid location ( $\mathrm{pl}$. & Comments \\
\hline Sieve Lake--- & C $5-\mathrm{SW}$ & $\begin{array}{l}\text { A shallow pond with many "holes" in its muddy bottom caused by gas discharge; supplied by } \\
\text { surface runoff, with little if any liquid thermal discharge; less active than formerly. }\end{array}$ \\
\hline Splutter Pot (geyser)--- & D5 center & $\begin{array}{l}\text { Frequently dormant; when active, belches a low discharge partly controlled by flow from } \\
\text { Pinwheel Geyser. }\end{array}$ \\
\hline Steamboat Geyser------- & F 5-NW & $\begin{array}{l}\text { The Finest geyser in Yellowstone's recorded history, with major eruptions as high as } \\
700 \mathrm{~m} \text { or higher in early years, then started another series in } 1977 \text { (see } \\
\text { frontispiece, fig. 16, and table 7). }\end{array}$ \\
\hline $\begin{array}{l}\text { Steam Valve Spring----- } \\
\text { (geyser) }\end{array}$ & E5 center & $\begin{array}{l}\text { One of the most closely observed geysers in Yellowstone's history; has had three cycles } \\
\text { of activity from birth, evolution, and demise (fig. } 35 \text { ). }\end{array}$ \\
\hline Sulfur Dust Spring & A4-S center & $\begin{array}{l}\text { An acid Cl-SO }{ }_{4} \text { spring lined and floored with abundant flocculent sulfur, temperature } \\
\sim 50{ }^{\circ} \mathrm{C} \text {, discharge }-15 \mathrm{~L} / \mathrm{min} \text { (fig. } 28 \text { ). }\end{array}$ \\
\hline The Reservoir-- & C3-E center & $\begin{array}{l}\text { A large warm pond at least } 13 \mathrm{~m} \text { deep, with a few inconspicuous warm vents on its south and } \\
\text { northwest margins; may rarely have surging variable discharge. May have formed by a } \\
\text { postglacial hydrothermal explosion but with debris rim now destroyed. }\end{array}$ \\
\hline Valentine Geyser------- & D5-SW & $\begin{array}{l}\text { Born on Valentine's Day, } 1907 \text {. A major geyser, commonly erupting acid } \mathrm{Cl}^{-\mathrm{SO}_{4}} \text { water } \\
\text { higher than } 30 \mathrm{~m} \text { when active; has been irregular and unpredictable, but at times very } \\
\text { predictable (fig. 15). }\end{array}$ \\
\hline Vermillion Spring & D5-SE & $\begin{array}{l}\text { Another name with a clouded, uncertain history related to changing activity and inadequate } \\
\text { location maps; applied to the group of acid-sulfate springs southwest to southeast of } \\
\text { Congress pool. Commonly one or more is red but others are orange, yellow, and yellow } \\
\text { green, related to differences in pH and oxidation states of Fe and } \mathrm{s} \text { (fig. 29). }\end{array}$ \\
\hline Veteran Geyser----- & F4 center & $\begin{array}{l}\text { A geyser with a complex vent and plumbing system; generally has minor eruptions but more } \\
\text { vigorous at times, possibly with a cyclic eruptive pattern. }\end{array}$ \\
\hline Vixen Geyser-- & F4-SW & $\begin{array}{l}\text { An interesting small active geyser that generally erupts in short explosive bursts, } \\
\text { generally } 1 / 2 \text { to } 5 \mathrm{~m} \text { high; most water drains back into its small rectangular vent. Rare } \\
\text { large eruptions as high as } 10 \mathrm{~m} \text { and longer in duration have been observed, with } \\
\text { considerable externa } 1 \text { discharge. A possible example of early official vandalism. Probed } \\
\text { to }-2.6 \text { m by White, } 8 / 4 / 69 \text {; maximum temperature } 97.5{ }^{\circ} \mathrm{C} \text { at bottom (fig. } 51 \text { ). }\end{array}$ \\
\hline Whirligig Geyser- & D5-W center & $\begin{array}{l}\text { A shallow basin } 10 \mathrm{~m} \text { in diameter with a small central cone containing a pipelike vent } \\
0.1 \mathrm{~m} \text { in diameter; commonly inactive when flooded by drainage from Constant Geyser, but } \\
\text { some evidence for greater activity in late summer; erupts acid } \mathrm{Cl-S0_{4 }} \text { water } 1 \text { to } 3 \mathrm{~m} \\
\text { high, rarely higher ( } \mathrm{mig} \text {. } 52 \text { ). }\end{array}$ \\
\hline Yel low Crown Crater----- & D4-E center & $\begin{array}{l}\text { Also called Crown Crater; formerly discharged, but has been dormant for many years; has a } \\
\text { circular, broad-rimmed cone } 0.2 \mathrm{~m} \text { high and } 1 \mathrm{~m} \text { wide. }\end{array}$ \\
\hline Yel low Funnel Spring--- & G4-NW & $\begin{array}{l}\text { Appropriately named during most of its history; has a colorful } 7-m-d i a m e t e r \text { flaring pool } \\
\text { with yellow-brown border, a yellow sulfur zone that grades to green in central vent. At } \\
\text { times water is turbid, lacking attractive colors. Probed to }-2.6 \mathrm{~m} \text {, where temperature } \\
\text { was } 92.8^{\circ} \mathrm{C} \text { (fig. } 27 \text { ). }\end{array}$ \\
\hline
\end{tabular}


TABLE 6.-Thermal features of Norris Geyser Basin known to have erupted as geysers

\begin{tabular}{|c|c|c|c|c|}
\hline Name & $\begin{array}{l}\text { Grid location } \\
\quad(\mathrm{pl} .1)\end{array}$ & $\begin{array}{l}\text { Height } \\
\text { (meters) }\end{array}$ & $\begin{array}{l}\text { Recorded } \\
\text { duration }\end{array}$ & Interval, if active; comments \\
\hline $\begin{array}{l}\text { Africa Geyser'- } \\
\text { Arch Steam Vent- }\end{array}$ & $\begin{array}{l}\text { D5 center } \\
\text { G5-NW }\end{array}$ & $\begin{array}{r}7-15 \\
10-24\end{array}$ & 3 min to days & $30 \mathrm{~min}$ to days $(1936-37,1971-81)$; dormant after 1981 \\
\hline Arsenic Geyser--- & D5 center & $1-5$ & $\begin{array}{l}\text { About } 5 \text { min (?) } \\
5-160 \mathrm{~min}\end{array}$ & $\begin{array}{l}\text { Rare; } 1968(1) ; 10 / 5 / 71(1) \\
\text { Several daily }\end{array}$ \\
\hline Basin Geyser-- & D5-SW & $1-5$ & Hours to days & Generally dormant but active in $1970-72$ \\
\hline $\begin{array}{l}\text { Bathtub Spring (geyser)----- } \\
\text { Bear Den Geyser-- }\end{array}$ & $\begin{array}{l}\text { E5-NW } \\
\text { D4-NE }\end{array}$ & $.5-1$ & $\begin{array}{l}\text { Not determined } \\
1 / 2 \text { to } 31 / 2 \mathrm{~min}\end{array}$ & $\begin{array}{l}\text { Not determined; active in } 1928,1968 \\
1-8 \text { hours }\end{array}$ \\
\hline Big Alcove Spring----- & H4-NW & $.3-6$ & Almost constant & Few seconds \\
\hline Black Pit Spring & F5-SE & $1 / 2-2 / 3$ & Hours to days & Rare; 1983 basin disturbance \\
\hline Blue Geyser- & $\mathrm{D} 5-\mathrm{NE}$ & $6-10$ & Hours to days & Several hours at times; generally active \\
\hline & $\mathrm{G} 4-\mathrm{NW}$ & 3 & Variable & Dormant \\
\hline $\begin{array}{l}\text { Carnegie II drill hole }{ }^{2}=-- \\
\text { Colloidal Pool- }\end{array}$ & $\begin{array}{l}\mathrm{D} 6-\mathrm{SW} \\
\mathrm{D} 5-\mathrm{SE}\end{array}$ & $\begin{array}{l}1 / 2-2 \\
5-30\end{array}$ & $\begin{array}{l}<15 \text { min } \\
\text { Up to } 20 \text { min }\end{array}$ & $\begin{array}{l}\text { Not determined; several vents have erupted since } 1968 \\
\text { Dormant }\end{array}$ \\
\hline Congress Pool (geyser) ${ }^{1}{ }^{2}---$ & D5-SE & $3-5$ & Varied & $\begin{array}{l}\text { Generally dormant as a geyser; normally a quiet or } \\
\text { turbulent pool }\end{array}$ \\
\hline $\begin{array}{l}\text { Constant Geyser-- } \\
\text { Corporal Geyser- }\end{array}$ & $\begin{array}{l}\text { D5 center } \\
\text { F4 center }\end{array}$ & $.8-6$ & $\begin{array}{l}10 \text { seconds } \\
3-6 \text { min }\end{array}$ & \\
\hline Crackling Lake Springs---- & $\begin{array}{l}\text { F4 center } \\
\text { D4-SE }\end{array}$ & $.3-1$ & $\begin{array}{l}3-6 \text { min } \\
\text { Uncertain }\end{array}$ & $\begin{array}{l}\text { Ir regular } \\
\text { Small geysers have been active, } N \text {. and } E \text {. shores }\end{array}$ \\
\hline Crater Spring--- & F5-SW & $1-10$ & $1 / 2-7 \mathrm{~min}$ & $6-18 \min (1983-1984)$ \\
\hline Crown Jewels Springs-------- & $\mathrm{D} 4-\mathrm{NE}$ & & & See table 5 \\
\hline $\begin{array}{l}\text { Dark Cavern Geyser }{ }^{1},{ }^{2}--- \\
\text { Decker Is land Geyser-- }\end{array}$ & $\begin{array}{l}\text { D5-SW } \\
\text { F5-SW }\end{array}$ & $\underset{\sim 9}{6-9}$ & $\begin{array}{l}1 / 4 \text { to } 4 \text { min } \\
10-12 \text { hours }\end{array}$ & $\begin{array}{l}\text { 15-26 min; genera } 11 y \text { active during recent years } \\
\text { Active on July } 24-25,1967\end{array}$ \\
\hline Dogs Leg Spring (geyser)---- & F4 center & $\sim 1 / 4$ & $9 \mathrm{~min}$ & $\begin{array}{l}\text { In formal name for feature } 15 \mathrm{~m} \text { NW. of Corporal } \\
\text { Geyser (F4 center); irregular }\end{array}$ \\
\hline 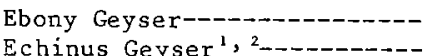 & $\mathrm{D} 4-\mathrm{NE}$ & 9 & 4 to $51 / 2 \mathrm{~min}$. & Now dormant due to vandalism \\
\hline $\begin{array}{l}\text { Echinus Geyser }{ }^{1}{ }^{2} \ldots \\
\text { Emerald Spring- }\end{array}$ & $\begin{array}{l}\text { F5-SE } \\
\text { E5-W center }\end{array}$ & $\begin{array}{l}6-30 \\
1-25\end{array}$ & $\begin{array}{l}3-12 \min (112 \mathrm{~min}, 1983) \\
\text { Varied }(1931-33)\end{array}$ & $\begin{array}{l}30 \text { to }>91 \mathrm{~min} \text {, but long intervals of dormancy } \\
\text { Rare; } 1931-33 \text {; now a dormant geyser but has boiled }\end{array}$ \\
\hline Fan Geyser---- & D5 center & $2-5$ & $4-7 \mathrm{~min}$ & $\begin{array}{l}\text { vigorously and discharged from SE. corner } \\
\text { Irregular and rare }\end{array}$ \\
\hline Fearless Geyser- & $\mathrm{F} 4-\mathrm{N}$ center & 8 & $15 \mathrm{~min}$ & Long dormant, generally nondischarging \\
\hline $\begin{array}{l}\text { Feisty Geyser- } \\
\text { Fireball Geyser- }\end{array}$ & $\begin{array}{l}\text { D5-E center } \\
\text { D5 center }\end{array}$ & $\begin{array}{l}4-10 \\
1-6\end{array}$ & $\begin{array}{l}1 / 2 \text { hour to }>6 \text { days } \\
8 \text { min to hours }\end{array}$ & $\begin{array}{l}\text { Irregular, hours to days; now dormant; see table } 5 \\
\text { Irregular, several times daily }\end{array}$ \\
\hline Glacial Melt Geyser-------- & D4-SE & $.6-1$ & Varied & Generally inactive \\
\hline Graceful Geyser- & C6-SW & $2-14$ & $5-9 \min (1983)$ & $\begin{array}{l}\text { Minutes to hours; first observed in } 1981 \text {, then active } \\
\text { again in } 1982 \text { in response to widespread changes; now } \\
\text { dormant }\end{array}$ \\
\hline Gray Lakes Springs------- & $\mathrm{H} 4-\mathrm{NW}$ & $.3-2$ & Nearly continuous & Nearly continuous \\
\hline $\begin{array}{l}\text { Green Dragon Spring }{ }^{2}=--- \\
\text { Growler Spring-- }\end{array}$ & $\begin{array}{l}\mathrm{G} 4-\mathrm{SW} \\
\mathrm{C} 6-\mathrm{SW}\end{array}$ & $\begin{array}{r}2-5 \\
.5-4\end{array}$ & $\begin{array}{l}\text { Minutes to hours } \\
\text { Hours to days }\end{array}$ & $\begin{array}{l}\text { Irregular, responded to Sept. } 1981 \text { disturbance (table } 8 \text { ) } \\
\text { Nearly continuous, seasonally }\end{array}$ \\
\hline Guardian Geyser----- & D5-SW & $3-15$ & $11 / 2-21 / 2 \mathrm{~min}$ & Irregular, responsive to Valentine Geyser \\
\hline Harding Geyser $1{ }^{2}-$ & $\mathrm{E} 5-\mathrm{NW}$ & $6-15$ & $5-10 \min (1966,1968$ and 1974$)$ & Irregular; 11-30 days, 1974 ; generally pulsed steaming \\
\hline Hurricane Vent----- & D5-SE & $2-2.5$ & Nearly continuous (1917) & $\begin{array}{l}\text { Now dormant, commonly with vigorous subsurface boiling } \\
\text { but no external discharge }\end{array}$ \\
\hline $\begin{array}{l}\text { Hydrophane Springs }{ }^{2}{ }^{2}------ \\
\text { Iris Spring---- }\end{array}$ & $\begin{array}{l}\text { G3-SE } \\
\text { D5-NE }\end{array}$ & $\begin{array}{l}.6-1 \\
.6-1-1 / 2\end{array}$ & $\begin{array}{l}\text { Minutes (1972) } 1982 ? \\
\text { Generally continuous }\end{array}$ & $\begin{array}{l}\text { Irregular; Sept. } 1972 \text { and } 1982 \text { disturbances (see table 5) } \\
\text { None recorded }\end{array}$ \\
\hline $\begin{array}{l}\text { Jetsam Pool- } \\
\text { Lava Pool- }\end{array}$ & $\begin{array}{l}\text { D5-SW } \\
\text { D5 center }\end{array}$ & $\begin{array}{l}2-10 \\
1 / 2-41 / 2\end{array}$ & $\begin{array}{l}\text { Not determined ( } 1970) \\
\text { Seconds to minutes }\end{array}$ & $\begin{array}{l}\text { Dormant since } 1970 \\
\text { Irregular; function exchanges with numerous vents }\end{array}$ \\
\hline
\end{tabular}


TABLE 6.-Thermal features of Norris Geyser Basin known to have erupted as geysers-Continued

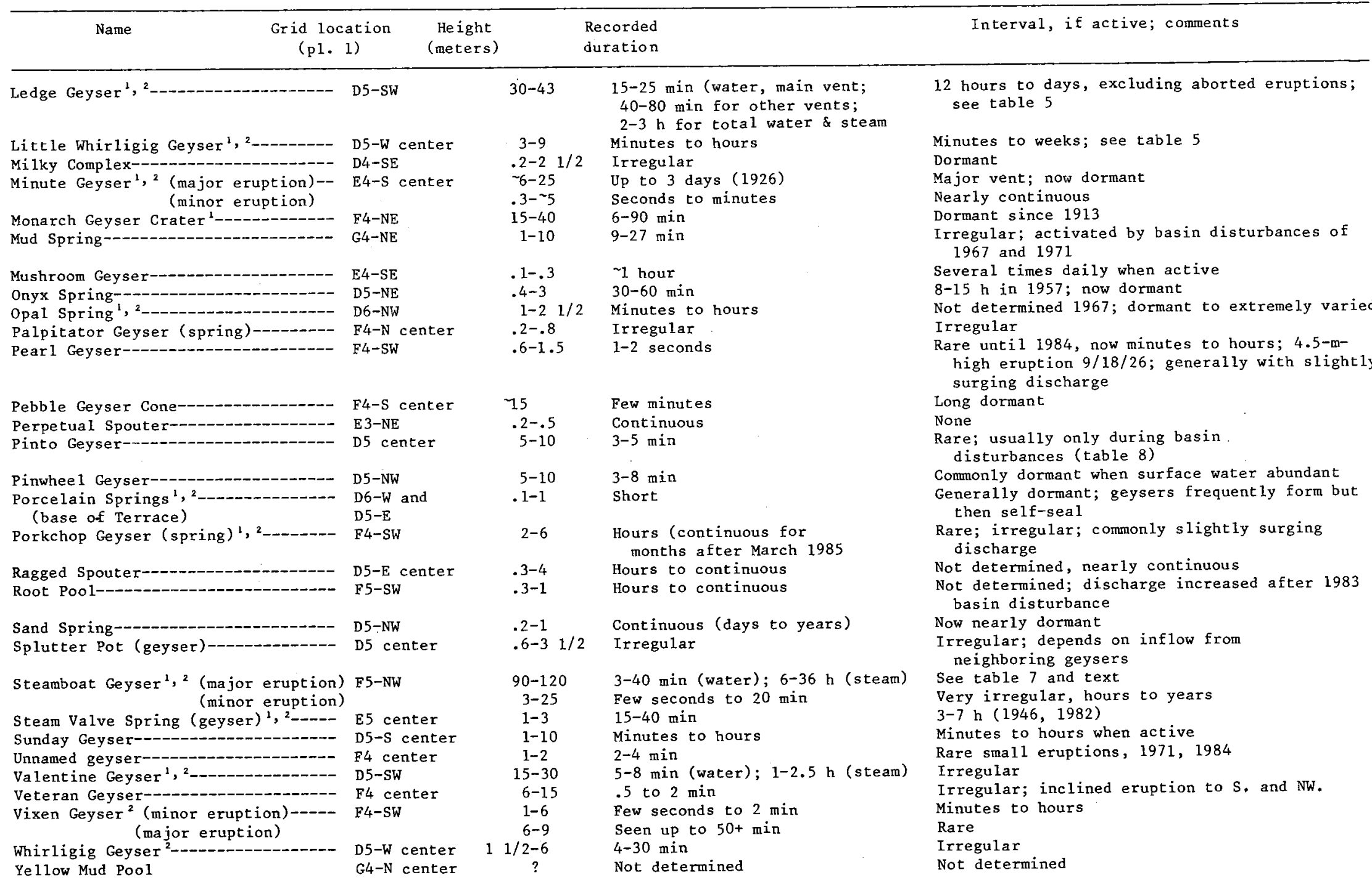

(Total, at least 70 recorded geysers, with many others not specifically recorded, as on southern crest of Porcelain Terrace) 


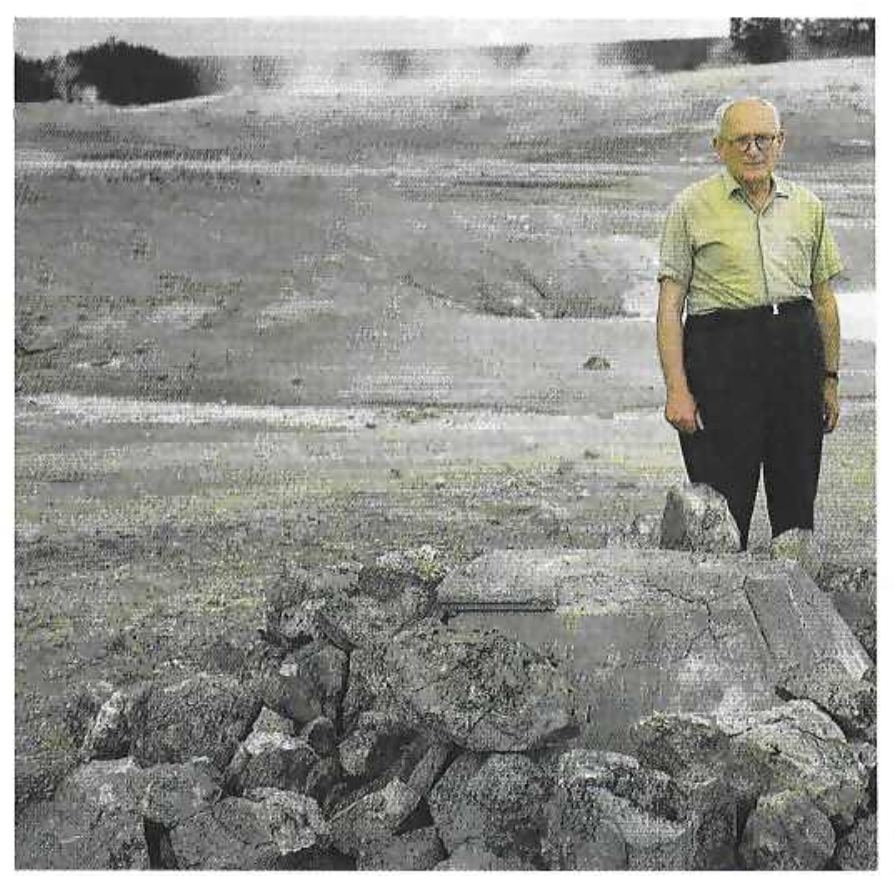

FIGURE 36.-Concrete monument and rocks to stabilize Carnegie II drill hole (pl. 1, D6-SW; previously called "Norris" drill hole by Fenner, 1936), the world's second research hole drilled in a geothermal area. Vapor from cone of Congress Pool is in upper left; note absence of all vegetation in immediate vicinity. Photographed September 10, 1967, with Dr. A. Steiner of New Zealand, one of the earliest petrologists of active hydrothermal alteration.

\section{AFRICA GEYSER}

Africa Geyser (pl. 1, D5-SW) was given its name in 1968, evidently because of its shape as viewed from the southwest. It may also have been active in the late 1930's as "Jim Bridger Geyser"; alternatively it may have formed from some other new or old vent. So many vents exist in Norris Basin, changes are so frequent, and maps have been so inadequate that the history of a specific vent that evolved through dormancy may be impossible to determine with certainty.

From 1968 to 1971, Africa Geyser was intermittently active as a small geyser, but early in 1971 eruptions became more vigorous, enlarging its throat. In a normal major eruption, water was ejected in a pulsating series of bursts that angled slightly to the northeast, usually 6 to $10 \mathrm{~m}$ high, but with a few single bursts to $15 \mathrm{~m}$.

In August 1973, Africa Geyser increased even more in vigor and changed from intermittent eruptions (durations of 5 to 10 minutes, intervals of 60 to 80 minutes) to continuous eruption as a violent, noisy, perpetual spouter. By 1975 , it was again normally a geyser, frequently with long-sustained eruptions reminiscent of its 1973 activity.
A spectacular result of Africa Geyser's nearly continuous forceful jetting of steam and fine spray during the winters of 1973-79 were ice cones up to $4.5 \mathrm{~m}$ high that formed as much as $30 \mathrm{~m}$ to the northwest. Each midwinter, the largest cone extended as a natural bridge over the warm tributary of Tantalus Creek.

In January 1981 a new vent formed about $2 \mathrm{~m}$ southwest of Africa Geyser's main orifice. The uppermost sinter sheets were ruptured and shattered around the new vent, in total area then about $7 \mathrm{~m}$ by $5 \mathrm{~m}$, and small fragments of pyrite were ejected to the surface. The new vent was dominant for the next four months until June 2, 1981, when the flow of thermal fluids evidently shifted $55 \mathrm{~m}$ south to Colloidal Pool and Sunday Geyser, instigating major 10 - to 15 -m-high erosive eruptions from Sunday Geyser. Africa and Sunday Geysers were definitely interconnected, as shown by a drop in water level of more than $40 \mathrm{~cm}$ in Africa's inactive vents at the start of each of Sunday's eruptions. Within a few weeks Africa Geyser became totally inactive, and it now functions as a low-temperature drain for springs upslope.

\section{BLACK GROWLER}

The name Black Growler (pl. 1, D5-SW) applies to a succession of related steam vents and fumaroles (actually, a changing complex) on and near the southwest rim of the alcove eroded into Lava Creek Tuff by Valentine Geyser, or its predecessors. At least five different steam vents or fumaroles on this steep alcove rim have been called Black Growler at various times (Allen and Day, 1935, fig. 8; also figs. 15, 30, and 37 of this report). One or more vents have usually discharged steam at any one time, but one has generally been more conspicuous than the others. During many seasons, however, even the most vigorous was not highly conspicuous, having a temperature generally close to boiling for the altitude (approximately $92.4^{\circ} \mathrm{C}$ ), with water droplets ejected at times with steam. During other seasons, however, the strongest of several vents noisily ejected steam at high pressure, when temperatures above $100{ }^{\circ} \mathrm{C}$ were generally observable; the highest recorded temperature was $138.3^{\circ} \mathrm{C}$ (Allen and Day, 1935, p. 35).

On September 19, 1947, D.E. White obtained a measurement of $109.5^{\circ} \mathrm{C}$ in a vigorous fumarole called Black Growler by Norris naturalists, but probably above and east of the feature photographed by Allen and Day (1935, fig. 8). Thereafter, temperatures observed by Norris naturalists were commonly near $93^{\circ} \mathrm{C}$ (about boiling), but $106.7^{\circ} \mathrm{C}$ was noted in 1955 and 104.4 to $124{ }^{\circ} \mathrm{C}$ in five different vents in 1961. Some naturalists suspected that temperatures were controlled in part by local water supply, being higher in dry years and lower in wet years 


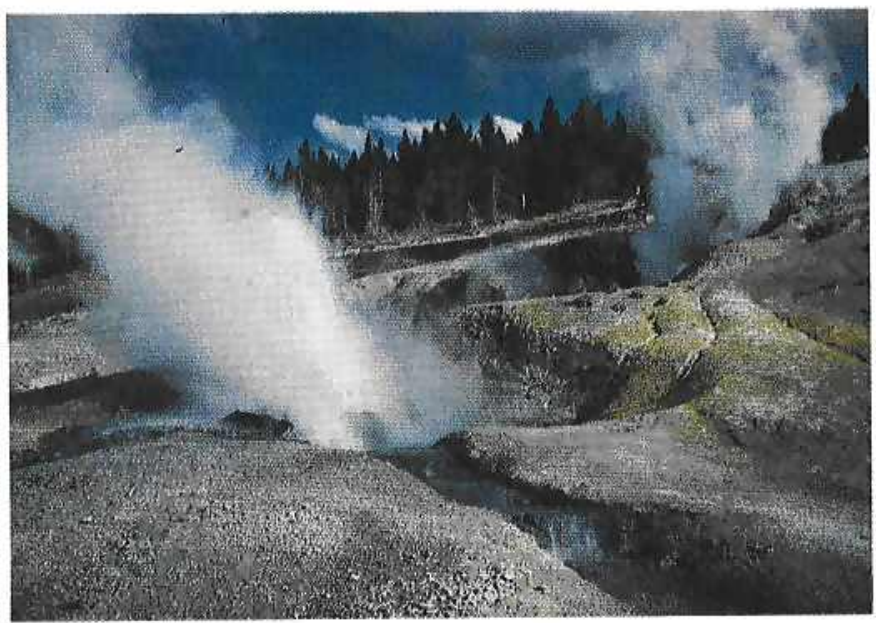

FIGURE 37.-Dark Cavern Geyser (pl. 1, D5-SW), looking east to Black Growler fumarole (right) and dead trees south of Congress Pool (distant center). Note dark color (FeS in sinter) in Dark Cavern's channel and acid splash zone. Width of near channel is about $0.4 \mathrm{~m}$. Photographed September 3, 1954.

and after heavy rains. As with so many changes in activity at Norris, supporting data are too qualitative and sporadic to prove suspected changes in water supply.

\section{CARNEGIE II DRILL HOLE}

Carnegie II drill hole (pl. 1, D5-SW), called "the bore hole in Norris Basin" by Allen and Day (1935) and Fenner (1936), is now known by the more distinctive name Carnegie II. It was drilled in 1929 and 1930 by the Geophysical Laboratory of the Carnegie Institution of Washington (Allen and Day, 1935, p. 473-475; Fenner, 1936; fig. 36) and was only the second hole in the world drilled for scientific purposes in natural thermal areas (the first, now called Carnegie I, was drilled in 1929 in the Upper Geyser Basin). The Carnegie scientists desired a "typical acid area," preferably near superheated fumaroles such as Black Growler to test their hypotheses relating springs and fumaroles to superheated volcanic emanations, availability of ground water, chemistry of geothermal fluids, and hydrothermal alteration products.

Fenner's physical data from this hole and his dramatic experiences while drilling into such a hostile environment are well described (Fenner, 1936, especially p. 282-287). His interpretations and conclusions have been modified by us in the light of recent experience in exploring hotspring areas for geothermal energy (White and others, 1975 , p. 57-63).

The hole was drilled to $-80.9 \mathrm{~m}(265 \mathrm{ft})$, but drilling problems increased rapidly below $61 \mathrm{~m}(200 \mathrm{ft})$. At -74.3 $\mathrm{m}$ (243.6 ft), a temperature of $159^{\circ} \mathrm{C}$ was measured. Six days later, after encountering many problems from escaping fluids, $205^{\circ} \mathrm{C}$ was observed at $-75.3 \mathrm{~m}(246.5 \mathrm{ft})$, only $1 \mathrm{~m}$ deeper. In the meantime, observed wellhead pressures increased dramatically from $\sim 9 \times 10^{5}$ to $>20.5$ $\times 10^{5} \mathrm{~Pa}$ ! The latter pressure, if reliable, requires subsurface temperatures of about $215^{\circ} \mathrm{C}$. White and others $\left(1975\right.$, p. 59) concluded that the observed $159^{\circ} \mathrm{C}$ at -74.3 $\mathrm{m}$ was relatively close to predrilling ground temperatures, but the rapid increase to $205^{\circ} \mathrm{C}$ (or $>215^{\circ} \mathrm{C}$ ?) resulted from upflow of hotter fluids into the drill hole (fig. 2).

Depth from ground surface to the underlying water table was not recorded but was probably close to $4 \mathrm{~m}$, or near the base level established by Nuphar Lake (White and others, 1975, p. 60; pl. 1, D6-SW). The drill core from this level was strongly acid-leached (see section "Rocks and Alteration Mineralogy of Drill Holes, Norris Geyser Basin"), indicating a near-surface zone leached by $\mathrm{H}_{2} \mathrm{SO}_{4}$. With deeper penetration, the water almost certainly changed downward to an acid $\mathrm{Cl}_{-} \mathrm{SO}_{4}$ water body (perhaps thin) that decreased downward in acidity and supplied the mixed water and vapor discharged from the hole and nearby vents during later drilling.

The following discussion concerns natural and induced changes that occurred near the Carnegie II drill site since 1929. By present geothermal standards, the site selected for the hole would have been recognized as highly unstable and hazardous. ${ }^{2}$ The drill-hole casing and cementing procedures were clearly inadequate. The casing eventually ruptured at $-11 \mathrm{~m}$, and blowouts appeared in adjacent ground in at least three directions at distances as great as $25 \mathrm{~m}$ from the drill hole (Fenner, 1936, fig. 10), indicating local changes of at least a temporary nature. After drilling terminated, 5 tons of cement were forced into the hole in an attempt to return the area to its former condition. The old records are not sufficiently detailed to compare original natural activity with postdrilling activity, or whether changes were temporary or permanent. Because nearly all parts of Norris Basin undergo both gradual and abrupt natural changes of various kinds, such an assessment is not easily made.

However, the immediate drill site seemed relatively stable when D.E. White first visited Norris Basin in 1947. At that time the chemical nature of springs close to Carnegie II was of special interest to him. All of these springs were of the acid-sulfate type, low in chloride. The nearest high-chloride spring was Congress Pool, $65 \mathrm{~m}$ west of the drill hole (pl. 1, D5-SE; figs. 32, 33). During White's irregularly spaced and generally hurried visits from 1947 to 1965 , some changes in color and vigor of

${ }^{2}$ This must not be interpreted as a criticism of Carnegie scientists; they were pioneers in the research drilling of hazardous geothermal areas with very high near-surface temperatures and fluid pressures; also, drilling technology of the time was primitive. 
boiling were occurring in the acid-sulfate springs west, southwest, and south of the drill hole (including those shown in fig. 29), but springs with the appearance and physical properties of neutral chloride waters (appreciable discharge, active deposition of sinter, and opalescent-blue color of colloidal silica) were absent except in Congress Pool during one of its rare periods of overflow (fig. 33).

This situation of relative stability near Carnegie II continued through the autumn of 1967 , but the area to the east was steaming by late September (fig. 38 ) and then started to change near the monument at some unknown time during the winter or spring of 1967-68. The concrete monument constructed on the drill-hole site by Fenner's crew (figs. 36,38 ) had remained unchanged through late 1967. Figure 38 shows the area about a week before a boiling or overpressured interconnection could have been established from drill hole Y-9, which was being drilled $130 \mathrm{~m}$ to the south-southwest (pl. 1, E5-NE; fig. 39; White and others, 1975, p. 52-55).

When the Carnegie II site was visited by White on May 27, 1968 (fig. 40), a vigorously boiling vent had broken out at the monument's western base, and water was discharging at a rate of 2 to $3 \mathrm{~L} / \mathrm{min}$. Ten days later, the discharge was still about the same, but ground as far as $60 \mathrm{~m}$ south and southeast of the drill hole was heating up-or had already heated up-sufficiently for most lodgepole pines to be dying. These had been stunted pines about 3 to $7 \mathrm{~m}$ high, previously stressed by moderately high acidity and soil temperatures, but by the spring of 1968 they were being subjected to intolerable environments.

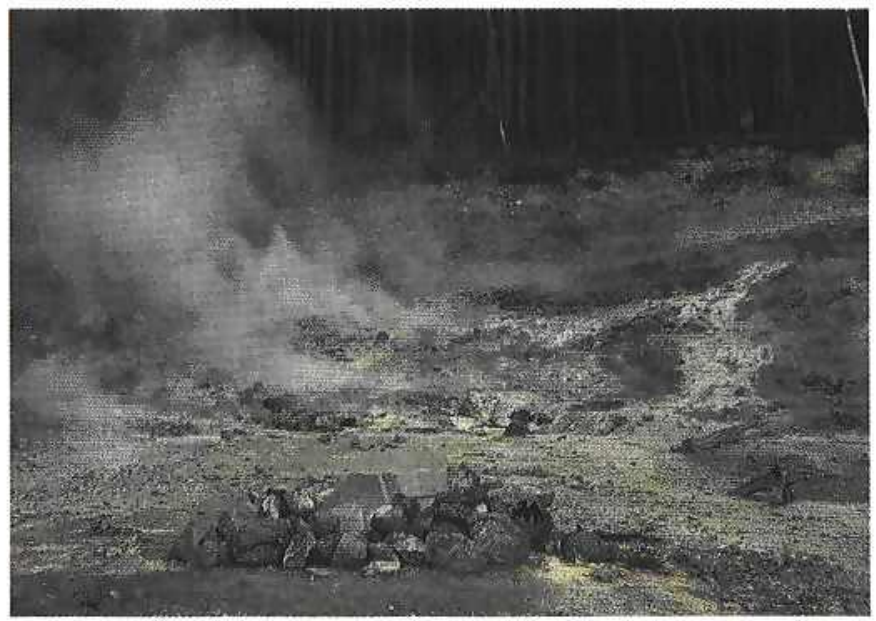

FIGURE 38.-Steaming ground 10 to $20 \mathrm{~m}$ southeast of Carnegie II drill hole (pl. 1, D6-SW), five days before boiling temperatures and water overpressures were first measured in research drill hole Y $-9,130 \mathrm{~m}$ to the south-southwest, on October 5, 1967 (see text; White and others, 1975 , p. 52-55). Note that no visible fluids were escaping near the Carnegie II monument. Photographed September 30, 1967.
All trees were either dead or dying, and many had been blown down to the east by high winds. By June 18, discharge from the west base of the monument was estimated at 3 to $4 \mathrm{~L} / \mathrm{min}$. New small springs approximately $5 \mathrm{~m}$ south-southeast of Carnegie II were discharging water at a total rate of 10 to $15 \mathrm{~L} / \mathrm{min}$, and several of these for the first time were depositing siliceous sinter from opalescent high-silica water, thus indicating upflow of nearly neutral chloride water into formerly acidic ground, in contrast to the acid-sulfate waters of other nearby springs (fig. 29).

Were any of these changes natural, or were they all related to the drilling of U.S. Geological Survey research

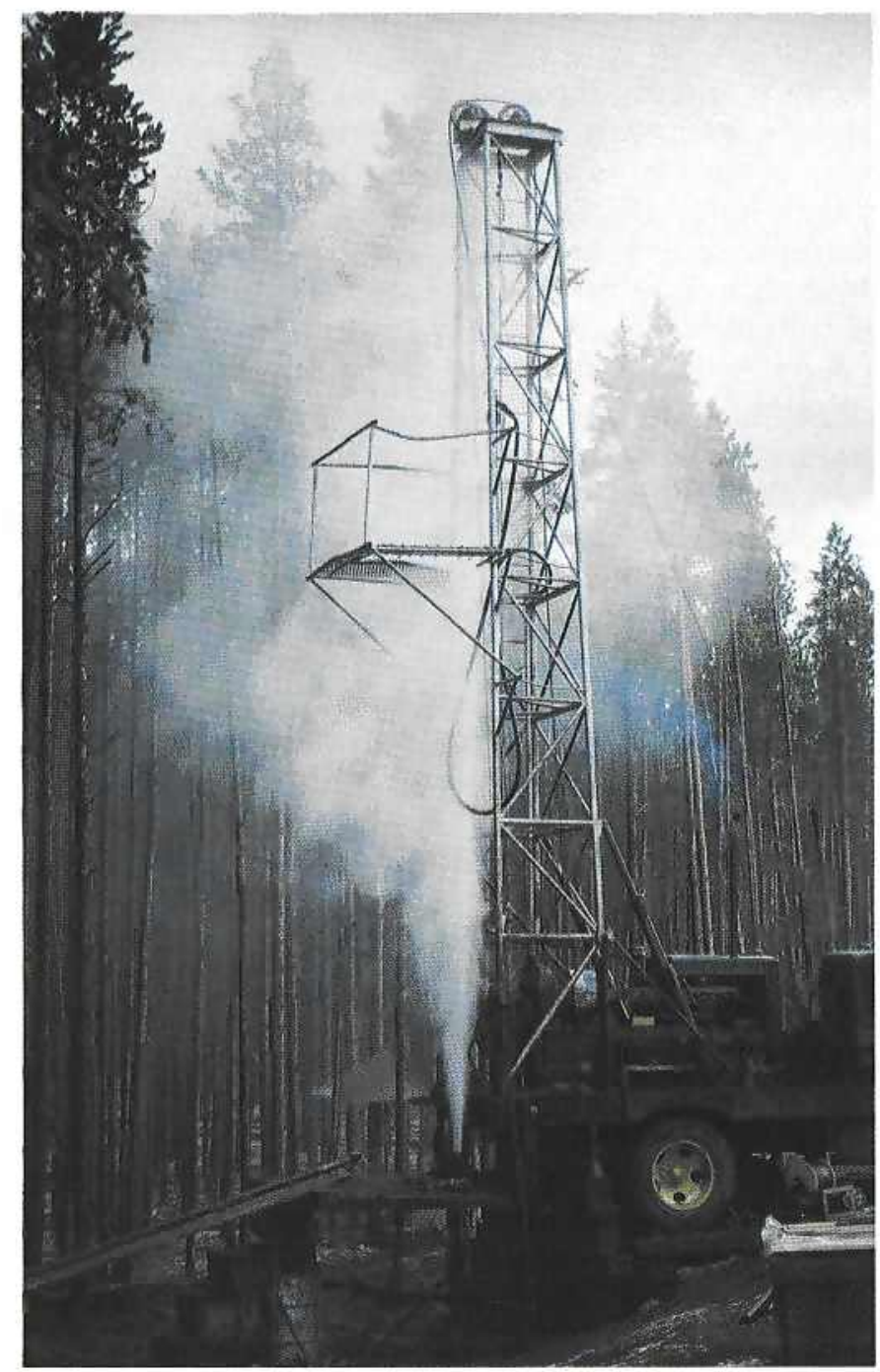

FigURE 39.-Y-9 drill hole (pl. 1, E5-NE) after core barrel was withdrawn from $-210 \mathrm{~m}$ on October 14, 1967. Gassy behavior of Y-9 at depths below $60 \mathrm{~m}$ was clarified only after a temperature profile was measured on June 10,1968, confirming changes that had occurred since this initial depth was first penetrated by drilling (White and others, 1975 , p. 52-54, figs. $27-28$ ). 


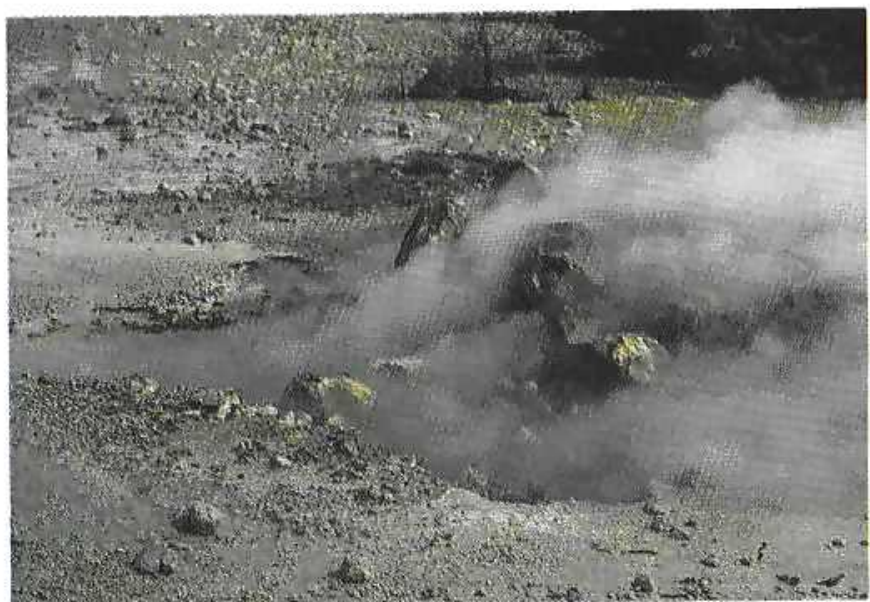

FIGURE 40.-Carnegie II monument when first observed on May 27, 1968 , by D.E. White, after new activity had broken out during the previous winter Compare with figures 36 and 38.

drill hole Y-9 the previous October? Due to the proximity of drill hole Y-9 to Carnegie II, we concluded that changes induced by the drilling of Y-9 probably caused delayed responses in Carnegie II. Even though these changes could have been coincidental in view of the frequent natural changes that characterize Norris Basin, we pumped several tons of cement slurry into Y-9 on September 24, 1969, thereby losing a valued observation hole; however, we are not certain that cement completely filled the hole, especially near the critical depth of $-60 \mathrm{~m}$. The possible cause-and-effect relation would have been confirmed if activity near Carnegie II had decreased or ceased soon after Y-9 was cemented. This did not occur, although activity stabilized and may have decreased a little by September 1971, when discharge at the base of Carnegie II's monument was about $3 \mathrm{~L} / \mathrm{min}$ and discharge of the sinter-depositing springs to the southeast was only 4 to $6 \mathrm{~L} / \mathrm{min}$. At a later time (approximately 1977 or 1978) the cement monument over the well began to pulsate with movement perhaps as much as $1 \mathrm{~cm}$ (estimated by R.A. Hutchinson), so slow changes evidently were still occurring.

\section{CINDER POOL}

The fascinating but little-known spring Cinder Pool is in the western part of Norris Basin (pl. 1, C3-NE) and is one of the more remarkable thermal features of the park. This nearly circular pool, about $9 \mathrm{~m}$ in diameter, contains milk-white to gray water, and its surface is generally 30 to 75 percent covered by floating black "cinders" ranging from irregular shapes to spherical particles $\sim 1 \mathrm{~mm}$ to $>5 \mathrm{~mm}$ in diameter (figs. 34,41 ). A few "cinders" are

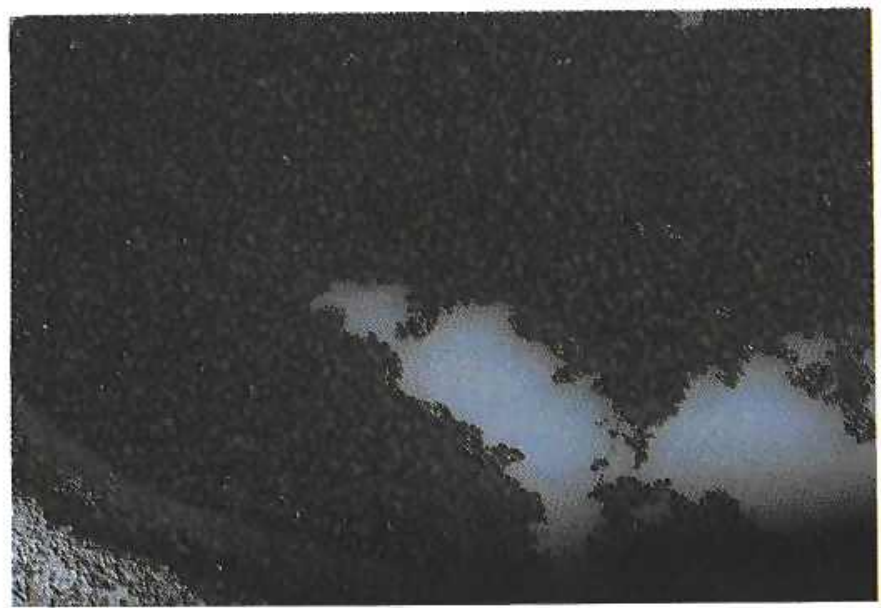

Figure 41.- "Cinders" of Cinder Pool. Origin was unknown until 1969, when temperature profiles (fig. 42) were measured (see subsection "Cinder Pool" for details). All floating "cinders" were black in 1969 (fig. 34), but by September 1984 (this photograph, each $\sim 1 \mathrm{~mm}$ in diameter) about 35 percent were golden in reflected light (for unknown reasons, Fe sulfide was dispersed in only about two-thirds of the "cinders").

nearly perfect spheres with hollow centers, but most are irregular, with at least one broken surface that reveals a central cavity. The thickest walls also contain dispersed small spherical cavities of various diameters, similar to the spherical gas cavities (vesicles) of some volcanic cinders and lava flows of fluid basaltic pahoehoe types. Some cinders as long as $10 \mathrm{~cm}$ float as irregular "clinkers." Allen and Day (1935, p. 483) identified the black "cinders" as elemental sulfur colored black by finely dispersed pyrite. A few "cinders" with golden reflectance not previously noted (fig. 41) may either have thin coatings of pyrite or are elemental S. When dried, the "cinders" burn freely with a strong $\mathrm{SO}_{2}$ odor.

Yellow sulfur forms in many acid springs of Norris Basin, but black spherules of sulfur are not known elsewhere in the United States. Numerous early observers were curious about these "cinders," but their origin remained enigmatic until 1969.

On August 4, 1969, D.E. White and seasonal naturalist Ed Leigh probed the pool for temperature-depth data (shown on fig. 42). Temperatures increased rather regularly from the surface $\left(89.8^{\circ} \mathrm{C}\right)$ to $-11.6 \mathrm{~m}$, which is near the deepest probe previously recorded (Allen and Day, 1935, p. 483). The thermistor probe and attached lead weight hung up temporarily near this depth, but they were eventually freed and lowered to $-18.3 \mathrm{~m}$, where $94.0^{\circ} \mathrm{C}$ was measured on a "mushy" bottom similar to sand or silt. Previous experience in probing thermal vents had shown that persistent efforts sometimes revealed a 
deeper channel beneath an apparent "floor." After a few minutes of probing, a deep entry actually was found, but the probe and its lead weight failed to fall freely. Instead, they were lowered sluggishly down through some resistant material that behaved like uncompacted mud or silt. At $-19.2 \mathrm{~m}$ the temperature had risen to $96^{\circ} \mathrm{C}$ and then rose abruptly to $117.5{ }^{\circ} \mathrm{C}$ at $-20.4 \mathrm{~m}$. The probe continued to behave as if suspended in a very viscous medium. No explanation for this unusual behavior was evident until the probe was withdrawn from $-21.3 \mathrm{~m}\left(119.5^{\circ} \mathrm{C}\right)$ and was found to be completely encased in a black pitchlike substance (fig. 43) that hardened and was later found to be elemental sulfur colored by dispersed iron sulfide similar in composition to the surface cinders but very different in appearance. The bottom of this pool evidently contained a pot of molten sulfur overlain by a porous zone of congealed fragments of sulfur! Also, the cable was encased in congealed sulfur for about $2 \mathrm{~m}$ above the probe.

In standard references, the melting point of orthorhombic sulfur is listed as $112.8^{\circ} \mathrm{C}$, and of monoclinic sulfur, $119.0^{\circ} \mathrm{C}$. However, molten sulfur can also be undercooled to a black rubbery substance (metastable glass?) at temperatures below both melting points.

The data of August 4,1969, and the later thermistor series of September 24 (fig. 42) suggest a deep concealed "kettle" of seething, convecting molten sulfur at depths below about $19 \mathrm{~m}$ overlain by hot acid $\mathrm{SO}_{4}$-Cl water convecting through fragments of sulfur. A dense "lid" or

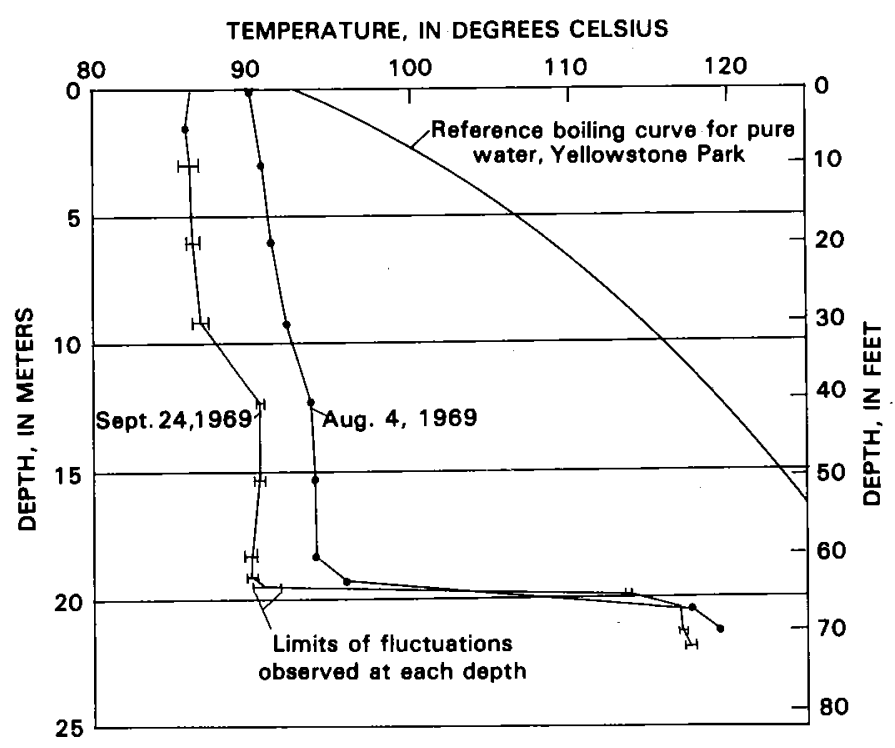

Figure 42.-Temperature-depth measurements from Cinder Pool, Norris Geyser Basin, August 4 and September 24, 1969. Lower temperatures in September were probably responding to decreased air temperatures. viscous zone of elemental sulfur not easily penetrated by the probe probably exists under most of the surface pool at depths of 19 to $20 \mathrm{~m}$. This zone is overlain by $\sim 1 / 2 \mathrm{~m}$ of sulfur sediment-probably particles similar to the floating "cinders" except with lower porosity and higher density. We assume that at one or more places the sulfur "lid" is intermittently pierced by streams of rising gas bubbles that buoyantly carry molten sulfur into the cooler overlying water-saturated porous zone. The gases probably exist in part as separate vapor bubbles, but may also be in solution in the molten sulfur. The hollow "cinders" might be interpreted as sulfur precipitated on gas bubbles but are more likely to be rapidly chilled blobs of molten sulfur containing dissolved gases that exsolve and expand as long as the undercooled sulfur glass is sufficiently low in viscosity.

The second thermistor series (Sept. 24; fig. 42) revealed a profile of slightly lower temperatures, probably in response to the lower air temperatures and stronger winds of autumn. Differences in temperature within the molten sulfur body may be due in part to differences in convective transfer of heat to the cooler overlying water and perhaps also to differences in behavior at specific points of entry penetrated by the probe.

Why does molten sulfur form in Cinder Pool but has not been identified elsewhere in the United States? The only comparable occurrences we are aware of are in Japan and New Zealand. In the large Oyunuma Crater Lake of Noboribetsu, Japan (Murozumi and others, 1966; Abiko, 1971), molten sulfur near $120^{\circ} \mathrm{C}$ occurs at depths below $12 \mathrm{~m}$, underlying acid chloride-sulfate waters as in Cinder Pool. In Oyunuma, the sulfur is mined by dredging the bottom of the lake. Black "cinders" have also been observed at Waiotapu, New Zealand (Lloyd, 1959, p. 155-159). This locality is similar in its abundant acid

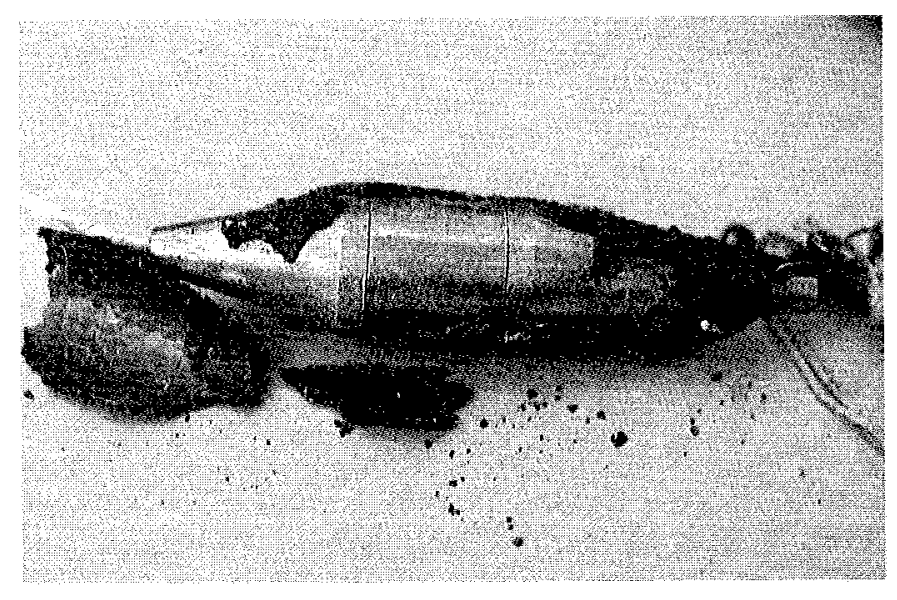

FIgURE 43.-Thermistor probe after withdrawal from Cinder Pool on August 4, 1969 (see temperature profiles, fig. 42). Probe $\sim 4$ in. long had penetrated a molten "pot" of elemental sulfur that congealed on the probe and cable during withdrawal. 
$\mathrm{Cl}-\mathrm{SO}_{4}$ waters and the appearance of black "cinders." Temperatures as high as $300^{\circ} \mathrm{C}$ have been measured in Waiotapu's deep drilled wells, but Lloyd has not reported a temperature profile in the cinder-producing pools.

The most critical requirements for the formation of molten sulfur and "cinders" in these localities are probably: (1) abundant supply of $\mathrm{H}_{2} \mathrm{~S}$ (the basic source of reduced sulfur in geothermal areas, and particularly abundant in Norris Basin); (2) a high-temperature vertical vent, sufficiently deep and accessible so that temperatures of at least $120^{\circ} \mathrm{C}$ and coexisting in liquid and vapor can be

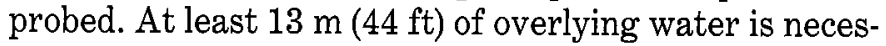
sary to provide the pressure required for temperatures of $120^{\circ} \mathrm{C}$ to exist in a saturated water-steam system; less than 10 percent of the vents probed in Yellowstone Park have such free vertical clearance, and of these, only Cinder Pool and Steamboat Geyser are in Norris Basin; (3) $\mathrm{H}_{2} \mathrm{~S}$ oxidizing to elemental sulfur as a major product, most simply by surface oxidation of an $\mathrm{H}_{2}$ S-rich convecting pool; elemental sulfur is conspicuous below water level in some slightly to strongly acid springs of the park (as shown in figs. 27 and 28); and (4) rate of discharge low enough to avoid flushing and removal of newly formed sulfur.

Of all thermal features we know in Yellowstone Park, Cinder Pool is the only one that satisfies all these requirements. Its highest recorded surface temperatures (in gassy upflow) have ranged from 92 to $84^{\circ} \mathrm{C}$, but somewhat cooler temperatures always occur on pool margins; its $\mathrm{pH}$ has generally ranged from 3.8 to 4.2 . Perhaps critical is the fact that its water level is generally a few centimeters below overflow, although discharge of a few liters per minute has been observed. Presumably when water containing a thick suspension of elemental sulfur convects down to the sediment surface near $-19.2 \mathrm{~m}$, elemental sulfur mixes with chilled or water-logged cinders that are too heavy to float, and then settles out. The deposit thickens enough for conductive and convective heat to raise temperatures to $115^{\circ} \mathrm{C}$ or more, when insulated basal layers of cinders presumably melt and are reincorporated in the deeply convecting molten sulfur, with convection being aided by escaping gases.

\section{GISTERN SPRING}

In the early 1960 's many efforts were made by park naturalists and others to identify features that responded to Steamboat Geyser's drastic changes in behavior, as related to major eruptions, in the hope that the following major eruption could be predicted. Echinus Geyser (pl. 1, F5-SE), $200 \mathrm{~m}$ southeast of Steamboat Geyser, may have lengthened its interval after a major eruption of Steamboat, and several features in Porcelain Basin, $450 \mathrm{~m}$ north. northwest of Steamboat Geyser, were suspected of showing some response, but no correlation was definitely confirmed. Cistern Spring (pl. 1, F5-W center), $100 \mathrm{~m}$ southwest of Steamboat Geyser, had existed for many years without obvious response to Steamboat's activity. However, by late spring of 1966 (fig. 8) evidence of Cistern's response to major eruptions had become obvious. Cistern had been an inconspicuous quiet dark-gray spring not recognized or mapped by some early explorers but probably noted by Peale (1883) as early as 1878 as his spring no. 44 and also mapped in 1954 by W.V. Watson (Yellowstone informal manuscript and map, 1954). By June 1966, Cistern was a vigorously boiling opalescentblue spring that had recently started to erode its western rim and was discharging copiously downslope to the south, killing a broad swath of trees and thereby indicating major changes in behavior, but had not yet built up local sinter deposits around its pool.

After Steamboat's major eruption of June 19, 1966, Cistern became turbid, its water level eventually declined $1.5 \mathrm{~m}$, and its surface temperature decreased. During Steamboat's following major eruption on August 10, Cistern surged or even erupted mildly at about the same time, but within 90 minutes after Steamboat's initiation, Cistern's water level was falling, eventually to about $-2 \mathrm{~m}$. During Steamboat's major eruption of June 3, 1968, D.E. White observed that Cistern's water level (fig. 8) had already fallen $5 \mathrm{~cm}$ from its previous overflow level within 20 to 30 minutes after Steamboat first started. Cistërn's minimum level was not observed, but within three days its level had returned to $-0.3 \mathrm{~m}$, and by the fourth day the spring was again boiling vigorously and discharging turbid water.

Steamboat Geyser's major eruptions started to decrease in frequency (see subsection "Steamboat Geyser") at about the same time that Cistern first showed a clear response in 1965. Some close observers suggested that Cistern's increased discharge and vigor were causing Steamboat's change, which seems reasonable, but positive evidence is lacking. However, the two features clearly are interconnected.

Since 1978, Steamboat's major eruptions (table 7) normally result in a draining of Cistern's pool by 5 to $7 \mathrm{~m}$ and a cooling of its surface temperature by about $20^{\circ} \mathrm{C}$. During one of these deep drainings, spectacular sinter "scales" that had formed on logs and pool margins were visible (fig. 44). Since 1965, Cistern has been depositing copious quantities of sinter at rates as high as $5 \mathrm{~cm} / \mathrm{yr}$ from nearly neutral water. The rate of deposition obviously differs greatly from place to place. We suspect that after a major Steamboat eruption and its long violent steam phase, much water underground is greatly supersaturated in $\mathrm{SiO}_{2}$, thereby affecting its rate of $\mathrm{SiO}_{2}$ deposition when soon discharged through Cistern's vent. 
TABLE 7.-Recorded major eruptions of Steamboat Geyser, Norris Geyser Basin, 1878 through June 1984

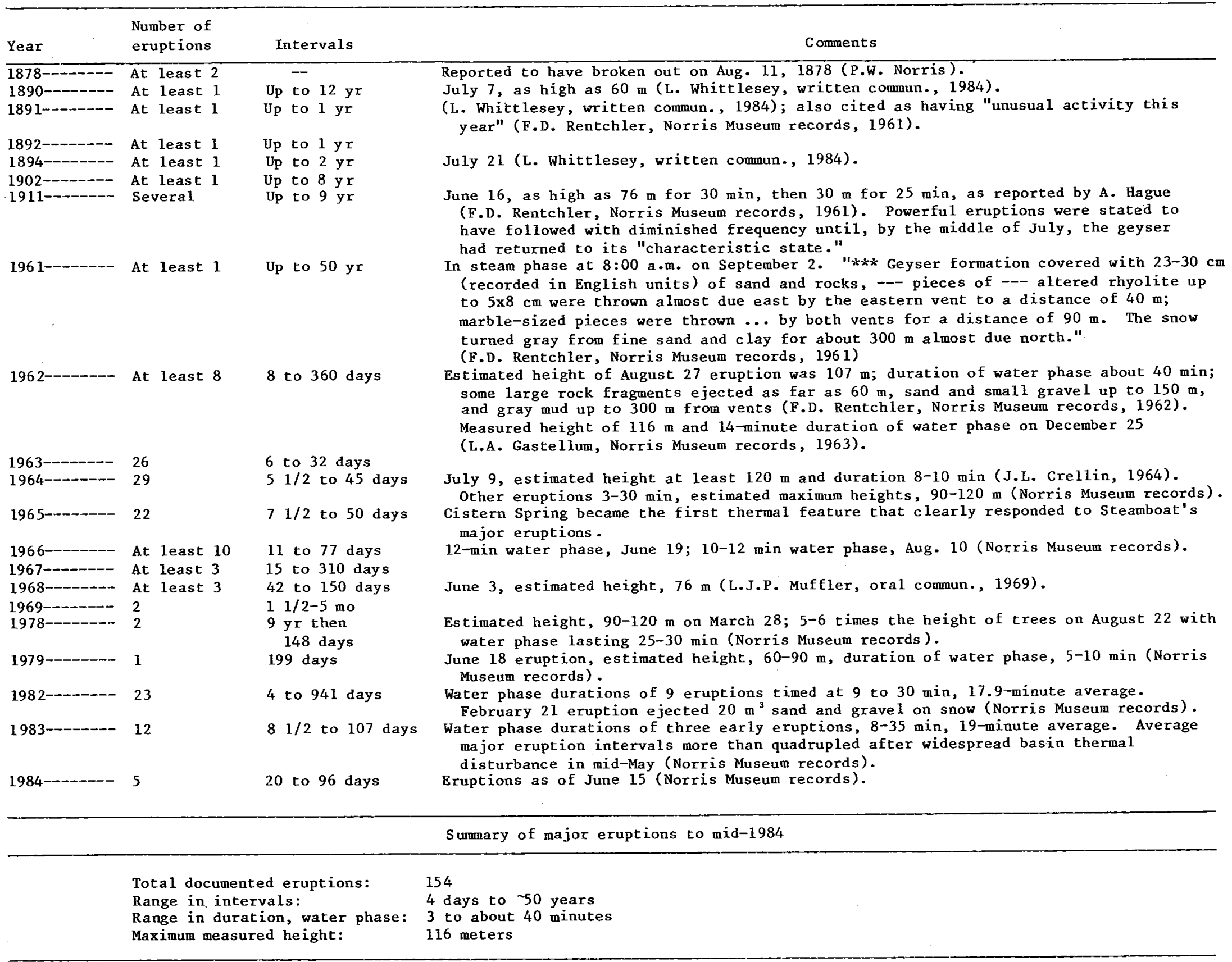




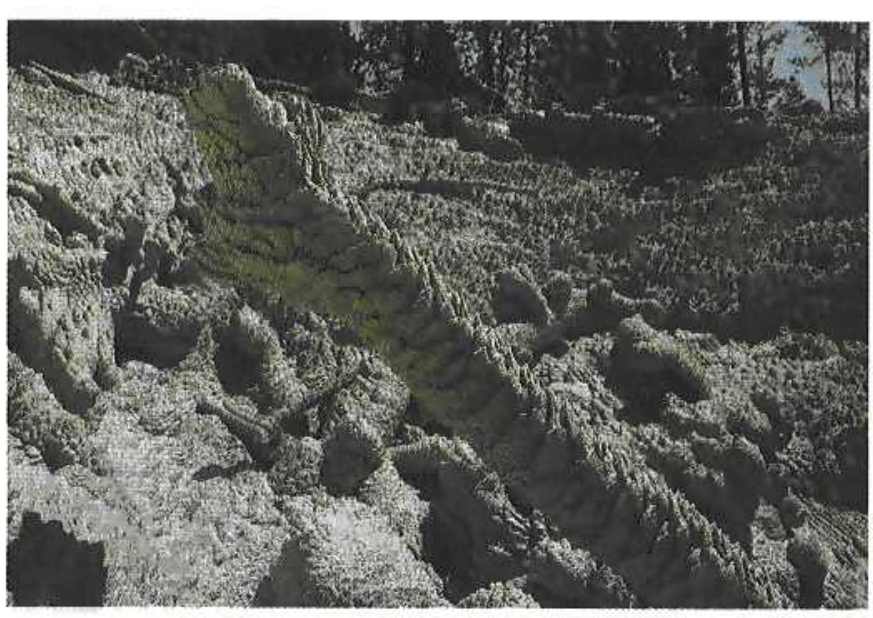

FIGURE 44.-Cistern Spring (pl. 1, F5-W center) drained 5 to $7 \mathrm{~m}$ below overflow in response to a major eruption of Steamboat Geyser. Sinter "scales" had deposited on logs and pool margins during intervening years, pointing in direction of convective flow; foreground tree trunk $\sim 0.3 \mathrm{~m}$ in diameter. Photographed November 1982 .

\section{CONGRESS POOL}

According to Allen and Day (1935, p. 480-481), from old records, Congress Pool (pl. 1, D5-SE) “*** was in 1883 a steam vent, varying greatly in activity at different times. In 1891 the ground about it suddenly caved in, leaving a hole 20 feet across, that gradually enlarged till it reached 40 feet in the widest place, filled with water and occasionally overflowed. In 1891 it was displaying powerful eruptions with periods of rest like a normal geyser. The water, originally turbid, became clear and blue. Later it ceased to erupt and became 'a constantly agitated boiling spring." " Since Allen and Day first saw Congress Pool about 1925 , it has generally been characterized by muddy water varying greatly in level at different times, but no eruptions have been reported.

Allen and Day's (1935) description of Congress Pool since 1925 is a good generalization of irregular observations by D.E. White from 1947 until the present, except that, during two periods, the pool overflowed at rates of as much as $10 \mathrm{~L} / \mathrm{min}$, when the normally turbid water (acid Cl-SO $\mathrm{SO}_{4}$ of type III; Allen and Day, 1935, analysis 87, p. 469) changed to an opalescent blue (figs. 32,33 ). This indicates upward flow of nearly neutral deeper water of type I, high in $\mathrm{Cl}$ and supersaturated in monomolecular $\mathrm{SiO}_{2}$.

\section{ECHINUS GEYSER}

Echinus Geyser (pl.1, F5-SE; figs. 22, 23) is one of the best known thermal features of Norris Basin. It was named by Peale (1883) because of its colorful red, brown, and yellow-brown spinose sinter, reminiscent of the spines of sea urchins (echinoids). Although Echinus has changed its activity many times, it has commonly been one of the more predictable major geysers of Norris Basin. Intervals of eruption generally range from 25 to 45 minutes, and eruption heights are as great as $30 \mathrm{~m}$ for individual spurts. At other times its activity has been more varied and unpredictable, with long intervals of dormancy. From 1878 to 1948 eruptions were rare (W.V. Watson, Yellowstone informal records), but Lee Whittlesey (informal historian) found records of eruptions during 1885, 1887, and 1954. By the summer of 1948 Echinus was one of the more predictable geysers of Norris Basin.

Immediately after an eruption (figs. 22,23 ), the pool commonly drains 1 to $2 \mathrm{~m}$ below its overflow level, then refills, at first slowly and then rapidly to its overflow level. After preliminary discharge as long as 25 minutes in duration, an eruption then occurs. In some years, however, the geyser has erupted during its late filling stage, with no preliminary overflow. Violent eruptions in 1978 and 1979 ejected fragments of banded iron sulfides, collected by R.A. Hutchinson and later identified by T.E.C. Keith as pyrite and marcasite. The banded sulfides can be observed in a few places as veinlets as shallow as $2.5 \mathrm{~m}$ below the crater rim.

Spinose red, yellow, and brown sinter is characteristic of acid waters, consistent with the recorded $\mathrm{pH}$ of 3.35 to 3.6 for Echinus (Rowe and others, 1973; fig. 23). At such a low $\mathrm{pH}$, considerable iron, arsenic, and aluminum are generally also in solution, thus explaining Allen and Day's (1935, p. 484) analysis of sinter from Echinus in which they suspected scorodite, the ferric arsenate described by Hague (1887): in percent, $\mathrm{SiO}_{2}, 20.23 ; \mathrm{Al}_{2} \mathrm{O}_{3}$, 5.83; $\mathrm{Fe}_{2} \mathrm{O}_{3}, 56.87 ; \mathrm{CaO}, 0.47 ; \mathrm{SO}_{3}, 1.40 ; \mathrm{As}_{2} \mathrm{O}_{5}, 4.96$; $\mathrm{H}_{2} \mathrm{O}, 10.70$; total, 100.46. At Echinus, the deeply colored sinter occurs as a thin coating on the tops and sides of large blocks of prehistoric massive white sinter to depths of about $0.4 \mathrm{~m}$ below the overflow level. Some of these blocks have collapsed into the pool. The massive white sinter with colored surfaces is $\sim 1 \mathrm{~m}$ thick and overlies clastic material containing tree stumps and branches, largely unsilicified. A wood sample collected by R.A. Hutchinson in 1977 yielded a ${ }^{14} \mathrm{C}$ age of $530 \pm 60$ years B.P. (S.W. Robinson, USGS Sample No. 1297, written commun., 1982). Thus, drastic changes in activity and water chemistry of this vent are indicated.

On August 28, 1969, Echinus was probed $3.0 \mathrm{~m}$ below the level of deeply colored (most oxidized) sinter, or about $3.4 \mathrm{~m}$ below its overflow level, by Manuel Nathenson and D.E. White of the U.S. Geological Survey. Temperatures measured at $-3.4 \mathrm{~m}$ ranged from 98.0 to $102.5^{\circ} \mathrm{C}$ during the five minutes before an eruption, but were only 90 to $95{ }^{\circ} \mathrm{C}$ when measured during the following eruption, when subboiling temperatures were not expected and 
seemed anomalous. These and other data indicate that two kinds of water of different composition and temperature are involved. Variations in $\mathrm{pH}$ and chloride contents of water samples from Echinus are greater than in most other Yellowstone geysers, and $\mathrm{Cl}$ is relatively low. These data are best explained by the mixing of deep, hot chloride water and a more abundant shallow water lower in temperature, $\mathrm{Cl}$, and $\mathrm{pH}$. The Echinus analysis in table 4 (type IIIa) could be satisfied by about 15 percent of deep $\mathrm{Cl}$ water and 85 percent of dilute acid meteoric water of type IIb.

\section{GREEN DRAGON SPRING}

The origin or origins of near-boiling acid $\mathrm{SO}_{4}-\mathrm{Cl}$ (or $\mathrm{Cl}-\mathrm{SO}_{4}$ ) waters of high discharge but lacking local evidence of abundant surface oxidation of $\mathrm{H}_{2} \mathrm{~S}$ has been long debated. White (1957), using Green Dragon (fig. 24) as his type example in the United States, suggested that acid $\mathrm{Cl}-\mathrm{SO}_{3}$ emanations similar to those of hightemperature low-pressure volcanic fumaroles were responsible. Ellis and Wilson (1961) countered with two other possibilities, the first depending on neutrality of unionized sulfuric acid at high temperatures, rapidly increasing in dissociation to free sulfuric acid with falling temperatures; their second possibility invoked subsurface reaction with previously deposited native sulfur. At that time (1955-61) the temperatures involved $\left(\sim 77^{\circ} \mathrm{C}\right)$ were considered too high for sulfur-oxidizing organisms to live in hot-spring pools, but Brock and others (1972) soon proved that Sulfolobus could exist and oxidize $\mathrm{H}_{2} \mathrm{~S}$ to sulfuric acid at boiling temperatures and low $\mathrm{pH}$. Sulfolobus is now known to be abundant in Norris Basin. Still a fourth possibility assumes that some recharging acid meteoric waters on the southeast margins of the basin owe their acidity to surface oxidation of $\mathrm{H}_{2} \mathrm{~S}$ and $\mathrm{S}$ (see subsection "Acid-Sulfate Waters" and table 4). We now consider the last two methods for acquiring sulfate acidity as most generally applicable for Norris Basin, but primary volcanic acidity must still be considered for copious discharges from acid springs associated with island-arc subduction and volcanism.

\section{HARDING GEYSER}

Harding Geyser (pl. 1, E5-NW, 30 m east of Norris Museum) first erupted in 1923 and was named after President Harding, who visited the park that year (Allen and Day, 1935, p. 479). Shortly afterward, it disappeared from the list of active geysers and was called Harding Steam Vent (W.V. Watson, Yellowstone informal records, 1954). Although Harding is a minor geyser, it still occasionally erupts from the second highest altitude vent $(2,308 \mathrm{~m}$, or $\sim 7,570 \mathrm{ft}$ ) known to have discharged chloride water in
Norris Basin, being exceeded only by Steam Valve Geyser (fig. 35). No record of further activity was noted until August 9, 1966, when Harding erupted again, ejecting muddy water and small rocks to heights of 6 to $9 \mathrm{~m}$ (Lewis, Yellowstone informal records, 1971; table 6). Its water phase lasted 8 to 10 minutes, followed by a "chugging" steam phase that persisted for about 30 minutes. This eruption was followed by others during the same month.

Harding also erupted several times in 1967 with vigorous surging and boiling high in the vent and intermittent splashing discharge and erosion of a channel $60 \mathrm{~m}$ downslope from the vent. Additional eruptions were recorded in 1968, 1974, 1976, 1978, 1980, and 1984 (Yellowstone informal records).

\section{HYDROPHANE SPRINGS}

The group of normally inconspicuous vents known as Hydrophane Springs is near the southern limit of Norris Basin's surface activity (pl. 1, G3-SE). A quiet standing water level was characteristic of several of the deeper vents. Warm to boiling water was generally visible $\sim 2 \mathrm{~m}$ below the ground surface.

The area near the Hydrophane group is notable mainly because of the thick white opaline sinter visible in deep vents and first emphasized by Allen and Day (1935, p. 486), who commented that its maximum exposed thickness was about $8 \mathrm{ft}(\sim 2.5 \mathrm{~m})$ and probably more. Existing vents did not discharge externally, although subsurface circulation was visible in North Hydrophane (table 3); no evidence existed for any recent deposition of sinter. Allen and Day believed that former alkaline springs had deposited thick opaline sinter, but that the springs then evolved to acid waters not discharging or depositing significant sinter.

Drastic changes occurred in the Hydrophane group during the widespread basin disturbance of July 6, 1982 (table 8). High-silica neutral water started to discharge from a linear zone of vents slightly east of and above the northstriking mapped vents noted on plate 1, block G3-E, extending $150 \mathrm{~m}$ toward Porkchop Geyser. Discharge flowed downslope from these new vents into the older mapped vents as $\mathrm{SiO}_{2}$ polymerized to its characteristic opalescent-blue color (fig. 45). By 1984, most pine trees between the Hydrophane zone and Gray Lakes to the east had died, suggesting that hot shallow subsurface flow had heated the trees' shallow root zone to intolerable temperatures.

\section{MINUTE GEYSER}

The name of Minute Geyser (pl. 1, E4-SE) has had a confused history, having been called Minute, Minute Man, 
TABLE 8.-Widespread disturbances, each of which affected two or more thermal features of Norris Geyser Basin nearly contemporaneously disturbances. Colloidal Pool, normally quiet and a beautiful sky blue, was turbid and boil its water level ture $-84^{\circ} \mathrm{C}$ ). Hurricane Vent, a former geyser, was boiling more vigorously than usual and its water level on had dropped about $10 \mathrm{~cm}$. Hurricane Vent, generally superheated, but during this period its teme $60^{\circ} \mathrm{C}$, was boiling $9{ }^{\circ} \mathrm{C}$ (boiling for altitude of $2,285 \mathrm{~m}$ or $7,500 \mathrm{ft}$ ). One small Primrose Pool, normally near color became turbid. and turbid instead of blue. Emerald Spring was boiling more than usual and its clear green color 6 m high from

Steamboat Geyser, which had been erupting 3 to $12 \mathrm{~m}$ high every $2-3$ minutes, was erupting less that eruption patterns its east vent, and only an occasional small jet from its west vent. Other geysers that changed eruption to $94{ }^{\circ} \mathrm{C}$. its east vent, and onded Little Whirligig and Constant. Black Growler had been $95.5^{\circ} \mathrm{C}$ and quite noisy, then changed to 94 included Little Whirligig and Consty 28 and again on September 3. Such changes have been noticed previously, Such fluctuations were noticed on Jull such occasions, the basin returned to normal in three to four days
but not as often as in 1954 . On all sul but not as often as in 1954 . On all such occasions, ex steam

fluctuations seemed to be caused by an extra release of steam from bectere instead of a higher one, which might be expected.

Related to Hebgen Lake earthquake and aftershocks. A11 hot pools in the basin were more agitats, Steamboat and increased activity lasted about ten days in some but much longer in others. Only two geysers, steame after the Echinus, were immediately affected. Discharge was reported to be greatly diminished for a locos).

event (A. Nash, A resume of the earthquake effects at Norris, in Yellowstone informal records).

September 9-10, 1971 Widespread changes occurred in boiling and turbidity in Colloidal, Jetsam, and congress Pools, and in Basin, Africa, Glacial Milk, and Little Whirligig Geysers. By evening all significant hot spre Mouth (p1. 1, D4-E), had Porcelain Basin south and east of a line from Onyx Spring ( $\mathrm{pl}$. 1, D become turbid or muddy. Also, many became more active--either in the bubbling of springs or to have increased by geysers. Total d

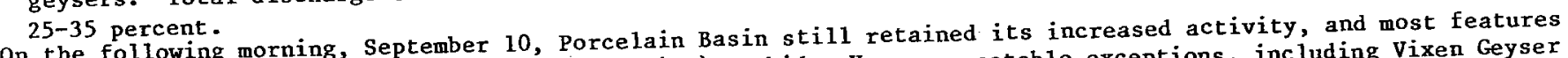
on the following morning, September 10, Porcelain (or) turbid. However, notable exceptions, including Vixen Geyser in the Back Basin had become more active and (or) , became inactive until september 12 when one short eruption (normal interval of 2-4 minutes between eruptions), became if $9 \mathrm{~m}$ compared to its usual 12-25 m of the previous was observed. Echinus Geyser erupted to a maximum heigha. Steamboat Geyser ceased its minor play, with no visible water but still much steam. Prior to June 1971, some thermal energy of Emerald Spring had existed north and northwest borders of pool, creating small "frying pan" springs that drained inied up as boiling shifted making it somewhat turbid. back to Emerald Spring.
The next major change occurred on September 10 before 4:00 p.m., when a new thermal feature broke out in the Back The next major change occurred on september
Basin (pl. 1, G4-NW). In a few hours it grew from $0.6 \mathrm{~m}$ in diameter and $1 \mathrm{~m}$ in depth to $2.4 \mathrm{~m}$ in diameter and
. maximum depth $>2.5 \mathrm{~m}$. In the following months it evolved from muddy pool to mud pot, muddy caldron, The last quiet cool turbid spring and eventually to a boiling opalescent blue spring that deposited sinter. observed major change of the 1971 disturbance occurred during the night of September 10-11. A large graben-shaped hydrothermal explosion trench formed near the base of and parallel to the north-south $1-1.8$ m deep. At the grabelain Terrace (p1. 1, D5-NE; fig. 6). The trench was $9 \mathrm{~m}$ long, $0.9-2.1 \mathrm{~m}$ wide, and $1-1.8 \mathrm{~m}$ deep. south end of the trench a fan of debris washed out over part of the southeast corner 
August 8, 1972

August 18,1973

August 14, 1974 August 20, 1975

August 31, 1976

August 19,1977

September 9, 1978

September 19, 1979
By September 14 the Norris activity started to decrease, first in Porcelain Basin and then in Back Basin. By September 15 discharge had decreased to below normal, especially noticeable in the Porcelain Basin area, with Pinwheel Geyser as an excellent example. No water flowed into it, the drainage outlet was dry, and the water level in the pool was down more than $20 \mathrm{~cm}$ below its usual level. Within the next four days water levels in the
Back Basin started to follow suit and dropped below normal as some features began to fluctuate erratically. The below-normal discharge may have been recovering from the as some features began to fluctuate erratically. The thereby recovering its former aquifer pressures. A large opalescent blue discharges of September 9 and 10 , Porcela recovering its former aquifer pressures. A large opalescent blue silica-rich pool at the base of Porcelain Terrace (p1. 1, D5-SE) ceased flowing. Shallow ground water drained from the pool as its thin 8-cm platy sinter floor collapsed.

22 had the disturbance, 30 features had increased temperatures of $0.5{ }^{\circ} \mathrm{C}$ to $28{ }^{\circ} \mathrm{C}$ (average gain, $6{ }^{\circ} \mathrm{C}$ ); as discharge and

and Africa Geysers erupted and Little Whirligig, Arsenic, Pool frica Geysers erupted almost continuously. New, short-lived mud pots appeared on south rim of Congress Spring (pl. 32) and a new long-term vent $2.5 \mathrm{~m}$ in diameter and $1.5 \mathrm{~m}$ deep formed near the original Muddy Sneaker Spring (pl. 1 ,

isturbance first observed at 9:45 a.m. at Colloida1 Pool (p1. 1, D5-S center). All features in Porcelain Basin were very muddy and numerous springs in Back Basin were bubbling violently; behavioral changes in major geysers included Echinus (mid-eruption pauses), Pinto Geyser (active), Ledge Geyser (extended steam phase), Vixen Geyser (weak minor eruptions), Africa Geyser (continuous roaring steam phase, audible in campground $2 \mathrm{~km}$ away). A third vent emerged in the Muddy Sneaker Complex on August 20. Discharge decrease, to below normal began on the 21 st.

Effects of disturbance included increased turbidity, water and gas discharge, but details not recorded.

First observed in Porcelain Basin in afternoon. Increased turbidity, fluctuations in water level, changes in temperature, and geyser behavior, as in prior years. Monarch Geyser Crater especially turbid (as after the June 30 earthquake, magnitude 6.1 , centered near Norris, which had few other effects). Echinus Geyser's intervals decreased from 80 to 75 minutes. Discharge of Cistern Spring decreased, many terraces dried up;

Tangled Root Complex flowed from new vents. Water levels and discharges then decreased, beginning Aug. $24,1975$.

Disturbance first noted in Emerald Spring and Echinus Geyser; most vents in Porcelain Basin became turbid; Congress Pool's water level abruptly rose $60 \mathrm{~cm}$, with very vigorous boiling. Tantalus Creek discharge and turbidity increased from Back Basin. Water levels and discharges began declining on September 3 . Prior to the disturbance, a part of Porcelain Basin's sinter floor had been visibly oscillating about $2 \mathrm{~cm}$. During the initial disturbance, a new Porcelain Springs vent broke out at the south base of the Terrace, terminating the pulsations.

Discharge from Porcelain Basin increased and became turbid; Congress was again turbid instead of blue. Most of the Glacial Melt Complex became more turbid and gassy, and similar changes were reported in the Back Basin. The whole Porcelain Basin became more visibly active, including water spouts and boiling. Decline in activity and tevels started on August 21.

Many features in Porcelain and Back Basins became turbid overnight; increased surging and boiling noted in Colloidal Pool, Constant Geyser, Blue Geyser, Fireball Geyser, and Hydrophane Springs. The north part of Black Pit Spring changed September 14-15 from a quiet shallow spring to a vigorous thick mud pot.

Terraced pools of Cistern Spring's discharge apron drained; at least 145 vents in Porcelain Basin were erupting and spouting from 0.2 to $3 \mathrm{~m} \mathrm{high;} \mathrm{many} \mathrm{vents} \mathrm{not} \mathrm{previously} \mathrm{active} \mathrm{became} \mathrm{new} \mathrm{geysers} \mathrm{(Fred} \mathrm{Hirschman,} \mathrm{seasonal}$ naturalist, oral commun., 1980) or increased in turbidity, and most other geysers changed their eruption patterns; Steamboat's minor splashing ceased. Discharge from Porcelain Basin became dark gray west of Africa Geyser from turbid water, and the odor of hydrogen sulfide seemed stronger. 
TABLE 8. -Widespread disturbances, each of which affected two or more thermal features of Norris Geyser Basin nearly contemporaneously-Continued Basin included Opal Springs, other parts of Porcelain Terrace, Onyx and Primrose sprivity and turbidity. In the Arsenic, Fireball, Whirligig, and Dark Cavern Geysers, generally with increased higher eruptions and external. Back Basin, Echinus and Vixen Geysers changed their behavior, with Vixen having highe of the Hydrophane Springs discharge, but by the next day, Vixen was weak and its adjacent pool had dried. One of the thdrophane spe discharge, but by the next day, Vixen was weak and meters south of Hydrophane Springs many lodgepole pines were dying from increased temperatures.

August 2, 1981

tom Blue Geyser; Emerald Spring became turbid Disturbance was first evident at 9:40 a.m. by dark gray discharge from Blue Geyser, Emor eruptions. Activity, as boiling increased. Echinus Geyser's normal activity changed with additional minor eruptions. Active normal on or turbidity, and gas discharge increased in most features during August 2-4; many then returned to became active after August 7. However, a short-Iived cone-type geyser (called Graceful Geyser, pl. 1, C6-SW) became active August 21 at the north end of Porcelain Terrace, attaining eruption heights near $15 \mathrm{~m}$, but later ceased after August 21 atike vent self-destructed.

June 30,1982

the nozzlelike vent self-destructed. A minor Back Basin disturbance reported; activity declined

its annex; and eruptions from Echinus Geyser decreased.

July 6, 1982

isturbance initiated between $12: 30$ and $1: 45 \mathrm{~m} . \mathrm{d}$.t.; first noted by greatly inost other features. Echinus Geyser in Emerald Spring, followed by increased turbidity and fluid discharges in most other feaced its minor play and changed to shorter intervals and more minor eruptions; Steamboat Geyser drastically redity. Graceful Geyser external discharge; pools in its runoff channel were milky, suggesting precursor turbidity. Graced channel; major again became active and one spring on Porcelain Terrace developed a black sulfide-stained rusonal change. changes were later observed in the Hydrophane group, not previously known to respond to seasonal change. Earliest disturbance ever recorded, perhaps as early as May 13, with changes in Steamboat and Harding Geysers. Major effects obvious on May 19 with rejuvenation of several geysers, increased turbidity, and gassiness springs, especially along two parallel trends, one extending from the north end of porcelain lextending southwest Steamboat Geyser to the Echinus-Crater Springs area and the second, confined to Back Basin, extending south

to Hydrophane Springs.
The most spectacular change was rifting, initially $48 \mathrm{~m}$ long, north-northwest along the crest of porcelain Terrace. During 1982 this zone had increased in heat flow and instability of steaming ground, extensive Terrace. During 1982 this zone had increased dying vegetation, and high discharge of silica-rich waters from Growler Spring and unnamed springs to slumping, dying vegetation, and horth. In the 1983 disturbance, numerous powerful steam vents emerged along the rift as silica-rich springs the north. In the 1983 disturbance, numerous powerful steame in addition, many muddy spouters formed, with ejecta rims or ceased flowing except at the rift's northern end. In addition, many muan massive yellow sulfur from subsur cavity deposits.

The disturbance continued for several weeks, but by mid-summer most features had returned to their previous 9 during patterns. However, long-term changes included decreased major eruptions from Steamboat Geyser (froed from a small the first 4-1/4 months of 1983 to only 3 during the next 10-1/4 months). Black Pit Spring changed "frying-pan" spring to a vigorous fumarole, ejecting steam, muddy water, and rock debris to $\sim 7$ m. Crater Spring, not
as $10 \mathrm{~m}$.

as $10 \mathrm{~m}$. 
and Mi-nute. According to Marler (1964), the name Minute is correct, originally referring to A.C. Peale's early observations on the frequency of its (minor) eruptions.

Minute has had two vents, each with different magnitudes of eruption when both were active (fig. 46). The small southeastern vent is still active, generally erupting 0.3 to $5 \mathrm{~m}$ high, but the large northwestern vent formerly supplied rare major eruptions at varying intervals, stated to range from 6 to $25 \mathrm{~m}$ in height. In September 1926, the geyser erupted continuously for three days to a height of 12 to $15 \mathrm{~m}$ (Allen and Day, 1935, p. 184).

Prior to 1967, Minute Geyser was only 20 m east of the then-existing main road through Norris Basin, connecting Mammoth and the Firehole Geyser Basins. Minute had been subjected to intense vandalism until the road was relocated early in 1968 (pl. 1). A Norris naturalist observed in 1935 (Yellowstone informal records) that "One evening I found about 10 boulders ranging up to the size of a man's head, almost completely filling the smaller of two openings. I was able to remove all except one which had lodged in a turn of the tube."

Both vents were unobstructed in 1947 when D.E. White first observed Minute in superb eruption (fig. 46). At its peak, jets from the northwest vent were 15 to $20 \mathrm{~m}$ high, whereas the smaller southeast vent emitted mostly steam with water droplets. This major eruption seems to have been the last recorded, but minor eruptions from the smaller vent continue to occur frequently, probably ex-

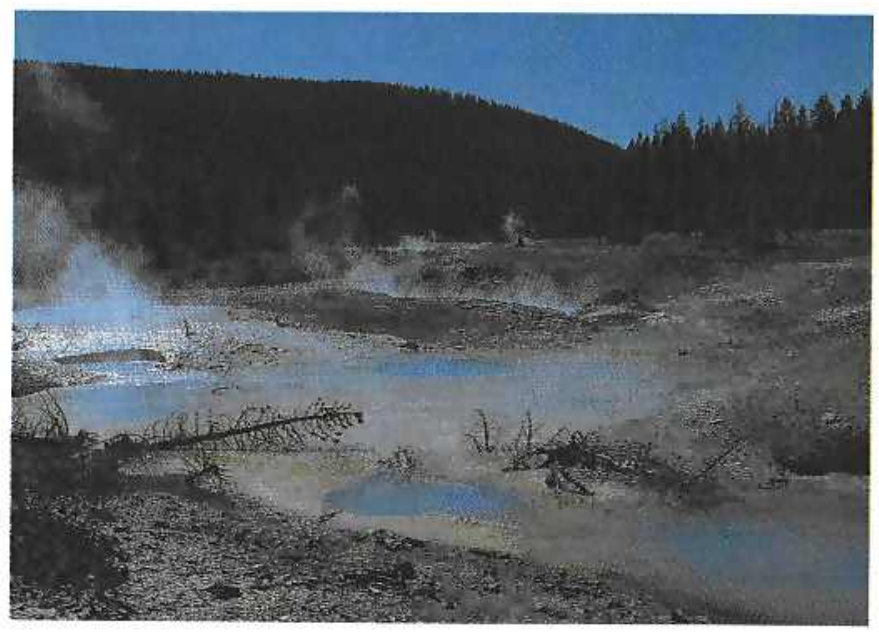

FIGURE 45.-Hydrophane Springs (pl. 1, G3-E) from the north. Water rises in a broad pool (least opalescent blue) behind steam plume on left, flows into adjacent pools as water cools and $\mathrm{SiO}_{2}$ polymerizes to opalescent $\mathrm{SiO}_{2}$, then disappears underground in old Hydrophane vents in middle distance. Some shallow spring borders are colored $\tan$ and brown by algae that cannot tolerate high spring-water temperatures. Round pool in foreground is about $1 \mathrm{~m}$ in diameter. Photographed September 17, 1984. plaining the confusion over the geyser's correct name. Close inspection of the west vent in 1969 revealed that vandals had long been active. The vent was full of rocks, some of which were deep in its throat, firmly cemented in place by sinter; only a crowbar, great effort, and partial destruction could have cleared the obstructions.

\section{MONARGH GEYSER CRATER}

Monarch Geyser Crater (pl. 1, F4-NE) is a large pool in an alcove cut into Lava Creek Tuff. Except for Steam-

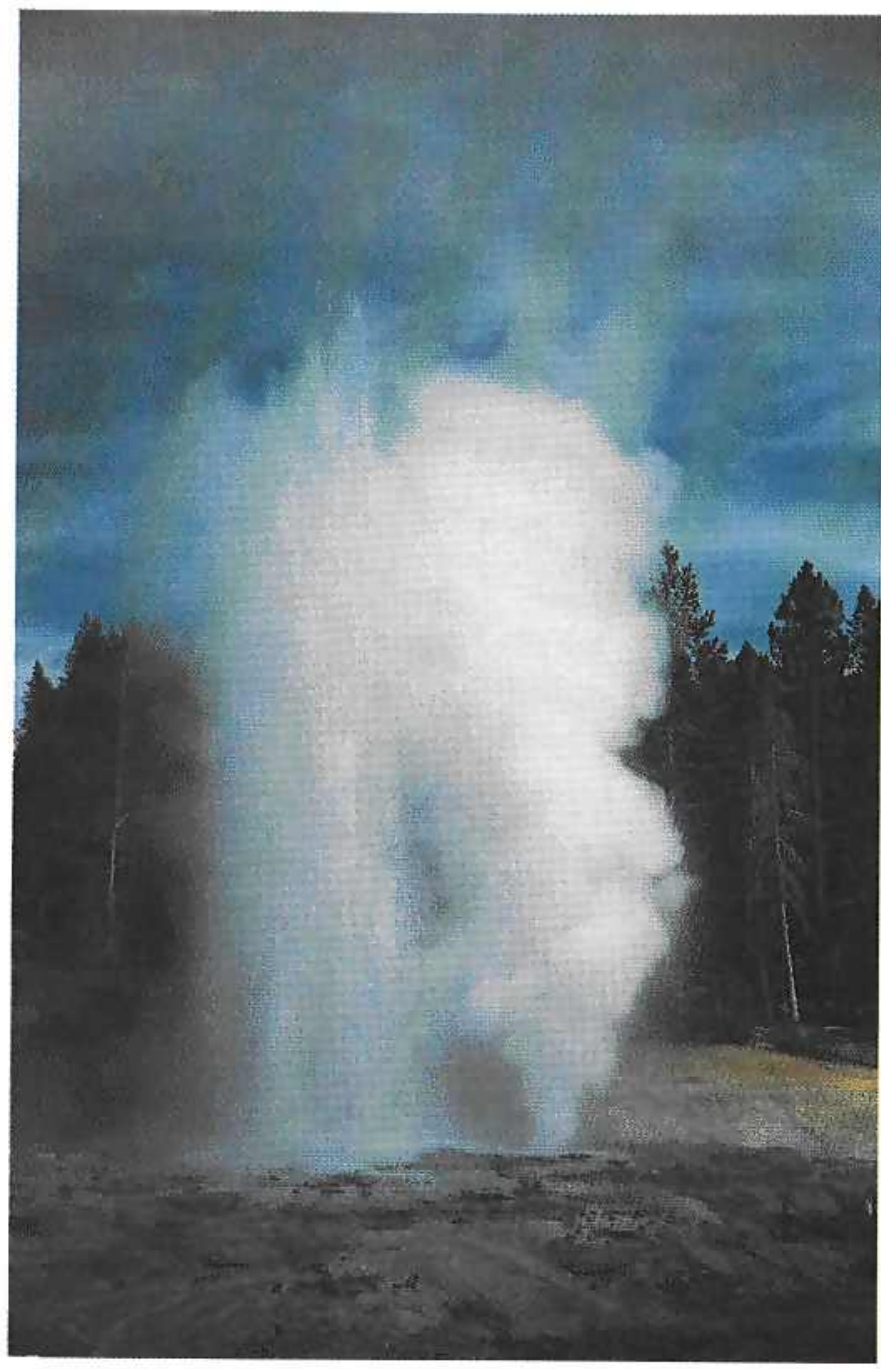

FIGURE 46.-Minute Geyser (pl. 1, E4-S center) in major eruption about $20 \mathrm{~m}$ high. Geyser was later vandalized by filling its large western vent (left) with rocks that became firmly cemented by sinter. Small eastern vent, here steaming vigorously, continues to have minor eruptions several meters high. Photographed September 1947, looking northeast. 
boat Geyser, Monarch has been the most powerful geyser recorded in Norris Basin. Until about 1900, Monarch was periodically active, with intervals of eruption ranging from hours to days. During some eruptions, a massive column of water would rocket to a height estimated at 25 to $40 \mathrm{~m}$, with one observer claiming $60 \mathrm{~m}$. According to P.W. Norris, Yellowstone's second Superintendant, his first observed eruption (1881) was accompanied by vigorous rumbling that shook the basin. Discharge of water was so great that it stopped all travel on the old ungraded road through the basin.

Allen and Day (1935, p. 476-477) stated that Monarch ceased to play in 1911 , but a search of records by Lee Whittlesey, former historian-concessionaire (written commun., 1984), suggests that Monarch actually ceased in 1913. A photograph published by Allen and Day (1935, fig. 201) shows violent jets that are black and gray rather than white, indicating the presence of abundant mud and rock fragments. This coloration is characteristic of very violent geysers that are destroying their subsurface channels, tending to "commit suicide." In recent years Monarch's vent has discharged acid $\mathrm{SO}_{4}$-Cl water at a nearly constant rate.

\section{PHILLIPS CAULDRON}

Small mud pots or mud volcanoes are occasionally seen in Norris Basin (as in fig. 32), but large ones are rare. The largest we have seen is Phillips Cauldron (fig. 47), which is also unusual because of its persistence.

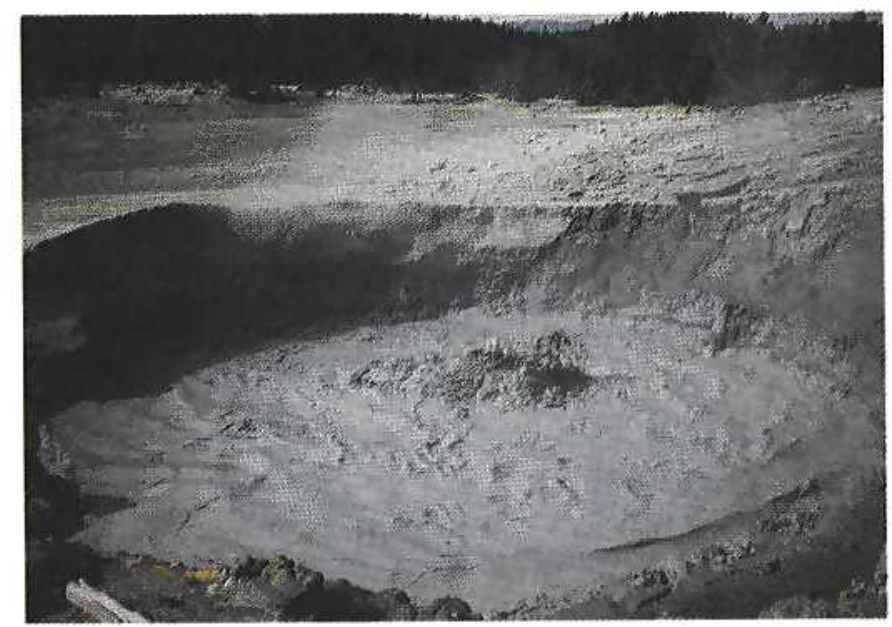

FIGURE 47.-Phillips Cauldron (pl. 1, G4-W center), a mud volcano that was vigorously active in 1947 , intermittently ejecting thick mud clots when surface water was scarce, but a surging gray viscous pool when surface water was more abundant, as shown here, September 1947, when pool was about $4 \mathrm{~m}$ in diameter.

\section{PORCELAIN TERRACE AND PORCELAIN SPRINGS}

Porcelain Terrace (pl. 1, D6-NW, C6-SE) probably undergoes more frequent natural changes than any other part of Norris Basin and Yellowstone Park (figs. 6, 7, 31, 48). Most but not all of these changes have occurred near the south end and base of the terrace. Allen and Day $(1935$, p. 152-155) recorded very high rates of sinter deposition in 1926 near Opal Spring, where as much as $32 \mathrm{~mm}$ was deposited in about 11 months as compared to a maximum of $3 \mathrm{~mm} / \mathrm{yr}$ observed by these authors in other Yellowstone areas. Even faster deposition was observed by R.A. Hutchinson in 1972 at the south base of the terrace (pl. 1, D5-E border, near where fig. 6 was taken), 9 to $10 \mathrm{~cm}$ of sinter being deposited in 12 months from opalescent water exceptionally high in $\mathrm{SiO}_{2}$ (Hutchinson, 1972, Yellowstone informal records, p. 28). The highest depositional rates, according to Allen and Day (1935), occurred in springs of neutral or alkaline $\mathrm{pH}$ and highest in contents of $\mathrm{SiO}_{2}$ (as much as $717 \mathrm{ppm}$, or more than double the average $\mathrm{SiO}_{2}$ content of Upper Geyser Basin waters). We agree with this conclusion.

When D.E. White first observed Norris Basin in late September 1947, the southern crest of the terrace south and southeast of Opal Spring had many miniature geysers and perpetual spouters that discharged mixtures of steam and droplets of water. Several small geysers had "pincushion" cones (similar to those shown in figs. 7 and 29) that intermittently erupted water and steam from numerous tiny self-sealing vents. Some individual channels had recently filled completely with sinter and ceased to flow.

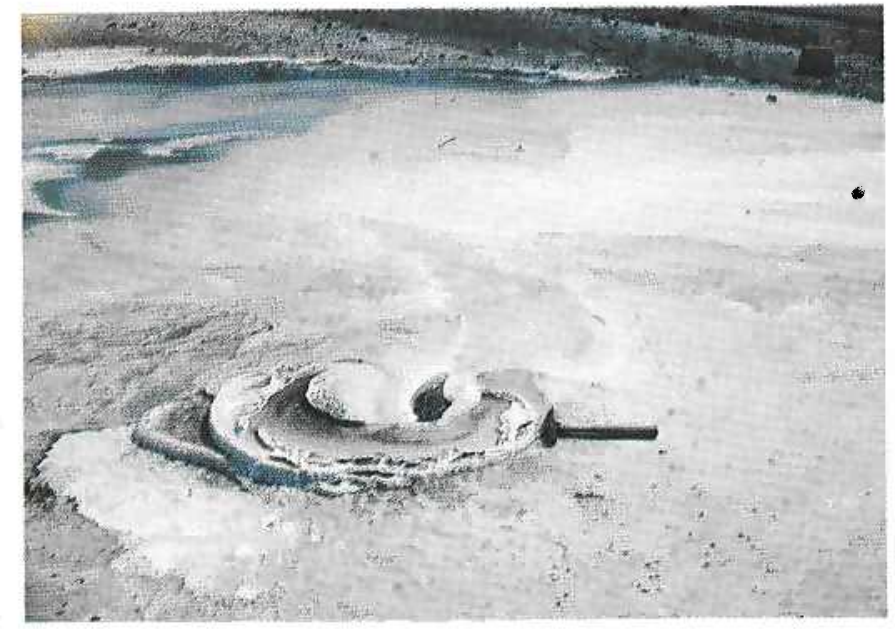

FIGURE 48.-Ornate terraced sinter vent of a short-lived spring at south end of Porcelain Terrace (pl. 1, D6-NW). Note natural levees of white opaline sinter that confine most discharge to a single channel away from vent. Colors are darker where water is deeper. Photographed September 25, 1967. 
At the time of a later visit in August 1954, most discharge from the terrace was from a single new vent, estimated at about $75 \mathrm{~L} / \mathrm{min}$ of slightly superheated water $\left(94^{\circ} \mathrm{C}\right)$. By the following year (July 1955), discharge from this vent had decreased to about $20 \mathrm{~L} / \mathrm{min}$. Silica content was so high that colloidal silica had already formed in the water prior to discharge (White and others, 1956, p. 29), indicated by a slight opalescence from scattering of light. Sinter was depositing rapidly on the channel margins, forming so-called natural levees as much as $1 \mathrm{~cm}$ above the central channel and surrounding levels.

The Hebgen Lake earthquake of 1959 temporarily resulted in cessation of discharge of water from springs on the crest of Porcelain Terrace, with only a feeble discharge of gases. The water level in Opal Spring (fig. 29 ), the largest and only individually named feature on the southern end of the terrace, was $0.6 \mathrm{~m}$ below its sill level, and its temperature had declined from boiling to $58^{\circ} \mathrm{C}$. Its water, formerly nearly neutral and highest in $\mathrm{Cl}$ and $\mathrm{SiO}_{2}$ of all Norris springs, had changed drastically to the acid-sulfate type, low in $\mathrm{Cl}$.

The crest of Porcelain Terrace again discharged actively in 1965, and a new geyser or perpetual spouter on the south bank of Opal's vent had nearly vertical walls to $-1 \mathrm{~m}$ and was discharging into the half-filled vent, then draining downward through cracks in the vent walls and bottom. The widespread changes of September 9-10, 1971 (table 8), included a large new trench blasted from the base of Porcelain Terrace (fig. 6) about $85 \mathrm{~m}$ southsouthwest of and downslope from Opal Spring. The trench dimensions were about $10 \mathrm{~m}$ north-south, 1 to $2 \mathrm{~m}$ eastwest, and $<1$ to $2 \mathrm{~m}$ deep. At the south end of the trench a fan of sinter debris and underlying acid-leached Lava Creek Tuff had swept over the adjacent floor of Porcelain Basin. This was evidently a miniature hydrothermal explosion, similar to but much smaller than the huge historical explosions recognized elsewhere in Yellowstone Park (Muffler and others, 1971), probably including the 100-m-diameter craterlike feature of western Norris Basin (pl. 1, D2-NW; foreground of fig. 5).

The new 1971 vents at the base of Porcelain Terrace, herein called Porcelain Springs, were accompanied by draining of most springs on the crest of the terrace, where discharge of less than $0.4 \mathrm{~L} / \mathrm{min}$ continued. In contrast, the new vents at the base were discharging at an estimated rate of 150 to $200 \mathrm{~L} / \mathrm{min}$, and physical evidence indicated that discharge rates had been much higher. The discharging vents of the 1971 explosion sealed themselves by late 1980 as new ones developed at the terrace base to the west and southwest.

The walls of new vents and most other vents on the west slope of the terrace show that, even in this area of relatively rapid deposition, sinter is seldom thicker than $1 \mathrm{~m}$, overlying strongly leached Lava Creek Tuff.

\section{PORKCHOP GEYSER (SPRING)}

A small unnamed spring in the Back Basin (pl. 1, F4-SW) intrigued Allen and Day (1935, p. 482) and, a few years later, White and others $(1956$, p. 34) because of its exceptionally high contents of $\mathrm{Cl}$ and $\mathrm{SiO}_{2}$, even for Norris Basin (figs. 11, 12, 13). This spring remained unnamed until 1961, when it was informally called Dr. Morey's Porkchop, now shortened by National Park Service policy to Porkchop. This spring was convenient for D.E. White to observe over the years because of its accessibility near the old Norris Road prior to the 1967 bypass construction (see pl. 1). Porkchop normally had a slightly surging nonopalescent discharge; rarely, a geyser eruption 3 to $5 \mathrm{~m}$ high emptied its pool, and it even erupted continuously as a perpetual spouter 3 to $5 \mathrm{~m}$ high in June 1985 (R.A. Hutchinson, written commun., 1985). Also, at even rarer intervals discharge ceased, the water first became opalescent from colloidal $\mathrm{SiO}_{2}$, and temperatures then decreased enough for algae to grow in the pool.

The feathery sinter-coated pine needles, cones, and grass stems (figs. 11, 12) in and around Porkchop interested Allen and Day (1935, p. 482) and other observers who had noted their beauty, variety of colors, and textures of precipitated $\mathrm{SiO}_{2}$, both above and below the normal overflow level. Residence time in the pool is generally so short that all silica remains monomeric, but the opalescent-blue color from light-scattering by colloidal particles has been observed on several occasions. During recent years Porkchop has erupted more frequently as a geyser and even erupted as a perpetual spouter from an empty crater from late March through June 1985 (table 5) and to at least mid-1987.

\section{REALGAR SPRINGS}

Realgar Springs are inconspicuous and were not precisely located on Hague's (1904) map of Norris Geyser Basin, but his mapped "Realgar Spring" is clearly one of the group shown on plate 1, block B4-NW. Nearly all vents of low temperature and seeping discharge in this area have deposited red and orange material first identified as the arsenic sulfides orpiment and realgar (Weed and Pirsson, 1891). Allen and Day (1935, p. 138-140) later confirmed their composition as arsenic sulfide in proportions close to that of orpiment $\left(\mathrm{As}_{2} \mathrm{~S}_{3}\right)$, but no analysis was close to realgar (AsS). These authors also noted that their material was X-ray amorphous. In fact, however, the colors are gradational, with red precipitated material being thicker than yellow. D.E. White also found both red and yellow varieties to be X-ray amorphous (excluding minor peaks identified as clastic $\mathrm{SiO}_{2}$ minerals, quartz, 
tridymite, and $\alpha$-cristobalite derived from ash-flow tuffs). Fine grinding of the massive red variety (color like realgar) yields a yellow color similar to that of thin layers formerly called orpiment. The amorphous $\mathrm{As}_{2} \mathrm{~S}_{3}$ of Yellowstone Park has not yet been described as a new mineral, but metastibnite is the accepted name for amorphous $\mathrm{Sb}_{2} \mathrm{~S}_{3}$, suggesting that metaorpiment may be appropriate for the Norris mineral.

Springs that deposit amorphous arsenic sulfide (close to $\mathrm{As}_{2} \mathrm{~S}_{3}$ ) are characterized by seeping low-temperature discharge, moderately acid $\mathrm{pH}\left(\sim 3^{1 / 2}\right)$, and association with elemental sulfur. The red to orange color is generally visible at the surface, but thicker deposits are commonly a few centimeters below the surface.

\section{STEAMBOAT GEYSER}

Yellowstone's most spectacular geyser was called New Crater Geyser by Norris (1880), but independently Peale (1883) called it Steamboat Vent, now officially Steamboat Geyser.

Steamboat is a cone-type geyser that erupts violently and continuously during a major eruption (frontispieces). Two adjacent vents penetrate deep into bedrock of the Lava Creek Tuff. Each vent is now mantled irregularly by geyserite sinter that ranges in thickness from films to several centimeters, evidently deposited during its frequent minor eruptions (fig. 16). The most complete historical record of Steamboat's activities has been compiled by R.A. Hutchinson (see table 7).

Both Peale (1883) and Norris (1880) agreed that this geyser (or, at least, its major eruptions of 1878) was of recent development; this is strongly supported by Peale's (1883, p. 128) description: "It consisted of two roaring steam-holes on the side of the hill, that look as though they had just burst through the surface, and the gully leading towards the ravine to the south is covered with sand that appears to have been poured out during an eruption. Trees standing in the line of this sand-flood are dead, and a number uprooted and covered with sand, and some of the trees back of the vents have had their foliage killed, but***not yet fallen***. There is no (sinter) deposit marking the opening, although stones surrounding the hole are beginning to have points of geyserite deposited on their upper surfaces."

Norris (1880) stated: "The new crater which burst forth in the Norris Geyser Plateau, with such upturning and hurling of rocks and trees, August 11, 1878, and was for the remainder of last year [1878] a high crater of hissing gas, steam, and mud, seems this year to have settled down to business as a very powerful flowing geyser, having, in common with many others, a double period of eruption, one some 30 feet high about each half hour, and another of nearly 100 feet and long continued, each six or seven days, and is doubtless still changing."

Major eruptions were recorded in 1878, 1890, 1891, $1892,1894,1902$, and 1911 (table 7), but none was measured to heights greater than $30 \mathrm{~m}$. A photograph of a 1911 eruption indicates a massive column that may have exceeded $30 \mathrm{~m}$ in height. Minor eruptions from 5 to 15 $m$ were generally frequent and characterized this geyser for many years. Even the major Hebgen Lake earthquake, centered about $45 \mathrm{~km}$ west-northwest of Norris Basin (fig. 1), had no immediate effect on the geyser. Perhaps as a delayed response, however, the first recorded major eruption in 50 years occurred near midnight on September 2 , 1961. The geyser was not observed until the following morning, but the results were awesome! Altered rock debris covered much of the area, and extensive erosion by falling water and debris occurred as much as $100 \mathrm{~m}$ from the vent, especially upslope to the northeast. Water and debris ran down the slope to the south in three channels, with the largest nearly $4 \mathrm{~m}$ wide and $0.15 \mathrm{~m}$ deep (evidently measured from high water marks).

The next major eruption occurred nearly one year later at 1:25 p.m. on August 27, 1962. Its eruption height was about $110 \mathrm{~m}$; its water phase lasted for 40 minutes, and rocks as large as $10 \mathrm{~cm}$ in diameter were ejected from the southeastern of the two vents. The eruption was very noisy, being heard $\sim 1 \frac{1}{2} \mathrm{~km}$ away. It was still noisy the following morning but subsided that day. A vigorous steam cloud hundreds of meters high was reported to have persisted for three days.

The first careful measurements of eruption magnitude were made by Associate Superintendent Lewis A. Gastellum and his wife on December 25, 1962 (Yellowstone informal records). The eruption started at 2:10 p.m., the eighth of the modern series (table 7). Ejected water was first milky white, but within 2 or 3 minutes it began to turn brown. A series of photographs were later used to calibrate distances. The steam column rose to $400 \mathrm{~m}$, with spurts of water as high as $116 \mathrm{~m}$. Abundant water and debris were ejected for 14 minutes, and steam then became dominant, with ejection of rocks continuing. Fragments weighed as much as $1 \frac{1 / 2}{\mathrm{~kg}}$, and smaller fragments and sand were sprayed more than $300 \mathrm{~m}$ away from the double vent.

Eruptions were closely monitored during the tourist seasons. Some eruptions were observed, either closeup or from a distance, but many others were recognized from new wash and debris, especially during the winter months (table 7), when debris was interbedded with snow at considerable distances from the vents.

At least some undetected winter eruptions no doubt occurred. The minimum recorded interval between major 
eruptions was five days. Nearly a year elapsed between the identified eruptions of September 2, 1961, and August 27, 1962, and also from June 16, 1967, to April 22, 1968. After the second eruption of 1969 (March, day unknown), the geyser ceased its major eruptions for nine years.

These major eruptions (see frontispieces) were interspersed with frequent minor eruptions from 3 to $15 \mathrm{~m}$ high (fig. 16). The geyser generated tremendous interest among tourists, the U.S. National Park Service, and U.S. Geological Survey personnel. Many individuals spent countless hours waiting for the start of another major eruption. The record for perseverance clearly belonged to Mrs. Hazel Decker (now deceased) of Two Harbors, Minnesota. Even though in her late sixties and early seventies, she spent many summer months waiting and watching for more than 130 days during the years that Steamboat was having major eruptions. She once kept vigilant watch on the geyser for 52 consecutive days-a record of interest, devotion, and patience that is unlikely to be surpassed. If a major eruption seemed close, she spent the night sleeping in her car in the parking lot, hoping to be at the site as soon after initiation (evident from greatly increased noise) as possible.

From 1970 to March 1978, Steamboat was characterized by subsurface surging, puffs of steam and occasional spurts of water to the surface, but no water was discharged beyond the vent area. The geyser seemed permanently inactive, but it eventually became more vigorous, first resuming minor eruptions 5 to $10 \mathrm{~m}$ high, and then still higher, but with little or no external discharge. With each widespread thermal disturbance (table 8), Steamboat lost most if not all of its discharging water and was nearly quiet for one to three weeks.

Finally, on March 28, 1978, another major eruption occurred; a second followed on August 22, and a third on June 18, 1979 (table 7). Then more than two years passed, to April 1982, before a second major series similar in some ways to the series of 1960-69 was initiated.

Manuel Nathenson and D.E. White obtained a series of temperature measurements in both vents on June 18, 1974 (fig. 49). The northwest vent was first probed (all depths refer to sill level of southeast vent, which is the lowest local overflow point of this system). The vigorously surging water level in the northwest vent was about $-3.4 \mathrm{~m}$. Temperatures increased downward to $-8.5 \mathrm{~m}$, which was the maximum accessible vertical depth in this channel. Fluctuations in temperature occurred at each depth; the total observed range is indicated by ticks on the horizontal bars, but the duration of observations at each depth was not constant and was not recorded. Vigor of the intermittent minor eruption was clearly less than during the 1960's series and also less than most minor eruptions of the 1980's.
In the southeast vent, measurements started at $-18.3 \mathrm{~m}$ and progressed downward to the accessible bottom at $-25.9 \mathrm{~m}$ (the greatest depth we have attained in a natural Yellowstone vent); measurements then progressed upward at shorter depth intervals through the temperature maximum previously found. Unfortunately, the probe became lodged at the $-6.1 \mathrm{~m}$ level and was eventually lost, perhaps being diverted by a strong surge into the interconnected northwest vent. At most levels, temperatures fluctuated rapidly through as much as $7{ }^{\circ} \mathrm{C}$ during the estimated 3 to 5 minutes that the probe was held at each constant level. These fluctuations were real and not instrumental. Although the time response of the thermistor probe was relatively rapid (a few seconds), the real fluctuations were undoubtedly considerably greater than the probe could record. The near-surface measurements were made in a pulsating, surging two-phase watersteam mixture. The wide variations in temperature at depth are also best explained by two-phase upward surges of water and vapor, with vapor existing at depths much below those predicted by the reference curve constructed for liquid $\mathrm{H}_{2} \mathrm{O}$ just at boiling for pressures of single-phase water (fig. 49). This reference curve probably should be lowered between $-3 \mathrm{~m}$ to $-10 \mathrm{~m}$ to coincide with the approximate water level corrected for contained gas bubbles in the southeast vent at the time. At $-21.3 \mathrm{~m}$ in this southeast vent, for example, the interpreted evidence of boiling and abundant vapor suggests that existing pressures were only $\sim 50$ percent of the pressures assumed for the static liquid reference curve; presumably about half the length of the tube above the probe consisted of water vapor. Complex convection of water and vapor clearly was occurring in this vent, with hot two-phase flow entering the accessible geyser tube from one side (probably southeast) near $-21 \mathrm{~m}$.

The loss of the thermistor probe in Steamboat Geyser prevented further measurements, so we have no data that bear on the differences in behavior between major and minor eruptions, or between the minor eruptions of the 1970 's as compared with those of the 1960's and 1980's. In our opinion, the minor eruptions were triggered by surges at depth, possibly by vigorous convective overturn near $-20 \mathrm{~m}$ or by rapid ejection of water and steam from a side channel. Major eruptions probably evolve from minor ones after deeper levels have become sufficiently "loaded" and unstable to become involved (White, 1967).

A puzzling observation by R.O. Fournier (written commun., 1984) is that water collected from the discharge stream of major eruptions is more dilute and lower in geochemically indicated temperature than water from minor eruptions, but this explanation does not seem to satisfy the extreme vigor and long steam phase of the major eruptions. 


\section{STEAM VALVE GEYSER}

Steam Valve Geyser (pl. 1, E5 center) was conspicuous and noisy in the eariy days of the park but then became dormant, eventually being graded over and concealed by blacktop in 1930 as part of the then-current Norris Museum parking area.
On May 22, 1946, a mud volcano or geyser, considered to be a new feature, broke through the pavement of the parking area about $60 \mathrm{~m}$ south-southeast of the Norris Museum. This vent was called Steam Valve (fig. $35 A$ ), rejuvenated after the earlier named feature in the same area (Hague and others, 1904), and at first was reportedly similar to many small mud volcanoes and mud pots in the

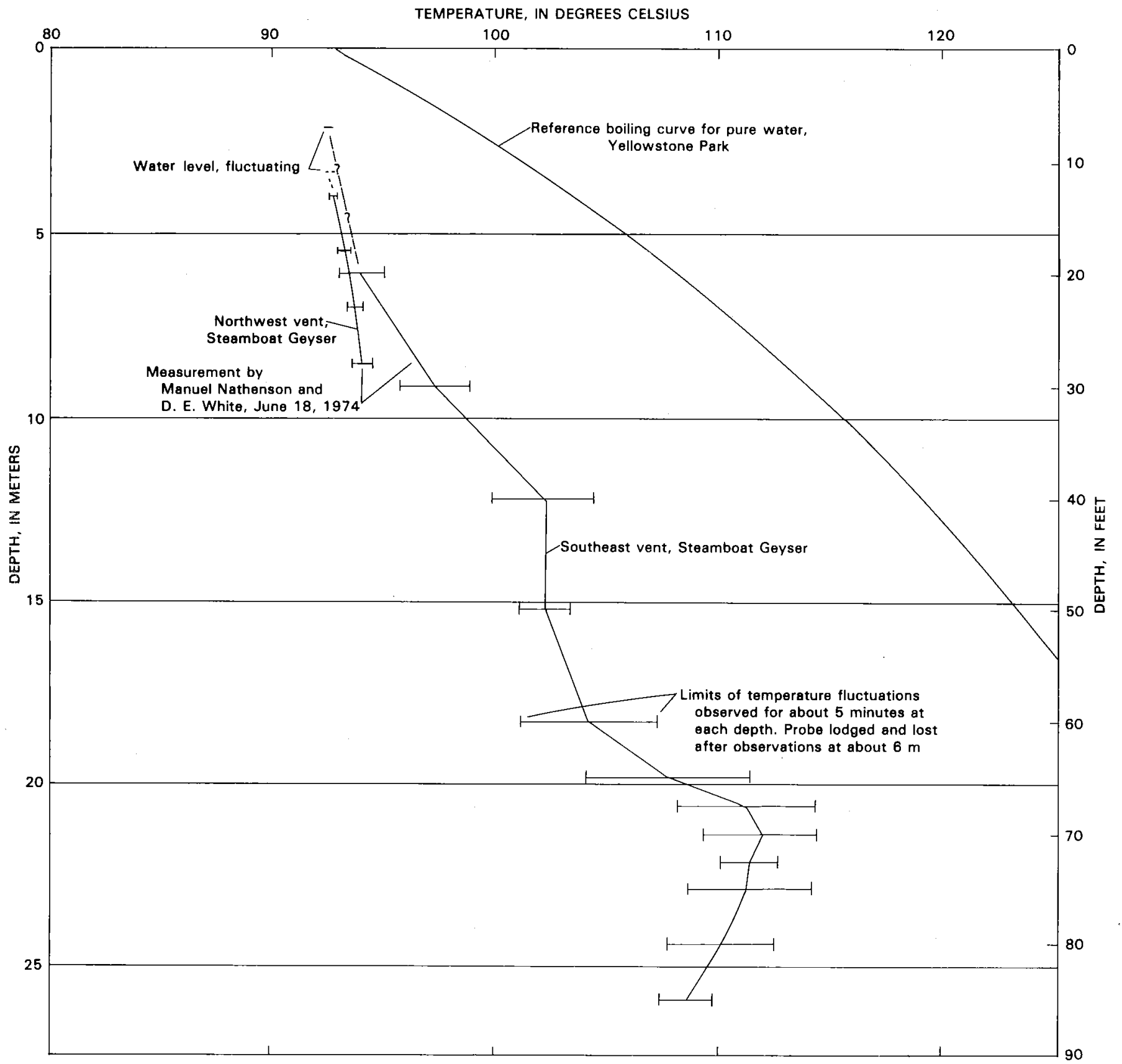

FIGURE 49.-Temperature-depth measurements from vents of Steamboat Geyser, Norris Geyser Basin. Depths and reference boiling curve refer to altitude below local sill level, $\sim 2,309 \mathrm{~m}(\sim 7,557 \mathrm{ft})$, at Steamboat Geyser. 
park, including Phillips Cauldron (pl. 1, G4-W; fig. 47), but it may have been a true small geyser. Steam Valve, however, was unusual in being observed from the inception of its renewed 1946 activity through its evolution and eventual demise (David Condon, Yellowstone informal records, 1947). Its altitude of $2,312 \mathrm{~m}(\sim 7,583 \mathrm{ft})$ is the highest of any recently discharging feature in Norris Basin, even exceeding Harding Geyser by about $4 \mathrm{~m}$. According to Condon, a tourist noticed a small crack form in the parking lot blacktop. Steam, water, and mud started to discharge and then flowed down the road to the major parking area $\sim 100 \mathrm{~m}$ to the west. Within 10 minutes the blacktop was locally broken up and a small crater $\sim 1 / 2 \mathrm{~m}$ in diameter started to eject muddy water while violent, turbulent action was rapidly enlarging the new vent. Within about 30 minutes, steam bursts and churning water had formed a crater nearly $1 \mathrm{~m}$ wide. The action continued to increase in intensity, undermining the blacktopped edges of the vent and ejecting debris on all sides. Within about $2^{1 / 2}$ hours the crater was 1.5 to $2 \mathrm{~m}$ in diameter; mud and water were intermittently ejected as high as $6 \mathrm{~m}$ and splashed down on the broad mud cone that was forming around the crater. In 6 hours the crater was almost $3 \mathrm{~m}$ in diameter and about $1 / 2 \mathrm{~m}$ deep. Undermining of the pavement continued for 48 hours (Turner, 1949, and Yellowstone informal records, 1947), when the crater was 4 to $5 \mathrm{~m}$ in diameter and $2 \mathrm{~m}$ deep. During the following month little further change occurred. Mild surging and erratic changes in water level characterized the activity, ranging from draining of the crater and refilling to various levels, boiling vigorously but not overflowing. During the remainder of the 1946 season the vent was periodically empty and then filled. In its early activity when ejected mud was abundant, this feature may have been a mud volcano, but it evolved to a boiling muddy pool with a high water content and eventually had intermittent turbulent water overflow that indicates a true geyser.

This feature seems not to have been mentioned for many years. It was still existing with mild nongeysering activity when first observed by D.E. White in 1947. Steam Valve is barely visible as an inactive open vent in the aerial photograph (fig. 50, lower right side) taken on September 1, 1959, after the Hebgen Lake earthquake of August 19, 1959.

Renewed activity similar to that of Steam Valve in 1946 occurred again in 1981-87 south of the Norris Museum, probably in its identical former location. At some time between 1959 and 1967 the former vent was again covered by blacktop, but when the new Norris bypass road and parking lot were constructed in 1967 (pl. 1, E5, E6) the blacktop was removed and the parking area was made to look as primitive as possible. On February 16, 1981, Steam Valve again broke out as a true geyser. This reactivated old vent was observed repeatedly by R.A. Hutchinson

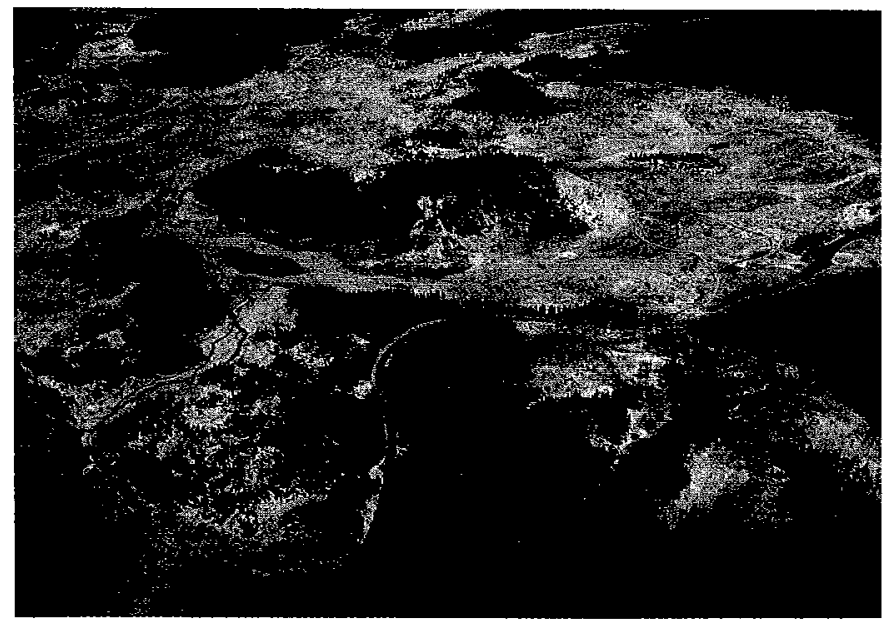

FigURE 50.-Aerial photograph of central Norris Basin, looking N. $5^{\circ}$ E. over part of Back Basin (pl. 1, E4 lower left), Porcelain Basin (pl. 1, D5 upper right), and the pre-1967 Norris Basin road and Norris Museum parking lots. Mottled alteration of cemented older Pinedale kames of Ragged Hills in lower left reflects differing degrees of convected heat flow in vapor, inversely related to density of pine trees. Photographed September 1, 1959.

(table 6) and later by D.E. White. Water rose intermittently from below ground level into the shallow basin, which filled, overflowed, and surged like a true small geyser. It erupted at intervals of 4 to 7 hours to heights near $3 \mathrm{~m}$, and it overflowed during each eruption for 20 to 40 minutes. By early 1982, its crater had dimensions of $4.6 \mathrm{~m}$ by $4.9 \mathrm{~m}$. Its behavior was approximately unchanged through late 1984, when its water level was 0.3 to $0.6 \mathrm{~m}$ below its discharge level. Its relatively long, complex history was evident from detailed examination of its photograph (fig. $35 B$ ).

\section{VIXEN GEYSER}

The vigorous but small Vixen Geyser (pl. 1, F4-SW; table 6; fig. 51) has two magnitudes of eruption-one that is normally short in duration and height and lacks discharge out of the immediate vicinity, and a rare second type that is longer in duration and height and discharges about $50 \mathrm{~m}$ to the northeast, to Tantalus Creek.

Lee Whittlesey, mentioned previously for his longstanding interest in Yellowstone's history and place names, has found obscure records in the National Archives indicating that P.W. Norris, the second Park Superintendent, supervised the removal of Vixen's natural 1-m-high cone and shipped it as a unique specimen to the U.S. National Museum. No direct confirming evidence for this early "official" action remains except, possibly, the unnatural-looking nearly square vent and a 


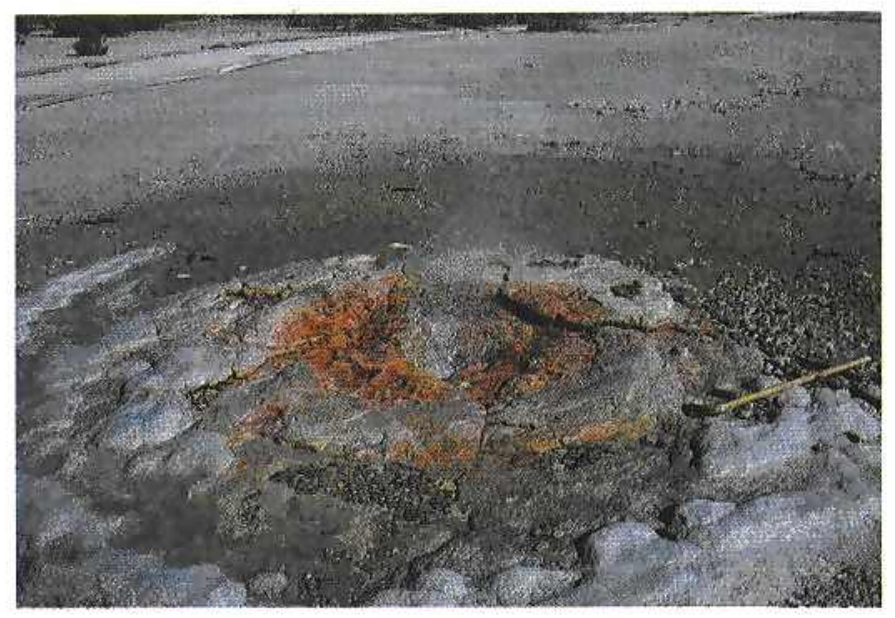

Figure 51.-Vixen Geyser (pl. 1, F4-SW) has two types of eruption, one normally with short rapid-fire pulses, height 2 to $5 \mathrm{~m}$ (as in this photograph), and with no external discharge beyond the wet white and green-brown area. A second rare type erupts 6 to $10 \mathrm{~m}$ and has external discharge northeast $\sim 50 \mathrm{~m}$ to Tantalus Creek. A central reddish-brown iron-stained area may mark the former location of a cone reportedly removed and sent to the National Museum. Photographed September 1984

surrounding iron-stained zone (fig. 51). The present surface in and near the vent is almost barren of young spinose sinter, characteristic of most acid $\mathrm{Cl}-\mathrm{SO}_{4}$ springs and geysers.

\section{WHIRLIGIG GEYSERS}

Whirligig Geyser (pl. 1, D5-W center; fig. 52) and Little Whirligig (fig. 53) are chemically typical of many springs and geysers in the flat-floored part of Porcelain Basin characterized by acid Cl-SO ${ }_{4}$ waters, morning-gloryshaped pools, and iron-rich sinters, some of which contain scorodite (Hague, 1887, an iron-arsenate mineral) in their discharge channels. Constant Geyser also shares these characteristics, as the three geysers differ mainly in regularity and detailed behavior. In recent years Little Whirligig has been the most regular and commonly observed, in part because of its proximity to the boardwalk through the central part of Porcelain Basin.

\section{OTHER NOTABLE FEATURES}

Many other thermal features are listed in tables 5 and 6. The Annex Area (pl. 1, D6; fig. 54) has acid $\mathrm{SO}_{4}$-Cl springs and abundant flocculated sulfur similar to Sulfur Dust Spring (pl. 1, A4; fig. 28). Primrose Springs (pl. 1, D5-E center; fig. 55) illustrates the intimate spacial association of different water types that exist in close proximity in parts of Porcelain Basin. Porcelain Springs, at the base of Porcelain Terrace (pl. 1, D6-W; fig. 56), have shown a similar chemical association that characteristically evolves rapidly with time.

The north inactive vent of Double Bulger (pl. 1, F4-SW; fig. 57) is a spectacular example of progressive infilling and self-sealing of a former flow channel. Probably the channels of many morning-glory-shaped pools, geysers, and nondischarging vents have a similar internal succession of sinter layers, but not normally revealed by erosion.

Several photographs illustrate different degrees of strong vertical and horizontal thermal gradients caused by differences in rates of conductive and convective heat flow (White, 1969, 1978). Y-12 drill hole (pl. 1, D6-NW;

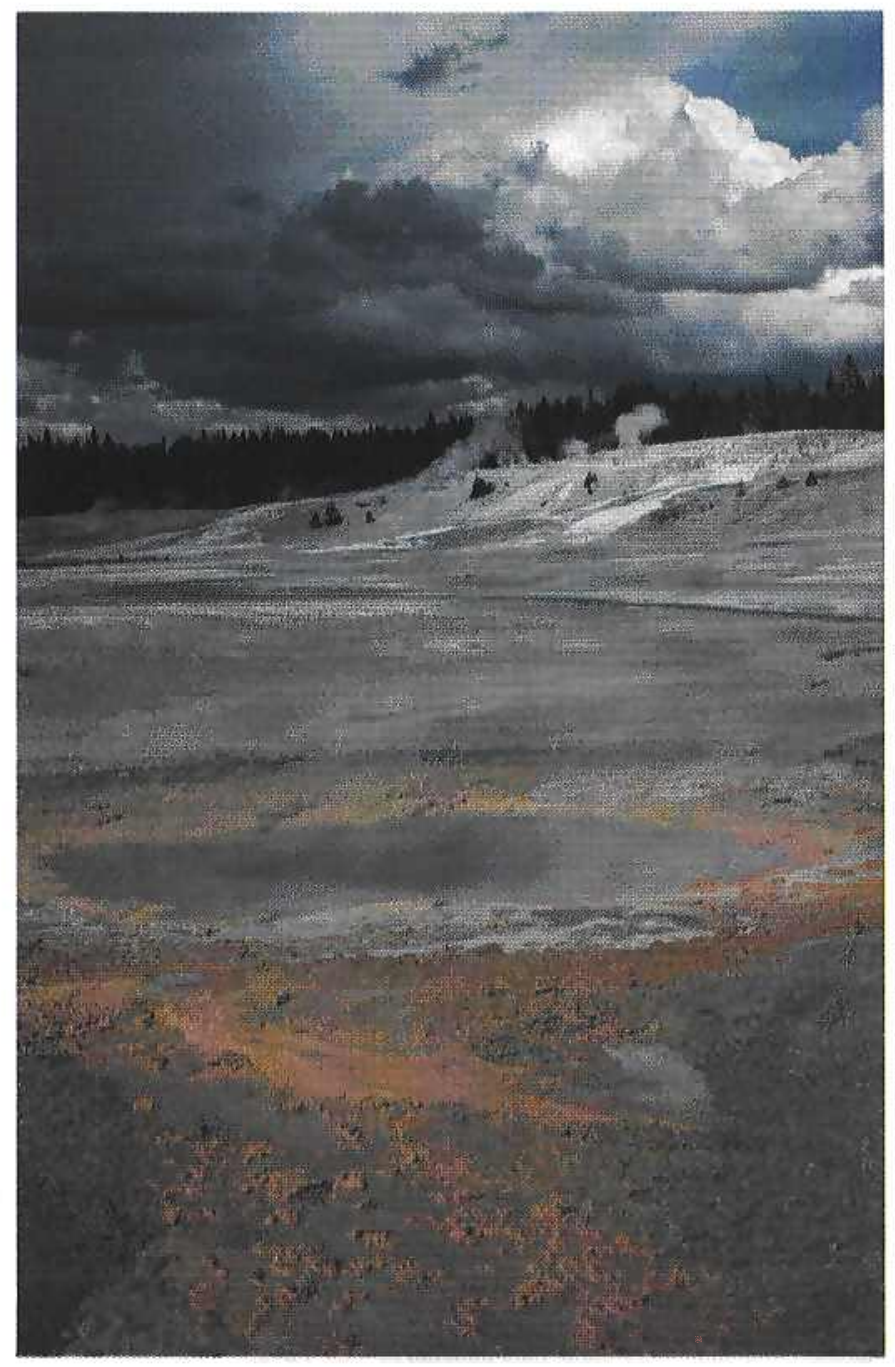

Figure 52.-Whirligig Geyser vent (pl. 1, D5-W center) almost drained after an eruption. Intense orange iron-rich sediment, deposited around the vent and in the discharge channel, is characteristic of many acid $\mathrm{Cl}-\mathrm{SO}_{4}$ springs. Photographed by Jennifer Whipple, August 1983. 
fig. 58) was intentionally located near the "treeline" heatflow contour, later calibrated by standard heat-flow methods as having a near-surface conductive heat flow of about $325 \mathrm{HFU}$ (or $\sim 13,600 \mathrm{~mW} / \mathrm{m}^{2}$; White, 1978).

An area of rapid melting of snow having an uncalibrated snowline heat-flow contour in warm ground northwest of

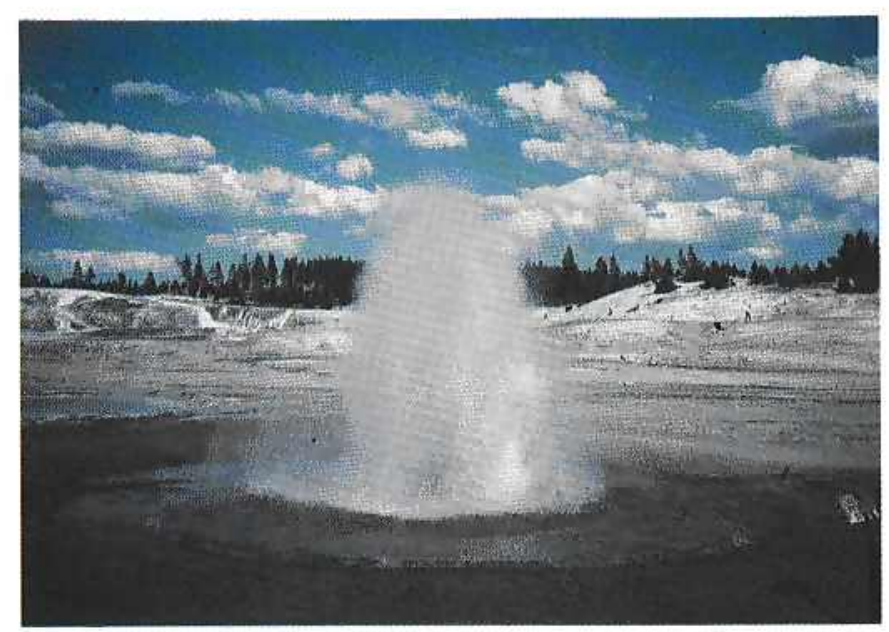

FIgUre 53.-Little Whirligig Geyser (pl. 1, D5-W center) in eruption about $5 \mathrm{~m}$ high, looking northeast over foreground of colored sinters deposited from acid Cl-SO $\mathrm{S}_{4}$ waters of Porcelain Basin. Acid-bleached Lava Creek Tuff (upper right) is thinly mantled sinter of Porcelain Terrace (behind and left of geyser plume); youngest sinter is white, older weathered sinter is medium to dark gray. Photographed summer 1946.

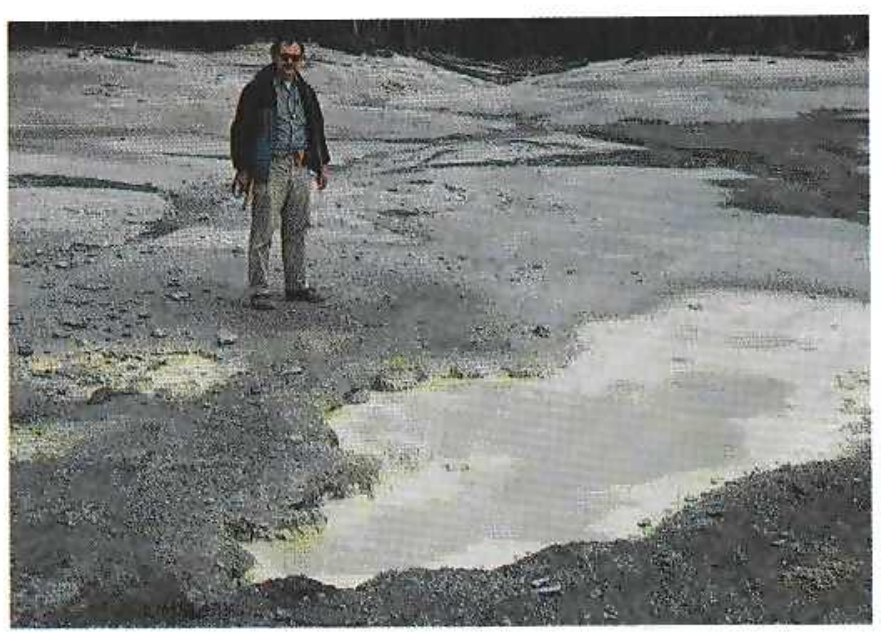

Figure 54.-Annex Area (pl. 1, D6-E center), east of Porcelain Terrace, emits mostly $\mathrm{H}_{2} \mathrm{~S}$ and other gases and minor $\mathrm{Cl}-\mathrm{SO}_{4}$ water. This spring has precipitated much elemental $\mathrm{S}$ (pale yellow), similar to Sulfur Dust Spring (fig. 28). Y-12 drill hole (pl. 1, D6-NW) was intentionally located between Porcelain Terrace and the Annex Area in a successful effort to obtain maximum temperatures in overpressured, nearly self-sealed Lava Creek Tuff. Photographed May 21, 1966.
Steamboat Geyser (pl. 1, E5-SW) is shown in figure 59. An interesting example of very high heat flow in Yellowstone Park is shown in figure 60 (note sudden decrease in the upper right corner of the photograph). The nearsurface thermal ground in the foreground is supported by convective upflow of vapor, from which water vapor

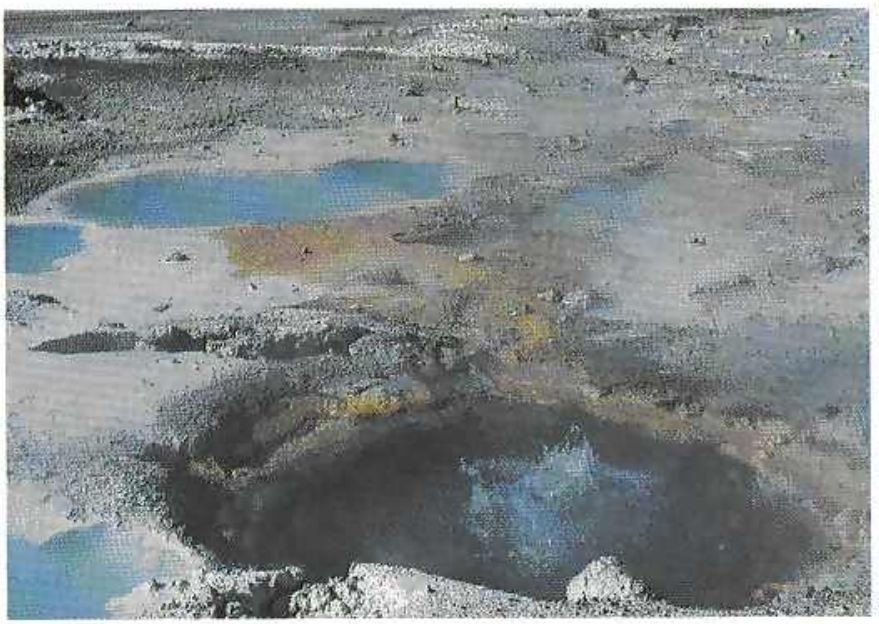

FiguRe 55.-Primrose Springs (pl. 1, D5-E center), showing contrasting colors characterized by varied chemistry of waters and inorganic precipitates. Black is FeS in near pool ( $\sim 1 \mathrm{~m}$ in diameter), browns are $\mathrm{Fe}$ oxides, and white and light gray are from precipitated colloidal $\mathrm{SiO}_{2}$. Photographed October 19, 1967.

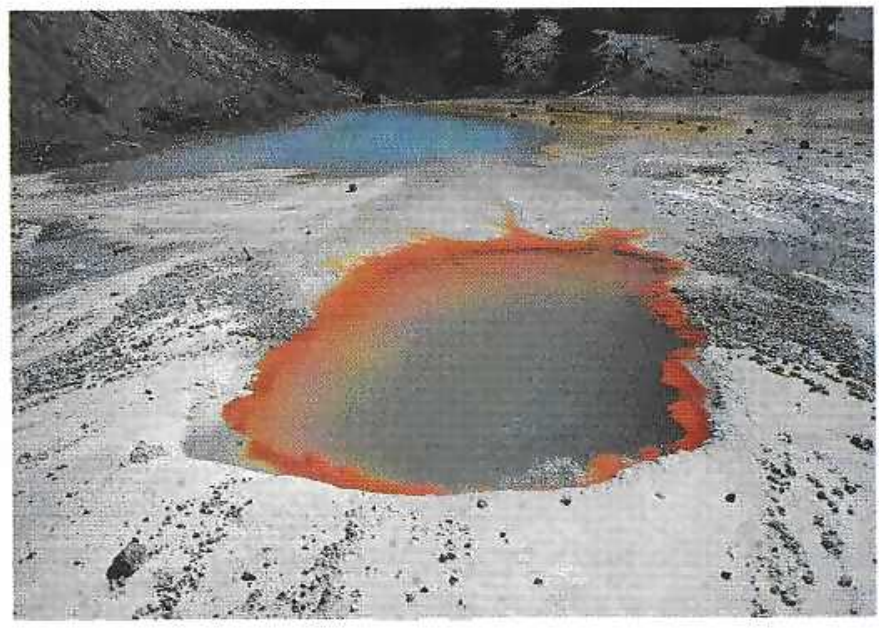

FIGURE 56.-Porcelain Springs (pl. 1, D6-W center) at base of Porcelain Terrace, showing nearest spring rapidly evolving from a neutral $\mathrm{Cl}-\mathrm{SiO}_{2}$ type to an acid $\mathrm{Cl}-\mathrm{SO}_{4}$ type, with $\mathrm{Fe}^{++}$oxidizing to $\mathrm{Fe}^{+++}$, seeping away from observer. Iron-stained, orange-bordered pool is about $1 \mathrm{~m}$ wide. Photographed August 1976. 
is selectively condensed to liquid at the ground surface, and the liquid then rapidly freezes if the air temperature is low enough. Upward growth of ice columns commonly carry small granules of sand or rock. A different exam-

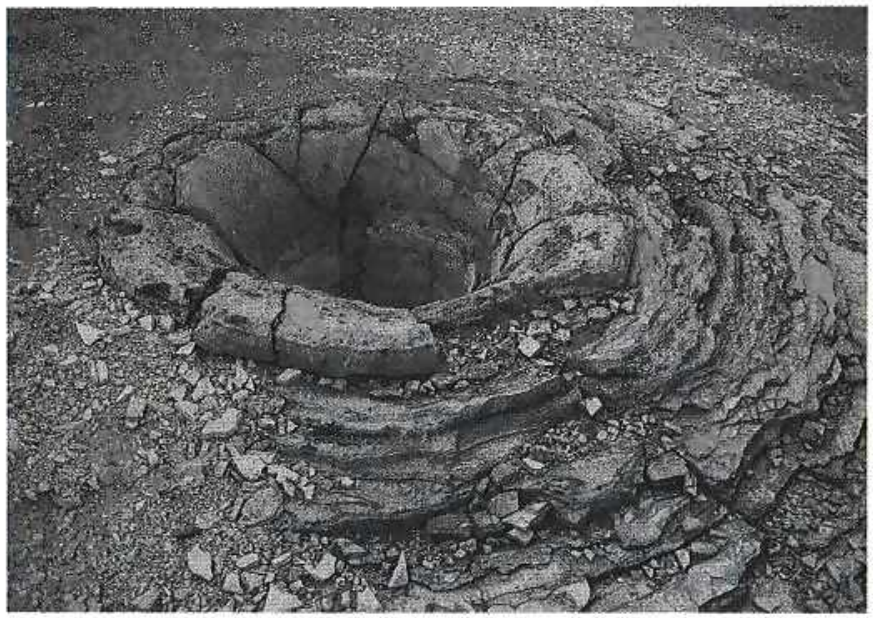

FiguRE 57.-Inactive so-called morning-glory vent of north Double Bulger (pl. 1, F4-SW), probably initially a geyser vent that became inactive as it was self-sealed by successive layers of sinter, inner diameter about $0.2 \mathrm{~m}$; surface layers of sinter and organisms were removed by weathering and wind. Colors are now in shades of gray. Many other vents may have similar layering but are not adequately exposed. Photographed May 25, 1966.

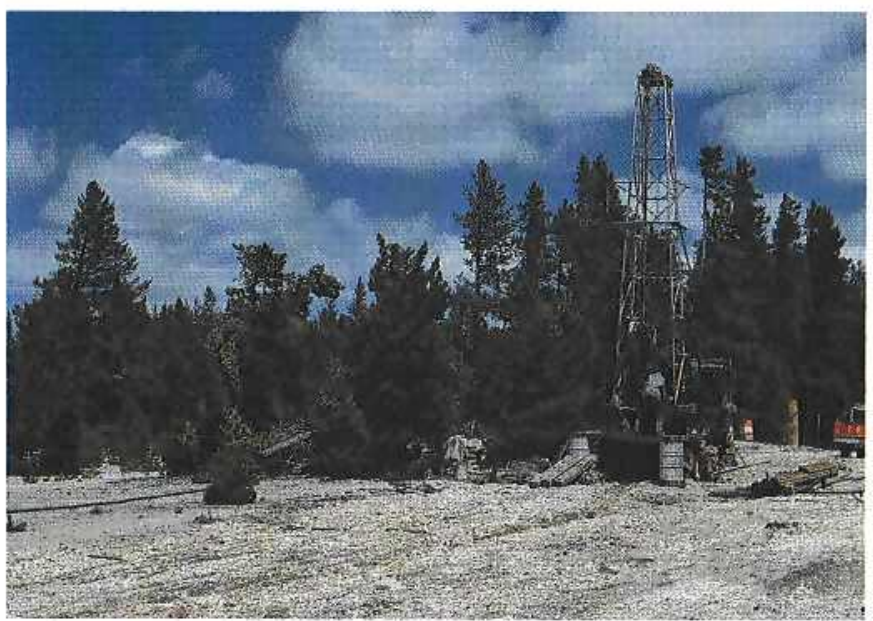

FIGURE 58.-Y-12 drill site (pl. 1, D6-NW) near so-called treeline heatflow contour ( $\sim 300 \mathrm{HFU}$; White, 1978, p. 769) 60 m east of Opal Spring, Porcelain Terrace. Foreground (hotter) supports grass but no pine trees. Hole had limited permeability to $\sim-30 \mathrm{~m}$ and was then almost completely self-sealed to its drilled bottom $(331.5 \mathrm{~m}$ and $237.0^{\circ} \mathrm{C}$, the highest temperature for its depth yet measured in a hydrothermal area). Photographed May 27, 1968. ple of the same general phenomena shown in figure 60 is shown in figure 61, except that drifting spray froze and formed a thick pile that melted in considerable part from its base.

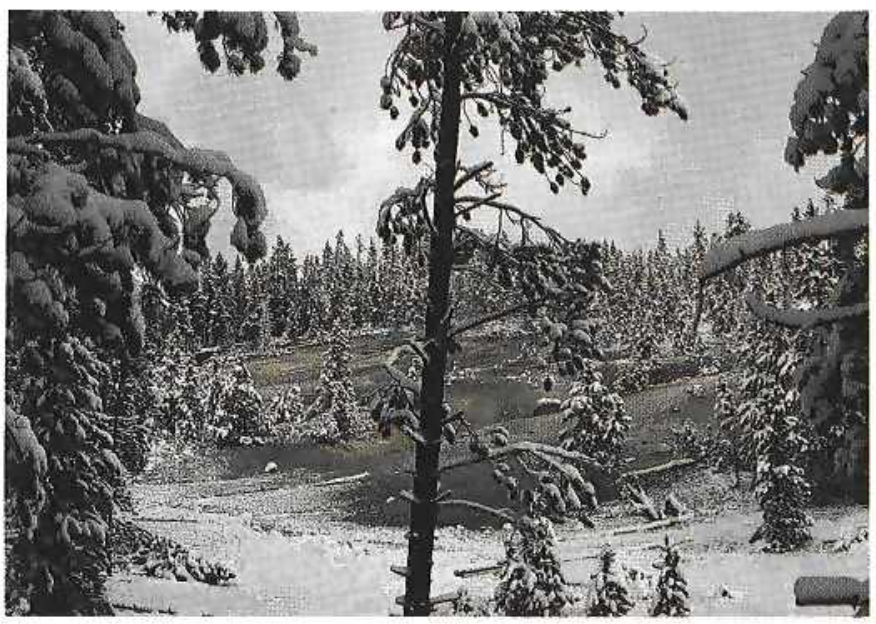

FIGURE 59.-Area north-northwest of Steamboat Geyser (pl. 1, E5-SW), where high heat flow has melted snow more rapidly than in adjacent areas. Note stunted trees and absence of other vegetation where heat flow and soil-zone acidity are too high for normal vegetation. Photographed October 2, 1969.

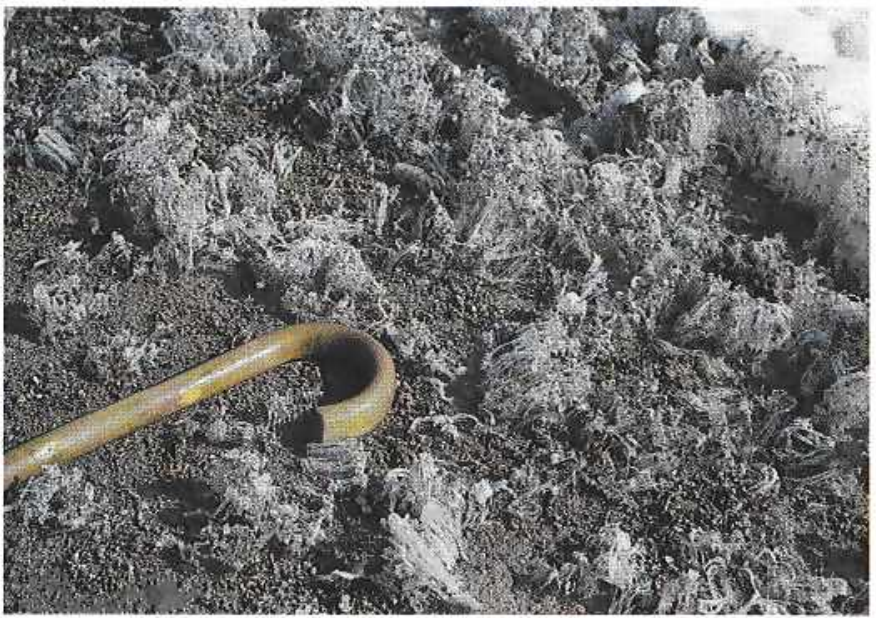

FIGURE 60.-Rime, or columnar ice, that grows upward from freezing of condensing convected water vapor at air-soil interface. Ice is supplied by minor upward-flowing water vapor and major other geothermal gases from which most heat and water vapor has already been lost, as along snowline shown in figure 59. Residual water vapor condenses and freezes in porous surficial soil. Individual ice columns incorporate sand grains and grow upward until they topple of their own weight. Photographed May 16, 1968. 


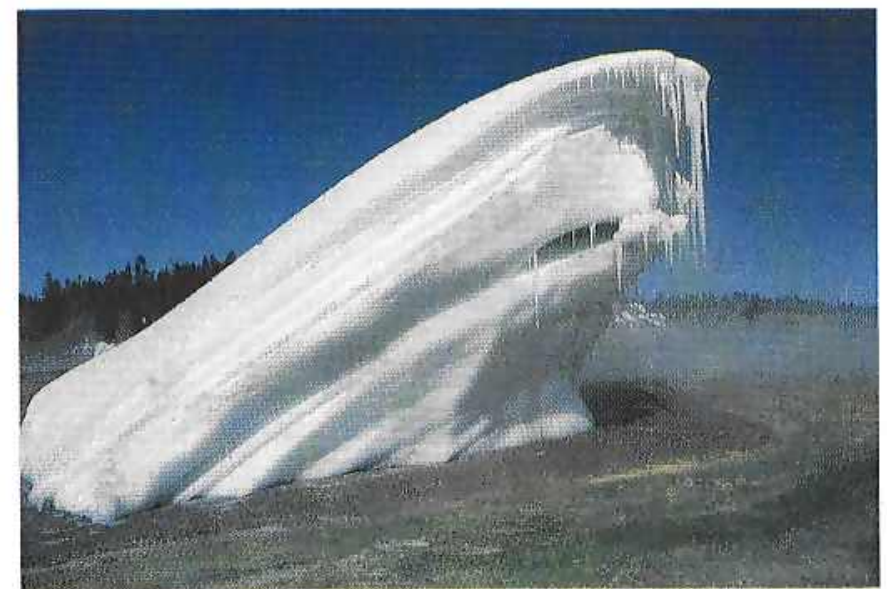

FIGURE 61.-Accumulated frozen spray about $4 \mathrm{~m}$ thick from Africa Geyser (pl. 1, D5-SW), melting mainly from base upward due to high near-surface heat flow in Porcelain Basin. Note basal discontinuity of snow layering and partial melting of layers adjacent to warm stream. Photographed April 1979.

\section{WIDESPREAD CONTEMPORANEOUS CHANGES}

Norris Basin, as previously noted, is characterized by frequent changes in activity. Many changes involve single features that are not obviously influenced by other nearby features. However, on some occasions nearly contemporaneous changes occurred over widespread parts of Porcelain and Back Basins, almost with annual frequency (table 8). A few of these have obvious causes, such as the major Hebgen Lake earthquake of August 17, 1959 $(M=7.1$; Marler, 1964; Trimble and Smith, 1975). However, many other events involving widespread changes have no obvious relation to detected seismic activity.

The Hebgen Lake earthquake affected most thermal features of the Firehole River geyser basins (Marler, 1964). However, only two Norris Basin geysers, Steamboat and Echinus, were obviously influenced judging from brief comments by naturalist Arthur Nash (Yellowstone informal records, Aug. 31, 1959). Steamboat's minor eruptions remained nearly the same, but its eruptions seemed higher and more water was ejected. Echinus Geyser's interval appears to have shortened from about 5 hours to 3 hours. Also, the water in all Norris geysers became noticeably turbid, ranging in color from milky white to slate gray. The water cleared up in all geysers within about 10 days.

R.O. Fournier (Morey and others, 1961; written commun., 1984) has commented informally that few hot springs were flowing in Norris Basin in 1960 as compared with 1965 and later years. Possibly the Hebgen Lake earthquake had affected more features than Nash had appreciated at the time; a higher earthquake-induced discharge rate may have been followed by a subnormal rate observed qualitatively by Fournier.
In contrast to the 1959 earthquake, the moderately strong earthquake of June 30,1975 ( $M=6.0$ to 6.1 ; Pitt and others, 1979) had an epicenter almost under Norris Basin, but no clear hydrothermal effects were identified by R.A. Hutchinson and other National Park Service observers (Yellowstone informal records, 1975). Thus, the widespread changes seem to show no clear relations to observed earthquakes.

After R.A. Hutchinson had noted the two widespread Norris disturbances of September 9-10, 1971, and August 8, 1972 (Yellowstone informal records), he and Norris naturalist Fred Hirschman searched old Norris records for evidence that other widespread disturbances had occurred previously. All known and suspected pre-1971 disturbances, as well as later disturbances that were observed within hours or a day or two after each event are listed in table 8. All disturbed features in the 1972 event were in Porcelain Basin, perhaps because the only regularly monitored feature in Back Basin was Echinus Geyser, which showed no certain change. During later years and closer observation, pronounced changes were generally identified in both subbasins, especially in the areas shown in blocks D5, D6, F4, and G4 of plate 1, and nearby ground. Generally only one disturbance was noted per year except for two each in 1974 and 1982, but none was identified in 1984. A one-day lag was indicated for extension of the disturbances from Porcelain Basin to the Back Basin in 1971.

Most widespread disturbances involved increased discharge, turbidity, and total geyser activity; those of 1971, 1976,1977 , and 1981 were followed within two to five days by suspected declines in total discharge to levels below normal.

All features affected by the widespread changes are within the broad north- to northeast-striking central belt of springs that extends from Hydrophane Springs (pl. 1, G3-E) to Porcelain Basin and adjacent Porcelain Terrace (pl. 1, E4, D5). This belt notably includes all neutral high $\mathrm{Cl}$-high $\mathrm{SiO}_{2}$ springs and geysers of Norris Basin, as well as many closely associated acid $\mathrm{Cl}-\mathrm{SO}_{4}$ springs and geysers. In contrast, neutral high-Cl waters are absent in the crudely parallel eastern and western belts.

A later section of this report presents possible reasons for the distribution of chemical water types, their changes with time, and also the restriction of widespread changes in activity to this central belt of thermal features.

Prior to 1982 attempts were made to remap changes that occurred in features shown on plate 1 . However, the major changes of 1982 and 1983 (table 8) finally forced us to realize that this map could never represent all features and all changes at any single time. The Hydrophane Springs belt (pl. 1, G3-E) and Porcelain Terrace and adjacent Porcelain Basin caused the most serious problems, indicated by notations in appropriate places on 
plate 1. Also, beginning in about 1984 Norris seasonal naturalists started recording many fewer natural changes than formerly, possibly due to lack of administrative pressure.

\section{ROCKS AND ALTERATION MINERALOGY OF DRILL HOLES, NORRIS GEYSER BASIN}

The physical results from drilling U.S. Geological Survey research drill holes Y-9 and Y-12 and a brief reinterpretation of data from Carnegie II (C-II) core (Fenner, 1936; White, 1955) are reported by White and others (1975) and are mentioned in earlier sections of this report.

The chemistry and mineralogy of the rocks and their hydrothermal alteration products in Norris drill holes are not as complicated as in most other Yellowstone drill holes because original rocks are all relatively unreactive, devitrified rhyolitic ash flows of the Lava Creek Tuff. The geochemistry and light stable isotopes of the fluid phases have been studied extensively by A.H. Truesdell, R.O. Fournier, and J.M. Thompson of the U.S. Geological Survey, and the results are planned for a later report.

Core recovery was over 98 percent from both Y-9 and Y-12. The core was logged at the drill sites by L.J.P. Muffler, D.E. White, A.H. Truesdell, and R.O. Fournier. Approximately 20 percent of each core set was selected for detailed study based on lithology and other features useful for interpreting the hydrothermal system. Core samples from C-II and field notes of C.N. Fenner were loaned by the Carnegie Institution of Washington to the U.S. Geological Survey. The amount of core recovered by Fenner was not recorded; the samples available are approximately 5 to $8 \mathrm{~cm}$ long and generally spaced at intervals of 0.3 to $1 \mathrm{~m}$.

Detailed laboratory investigations began with binocular microscope examination of selected core samples. Petrographic microscope and X-ray diffraction techniques were used to identify mineral phases and textural relations. Scanning electron microscope with attached energydispersive X-ray analysis was used to study several samples. Whole-rock chemical analyses for major oxides and trace elements were performed on selected samples; techniques and results are given in Beeson and Bargar (1984).

\section{LAVA CREEK TUFF}

The core samples from drill holes Y-9, Y-12, and C-II, except for thin glacial till in the top $1.2 \mathrm{~m}$ of Y-9, consist entirely of Lava Creek Tuff erupted in association with the collapse of the Yellowstone caldera approximately 630,000 years ago (table 1 ). The contact between member $\mathrm{B}$ (upper) and member A (lower) of the Lava Creek Tuff was identified by R.L. Christiansen (in White and others, 1975) at $-38.9 \mathrm{~m}$ in $\mathrm{Y}-9,-37.8 \mathrm{~m}$ in $\mathrm{Y}-12$, and -23.2 $\mathrm{m}$ in C-II; these contact depths are plotted to scale on figure 2. None of the three drill holes penetrated the base of the tuff.

Primary textures and mineralogy related to emplacement and cooling of the Lava Creek Tuff were described in detail from Y-5 drill core, Midway Geyser Basin (Keith and Muffler, 1978). The primary features of the ash-flow tuffs are similar in Y-5, Y-9, Y-12, and C-II, although the effects of hydrothermal alteration are somewhat different.

The Lava Creek Tuff in the Norris Basin drill cores is partially welded at the surface of all three holes and becomes more densely. welded with increasing depth; variations in degree of welding in the tuff are described by Christiansen (in press). Much of the tuff of member $B$ is crystal rich and contains pumice fragments that are compressed in the plane of eutaxitic foliation. A small but stratigraphically important part at the base of member $\mathrm{B}$ is crystal poor. Phenocrysts of fresh sanidine and quartz of the normal tuff are included in a fine-grained, devitrified groundmass comprised mostly of $\alpha$-cristobalite and sanidine. Initially, plagioclase (oligoclase) and mafic phenocrysts were present, but these have been removed or replaced during hydrothermal alteration. Primary clots of magnetite and zircon are locally unaltered.

Vapor-phase crystals are present in open spaces of the Lava Creek Tuff, mainly as euhedral, clear sanidine and tridymite crystals lining elongate cavities in the plane of eutaxitic foliation, in pumice fragments, and in intergranular pore spaces in the groundmass of the less densely welded tuff. Magnetite octahedrons exist as a late vaporphase mineral, but most magnetite has been hydrothermally altered to goethite.

Clear, stubby, euhedral quartz crystals 1 to $2 \mathrm{~mm}$ long are locally common in vapor-phase cavities and are usually at least partly coated with vapor-phase minerals. A similar occurrence of quartz has been described for Lava Creek Tuff in Y-5 drill core, where the term "granophyric" has been applied (Keith and Muffler, 1978). Granophyric quartz probably crystallized during the complex cooling history of the Lava Creek Tuff and is not considered strictly hydrothermal. Hydrothermal quartz in Y-9, Y-12, and C-II is clear and euhedral and was deposited later than vapor-phase minerals. Granophyric and hydrothermal quartz cannot always be easily distinguished in places where their relations to the vapor-phase period of crystallization cannot be established.

\section{HYDROTHERMAL ALTERATION}

Circulating fluids in the complex Norris hydrothermal system deposited secondary minerals in open spaces that 
include vapor-phase cavities, fractures, voids resulting from recrystallization of pumice fragments and leaching of phenocrysts, and pores in the groundmass. Total to partial replacement of phenocrysts and groundmass occurred locally. Alteration characteristics in the Lava Creek Tuff of drill holes Y-12 and C-II are similar, but Y-9 has significant differences. The general alteration characteristics are first described, and then specific additional characteristics are given for each drill hole. The secondary mineral distributions for each drill hole are shown on figures 62,63 , and 64 .

Three main stages of alteration have affected secondary mineralogy, as seen in the Norris drill cores. The first is an oxidizing stage that mobilized $\mathrm{Fe}$ and deposited ferric

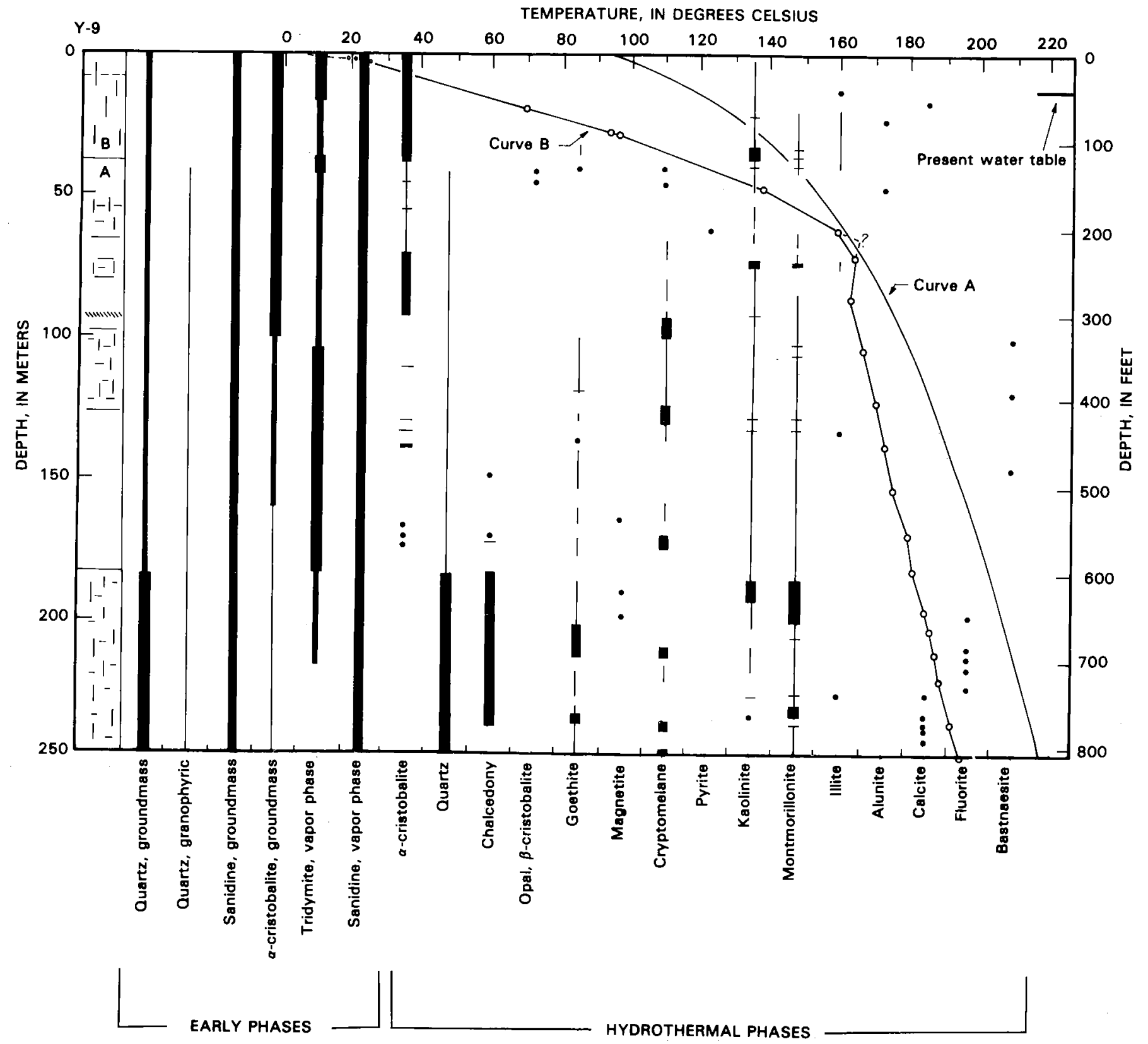

FIGURE 62.-Distribution of mineral phases produced during cooling and hydrothermal alteration of ash-flow tuffs of Y-9 drill hole. Column on left shows contact of members A and B of Lava Creek Tuff; highly fractured intervals, now largely self sealed, are hachured; initial water level is indicated by horizontal short dashed line. Curve A is reference boiling curve for pure water; curve B refers to selected measured temperatures as drilling progressed (from White and others, 1975 , p. 52). Abundance of minerals is shown qualitatively by thickness of vertical lines. 
oxides and hydroxides and local magnetite throughout the tuff, resulting in pinkish to red coloration of the rock. The second stage of alteration bleached the tuff to white or light gray and reduced $\mathrm{Fe}$ oxides to sulfides. The third is a surficial acid alteration that has extensively bleached the near-surface tuff to white.

The distribution of alteration minerals suggest that $\mathrm{Fe}$ mobilization occurred during an early period of pervasive alteration of the tuff. This alteration resulted in red, orange, yellow, brown, and black staining by Fe in the form of goethite, limonite, hematite, magnetite, and amorphous iron hydroxides. Iron oxides stain the groundmass, which remains otherwise unaltered, and also coat microfractures in phenocrysts, coloring them bright yellow to red. Goethite commonly is a thin coating over vapor-phase crystals and granophyric quartz in vapor-phase cavities. The red Fe-oxide staining of the groundmass normally has subhorizontal contacts with unstained tuff, but local ver-

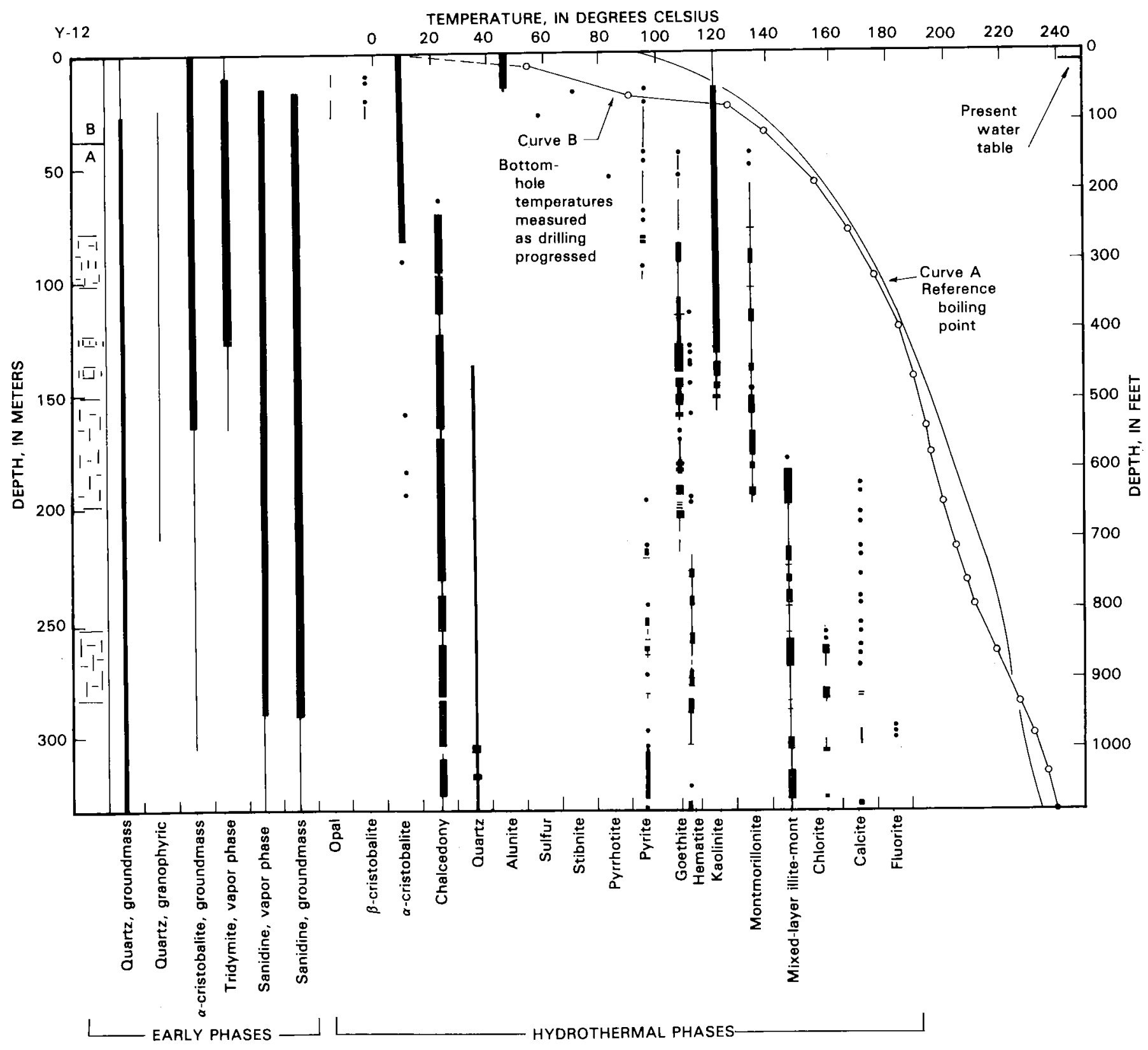

FIGURE 63.-Distribution of mineral phases produced during cooling and hydrothermal alteration of ash-flow tuffs of Y-12 drill hole. Patterns of left column, widths of vertical lines, and significance of curves A and B same as figure 62. (From White and others, 1975, p. 56). 
tical and irregular contacts indicate that $\mathrm{Fe}$ was also transported in solution along fractures. The Fe stainings and coatings are interpreted as occurring during the hydrothermal phase rather than vapor phase. Goethite, and locally hematite or magnetite, formed as early deposits on fractures through the tuff. Commonly the $\mathrm{Fe}$ oxide, along with chalcedony, forms dark-red veins in the deeper parts of the tuff. Clay and silica minerals form white vein deposits over the Fe-oxide coatings.

A second type of alteration, characterized by intervals of light-gray to white bleached tuff in Y-12 and C-II, has been superimposed irregularly upon reddish to pink ironstained tuff of the earlier $\mathrm{Fe}$-oxide stage. In places bleaching is clearly adjacent to major subvertical fractures; in other places bleaching is controlled by subhorizontal permeable zones comprised of elongate vapor-phase cavities and recrystallized pumice fragments. Locally, bleached tuff encloses isolated phenocrysts and small islands of tuff that still have red iron-oxide-coated microfractures. Fractures in the bleached rock are filled with clay minerals commonly associated with pyrite and silica minerals. Pyrite is disseminated in the groundmass, and, at depth in Y-12, chalcedony and quartz permeated the pore spaces of the tuff and evidently crystallized at the expense of $\alpha$-cristobalite and tridymite. Tuff in Y-9 was not affected by these bleaching fluids.

Y-12 and C-II drill cores locally contained pyrite that had been oxidized to goethite and other $\mathrm{Fe}$ oxides in previously bleached intervals. Though this overprint is minor and not easily recognized, the pattern shows that hydrothermal fluids of changing composition had access to the rock, or more likely, the system was sealed for some time and then refractured, permitting access of a different or modified fluid. Rocks did not always reach equilibrium with the fluids because of continuing self-sealing and refracturing. Thus, in detail, a complex signature is seen

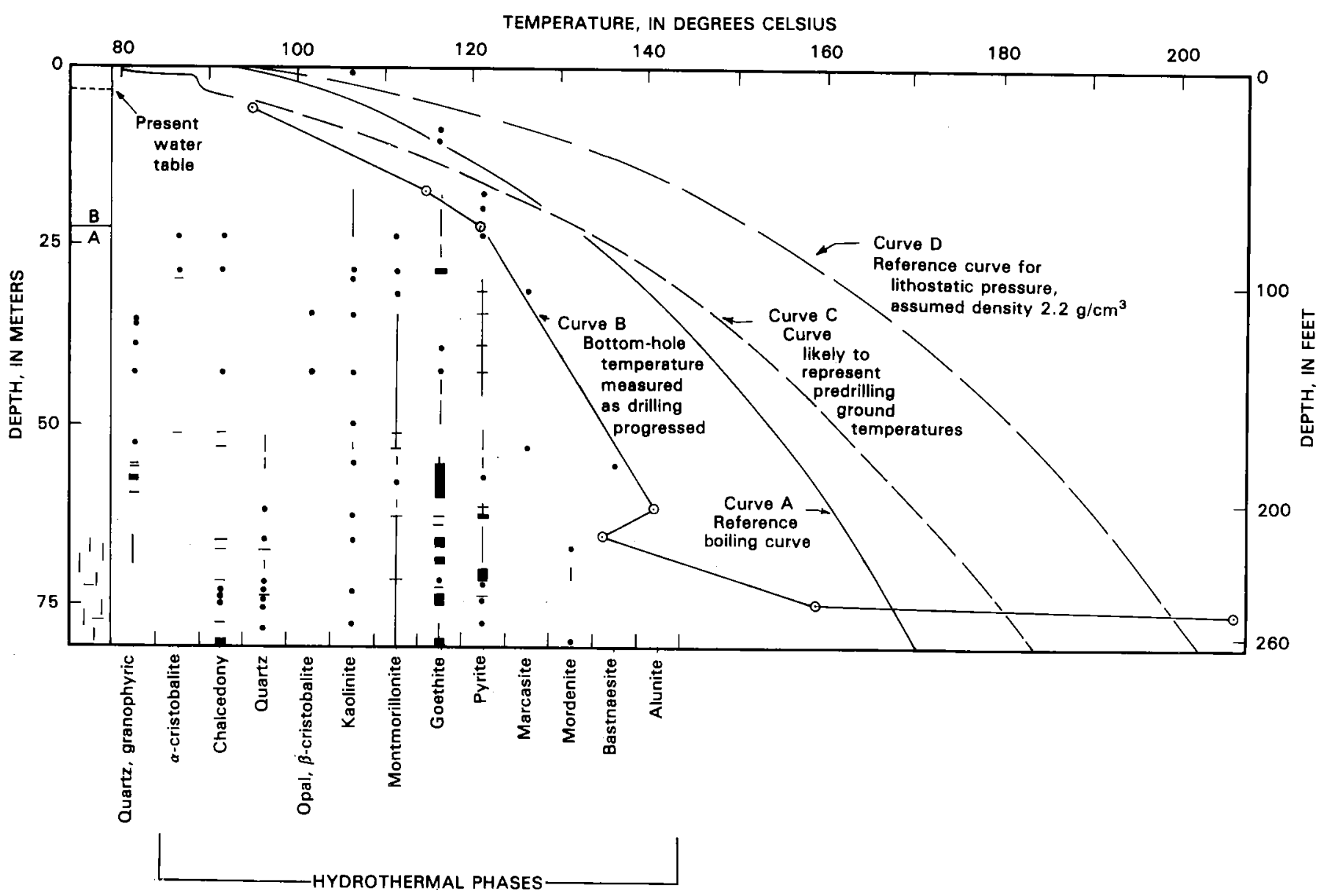

FIGURE 64.-Distribution of mineral phases produced during cooling and hydrothermal alteration of ash-flow tuffs of Carnegie II drill hole. Patterns of left column, widths of vertical lines, and significance of curves A and B same as figures 62 and 63 . Curve C approximates predrilling ground temperatures, and curve D, the reference curve for lithostatic pressure, assuming rock density of $2.2 \mathrm{~g} / \mathrm{cm}^{3}$. 
in the mineralogy for different hydrothermal fluids involved in rock alteration.

Surficial acid alteration, the third stage, was recognized in the upper parts of all three drill cores. This type of alteration is characterized by late deposition of clear, tiny, euhedral crystals of $\mathrm{K}$-alunite lining open fractures in the upper $16.8 \mathrm{~m}$ of $\mathrm{Y}-12$ and part of the open-space crystallization in altered glacial deposits in the upper $1 \mathrm{~m}$ of $\mathrm{Y}-9$ and C-II. Fractures filled with opal, $\beta$-cristobalite, $\alpha$-cristobalite, and kaolinite also cut the bleached nearsurface tuff. Altered tuff in the near-surface zone is chalky white and is comprised of unaltered quartz phenocrysts and partly altered sanidine and $\alpha$-cristobalite from the devitrified groundmass, as well as sanidine and tridymite from vapor-phase cavities. Hydrothermal kaolinite and silica ( $\alpha$-cristobalite in shallow parts and chalcedony in deeper parts) are late alteration deposits below the surficial alunite and extend deeper into the tuff as fracture fillings and locally as pore fillings. Kaolinite decreases in abundance at depth. In Y-12, pyrite is abundant along fractures in the surficial acid-altered zone below the alunite level, occurring with kaolinite and $\alpha$-cristobalite or chalcedony. Near the surface, earlier Fe-oxide alteration has been obliterated except for sporadic faint relicts.

The Lava Creek Tuff crystallized during emplacement and throughout a long period of cooling of the ash-flow sheets. Primary mafic minerals were the least stable in the hydrothermal environment and thus were readily altered; however, the feldspars and silica minerals were generally stable to metastable. Mafic phenocrysts in the tuffs, initially mostly ferroaugite and minor fayalitic olivine, hornblende, and local chevkinite and allanite (Christiansen, in press), have been leached entirely, leaving goethite as a local partial replacement product. Relict outlines of mafic minerals are recognized in the Fe-oxidestained intervals of the cores, and primary magnetitezircon clots are preserved in $\mathrm{Fe}$-oxide-stained intervals where little additional alteration has occurred.

Plagioclase (oligoclase) phenocrysts have been totally leached from all the Norris Basin cores, leaving rectangular cavities. In the shallower parts of Y-9 and C-II the cavities remain empty; however, in most of the cores, the cavities are filled with clay minerals structurally similar to the clays coating nearby fractures. In the upper parts of each drill hole, white fine-grained smectite, kaolinite, and silica ( $\alpha$-cristobalite, $\beta$-cristobalite, and opal) fill the cavities. In most of the core from Y-9 and C-II, the cavities are filled with smectite. With increasing depth, clay minerals in Y-12 become mixed-layer smectiteillite, as in the fractures, with the illite component increasing downward relative to smectite. The clay mineral filling cavities after leached plagioclase phenocrysts in the bottom part of Y-12 is approximately 95 percent illite. The clays may have replaced plagioclase phenocrysts, but if so, plagioclase is completely replaced, even in the least altered rocks. The clay minerals in fractures formed later than the early Fe-oxide minerals on the borders of the fractures. Therefore, the plagioclase must have been leached before or during $\mathrm{Fe}$-oxide deposition and the clay minerals deposited later in the cavities and along fractures.

Sanidine phenocrysts generally were not altered in any core samples, except for partial leaching in surficial acidaltered tuffs and extensive alteration below $-256 \mathrm{~m}$ in Y-12.

Quartz phenocrysts persist unaltered except in the strongly bleached, acid-altered surficial part of Y-12, where they are not structurally changed but the color is pale lavender instead of clear.

Much of the groundmass is unaltered and remains as a fine-grained devitrified mixture of metastable $\alpha$-cristobalite and sanidine. Groundmass affected only by the Fe-oxide-bearing fluids and groundmass of the most bleached samples, such as the shallow part of Y-9 and numerous parts of $\mathrm{Y}-12$ and C-II, show no detectable differences in mineralogy by X-ray diffraction. With increasing depth in Y-9 and Y-12, quartz becomes increasingly more abundant in the groundmass, and tridymite disappears (figs. 62,63 ). Also with increasing depth, $\alpha$-cristobalite in the groundmass steadily decreases downward in abundance in Y-9 and disappears in Y-12. Sanidine in the groundmass remains constant in abundance throughout this change in silica minerals. Although the change with depth of $\alpha$-cristobalite and tridymite to quartz must be a hydrothermal process, no conversion of sanidine to adularia has been observed. The groundmass sanidine has been partly to totally leached in the lower part of Y-12 where sanidine phenocrysts have been partly leached. Groundmass alteration is pervasive in the white, bleached, surficial acid-altered intervals, especially the upper 16.8 $\mathrm{m}$ of Y-12 where sanidine and tridymite appear to have been partly removed but $\alpha$-cristobalite remains unaltered.

Locally in the Y-9 and Y-12 cores, steeply dipping fractures approximately $10 \mathrm{~mm}$ wide are filled with finegrained, mostly pink kaolinite, $\alpha$-cristobalite, chalcedony, and Fe oxide. Fragments of brecciated tuff locally form a part of the fracture fill. Similar brecciated fracture fill in the Y-5 drill core was explained by hydrofracturing and filling with an amorphous silica floc (Keith and Muffler, 1978). The fracturing and infilling of the fractures in the Norris cores probably occurred in a similar manner.

Whole-rock analyses of major oxides from the Norris drill core samples (Beeson and Bargar, 1984) are remarkably similar, showing little difference in $\mathrm{SiO}_{2}$ and $\mathrm{Al}_{2} \mathrm{O}_{3}$, but slight variations in $\mathrm{Fe}_{2} \mathrm{O}_{3}: \mathrm{FeO}, \mathrm{Na}_{2} \mathrm{O}: \mathrm{K}_{2} \mathrm{O}: \mathrm{CaO}$ occur, and $\mathrm{MgO}$ and $\mathrm{CaO}$ decrease in the bleached zones. Analyses of unaltered Lava Creek Tuff, for comparison, are given by Christiansen (in press). Compared to 
unaltered rock, near-surface acid-altered tuff shows the most change in chemical composition, as expected.

Trace-element compositions of the altered rocks show local differences of interest (Beeson and Bargar, 1984). In $\mathrm{Y}-9, \mathrm{Ba}$ and $\mathrm{Sr}$ are concentrated in cryptomelane, and the corresponding whole-rock analyses show enrichment in $\mathrm{Ba}$ and $\mathrm{Sr}$ (along with $\mathrm{Mn}$ and $\mathrm{K}$ ). All three drill holes have intervals in which rare-earth elements (REE), particularly $\mathrm{Ce}$, La, and $\mathrm{Y}$, are enriched relative to most whole-rock analyses of drill core. In Y-9 and C-II, tiny $(10-80 \mu \mathrm{m})$ euhedral crystals of the Ce- and La-rich carbonate bastnaesite (fig. 65) were found in the REEenriched intervals. The crystals were deposited on crusts of Ce-rich goethite, which was deposited on vapor-phase tridymite. The rare-earth elements were probably derived from primary allanite and chevkinite, which were hydrothermally altered. Ag is locally enriched in near-surface altered tuffs of Y-9 and Y-12 (Beeson and Bargar, 1984). Unaltered Lava Creek Tuff shows wide variations in trace-element composition (Christiansen, in press), so we conclude that sufficient amounts of trace elements are available in unaltered tuffs to be hydrothermally reconcentrated into secondary minerals in the altered tuffs without transport over great distances.

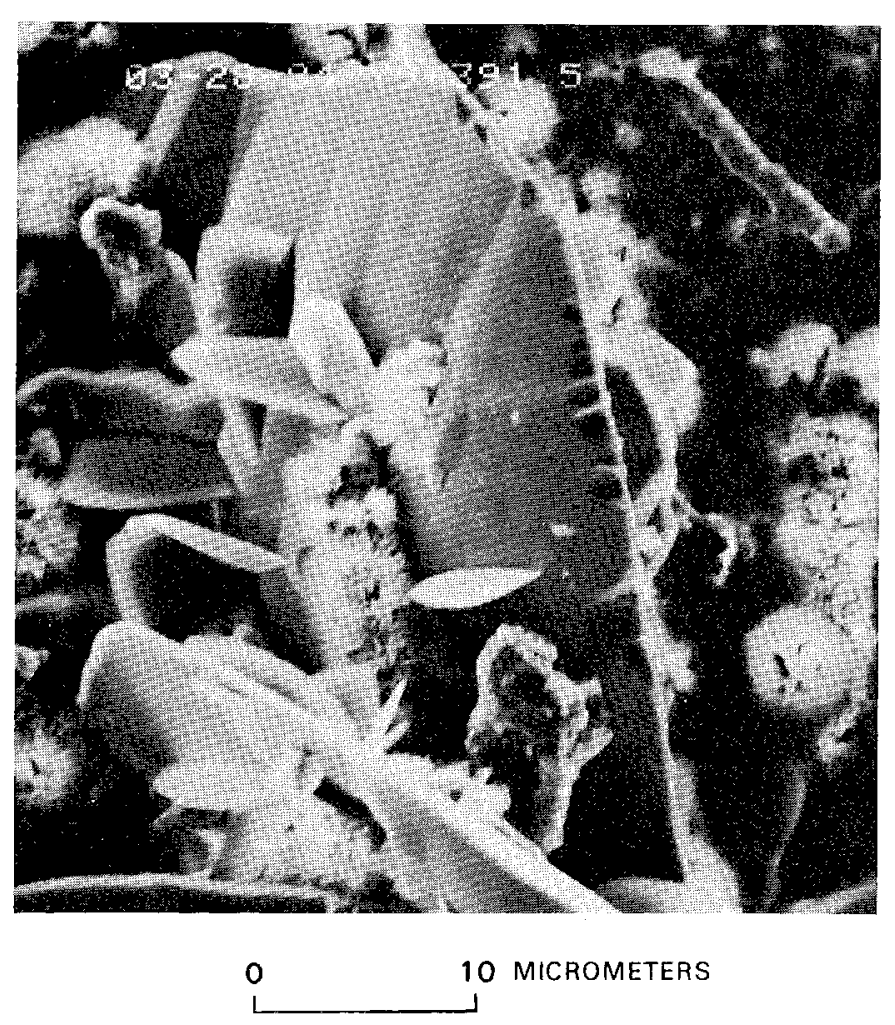

FiguRE 65.-Scanning electron micrograph of bastnaesite, a Ce- and La-rich carbonate, from $-119.3 \mathrm{~m}(-391.5 \mathrm{ft})$ in drill core Y-9. Photomicrograph by Robert Oscarson, U.S. Geological Survey, 1984.
CHARAGTERISTICS OF THE DRILL GORE FROM Y-9

The first $1.2 \mathrm{~m}$ of Y-9 drill core consists of acid-altered glacial deposits, largely derived from Lava Creek Tuff. Fine-grained alunite and kaolinite have been deposited along fractures and have replaced part of the groundmass in poorly cemented glacial material.

Irregular bleaching of member B of the Lava Creek Tuff by acid fluids extends to $-23.8 \mathrm{~m}$. Color of the tuff is white where heavily bleached (fig. 3) and grades from white to lavender to gray where bleaching decreases. $\mathrm{X}$-ray diffractograms of the groundmass show no significant differences in mineralogy between bleached and unbleached tuff, nor have the primary textures changed. Major fractures in member $\mathrm{B}$ are steeply dipping, as wide as $2.5 \mathrm{~cm}$, and filled with hydrothermal $\alpha$-cristobalite and kaolinite and locally crushed wallrock. Hydrothermally deposited, amorphous, yellow Fe hydroxides color the filled fracture and vapor-phase cavities.

Hydrothermal alteration in member A, below $-23.8 \mathrm{~m}$ to the bottom of the drill hole, consists mainly of red, orange, yellow, brown, and black deposits and stains of Fe and Mn oxides. Major effects of alteration fluids in the deeper parts of Y-9 are confined to fractures and vaporphase cavities where secondary minerals crystallized in open spaces; however, the tuff groundmass is mostly stained to brick red or pink from remobilized Fe. Fractures in member A are mostly steeply dipping to vertical, or parallel to subhorizontal flow banding along compressed vapor-phase cavities and recrystallized pumice fragments. Goethite, combined locally with hematite or magnetite, coats the earliest fractures and vapor-phase cavities. Some intervals have black cryptomelane instead of goethite and some have both (fig. 62). As in the shallower fractures, clays and silica were deposited later than goethite and cryptomelane.

In Y-9 drill hole the dominant clay mineral is kaolinite in the upper part of the core and montmorillonite in the lower part. Kaolinite is present in veins, cavities, and pore spaces from near the surface to $-232.6 \mathrm{~m}$, but is scarce below $-195 \mathrm{~m}$ (fig. 62). Kaolinite fills relict cavities from leached plagioclase phenocrysts throughout the tuff to $-209.7 \mathrm{~m}$, below which both montmorillonite and kaolinite fill the cavities. The kaolinite is structurally well ordered, as determined by X-ray diffraction. Montmorillonite occurs as late deposits on Fe-oxide-coated fractures and in pore spaces in the groundmass below the near-surface acid-altered interval. No systematic transition to mixed-layer clays takes place with depth; however, traces of mixed-layer clays and illite are in the groundmass below $-200.2 \mathrm{~m}$, where temperatures are 180 to $198^{\circ} \mathrm{C}$. Illite in the upper $36.6 \mathrm{~m}$ may be related to an earlier alteration stage. 
The hydrothermally deposited silica phases are dominantly $\alpha$-cristobalite in the upper part and chalcedony and quartz in the lower part of the drill hole (fig. 62). Below $-23.8 \mathrm{~m}$ and throughout member $\mathrm{A}$, the groundmass increases in quartz content and decreases in $\alpha$-cristobalite with depth. Hydrothermal quartz is an early alteration phase, crystallizing locally on vapor-phase minerals below $-41.1 \mathrm{~m}$. Vapor-phase tridymite has been removed below $-225 \mathrm{~m}$. Hydrothermal $\alpha$-cristobalite is scarce below $\sim-100 \mathrm{~m}$, except for local fracture fillings, and is not found below $-172.6 \mathrm{~m}$. Chalcedony is the dominant silica phase in fractures as high as $-148.3 \mathrm{~m}$ and is the only silica phase in fractures below $-172.6 \mathrm{~m}$ (although euhedral hydrothermal quartz is moderately abundant in cavities). Normally chalcedony is dark red due to abundant tiny red inclusions of Fe oxide.

Fluorite and calcite have not been observed together in Y-9, therefore their relative paragenesis cannot be determined. Where they are present, each is the last hydrothermal mineral to have been deposited, and neither is abundant. Aside from a few small bladed crystals, calcite occurs as very thin deposits on irregular small fracture surfaces at $-224.6 \mathrm{~m}$ and below. Fluorite exists as clear, euhedral crystal groups as large as $3 \mathrm{~mm}$ on a side on Fe oxides in cavities between -197.5 and $-222.5 \mathrm{~m}$.

No active surficial features are present near Y-9. Active hydrothermal circulation and alteration are absent in all of Y-9 at depths below about $-85 \mathrm{~m}$, where the thermal gradient is nearly linear. The presence of illite in the upper parts of the drill core suggests that it must have been deposited by an earlier alteration stage at a time when glacial cover was much thicker and temperatures were hotter than at present. The abundant quartz, chalcedony, and kaolinite, and fluorite below - $185 \mathrm{~m}$ are hydrothermal phases but are presumably relict from an earlier system, perhaps early Pinedale or pre-Pinedale in age. This deep zone must initially have been a very permeable fracture zone but has been self-sealed suffiently long for a constant thermal gradient to be established. Present waters below $-100 \mathrm{~m}$ were never successfully sampled, but dilute acid-sulfate waters from Norris Dome are suspected.

\section{CHARACTERISTICS OF THE DRILL CORE FROM Y-12}

Minerals formed by acid alteration permeate the upper part of Y-12 drill core (fig. 63), including all of member $\mathrm{B}$ and the top of member A of the Lava Creek Tuff to $-45.7 \mathrm{~m}$. Near-surface fractures are mostly vertical and filled with opal, $\beta$-cristobalite, $\alpha$-cristobalite, kaolinite, and clear, euhedral K-alunite. Alunite and the silica minerals were deposited later than kaolinite. Fractures in acidaltered tuff below $-15.2 \mathrm{~m}$ and extending to $-83.8 \mathrm{~m}$ are lined with kaolinite, $\alpha$-cristobalite, $\beta$-cristobalite, and opal; pyrite is abundant on and within the later layers of silica. A thin black coating of stibnite(?) over pyrite is present as a late deposit at $-16.2 \mathrm{~m}$. Tiny crystals of native sulfur have crystallized on tarnished pyrite and on an open fracture surface at $-20 \mathrm{~m}$. Quartz phenocrysts are not leached but have a pale-lavender color instead of being clear.

From -77.7 to $-100.6 \mathrm{~m}$ and from -120 to $-200 \mathrm{~m}$ subvertical fractures as wide as 2 to $3 \mathrm{~cm}$ are filled with fine-grained chalcedony and goethite, and locally angular wallrock fragments. The tuff and fracture fill is pink to brick red because of oxidation of $\mathrm{Fe}$ minerals to ferric oxides. Later bleaching solutions locally penetrated this section of tuff irregularly, cutting subhorizontally across both fracture filling and tuff. The bleached rock is almost white, and the $\mathrm{Fe}$ oxide from early alteration is replaced by pyrite. The latest observed alteration occurred as bleaching solutions locally circulated along reopened subvertical fractures at -87 to $-95 \mathrm{~m},-137$ to -152 $\mathrm{m}$, and -181.5 to $-195 \mathrm{~m}$, where deposition of a cryptocrystalline mixture of white kaolinite, $\alpha$-cristobalite or chalcedony, and minor montmorillonite show a distinct superposition of acid alteration upon the earlier alteration (fig. 66).

Fracture filling below $-200 \mathrm{~m}$ in oxidized intervals consists mainly of goethite (locally hematite or magnetite), chalcedony, and mixed-layer illite-montmorillonite and in bleached intervals the filling consists of pyrite, Fe-bearing mixed-layer illite-montmorillonite and locally chlorite (fig. 63).

Plagioclase phenocrysts throughout Y-12 were leached during an early alteration stage. The relict cavities are filled with montmorillonite and kaolinite in the upper part of the drill core and with mixed-layer montmorilloniteillite in the lower parts. Sanidine phenocrysts have been partly to totally leached in the lower part of the hole, leaving thin white septa of illite crossing the rectangular cavities. The septa developed by filling cracks and cleavage planes in sanidine phenocrysts, followed by dissolution of most remaining sanidine. Calcite blades have crystallized locally in the rectangular cavities left by leaching of sanidine. Mafic phenocrysts have been mostly obliterated except near the bottom of the hole, where phenocryst outlines remain but are replaced by $\mathrm{Fe}$ oxides and Fe-rich clays.

Because of the greater drilled depth and higher temperatures of Y-12 relative to the other Yellowstone drill holes, clay mineralogy shows effects not seen in Y-9 and C-II. Kaolinite is the most abundant clay mineral in the surface acid-altered zone, as in the other two Norris drill holes. Kaolinite decreases in abundance downward, but persists in late-stage fractures to $-158 \mathrm{~m}$. Montmorillonite exists with kaolinite at depth and becomes dominant from -156.4 to $-196.6 \mathrm{~m}$, where montmorillonite begins to change to mixed-layer montmorillonite-illite. The 
illite component increases downward relative to montmorillonite. No discrete illite was identified, although below $-305 \mathrm{~m}$ glycollated samples indicated only 2 to 5 percent of interlayered montmorillonite (using the figures of Weaver, 1956). Chlorite locally crystallized in veinlets in bleached intervals below $-264 \mathrm{~m}$, typically with pyrite.

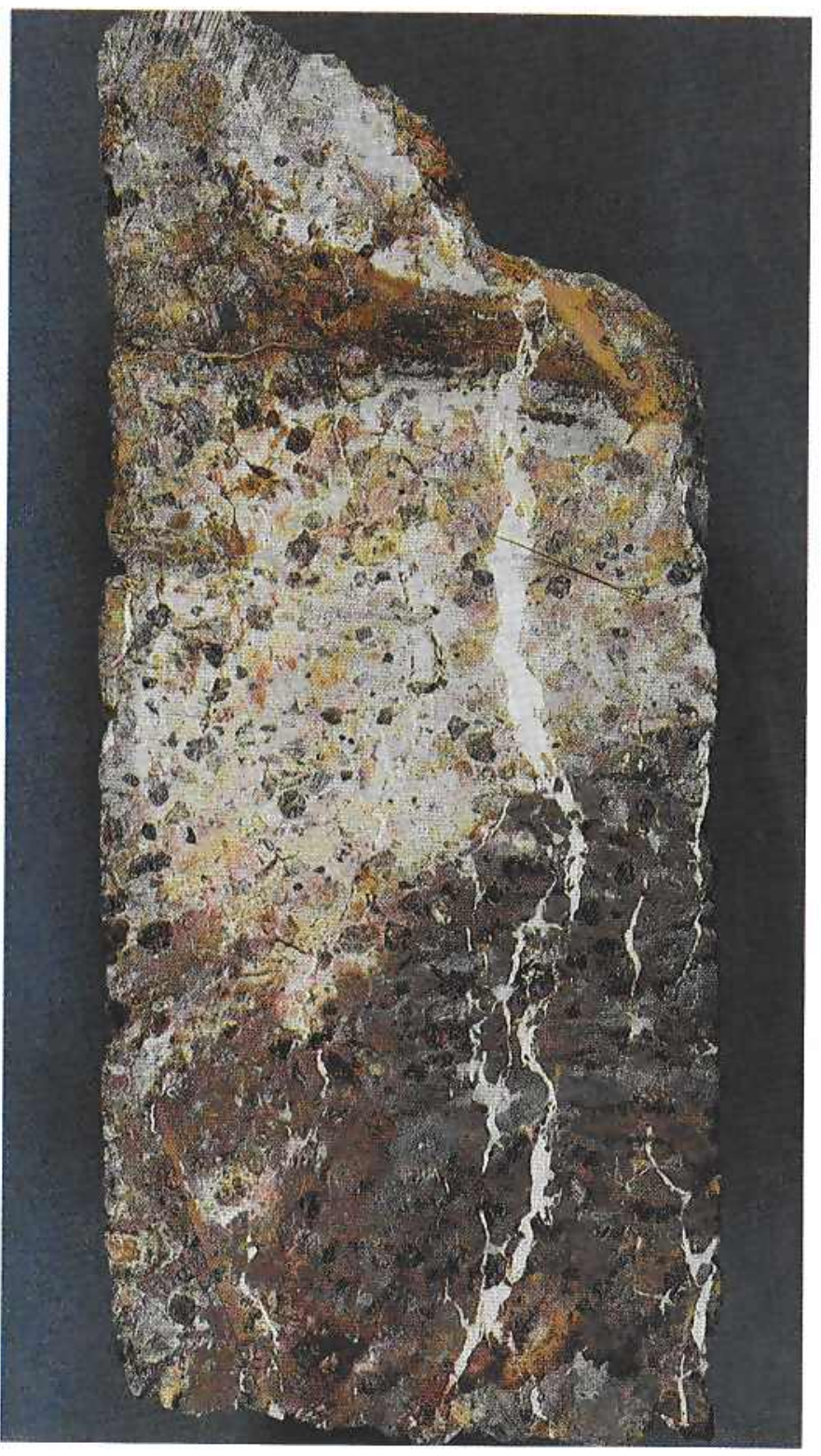

0 10 20 MILLIMETERS

FIGURE 66.-Drill core from $-92.7 \mathrm{~m}$ ( $-304 \mathrm{ft})$ in $\mathrm{Y}-12$ drill hole, showing three stages of hydrothermal alteration: (1) early Fe-oxide staining (brown), (2) bleaching (light tan), and (3) filling of late fractures with white kaolinite- $\alpha$-cristobalite-montmorillonite. Photograph by U.S. Geological Survey, 1984
Distribution of hydrothermal silica minerals in Y-12 is similar to that of Y-9. Early hydrothermal quartz is clear and euhedral and crystallized in vapor-phase cavities. In Y-12 this early quartz is increasingly conspicuous at deeper levels where earlier vapor-phase tridymite and $\alpha$-cristobalite from devitrified glass were destroyed, perhaps recrystallizing as hydrothermal quartz in cavities and thin partings in the tuff. Silica in the near-surface acid-altered zone is mostly clear to white $\alpha$-cristobalite, with later $\beta$-cristobalite and clear opal, and fills or coats fractures through leached tuff. Abundant $\alpha$-cristobalite exists as a white, fine-grained mixture with kaolinite in fractures to depths of $-52.8 \mathrm{~m}$. In the deeper parts of Y-12, the most abundant silica phase is chalcedony, which is present as dark-red cryptocrystalline fracture filling and includes abundant tiny red $\mathrm{Fe}$-oxide particles.

Calcite and fluorite are generally scarce late vein minerals below $-260.6 \mathrm{~m}$, although bladed calcite is locally moderately abundant. Fluorite is fine grained and identified only by X-ray diffraction.

The alteration minerals do not constitute a single homogeneous suite of a single stage of hydrothermal activity. Instead, multiple alternations of waters have occurred, differing in $\mathrm{pH}$ and oxidation state. A complex history is indicated; compare in figure 63, for example, the distribution patterns of pyrite (mostly reduced from goethite and hematite) and goethite (in part from oxidation of pyrite).

Permeability is low throughout most of Y-12, but significant breccia zones near $-60 \mathrm{~m}$ and $-175 \mathrm{~m}$ are largely but not completely self-sealed; flow is so dampened that the thermal gradients change in broad gradual curves close to but not on the reference boiling curve. Most minerals, with the probable exceptions of shallow alunite, opal, and $\beta$-cristobalite, are likely to be Pleistocene in age rather than post-Pleistocene.

\section{CHARACTERISTICS OF THE DRILL CORE FROM C-II}

The mineralogy of the core from C-II has been described extensively by Fenner (1936) and reinterpreted briefly by White (1955). The C-II core was reexamined during the present study for direct comparison with those from Y-9 and Y-12. The alteration in C-II is more like that in Y-12 than that in Y-9. Below the near-surface acid zone of C-II, where good core recovery began at $-17.7 \mathrm{~m}$, the rock characteristics alternate irregularly between bleached pyrite-montmorillonite-bearing tuff and Fe-stained (goethite) tuff (fig. 64). Locally in C-II, the tuff is bleached adjacent to fractures and grades rapidly outward within approximately $1 \mathrm{~cm}$ to gray Fe-stained tuff. Locally, also, partly bleached tuff with disseminated pyrite contains quartz and sanidine phenocrysts that have red Fe-oxidestained microfractures. In other places the reverse 
appéars; thin coatings of pyrite were deposited on microfractures in the groundmass and in phenocrysts, and then the pyrite was partly oxidized to goethite. Small amounts of marcasite, coexisting with pyrite, were identified at -31.4 and $-53.3 \mathrm{~m}$. Massive crusts of marcasite and pyrite have been identified as coexisting phases actively being deposited from mixed acid sulfate-chloride water at Echinus Geyser (see earlier subsection "Echinus Geyser").

Fracture patterns cannot be determined reliably for C-II because so little core was recovered or preserved. However, the filled fractures are mineralogically similar to those of Y-12, where bleached rocks have montmorillonite and pyrite as fracture fillings. Below $-66.4 \mathrm{~m}$ vertical fractures 1 to $2 \mathrm{~mm}$ wide are filled with dark-red-brown chalcedony with abundant tiny inclusions of red $\mathrm{Fe}$ oxides, again similar to Y-12.

Hydrothermal quartz is present below $-58.8 \mathrm{~m}$, where chalcedony in fractures also becomes abundant. The clear botryoidal opal and $\beta$-cristobalite in subhorizontal vaporphase cavities at -34.4 and $-42.7 \mathrm{~m}$ is somewhat anomalous. Clear to white botryoidal chalcedony and later deposited small clear euhedral quartz crystals occur in a cavity at $-67.4 \mathrm{~m}$. Fluid circulation patterns could have changed, or anomalous opal and $\beta$-cristobalite may even have been deposited during the final days of drilling when water near $215^{\circ} \mathrm{C}$ and containing $>1,000 \mathrm{ppm} \mathrm{SiO}_{2}$ was ascending the hole and rapidly boiling; the residual water could have been supersaturated with respect to quartz and chalcedony by 300 percent or more. At such high temperatures the more soluble silica minerals may convert rapidly to more stable (less soluble) silica minerals (fig. 4).

Mordenite is the only zeolite yet identified in the Norris Basin area. It is found with montmorillonite, quartz, and chalcedony at several places below $-67.4 \mathrm{~m}$ in C-II (fig. $64)$. Mordenite occurs as tiny white fibers in small cavities and open spaces along the edges of chalcedony-filled fractures; it appears to be codepositional or slightly later than silica phases.

The imperfect core recovery and unreliable temperature profile (White and others, 1975, p. 59-63) prevents any attempt to interpret the detailed history of hydrothermal activity in C-II other than to suspect its complexity-as in Y-12, indicated by alternation of bleached and Fe-oxidestained intervals.

\section{CONTROLS OF HYDROTHERMAL ALTERATION}

Alteration in Norris Geyser Basin is controlled largely by permeability of the Lava Creek Tuff, as well as by fluid compositions, temperatures, and relative stabilities of initial phenocrysts and groundmass minerals of the tuffs and the elapsed time available for each stage of alteration. We had hoped to recognize criteria that permitted correlation of alteration stages with the long, complex history of thermal activity in Norris Basin. No reliable criteria are yet evident, but tentative correlations are suggested in following sections of this report.

Primary textures affecting permeability during early stages of alteration are the open, elongate vapor-phase cavities and the compressed devitrified pumice fragments. Some of the groundmass is poorly welded and crystalline, thus, generally porous. Secondary textures affecting permeability are mainly fractures. Microfractures in phenocrysts and groundmass are abundant throughout the tuff. Therefore, oxidizing, Fe-staining fluids could readily permeate the porous groundmass. In the Fe-stained intervals, the microfractures either have red $\mathrm{Fe}$ stain or thin goethite or hematite coatings. Large throughgoing fractures are present throughout the drill cores; densely fractured intervals are shown by symbol for respective holes on figures 62,63 , and 64 . Major fractures are typically either steeply dipping to vertical, probably resulting from cooling joints in the tuff, or subhorizontal, parallel to eutaxitic foliation or flow banding. Width of fractures varies, and most are now filled with secondary minerals. Local textures suggest that sealing and refracturing took place along throughgoing fractures; for example, an early deposited filling will also have a later type of deposit, mainly clay and (or) silica, between wallrock and the earlier filling. Locally, later deposits cut across earlier fracture fillings. Only in the near-surface acid-leached tuff does later fracturing open a completely new channel rather than using a zone of weakness already established but sealed with secondary minerals. Selfsealing in highly fractured intervals is well developed in several sections of Y-12.

The groundmass of the Lava Creek Tuff was devitrified during emplacement and cooling to a fine-grained, locally cryptocrystalline, intergrown mixture largely of sanidine and $\alpha$-cristobalite. Thus, the tuff was not initially as hydrothermally unstable as a glassy tuff would have been.

Fluid composition and $\mathrm{pH}$ have directly affected the alteration mineralogy. The early stage of alteration by dilute oxidizing fluids produced Fe-oxide staining, $\mathrm{Fe}$ hydroxides, hematite, and magnetite. Subsequent deposition of chalcedony, quartz, and montmorillonite after the formation of $\mathrm{Fe}$ and $\mathrm{Mn}$ oxides may be related to an early hydrothermal event that was similar to the present circulating thermal waters of the near-neutral high $\mathrm{Cl}-\mathrm{SiO}_{2}$ type I (table 4).

The near-surface acid alteration resulted from leaching by low-pH acid $\mathrm{SO}_{4}$-Cl or acid-sulfate waters (types III and IV, table 4). Such waters presently form near the surface from oxidation of $\mathrm{H}_{2} \mathrm{~S}$ that concentrates in the steam phase above a boiling water table. In an earlier system, the steam condensed and mixed with more dilute meteoric waters (table 4), then circulated downward where perme- 
ability allowed access of fluids. Fe oxides of earlier alteration were leached, and kaolinite was deposited over smectite in cavities and fractures. These fluids must have been slightly reducing so that pyrite and pyrrhotite in the nearsurface bleached zone of Y-12 were deposited during this stage of alteration.

Temperature has had important effects on some of the alteration minerals, mainly the clay and silica minerals. Montmorillonite persists to the bottom of Y-9 at a measured temperature of $195.7^{\circ} \mathrm{C}$. In Y-12 montmorillonite occurs below the surficial acid-altered zone to a depth of $-196.6 \mathrm{~m}$, where the temperature was $198.6{ }^{\circ} \mathrm{C}$, and then rapidly changes to mixed-layer montmorillonite-illite over a vertical distance of $6 \mathrm{~m}$. The temperature at the bottom of Y-9, therefore, was not quite high enough to form the mixed-layer illite-montmorillonite, as in Y-12. The illite component of the mixed-layer clay in Y-12, relative to montmorillonite, becomes greater as depth and temperature increase. The illite component is about 95 percent of the mixture at the bottom of $\mathrm{Y}-12$, where the present temperature is $237.5^{\circ} \mathrm{C}$.

Several stages of silica minerals have crystallized in the Lava Creek Tuff, and locally the stage at which each crystallized is difficult to determine. Quartz phenocrysts and $\alpha$-cristobalite that formed in the groundmass during cooling devitrification of the glassy tuff are unequivocal. Granophyric quartz that formed in vapor-phase cavities during late cooling stages of the thick sequence of Lava Creek Tuff can usually be distinguished, with careful observation, from hydrothermal quartz, most of which is unequivocal as to origin. The $\alpha$-cristobalite in veins and cavity coatings is hydrothermal, but where it occurs in the groundmass in near-surface acid-altered tuff it cannot be differentiated from $\alpha$-cristobalite formed by devitrification during cooling of the tuff. The inference that hydrothermal $\alpha$-cristobalite exists in greater amounts in the leached near-surface tuffs is made on the basis of wholerock X-ray diffraction studies. Tridymite crystallized from the vapor phase during emplacement and initial cooling in cavities and pore spaces in the tuff; no evidence was found for any hydrothermal tridymite. Opal and $\beta$-cristobalite are always late, relatively shallow, hydrothermal deposits in the Norris drill holes. Quartz phenocrysts and granophyric quartz appear to be stable throughout. Tridymite and $\alpha$-cristobalite decrease in abundance with depth in Y-9 and Y-12, probably recrystallizing to hydrothermal quartz and chalcedony, which become more abundant with depth as an effect of fluid composition, increasing temperature, and hydrothermal alteration.

\section{SUMMARY OF HYDROTHERMAL ALTERATION}

The earliest stage of hydrothermal alteration affecting the tuffs of the Norris drill holes resulted in total leaching of plagioclase phenocrysts and replacement and leaching of mafic phenocrysts. Fe (and Mn in Y-9) was mobilized and deposited as oxides and hydroxides. Solutions invaded the tuff along subvertical and subhorizontal fractures, elongate subhorizontal vapor-phase cavities, and locally by hydrofracturing. Abundant silica and clay minerals (chalcedony and mixed-layer illite-montmorillonite in deeper parts but $\alpha$-cristobalite and montmorillonite in shallower levels) were deposited, often mixed with goethite. These minerals can result from reactions involving nearly neutral chloride- $\mathrm{SiO}_{2}$ waters, such as are presently active at depth.

Later bleaching solutions locally invaded the tuff, resulting in subhorizontal bleached intervals of several centimeters to tens of meters thick. Fe oxides and hydroxides were altered to pyrite, Fe-bearing montmorillonite, mixed-layer clays, and chlorite.

The alternation of dark reddish Fe-oxide-rich tuff with intervals of light-gray to white tuff in Y-12 and C-II are largely a result of the above two types of alteration. Locally, in Y-12 and C-II, at least one period of weak Fe-oxide deposition was superimposed upon the bleaching stage of alteration. These observations suggest that fluid compositions changed several times during the history of the hydrothermal system, perhaps in part related to icecovered glacial stages versus interglacial stages when atmospheric oxygen was more abundant. At present, neutral chloride-rich waters are mixing with acid-sulfate waters in the hydrothermal system, resulting in wide fluctuations of composition.

Near-surface acid alteration, as presently active, has resulted in strong bleaching of the surficial rocks, reaching the greatest depth below the surface in Y-12. This type of alteration has resulted in near-surface partial leaching of sanidine and deposition of hydrothermal kaolinite, $\alpha$-cristobalite, $\beta$-cristobalite, opal, and sulfides (pyrite, and locally pyrrhotite and stibnite). Near and at the surface, alunite and (locally sulfur in Y-12) has been deposited. Late fine-grained mixtures of kaolinite and silica ( $\alpha$-cristobalite, $\beta$-cristobalite, or opal, or all three) form thin fracture coatings in the near-surface bleached tuffs.

Present activity under the surface is probably continuing the self-sealing with silica and clay minerals, refracturing, and circulation of mixed waters. A model of fluid circulation is discussed later in this report.

\section{HEAT AND MASS FLOWS FROM NORRIS GEYSER BASIN}

\section{EARLY ESTIMATES}

Allen and Day (1935, p. 61) obtained nine sets of discharge measurements for Norris Basin from 1927 to 1932 by establishing weirs on Tantalus and Realgar 
Creeks near their outlets to Gibbon River (essentially draining the area shown on plate 1). These nine sets ranged in discharge from 1.35 to $4.35 \mathrm{ft}^{3} / \mathrm{s}$ or 38.2 to 123.2 $\mathrm{L} / \mathrm{s}$, utilizing a conversion factor of $1 \mathrm{ft}^{3} / \mathrm{s}=28.33 \mathrm{~L} / \mathrm{s}$. No chemical analyses were provided for the creek waters at different flow rates. For reasons not discussed by the original authors, the minimum value of $1.35 \mathrm{ft}^{3} / \mathrm{s}(38.25$ $\mathrm{L} / \mathrm{s}$ was "rounded" to $39 \mathrm{~L} / \mathrm{s}$ ) was utilized as their "reliable minimum" for calculating a convective heat flow of $3.12 \times 10^{6} \mathrm{cal} / \mathrm{s}$ above mean annual temperature (Allen and Day, 1935 , p. 135). All water was assumed to have discharged from springs and geysers at an average temperature of $85^{\circ} \mathrm{C}$, or $80^{\circ} \mathrm{C}$ above mean annual temperature. Heat contained in vapor or conducted from the ground surface was intentionally excluded as unmeasurable.

White (1957, p. 1642) increased Allen and Day's estimate to $8 \times 10^{6} \mathrm{cal} / \mathrm{s}$ by assuming that all water discharged from the basin had cooled by subsurface boiling, dilution, and thermal conduction from a temperature at least as high as the $205{ }^{\circ} \mathrm{C}$ measured by Fenner (1936) in Carnegie II drill hole. This assumption was obviously not precise because much of the Tantalus Creek discharge (utilized in both sets of early estimates) was derived from boiled upflowing water mixed with cold surface water in unknown proportions. These imprecise assumptions were considered by White (1957) to be more than offset by unmeasured conducted and convected heat (steam) from extensive areas that lacked discharging thermal liquid. Also, Allen and Day (1935, p. 61), in selecting $1.35 \mathrm{ft}^{3} / \mathrm{s}$ of discharge for their heat-flow calculations, probably should have assumed, instead, their average measured discharge of $\sim 3.3 \mathrm{ft}^{3} / \mathrm{s}$ as a more reliable base figure. No chemical data were supplied for the higher discharges, so equivalent chloride inventories, as presently utilized to calculate heat and mass flows, cannot be obtained from their data.

\section{CHLORIDE INVENTORIES OF GIBBON RIVER, 1966-67}

Fournier and others (1976) provided a new estimate of convective heat flow for Norris Basin by utilizing the chloride-inventory method of Ellis and Wilson (1955).

The method utilizes measured flow rates and chloride contents of permanent streams draining regions of thermal chloride activity, as well as chloride contents and temperatures of hot springs and research drill holes. The method requires a permanent stream or river to incorporate the thermal water and chloride at approximately their discharged rates. In homogeneous systems, utilizing chemical geothermometers and (or) deep well-water samples and physically measured temperatures, a unit of $\mathrm{Cl}$, such as $1 \mathrm{~g}$, can be calculated in terms of its equivalent associated heat at depth (Fournier and others, 1976), preferably prior to any boiling or conductive loss of heat.
Different base temperatures and relations to $\mathrm{Cl}$ can also be accommodated by mixing models. Thus, differing extents of near-surface dilution by waters of background or known $\mathrm{Cl}$ contents need not affect the calculated results of total convective heat or dissolved mass flows. The method can also be modified to account for thermal sources above the basin and, in favorable places, individual features of interest. Norris Basin is nearly ideal for the method if individual features are ignored, such as a major geyser eruption and local storage of $\mathrm{Cl}$ during dry periods as evaporites, increased surficial salinity, or as pore-water chloride retained temporarily in snowbanks and soil.

The chloride-inventory method is far superior to purely physical methods in simplicity, time required, and reproducibility under favorable conditions, because it depends on the conservative element $\mathrm{Cl}$ that permits correcting for heat involved in boiling, evaporation, and dilution. Under nonideal conditions the method commonly can be modified to attain special objectives or approximations.

The Yellowstone Park authorities requested that we avoid permanent weirs and other stream-gaging structures that might leave lasting evidence of our studies (such as the discharge channels and weirs illustrated by Allen and Day, 1935, p. 46). Furthermore, such structures generally require repair and unavoidable changes before each new measurement. Instead, sites of uniform stream. flow were selected by Fournier and others (1976) on the Gibbon River above and below the principal known flows from thermal sources in and adjacent to Norris Basin. The two primary gaging sites were on the Gibbon River at the Norris-Mammoth Bridge (near the Norris Ranger Station and Campground) and central Elk Park where the Gibbon River is closest to the former and present roads from Madison Junction to Mammoth and Canyon Village.

Calculations by Fournier and others (1976, p. 736) indicate that $\mathrm{Cl}$ was being added to the Gibbon River at an average rate of $95 \mathrm{~g} / \mathrm{s}$ during the six series of measurements in 1966-67, and that hot water carrying the dissolved $\mathrm{Cl}$ flowed into the Gibbon River at an average rate of $168 \mathrm{~kg} / \mathrm{s}$ (calculated for boiling from an assumed subsurface temperature of $270^{\circ} \mathrm{C}$ ). The equivalent convective heat flow was $46.7 \times 10^{6} \mathrm{cal} / \mathrm{s}$. Only one of the six sets

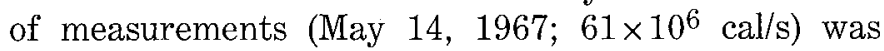
anomalous relative to the other five sets. This anomalous value can be explained by assuming a maximum runoff that includes snowmelt containing some stored pore water and salts.

A second set of calculations based on a different mixing model were also presented by Fournier and others (1976) that assumed the same total $\mathrm{Cl}$ flow but contained in deep $337{ }^{\circ} \mathrm{C}$ water discharging at a rate of $230 \mathrm{~kg} / \mathrm{s}$ and average heat flow of $85.5 \times 10^{6} \mathrm{cal} / \mathrm{s}$ prior to any boiling. The most reasonable model calculations fall between these two extremes. 
Allen and Day's (1935) heat-flow estimate of $3.12 \times 10^{6}$ $\mathrm{cal} / \mathrm{s}$ is clearly much too low, because major obvious sources of heat flow were ignored. White's (1957) revision to $8 \times 10^{6} \mathrm{cal} / \mathrm{s}$ of heat flow is a partial correction of defects but still seems much too conservative, being roughly only 15 percent of the lower of the two heat-flow estimates of Fournier and others (1976). Some other models that involve higher heat and mass flows than from Norris Basin alone are now indicated.

\section{ADDITIONAL DATA ON GL INFLOW TO THE UPPER GIBBON RIVER}

The two sets of 1976 heat-flow estimates discussed in the preceding section were designed specifically for the area of Norris Basin. However, several aerial photographs (especially figs. 5, 18, 19, 50, 67), Christiansen's (1975) map of the Norris Junction quadrangle, U.S. Geological Survey Map I-711 (1972), and unpublished maps north of Norris Basin by L.J.P. Muffler all show extensive areas of hydrothermal alteration (white in color aerial photographs) that contrast with the straw-colored, nonthermal, water-logged meadows.

These acid-altered areas are abundant along the NorrisMammoth Road, extending almost continuously from Norris Basin northward to Roaring Mountain. If other altered areas north and northwest of the basin are also included, the total area of extensive surface acid activity

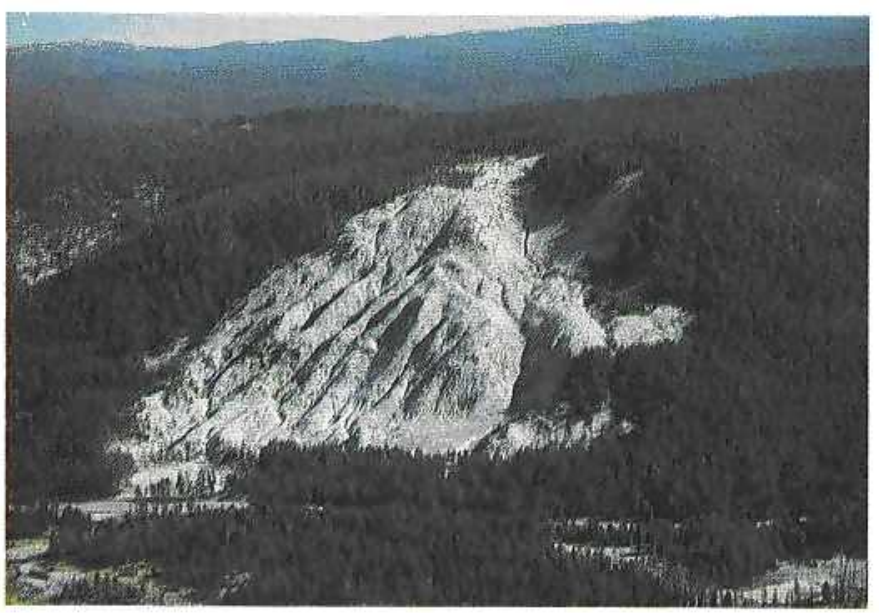

Figure 67.-Aerial photograph of Roaring Mountain near north end of a nearly continuous belt of acid leaching extending $\sim 10 \mathrm{~km}$ north of Norris Basin; subsurface may be the hottest (perhaps $>340^{\circ} \mathrm{C}$ ), most gas-rich part of a single large Norris-Roaring MountainMammoth system localized along the Norris-Mammoth Corridor (see fig. 68). Several areas on left and right sides and foreground are slightly more suitable for pine trees but are hot or acid enough to discourage other vegetation. Bleached area is $1 \mathrm{~km}$ wide. Photographed October $18,1967$. is roughly equal to the active parts of Norris Basin (pl. 1). The two main streams that drain these northern and western altered areas outside of the basin, respectively $1.3 \mathrm{~km}$ to the west and $1.5 \mathrm{~km}$ to the southwest of Norris Ranger Station (Christiansen, 1975), were sampled in October 1975 to test the possibility that major unseen $\mathrm{Cl}$ was discharging into the Gibbon River between the two prime gaging stations of Fournier and others (1976). Both 1975 water samples were acidic and much higher in $\mathrm{SO}_{4}$ than in $\mathrm{Cl}$ (only 6 and $35 \mathrm{mg} / \mathrm{L}$ ); their total mass discharge of $\mathrm{Cl}$ in visible drainage thus was only about $1 \mathrm{~g} / \mathrm{s}$ or $\sim 1$ percent of the 1976 estimate.

These streams could have been accompanied by much unseen local underflow in gravels below the upper of the two gaging stations as well as springs near river level on the north bank of the Gibbon River. One overlooked spring $\sim 50 \mathrm{~m}$ west of the Norris Ranger Station, for example, had a discharge near $10 \mathrm{~L} / \mathrm{s}$ and a $\mathrm{Cl}$ content of $166 \mathrm{ppm}$ when sampled by J.M. Thompson in 1981; its mass discharge of $\mathrm{Cl}$ was about $1.5 \mathrm{~g} / \mathrm{s}$. This suggests that much similar water could be flowing directly into the Gibbon River from other areas outside of the limits of the area shown on plate 1 .

To check on this possibility, J.M. Thompson, D.E. White, and R.A. Hutchinson traversed the Gibbon River on August 20,1984. The following observations by D.E. White are accompanied with analyses by J.M. Thompson:

$\mathrm{Cl}$ content of Gibbon River $(m g / L)$

Gibbon River at Campground Bridge (includes Solfatara Creek, the upper Gibbon River, and seepage from the Annex Area (pl. 1, D6).

Gibbon River above Realgar Creek (pl. 1, A4-NW; includes a few springs outside the area shown on plate 1 and seasonal seepage from block A6).

Gibbon River above Tantalus Creek inflow; this inflow (pl. 1, B1) is the major drainage from Norris Basin; its Cl content was $548 \mathrm{mg} / \mathrm{L}$, and flow rate, $\sim 10$ percent of the Gibbon.

Gibbon River 300 m below Tantalus Creek; sample collected in fractions across the Gibbon River, and from bottom to surface; net $\mathrm{Cl}$ increase of Gibbon $\sim 36 \mathrm{mg} / \mathrm{L}$ from Tantalus.

Gibbon River at Elk Park (Fournier lower sampling point, 1966-67).

For comparison, the average $\mathrm{Cl}$ content of the six 1966-67 samples from this Elk Park station was $54 \mathrm{mg} / \mathrm{L}$, which is nearly identical to our August 1984 sample. 
Although river flow rates were not measured in 1984, they are assumed to have been close to the 1966-67 average of $\sim 2,360 \mathrm{~L} / \mathrm{s}$, and the average $\mathrm{Cl}$ flow rate was $\sim 95 \mathrm{~g} / \mathrm{s}$. $\mathrm{Cl}$ contributed by Tantalus Creek on August 20, 1984, was approximately 67 percent of the Gibbon River total $(50.3-14.3) / 54)$. Thus, about 9 percent of the Gibbon's total $\mathrm{Cl}(4.7 / 54)$ was already present at the campground bridge, more may have existed as underflow, and visible hot springs adjacent to Norris Basin (pl. 1) may have contributed as much as 5 to 10 percent. We conclude that $\mathrm{Cl}$ discharged from the acid areas north and west of Norris Basin also contributed about 15 to 20 percent of the total, or approximately 15 grams of unseen $\mathrm{Cl}$ per second from acid areas along the Norris-Roaring Mountain belt.

Our 1984 Gibbon River data, although not as quantitative as desired, support the implicit assumption of Fournier and others (1976) that most $\mathrm{Cl}$ of the NorrisRoaring Mountain area is discharged in thermal water in and immediately adjacent to Norris Basin. Acid areas to the north and west evidently contribute some $\mathrm{Cl}$ not considered separately, and in lower proportions to their approximate areas and probable heat flows. Roaring Mountain (fig. 67) is an outstanding example of an area where much heat selectively escapes and generates acidleached areas that are not adequately represented as heat flow by locally discharged $\mathrm{Cl}$. Even here, for the Cl-inventory method to be strictly valid, a mixed area must be large enough to be representative of all fluids. Complete boiling of $\mathrm{H}_{2} \mathrm{O}$ accompanied by subsurface storage of $\mathrm{Cl}$ must be absent.

Norris Basin's estimated low heat flow of $\sim 47 \times 10^{6}$ $\mathrm{cal} / \mathrm{s}$ (Fournier and others, 1976), utilizing the Cl-inventory method and an initial assumed all-liquid temperature of $270{ }^{\circ} \mathrm{C}$, may be too low because much boiling, loss of vapor, and concentration of $\mathrm{Cl}$ have already occurred beneath various acid-leached areas. However, $270{ }^{\circ} \mathrm{C}$ is an attractive estimate of the liquid temperature directly below Norris Basin judging from thermal gradients in Y-9 and Y-12. With no overpressure, water at $270{ }^{\circ} \mathrm{C}$ should occur at a depth near $660 \mathrm{~m}$ (Haas, 1971, p. 942). An alternate estimate of $85 \times 10^{6} \mathrm{cal} / \mathrm{s}$ (Fournier and others, 1976) may be too high for Norris Basin alone because water boiling from $337^{\circ} \mathrm{C}$ is assumed directly under Norris Basin.

\section{HISTORY AND CONTINUITY OF HYDROTHERMAL ACTIVITY, NORRIS-MAMMOTH CORRIDOR}

The most complete record of hydrothermal activity within the Norris-Mammoth Corridor was obtained from Norris Basin and adjacent areas (see "Summary Settings of Norris Geyser Basin"). Extrusive rhyolitic volcanism closely associated with hydrothermal activity in the corridor ranges in age from about 400,000 years B.P. (Cougar Creek dome) to 80,000 years B.P. (Crystal Spring and
Gibbon River flows, table 1), but some older undated rhyolites also exist (Christiansen, in press). The oldest activity of Norris Basin consists of so-called roots of a hydrothermal system (pl. 1, C2), probably eroded by early Pinedale or older glaciers. Stream-abraded arkosic quartz sandstone contains small pebbles of earlier chalcedonic sinter cemented by hydrothermal chalcedony and nearly pure hydrothermal adularia. All nonsinter clastic debris was probably derived from the Yellowstone Tuff, and many plateau rhyolites were evidently not yet present, suggesting an age greater than 160,000 years B.P. (table 1). This oldest hydrothermal activity is probably greater than 200,000 years B.P., but we conservatively assume an age of at least 150,000 years B.P.

Activity has probably been continuous in Norris Basin throughout this $\sim 150,000$-year period from pre-early Pinedale glaciation to the present. As stated by White and others (1964), sinter terraces formed from subaerial discharge of boiling water supersaturated with respect to amorphous $\mathrm{SiO}_{2}$. True sinter does not deposit below ground surface or directly below water. Sinterlike banded silica minerals do form, commonly in near-vertical feeding fractures, but differ from sinter in their characteristic steep dips and common mirror images of their walls, depositing layer-by-layer inward. Some chalcedonic sinter may have crosscutting veins of similar mineralogy. A sinter-forming system overridden by ice ceases to deposit sinter at the former ground surface because of extensive meltwater dilution and absence of extensive evaporation. Previously formed older deposits are abraded; continuing discharge of hot water melts the ice, and its debris load is released and forced onward during advancing glacial stages when rates of ice advance are sufficiently high, as during the advancing stages of both early and late Pinedale glaciation. Early Pinedale kames were thick and saturated with meltwater, probably because of basin damming by the Gibbon River rhyolite flows ( 90,000 years B.P.). Convection of $\mathrm{SiO}_{2}$-rich thermal pore water in kames devitrified and cemented these obsidian-rich deposits, especially after early Pinedale ice started to stagnate and retreat.

A similar thermal release of glacial debris occurred during late Pinedale glaciation, which also formed kames around the south margin of Norris Basin. However, these kames, in general, were not cemented, either because glaciation was too short-lived or, more probably, because the Gibbon River lava dam had eroded, draining Norris Basin to the sediment floor, preventing convection of highsilica water through these younger kames. Late Pinedale kames and till are scarce in the central and eastern parts of Norris Basin (pl. 1), probably indicating rapid deglaciation:

Evidence of Pleistocene thermal activity is almost completely absent in the $25-\mathrm{km}$ stretch of the corridor between 
Apollinaris Spring and Terrace Mountain-Mammoth Hot Springs (Bargar, 1978). Old, horizontally bedded travertine mapped by Pierce (1973) as pre-Pinedale in age underlies early Pinedale glacial deposits of Terrace Mountain and part of the north wall of Yellowstone Canyon north of Gardiner. Cemented thermal kame deposits are scarce, but travertine deposits are abundant in parts of a crudely linear area about $20 \mathrm{~km}$ long and $5 \mathrm{~km}$ wide, elongate north-south approximately along the northern extension of the Norris-Mammoth Corridor. No mapped faults north of Gardiner were recognized that might have served as structural controls for these old travertines north of Terrace Mountain. Deposition of travertine may require subaerial discharge of springs high in calcium and bicarbonate, yielding carbonate that reacts with dissolved Ca to precipitate $\mathrm{CaCO}_{3}$ on loss in pressure and separation of $\mathrm{CO}_{2}$ to a vapor phase. This reaction seems more likely to occur in subaerial environments as compared to sublacustrine or subglacial discharge. However, the old travertine has one puzzling characteristic that differs from modern travertine. The older deposits have remarkably uniform horizontal bedding that lacks the terraced irregularities of modern subaerial travertine.

These older deposits could have formed in shallow icemarginal lacustrine environments during late recessional glacial stages. Regardless of this uncertainty, the long record of travertine deposition from Mammoth and related systems crudely correlates with that of sinter deposition in and near Norris Basin. Data from both localities, inadequately controlled by specific age, are interpreted as tentative support for the concept of continuous activity at roughly constant levels of intensity (probably within an order of magnitude in discharge rates) for perhaps 100,000 years, reasonably extended to a best guess of 150,000 years, but reliable data do not yet actually prove this.

Fossil travertine and sinter provide evidence for periods of subaerial activity within the total timespan, and kame deposits cemented by hydrothermal minerals provide evidence for at least partial thermal continuity during periods of glacial advance when meltwater debris was transported beyond the limits of intense thermal discharge. In spite of uncertainties, more data on hydrothermal continuity clearly are available from Yellowstone Park than from Steamboat Springs, Nevada, where the longest timespan of well-studied world systems ( $\sim 3$ million years; Silberman and others, 1979) has been identified.

The travertine deposits north and south of Gardiner may contain the longest and most nearly continous record of activity of all Yellowstone systems (Pierce, 1973, oral commun., 1985). Attempts were made (John Rosholt, U.S. Geological Survey, oral commun., 1966) to date travertine of Terrace Mountain, the oldest and highest near
Mammoth, by radioisotope disequilibrium methods. The oldest are near isotopic equilibrium and yield ages near 100,000 years B.P. The old travertine of Terrace Mountain, at $\sim 2,377 \mathrm{~m}$ altitude, projects across Golden Gate and Rustic Falls to a similar small travertine remnant on the southwest slope of Bunsen Peak at a basal altitude of $\sim 2,317 \mathrm{~m}$. Downcutting of at least $122 \mathrm{~m}$ at Rustic Falls and much greater downcutting between Terrace Mountain and the travertine north of Gardiner (Pierce, 1973; altitudes at least as high as 1,890 m) indicate entrenchment by the Yellowstone Canyon of $275 \mathrm{~m}$ or more since the Terrace Mountain travertine was deposited. All of these old travertine deposits have almost perfect horizontal bedding, suggesting deposition on a nearly horizontal land surface being entrenched by Yellowstone River and its tributaries.

The record of thermal activity of Norris Basin now seems best explained by a roughly constant (order of magnitude) level of thermal activity during and after Pinedale glaciation, and possibly earlier. No evidence has been found to support any large post-Pinedale variations in level of activity. Known changes are best explained as short-term oscillations related to self-sealing of channels followed by hydrofracturing, tectonic events, increased permeability, and discharge, even if only temporary. Some longer term changes surely have occurred, but we have no reason to suspect as much as an order-of-magnitude change in discharge in Norris Basin during the past 150,000 years. However, we also cannot prove that such changes are absent.

In other parts of the Norris-Mammoth Corridor, a scanty record of early activity has been preserved only near Roaring Mountain, where unaltered Obsidian Cliff rhyolite $(180,000$ years B.P.) overlies hydrothermally altered Lava Creek Tuff. Late(?) Pinedale hydrothermal explosion craters are well preserved on the northeast side of the mountain. Intense preglacial and postglacial hydrothermal acid leaching characterize the west face of the mountain, but sinter deposits are absent. A detailed history of activity is normally not preserved in such acid areas.

Concepts similar to those applied at Steamboat Springs, Nevada (White, 1968), for total heat and mass flow requirements have been applied to Yellowstone Park, with important modifications by Fournier and others (1976, p. 738-739) and equivalent assumptions. These authors concluded that hydrothermal convective heat losses from the park, assuming heat-flow rates similar to present rates for 150,000 years, would require $15,000 \mathrm{~km}^{3}$ of granitic magma cooled and crystallized from $900{ }^{\circ} \mathrm{C}$ to $500{ }^{\circ} \mathrm{C}$. The enlarged Norris Basin-Roaring Mountain segment of the corridor, utilizing the Gibbon River chloride inventory at Elk Park, has a present average convective heat flow of $0.85 \times 10^{8} \mathrm{cal} / \mathrm{s}$, or about 7 percent of present losses 
from the whole park. Seven percent of the magma requirement of the total park over 150,000 years is equivalent to $\sim 1,050 \mathrm{~km}^{3}$ of magma just for the NorrisRoaring Mountain part of the total magma system.

\section{A NEW MODEL FOR CONTINUOUS LONG-LIVED HYDROTHERMAL SYSTEMS}

Previous models for hydrothermal systems have generally assumed that required heat was supplied by the cooling and crystallizing of a batch (or batches) of granitic (or rhyolitic) magma. These calculations resulted in seemingly unreasonable demands if continuous activity is assumed at present rates of heat loss for the full assumed timespan. Indeed, the magma demand was so large that the Steamboat Springs estimate was arbitrarily cut to a more conservative 10 percent of the indicated timespan of 3 million years, but even this required $3,000 \mathrm{~km}^{3}$ of rhyolitic magma.

An alternate model for explaining huge heat losses required for long-lived hydrothermal systems is suggested here. Instead of assuming tremendous volumes of granitic or rhyolitic magma existing in the shallow crust at any one time, let us instead assume that superheated basaltic magma from the mantle convects up into the shallow crust and loses some heat by conduction and partial crustal melting as the basalt migrates up to a density-stratified interface of basalt overlain by a fractionated silicious cap. Low-solubility (vesiculated) $\mathrm{CO}_{2}$-rich vapor, $\mathrm{H}_{2} \mathrm{O}$, and other gases separate and migrate through the $\mathrm{SiO}_{2}$-rich fractionated cap of the magma chamber.

The above-described magma chamber is similar to previously proposed models for calderas and ash-flow tuffs with the important difference that convection is also assumed within the deep basaltic neck that connects the mantle and the silicic differentiated cap. The hottest $\mathrm{CO}_{2}$-saturated basalt presumably flows up near the center of the neck and becomes more buoyant as $\mathrm{CO}_{2}$ and other gases of limited solubility vesiculate the magma. The basalt also cools as it reacts and loses some heat to partly melt adjacent crustal rocks. Degassed and partly cooled basalt is higher in density than the hot rising vesiculated basalt, so cooled basalt completes a convective cycle by descending, merging, and mixing with a very large mixedphase mantle reservoir. A very long lived $\mathrm{CO}_{2}$-rich mantle hot spot would be especially favorable for supporting and maintaining very long lived volcanic-hydrothermal systems.

This model could supply heat and a new component of basalt continuously, or semicontinuously, thereby minimizing the crustal volume of crystallized magma required. The volume of silicic magma produced by each "pass" of basalt is not strictly defined by heat contents of the two magma types but, instead, is dependent upon the limiting physical characteristics of both magma types and the limits of new heat and new $\mathrm{CO}_{2}$ and other gases from the mantle basalt reservoir.

Recent geophysical studies of Yellowstone Park and the Snake River Plain (Smith and others, 1977; Iyer, 1979, 1984) indicate huge deficiencies in mass and in seismic velocity to depths of as great as $200 \mathrm{~km}$ below the surface, as well as low upper-mantle densities. Although geophysical data do not prove the convective-basalt model suggested here, the data are permissive for the Yellowstone volcanic-hydrothermal system as a whole. We are much less confident that this same model can apply to the smaller Norris-Mammoth subsystems supported here, but we are not aware of evidence disproving the possibility.

\section{THREE HYDROGEOLOGIC MODELS FOR PRESENT HYDROTHERMAL ACTIVITY IN THE NORRIS-MAMMOTH CORRIDOR}

Hydrothermal convection systems that could explain the activity of Norris Basin and other parts of the NorrisMammoth Corridor are considered in three categories: 1. Local sources of magma, heat, and convection exist under or near Norris Basin; presumably other major centers may exist elsewhere along the corridor but are not required. No one, to our knowledge, has specifically supported this model although early versions of this report favored it specifically for Norris Basin.

2. Magma, heat; and related hydrothermal convection exist at various places along the Norris-Mammoth Corridor, perhaps with major foci near the sources of the Gibbon River flow and the Roaring MountainObsidian Cliff flow, and minor foci elsewhere. This category, with many variants, is the most complex and attractive of the three, but a single "best" variant cannot yet be selected.

3. Norris Basin and other thermal areas of the corridor are all part of one huge integrated Yellowstone system, possibly confined strictly to the caldera until the past few hundred thousand years. This model has been supported or implied by many studies of Yellowstone's thermal systems, including those of White (1957), Fournier and others (1976), and Truesdell (1976). Problems for this model include: (a) Why is such a large complex system recharged from a single meteoric source (or homogenized from multiple sources) even though potential recharging structures are distributed around the caldera margin (U.S. Geological Survey, 1972)? (b) Local meteoric - dilution seems required in many places (detailed data not reviewed here). Why, then, are local deep recharges excluded? (c) Aligned fossil and active thermal discharges seem absent between the caldera 
ring-fracture zone and Norris Basin near the caldera rim (fig. 1), even though the model requires forced subsurface liquid flow over the buried caldera rim. Could shallow intervening rocks have been so impermeable and channels so highly pressured that no gas-rich fraction could separate and form acidaltered areas? (d) Acid areas are rare to the south of Norris Basin but are abundant to the north (see subsection "Chloride Inventories of Gibbon River, 1966-67'); this is not consistent with early loss of mobile vapor, as expected from northward flow of fluids from the caldera, presumably boiling at least in places, and with major discharge of low-gas liquid within the basin. (e) The age of the Norris hydrothermal system, 150,000 years B.P. or more, agrees reasonably well with the prominent rhyolitic volcanism in the corridor (table 1), although older undated rhyolites in the corridor may be present. Older postcaldera flows are likely to be completely concealed by younger flows within the caldera but are much less probable within the corridor, where young volcanic cover is so scanty. A very reasonable hypothesis assumes that corridor hydrothermal activity is completely dependent on corridor rhyolitic volcanism, which is the underlying assumption of category 2, now considered in greater detail.

Volcanic heat sources could be distributed along the corridor or could be focused in one or two parts of the corridor, as implied above: (1) a northern and probably slightly older system, perhaps centered near the Obsidian Cliff flow (age, 180,000 years B.P.) and Roaring Mountain, which could explain the fluid compositions between this center and Norris Basin as well as the more dilute Mammoth system, with its evidence for interaction with carbonate rocks; (2) a southern segment near the vent dome of the Gibbon River flow (90,000 years B.P.), probably younger than (1) above. Such a center could account for all activity in Gibbon Basin and near Gibbon Canyon, specifically including the thermal areas of Elk Park, Gibbon Hill, Paint Pots, Sylvan Springs, and Monument Basin, south and southwest of Norris, not adequately considered elsewhere in this report. A convective center in this area alone, or with a second center such as (1) above, best explains the ${ }^{3} \mathrm{He} /{ }^{4} \mathrm{He}$ ratio data of Kennedy and others (1985, fig. 12a), which demonstrate that the mantle-derived indicator, ${ }^{3} \mathrm{He}$, increases southward from Roaring Mountain to Norris to Beryl Spring. Beryl Spring has an exceptionally high ${ }^{3} \mathrm{He} /{ }^{4} \mathrm{He}$ ratio, being second only to the Mud Volcano system in Yellowstone Park (Kennedy and others, 1985, fig. 12a). Beryl Spring, along with several in Norris Basin, are among the highest in $\mathrm{Cl}$ content of all Yellowstone springs, but no comparable spring exists near Roaring Mountain and Obsidian Cliff. Of major consideration in interpreting helium isotope data are the ages of rocks traversed by each system, the extent of previous thermal release of stored crustal ${ }^{4} \mathrm{He}$ (from U-Th disintegration) and the relative concentration of diluting meteoric water, indicated qualitatively by $\mathrm{Cl}$ contents. To illustrate the complexities involved, an Obsidian Cliff system could still be so young that major crustal ${ }^{4} \mathrm{He}$ is still being released from previously unheated crustal rocks. In contrast, Beryl Spring is so close to the caldera boundary of Yellowstone's cycle 3 (and possibly cycle 1 ) that little stored crustal ${ }^{4} \mathrm{He}$ remains to be released.

Existence (or dominance) of a southern corridor hydrothermal center is generally favored by Wes Hildreth (oral commun., 1985), who first discovered the remarkable fact that all corridor rhyolites, including the Gibbon River flow, differ distinctly in $\delta^{18} \mathrm{O}$ from all caldera rhyolites (Hildreth and others, 1984). Corridor rhyolites are uniformly high in $\delta^{18} \mathrm{O}$, nearly identical to Yellowstone's first-cycle extrusive rhyolites prior to eruption of the Huckleberry Ridge ash flows of $\sim 2$ m.y.B.P. The phenomenal lowering of $\delta^{18} \mathrm{O}$ in extruded rhyolites immediately after the huge caldera collapses of cycles 1 and 3 by as much as 6 per mil of $\delta^{18} 0$ were followed by only partial recovery in the caldera; in contrast, all quartz of corridor rhyolites is near $\delta^{18} \mathrm{O}=7.5 \pm 1$ per mil, typical of unmodified continental rhyolites.

Wes Hildreth and R.L. Christiansen (written commun., 1985,1986 ) favor a separate corridor source for hydrothermal activity, as opposed to a caldera source, and also favor a southern corridor focus because of the magnitude of locally extruded rhyolite (principally the Gibbon River flow). This is also consistent with the available ${ }^{3} \mathrm{He} / 4 \mathrm{He}$ data of Kennedy and others (1985).

The present authors are impressed by evidence most simply explained by a southern corridor focus of volcanic activity, but such a focus does not, alone, adequately explain the distribution of spring compositions and acidaltered areas from Norris Basin northward to Mammoth. Tentatively, until more data are available, we favor a corridor model with two (or more) volcanic foci. Deep meteoric recharge of all corridor systems is probably supplied from the Gallatin Range west of the corridor.

\section{EXPLANATIONS FOR WIDESPREAD DISTURBANGES OF NORRIS THERMAL FEATURES AND INTIMATE ASSOCIATIONS OF DIFFERENT WATER TYPES}

Nearly contemporaneous changes in thermal features were discussed in the subsection "Widespread Contemporaneous Changes" and summarized in table 8. Affected features are all within a central north-striking belt through Back Basin and Porcelain Basin, the major named subdivisions of Norris Basin (pl. 1). All thermal water 
types are involved, most notably including the nearly neutral waters with highest $\mathrm{Cl}$ and $\mathrm{SiO}_{2}$ contents (table 4) that are absent in the adjoining eastern and western belts of Norris Basin.

Depending on which hydrogeologic model is favored as most probable for the deep aquifer of Norris Basin, a wide range of temperatures could characterize this aquifer from a minimum of $\sim 250 \mathrm{C}$ (slightly above the maximum temperature of $237^{\circ} \mathrm{C}$ measured in $\mathrm{Y}-12$ drill hole) to an overall maximum probably near $360^{\circ} \mathrm{C}$ (Truesdell and Fournier, 1976; Truesdell and others, 1978). Fournier and others $(1976)$ selected two deep temperatures, $270^{\circ} \mathrm{C}$ and $337^{\circ} \mathrm{C}$, to calculate alternate sets of deep flow data and total convective heat for Norris Basin.

One attractive hydrogeologic model for the NorrisMammoth Corridor is illustrated diagrammatically on figure 68. This figure assumes that $\sim 340{ }^{\circ} \mathrm{C}$ is a reasonable maximum temperature near the base of or below the Lava Creek Tuff near Roaring Mountain; comparable models can also be calculated for other assumed temperatures. During southward migration of a major fraction of this water to Norris Basin, $\mathrm{CO}_{2}$ and $\mathrm{H}_{2} \mathrm{~S}$, initially abundant, are concentrated in vapor bubbles that do not react with wallrocks. Any fractures or pockets in the upper part of the aquifer that have potential escape channels to the surface selectively permit escape of the low-density vapor phase, from which most chloride is excluded. Near the surface $\mathrm{H}_{2} \mathrm{~S}$ reacts with atmospheric $\mathrm{O}_{2}$, and dissolves in condensing steam and local meteoric water, thereby causing the acid bleaching of an almost continuous zone southward to Norris Basin. Most residual chloride water remains and cools in the subsurface to about $270{ }^{\circ} \mathrm{C}$ (fig. 68). Thus, neutral water high in $\mathrm{Cl}$ and $\mathrm{SiO}_{2}$ is the most representative fluid of the deep aquifer underlying Norris Basin and is largely discharged along the central belt of springs and geysers at relatively high rates (type I, table 4). Acid waters occur in two belts along the northwest and southeast margins of Norris Basin (fig. 69) and also occur with neutral waters in the central belt. A major Norris problem is to account for the nearly random association of water types in this central belt, and why the neutral waters, also highest in salinity and $\mathrm{SiO}_{2}$ but lowest in $\mathrm{SO}_{4}$, are absent from the marginal belts.

Our immediate objective here is to present a tentative diagrammatic model of Norris Basin that reasonably explains the differences in water types and constituent ratios, and why abrupt changes in chemistry and behavior occur so frequently in Norris Basin but are relatively rare elsewhere. The eastern and western of the three northtrending belts of waters are dominated by acid $\mathrm{Cl}-\mathrm{SO}_{4}$ types, are only moderate in salinity, and are rarely involved in the widespread disturbances listed in table 8.

Thus, the major problems of accounting for widespread changes in behavior and water types mainly concerns the central belt of neutral and mixed waters of Porcelain and Back Basins. Some springs of this central belt normally

S

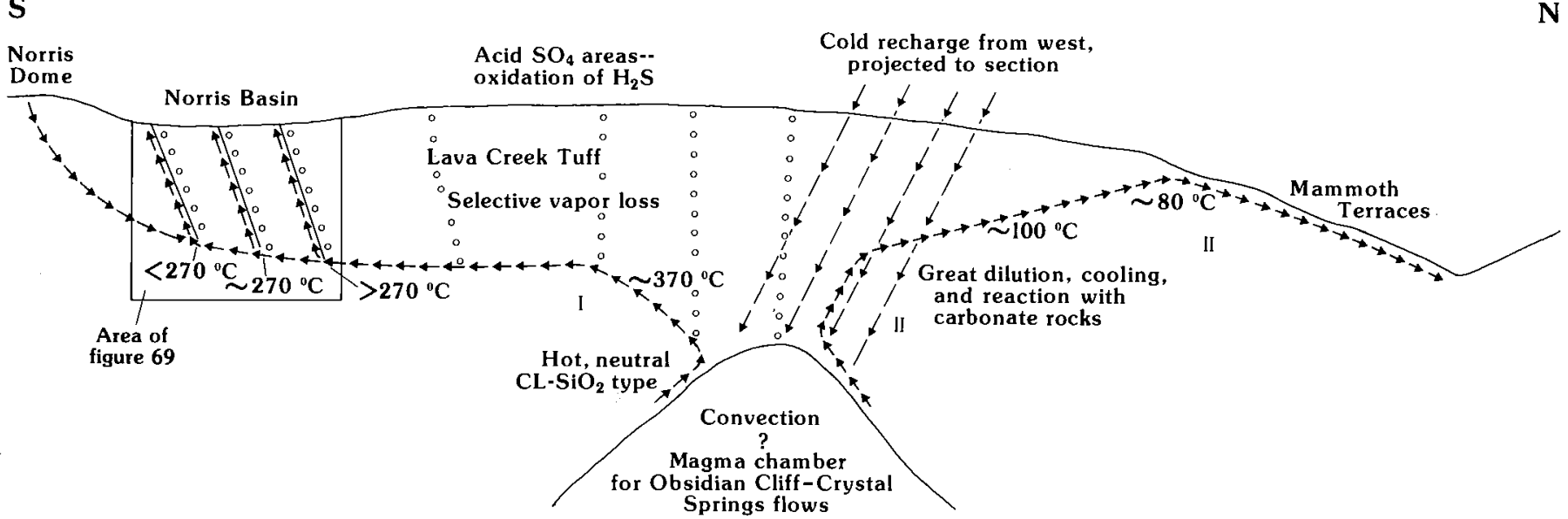

FIGURE 68.-Diagrammatic north-trending section along NorrisMammoth Corridor, one of several alternative models. Section assumes sources of volcanic heat and rare soluble elements from rhyolitic magma beneath the corridor; dominant meteoric water recharge is from northern Gallatin Range northwest of section. Hot saline upflow splits into two branches that differ greatly in temperature, salinity, and meteoric dilution: (I) Hot most saline southern branch boils and selectively loses pressure and gases as it flows upward and then southward, forming acid-altered areas by near-surface oxidation of steam-enriched $\mathrm{H}_{2} \mathrm{~S}$ and other gases acidified near surface by atmospheric $\mathrm{O}_{2}$; most residual chloride water discharges within and near Norris Basin. (II) Northern branch is extensively cooled and diluted by shallow meteoric water, also from Gallatin Range; this mixture reacts extensively with pre-Tertiary sedimentary rocks, dissolving carbonates and sulfate (from shales?); $\mathrm{CO}_{2}$ and other gases exsolve at shallow depth under Mammoth Hot Spring terraces. Interglacial hot springs deposited travertine on Terrace Mountain and north of Gardiner. 
do not evolve in water type, but most specific springs that have changed (tables 5, 8, and text) are within this belt. The low water-logged parts of Back and Porcelain Basins typically discharge acid $\mathrm{Cl}_{-} \mathrm{SO}_{4}$ springs and geysers. In contrast, the neutral $\mathrm{Cl}$ waters of the central belt are generally discharged at altitudes slightly above the nearest basin floor. An outstanding example is a small unnamed cluster of neutral springs (pl. 1, D5-NW) that deposits white sinter from opalescent water about $20 \mathrm{~m}$ above the nearly flat floor of Porcelain Basin immediately to the east, characterized by numerous acid $\mathrm{Cl}-\mathrm{SO}_{4}$ springs and geysers. The neutral $\mathrm{Cl}$ waters evidently tap a deeper overpressured source that has only a little sulfate but much $\mathrm{Cl}$ and $\mathrm{SiO}_{2}$.

Figure 69, and alternate models incorporating differing directions of deep flow (not illustrated), illustrates these differences. Deep neutral $\mathrm{Cl}$ water, perhaps previously boiled but not oxidized, rises and boils enroute to the surface, selectively concentrating the deep constituents of low volatility. At the surface the residual water mixes with condensate and previously discharged waters of all types, and also mixes with rain and snow. $\mathrm{H}_{2} \mathrm{~S}$ is oxidized to $\mathrm{SO}_{4}$, and the acid mixture is concentrated by atmospheric evaporation (but rarely to the salinities of the discharged neutral $\mathrm{Cl}$ waters). These phenomena are common in many hot-spring areas of the world, but the unusual feature of Norris Basin is the frequency and rapidity of change from one chemical type to another. We hypothesize recirculation of surface-acidified waters down to a partly self-sealed boundary layer of low permeability. The water below this boundary layer is overpressured and is high in $\mathrm{Cl}$ and $\mathrm{SiO}_{2}$ but low in $\mathrm{SO}_{4}$. Thermal

SE

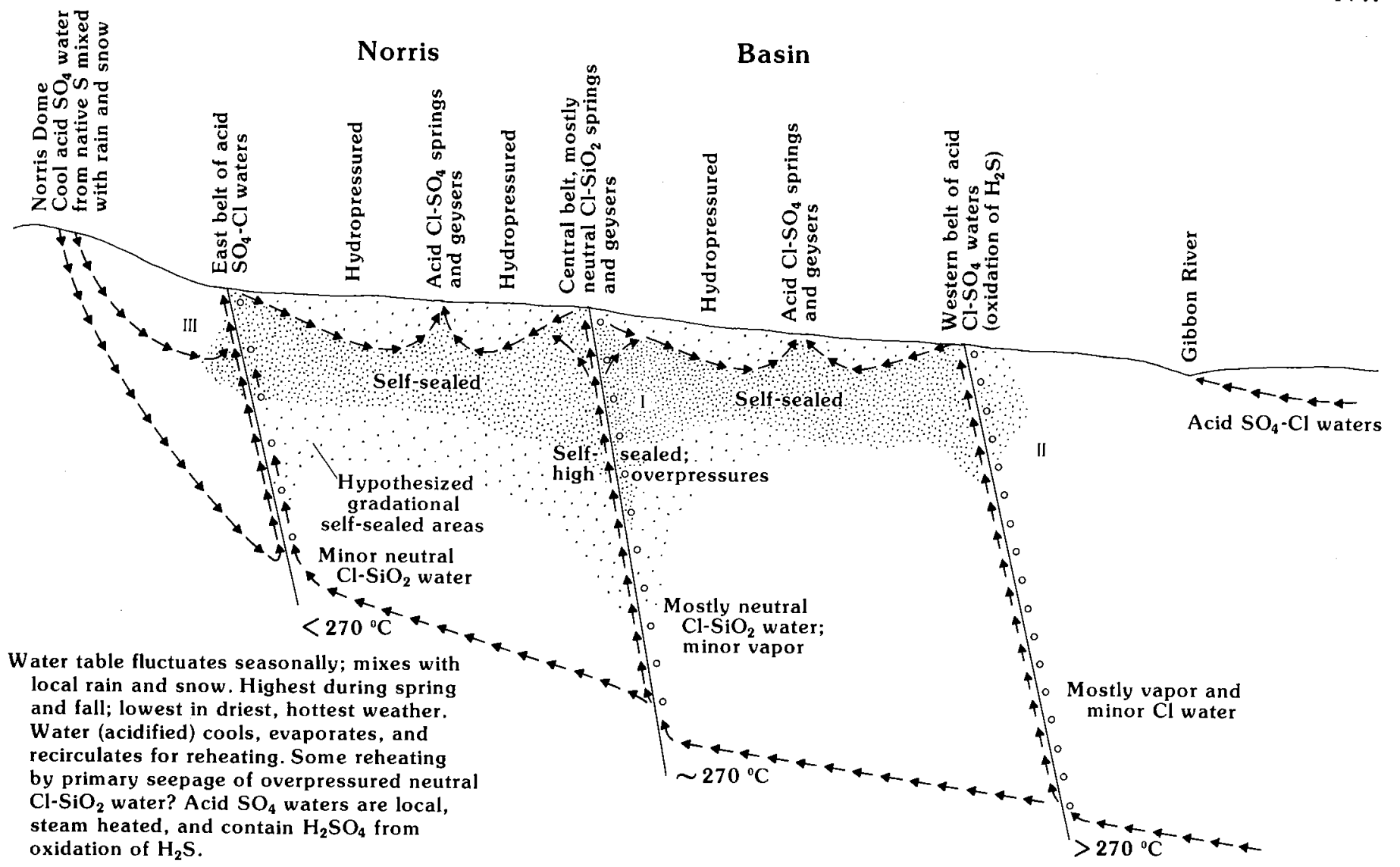

FIGURE 69.-Diagrammatic enlargement of Norris Geyser Basin, showing one model of circulation patterns that can explain distribution and evolution of principal water types. Neutral saline water from deep aquifer flows upward as springs and geysers within central belt (I) of Porcelain and Back Basins, overpressured and already depleted in most gases through boiling of exsolved gases. Acid $\mathrm{Cl}-\mathrm{SO}_{4}$ springs and geysers of this central belt are all diluted by surface rain, snow, and condensed steam; mixtures are acidified by oxidation of $\mathrm{H}_{2} \mathrm{~S}$ and are then recirculated and reheated within $\sim 100 \mathrm{~m}$ of the surface; some reheating may also occur from overpressured seepage of neutral $\mathrm{Cl}-\mathrm{SiO}_{2}$ water through the partially self-sealed zone. Western belt of springs (II) has dominantly acid $\mathrm{Cl}-\mathrm{SO}_{4}$ and minor acid- $\mathrm{SO}_{4}$ waters. Eastern belt (III) has acid $\mathrm{Cl}-\mathrm{SO}_{4}$ and acid-SO $\mathrm{SO}_{4}$ waters; some acid recharge may be related to Norris Dome. Drastic changes in water types, salinity, and $\mathrm{pH}$ are largely confined to belt $\mathrm{I}$. 
gradients are so high that the recirculating acid waters are reheated and even erupt as geysers. Depth of the selfsealed zone differs from place to place but is identifiable in most drill holes as the depth where near-surface hydrostatically pressured water increases in pressure downward to become overpressured water that rises above the self-sealed zone and even above the local ground level. Because self-sealing seldom if ever results in complete sealing, upward seepage of overpressured water into the overlying hydropressured recirculating water no doubt normally occurs through rocks (or sediments) of diminished permeability, as described by Keith and others (1978) in two Upper Geyser Basin drill holes. Such upward seepage of very hot water helps to account, along with extra conducted heat, for the high temperatures and abundance of acid geysers in Norris Basin. Another important factor, not previously emphasized, is the very low content of bicarbonate in all Norris waters. Probably because temperatures are so high, most $\mathrm{CO}_{2}$ is concentrated in vapor bubbles and not in solution and is therefore not available to react with silicate minerals. Thus, the neutral waters have little buffering capacity to resist acidification.

Why are physical and chemical changes so characteristic of Norris Basin and so commonly associated with widespread disturbances (table 8)? These abundant changes are also very likely to be related to the very high subsurface temperatures of the main feeding aquifer (at least $270{ }^{\circ} \mathrm{C}$ ) and high $\mathrm{SiO}_{2}$ contents (at least $600 \mathrm{ppm}$ at such temperatures), especially if much boiling and loss of $\mathrm{CO}_{2}$ has already occurred "upstream," as hypothesized in fig. 68. Silica content has increased rapidly as boiling and residual concentration have occurred, while quartz and the less soluble silica minerals have precipitated. Initial precipitation of one or more of these silica minerals is increasingly probable near and below $200{ }^{\circ} \mathrm{C}$, where the reference boiling curve bends rapidly toward $95{ }^{\circ} \mathrm{C}$ (upward in figs. 4, 62, 63; Fournier, 1973). Flow channels are filled with these silica minerals and overpressures consequently increase beneath the constricting self-sealed zones. Eventually, overpressure becomes great enough for abrupt hydrofracturing to occur.

To this point, the system behaves as we might have predicted. Hydrofracturing at the weakest point along a highly overpressured fracture tends to extend rapidly along the fracture in a chain reaction that soon affects adjacent springs of the same zone. The fracture widens as most surface vents increase in discharge or erupt as geysers as larger volumes of fluid (water plus vapor) become available. But why do these chain-reaction disturbances seem to be seasonally controlled, at least in recent years (table 8) favoring the drier months of July and August?

At such times, water levels, near-surface ground saturation, and dilution by cold low-silica surface waters are all near their seasonal lows, and $\mathrm{SiO}_{2}$ contents, supersaturation with respect to the silica minerals, and depositional rates are highest. All of these factors increase the rate of self-sealing and buildup of overpressure. In contrast, when water is most abundant and the basins are filled with water and melting snow, near-surface layers have higher thermal conductivity and newly discharged water is least boiled, $\mathrm{SiO}_{2}$ contents of ponded water and impedance by gas bubbles are lowest, rates of $\mathrm{SiO}_{2}$ deposition from recirculated acid waters are also at their seasonal lows, and hydrofracturing from increasing overpressures are least likely to occur. As a consequence of these factors all working together, the triggering by hydrofracturing most generally occurs during the drier summer months, consistent with the records of table 8.

Iyer and Hitchcock (1974) identified Norris Basin as a major source of seismic noise in Yellowstone Park, but no detailed study has yet been made of possible seasonal changes utilizing closely spaced sensitive seismographs to determine if the so-called noise includes some stronger events identifiable by location and depth that might cause hydrofracturing and seasonal concentrations of such events. We suspect that the seismic noise of hightemperature thermal areas is related to several different factors; detailed study could provide valuable evidence on changing activity, not yet utilized.

Detailed measurements at Steamboat Springs, Nevada (White, 1968, p. C33-C35), identified slight seasonal changes in temperatures, discharge rates, and $\mathrm{SiO}_{2}$ contents consistent with our Norris findings. However, seasonal changes at Steamboat Springs are not extensive because ponding and recirculation of water are slight, relative to Norris Basin.

\section{CONGLUSIONS}

Norris Geyser Basin has valid claims to being the most spectacular and diverse hydrothermal area in the United States and probably in the world. Most hydrothermal areas change with time, but adequate records are generally not maintained to substantiate the frequency, nature, and interrelations of such changes. Its nearest documented competitor in the world is probably the Rotomahana-Waimangu volcanic-hydrothermal belt of New Zealand's North Island (numerous New Zealand studies).

Changes occur frequently in Norris Basin; some are gradual and others are abrupt, most commonly involving multiple aligned vents. Records from Norris are more complete than for any other Yellowstone area because Park' Service naturalists, especially those who became fascinated by Norris's continuing changes, have observed and kept daily to weekly records over most normal tourist seasons, generally extending from June through Septem- 
ber. Sporadic records made by other Park Service employees and tourists have been preserved, but preservation of such records is largely left to chance. In the Upper Geyser Basin of the Firehole River, written records for all months are relatively complete for major geysers, but little official attention has been given to other springs and small geysers. The outstanding exceptions are due to the individual interest and high motivation of Marler (1973) and R.A. Hutchinson (Yellowstone informal records, commonly as annual summaries).

Norris Basin is near the intersections of three major structures (fig. 1), the north wall of the Yellowstone caldera, the Norris-Mammoth Corridor (with the frontal fault of the Grand Tetons as a possible southern extension), and the Hebgen Lake fault to the west (which may terminate the Gallatin Range at its subsurface southern downdropped end).

The Norris-Mammoth Corridor probably formed as a major downwarp or downfaulted sag in the caldera's rim during eruption of the third-cycle Lava Creek tuffs. This downdropped zone helped to preserve and protect more than $350 \mathrm{~m}$ of ash-flow tuff (perhaps much more at unexplored depths, with some also eroded from the top). This thick thermal blanket has been a major factor in the thermal evolution of Norris Basin. Chemical geothermometers indicate that an $\sim 270{ }^{\circ} \mathrm{C}$ aquifer at the base of the tuff is reasonable, and temperatures as high as 330 to $>360$ ${ }^{\circ} \mathrm{C}$ are permissible. Assuming the $270{ }^{\circ} \mathrm{C}$ temperature, the nearly linear temperature gradients in the lower parts of research drill holes Y-9 and Y-12 suggest that a major aquifer may exist near the base of the Lava Creek ashflow tuff, probably at least $0.5 \mathrm{~km}$ below present ground levels. Other major aquifers are unlikely to exist within these tuffs at intermediate depths.

Direct upflow of water supersaturated with respect to quartz at these high temperatures probably helps to explain the most unusual features of Norris Basin-its two major geysers (Steamboat and Monarch), and its high fluid contents of $\mathrm{SiO}_{2}$ relative to the solubility of the silica minerals (fig. 4; Fournier, 1973). Flow channels are continuously filling with silica and other minerals, but thermoartesian pressures from its recharging water, perhaps from the high Gallatin Range to the northwest, are so great that hydrofracturing periodically reopens old filled channels and creates new channels. Evidence of widespread, usually annual, disturbances (table 8 ) in Norris Basin are tentatively related to a north-striking central belt of mixed neutral and acid waters available for recirculation and reheating at relatively shallow depths. Such phenomena might explain the seasonal distribution of widespread disturbances that most commonly occur in the months of August and September, when rainfall and water levels are lowest. Seasonal hydrofracturing may also help to understand the abundant refracturing and fill- ing of quartz veins and veinlets of epithermal gold-silver deposits, usually assumed to be entirely tectonic. The basin's location on three major structural features, all tectonically active, provides additional reasons for the continuing changes.

Norris Basin is probably only a part of a larger system that extends northward at least $10 \mathrm{~km}$ to Roaring Mountain and Obsidian Cliff and southward to Beryl Spring, largely under the same confining thermal blanket. Many patches of acid-leached ground exist, mostly north of Norris Basin; Roaring Mountain is the most notable. This area and most other thermal areas along the belt discharge gases and meager acid-sulfate spring waters; chloride waters are scarce at the surface, but chloride inventories of the Gibbon River above and below Norris Basin suggest that a significant part of all $\mathrm{Cl}$ is contributed by sources near but outside of the immediate limits of Norris Basin. At least one other large volcanic center, not considered in detail, probably also exists in the corridor associated with the Gibbon River rhyolite flow and Beryl Spring southwest of Norris. The base temperature of water beneath Norris Basin is probably close to $270^{\circ} \mathrm{C}$, but an enlarged Norris Basin-Roaring Mountain system and (or) a Norris-Gibbon River system may have base temperatures near or above $330{ }^{\circ} \mathrm{C}$, consistent with Yellowstone's geochemical and mixing-model temperatures (Fournier and others, 1976; Truesdell, 1976). A thick massive cap of interlocking blocks of Lava Creek Tuff may permit continuous boiling and escape of separated gases during southward flow to Norris Basin, but the high volume of exsolving gases may exclude the entry of denser chloride water from steeply dipping channels. With largely horizontal flow of water but with gases already largely exsolved, vapor tends to fill openings at the top of the aquifer and selectively discharge through steeply dipping escape channels that serve as collectors, ordinarily excluding most of the dense residual Cl-bearing water. $\mathrm{CO}_{2}, \mathrm{H}_{2} \mathrm{~S}$, and $\mathrm{H}_{2} \mathrm{O}$ are the dominant gases; $\mathrm{H}_{2} \mathrm{~S}$ oxidizes near the surface to $\mathrm{S}$ and eventually to $\mathrm{H}_{2} \mathrm{SO}_{4}$, thus accounting for the acid-leached areas with little or no Cl-bearing springs.

Hydrothermal activity is unlikely to have been abundant in the Norris-Mammoth Corridor until long after the last caldera collapse and eruption of the Lava Creek Tuff. The earliest evidence for entry of new silicic magma into the corridor is offered by the Cougar Creek and Willow Park rhyolite domes, extruded about 400,000 and 320,000 years ago (table 1), respectively. Older rhyolites may exist elsewhere in the corridor (R.L. Christiansen, oral commun., 1986), but none has been dated. The major periods of rhyolite accumulation and eruption in the corridor occurred $\sim 400,000$ to 80,000 years ago (table 1 ), probably supplying the heat for the hydrothermal systems of Norris, Elk Park, Gibbon Meadows, Beryl Spring, and 
Monument Basin, where much evidence has been eroded or concealed, and glacial erratics of chalcedonic sinter are the most widespread evidence. The largest area of old sinter, now inactive and only partly preserved, is in southwestern Elk Park about $5 \mathrm{~km}$ southwest of Norris. The roots of an old Norris Basin system exist, with inconclusive evidence for still older activity preserved near the west rim of Norris Basin (pl. 1, C2). Present and recent activity, including Roaring Mountain, probably derive their heat and rare dissolved constituents from magma bodies recently chilled or still present at depth in the Norris-Mammoth Corridor.

A general model for explaining continuing, very longlived hydrothermal systems in large magma systems is presented for Steamboat Springs, Nevada, for the Yellowstone caldera activity near Yellowstone Falls, and possibly for the Norris-Roaring Mountain system (probably greater than 150,000 years old). Duration of continuous activity at Steamboat Springs, Nevada (about 3 million years; Silberman and others, 1979) had seemed far too long, so intermittent activity has previously been favored. This new model, consistent with recent deep geophysical data for the Yellowstone caldera as a whole, assumes that a high-level fractionating silicic magma chamber has a deep basaltic root extending far into the mantle (from seismic data, at least $200 \mathrm{~km}$ of total depth; Iyer, 1979). Basalt convects within the deep crustal interconnection, probably flowing up the central portion because of its high temperature and high content of buoyant $\mathrm{CO}_{2}$, already partly exsolved. The vapor phase vesiculates and expands upward, while somewhat cooled, gas-poor dense basalt convects down, presumably still hot enough to selectively melt a silicic fraction of the deep crust. The $\mathrm{CO}_{2}$-rich vapor fraction rises through an enlarging silicic cap until, with $\mathrm{H}_{2} \mathrm{O}$ from the mantle or from metamorphic dehydration reactions in the crust, total vapor pressure finally exceeds external pressure, producing ash-flow tuff eruptions and caldera collapse.

Downward-convecting slightly cooled basalt somewhat lower in $\mathrm{CO}_{2}$ is heavier than upflowing basalt (some recycled, some primitive) from the huge mantle reservoir, perhaps maintained by a long-lived mantle hot spot. The downflowing cooled basalt sinks deep into the huge mantle reservoir, mixing with hotter $\mathrm{CO}_{2}$-rich basalt; the hot mixture, partly renewed in $\mathrm{CO}_{2}$, then convects upward, perhaps maintining the volcanic-hydrothermal system for millions of years. Meteoric water supplies much of the shallow water of the system, perhaps convecting to depths of 5 to $10 \mathrm{~km}$. Metamorphic water, generally ignored in volcanic processes, is inevitably an important constituent from metamorphic dehydration reactions that characterize most rocks (and nearly all sedimentary rocks) of increasing metamorphic grade as temperatures increase to $600{ }^{\circ} \mathrm{C}$ and more. Whether such a two-way convection system can be established in relatively small shallow volcanic systems such as those proposed for the NorrisMammoth Corridor may seem doubtful but cannot be excluded by available evidence.

\section{SELECTED REFERENCES}

Abiko, Tsutomu, 1971, Recent hydrothermal activity at Noboribetsu, Hokkaido, Japan: Muroran Kogyo Daiga Ku Kenkyu Hokoku, Muroran, v. 7 , no. 2 , p. $453-460$.

Allen, E.T., and Day, A.L., 1935, Hot springs of the Yellowstone National Park: Carnegie Institution of Washington Publication 466, $525 \mathrm{p}$.

Bargar, K.E., 1978, Geology and thermal history of Mammoth Hot Springs, Yellowstone National Park, Wyoming: U.S. Geological Survey Bulletin 1444, $55 \mathrm{p}$.

Beeson, M.H., and Bargar, K.E., 1984, Major and trace element analyses of drill cores from thermal areas in Yellowstone National Park, Wyoming: U.S. Geological Survey Open-File Report 84-373, 40 p.

Brock, T.D., Brock, K.M., Belly, R.T., and Weiss, R.L., 1972, Sulfolobus: A new genus of sulfur-oxidizing bacteria living at low $\mathrm{pH}$ and high temperature: Archiv fuer Mikrobiologie, v. 84, p. 54-68.

Brock, T.D., and Mosser, J.L., 1975, Rate of sulfuric-acid production in Yellowstone National Park: Geological Society of America Bulletin, v. 86, p. 194-198.

Browne, P.R.L., 1971, Mineralisation in the Broadlands geothermal field, Taupo Volcanic Zone, New Zealand: Society of Mining Geology, Japan, Special Issue 2, p. 64-75.

Christiansen, R.L., 1975, Geologic map of the Norris Junction quadrangle, Yellowstone National Park, Wyoming: U.S. Geological Survey Geologic Quadrangle Map GQ-1193, scale 1:62,500.

1979, Cooling units and composite sheets in relation to caldera structure, in Chapin, C.E., and Elston, W.E., eds., Ash-flow tuffs: Geological Society of America Special Paper 180, p. 29-42.

1982, Late Cenozoic volcanism of the Island Park area, eastern Idaho, in Bonnichsen, Bill, and Breckenridge, R.M., eds., Cenozoic geology of Idaho: Idaho Bureau of Mines and Geology Bulletin 26, p. 345-368.

1984, Yellowstone magmatic evolution: Its bearing on understanding large-volume explosive volcanism, in Explosive volcanism: Inception, evolution, and hazards: Washington, National Academy of Sciences, p. 84-95.

(in press), The Quaternary and Pliocene Yellowstone Plateau volcanic field of Wyoming, Idaho, and Montana: U.S. Geological Survey Professional Paper 729-G.

Christiansen, R.L., and Blank, H.R., Jr., 1974, Geologic map of the Madison Junction quadrangle, Yellowstone National Park, Wyoming: U.S. Geological Survey Geologic Quadrangle Map GQ-1191, scale $1: 62,500$.

Eaton, G.P., Christiansen, R.L., Iyer, H.M., Pitt, A.M., Mabey, D.R., Blank, H.R., Jr., Zietz, Isidore, and Gettings, M.E., 1975, Magma beneath Yellowstone National Park: Science, v. 188, p. 787-796.

Ellis, A.J., and Wilson, S.H., 1955, The heat from the Wairakei-Taupo thermal region calculated from the chloride output: New Zealand Journal of Science and Technology, sec. B, v. 36, p. 622-631.

1961: Hot spring areas with acid-sulfate-chloride waters: Nature, v. 191 , p. $696-697$.

Fenner, C.N., 1936, Bore-hole investigations in Yellowstone Park: Journal of Geology, v. 44, no. 2, pt. II, p. 225-315.

Fournier, R.O., 1966, Estimation of underground temperatures from the silica content of water from hot springs and wet steam wells: American Journal of Science, v. 264, p. 685-697.

1973, Silica in thermal waters: Laboratory and field investigations, in Ingerson, Earl, ed., Symposium on hydrogeochemistry and 
biogeochemistry, Tokyo, 1970, Proceedings, Volume IHydrogeochemistry: Washington, D.C., The Clarke Company, p. $122-139$.

Fournier, R.O., and Rowe, J.J., 1962, The solubility of cristobalite along the three-phase eurve, gas plus liquid plus cristobalite: American Mineralogist, v. 47 , p. 897-902.

1966, Estimation of underground temperatures from the silica content of water from hot springs and wet steam wells: American Journal of Science, vol. 264, p. 685-697.

Fournier, R.O., and Truesdell, A.H., 1970, Chemical indicators of subsurface temperature applied to hot spring waters of Yellowstone National Park, Wyoming, in United Nations Symposium on the Development and Utilization of Geothermal Resources, Pisa, 1970: Geothermics Special Issue 2, v. 2, pt. 1, p. 529-535.

Fournier, R.O., White, D.E., and Truesdell, A.H., 1976, Convective heat flow in Yellowstone National Park, in United Nations Symposium on the Development and Use of Geothermal Resources, San Francisco, 1975, Proceedings, Volume 1: Washington, D.C., U.S. Government Printing Office, p. 731-739.

Haas, J.L., Jr., 1971, The effect of salinity on the maximum thermal gradient of a hydrothermal system at hydrostatic pressure: Economic Geology, v. 66, p. 942.

Hague, Arnold, 1887, Notes on the deposit of scorodite from arsenical waters in the Yellowstone National Park: American Journal of Science, ser. 3, v. 34, p. 171-175.

Hague, Arnold, and others, 1904, Atlas to accompany monograph 32 on the geology of the Yellowstone National Park; Norris Geyser Basin, geology sheet XXI [map]; U.S. Geological Survey.

Hein, J.R., Scholl, D.W., Barron, J.A., Jones, M.G., and Miller, Jacquelyn, 1978, Diagenesis of late Cenozoic diatomaceous deposits and formations of the bottom simulation reflector in the southern Bering Sea: Sedimentology, v. 25, p. 155-181.

Hemley, J.J., 1959, Some mineralogical equilibria in the system $\mathrm{K}_{2} \mathrm{O}$ $\mathrm{Al}_{2} \mathrm{O}_{3}-\mathrm{SiO}_{2}-\mathrm{H}_{2} \mathrm{O}$ : American Journal of Science, v. 257, no. 4, p. 241-270.

Hildreth, Wes, Christiansen, R.L., O'Neil, J.R., 1984, Catastrophic isotopic modification of rhyolitic magma at times of caldera subsidence, Yellowstone Plateau volcanic field: Journal of Geophysical Research, v. 89, p. 8339-8369.

Hitchen, C.S., 1935, A method for experimental investigation by hydrothermal solutions, with notes on its application to the solubility of silica: Transactions of the Institution of Mining and Metallurge, v. 44, p. $255-280$.

Honda, Sakuro, and Muffler, L.J.P., 1970, Hydrothermal alteration in core from research drill hole Y-1, Upper Geyser Basin, Yellowstone National Park, Wyoming: American Mineralogist, v. 55, p. 1714-1737.

Iyer, H.M., 1979, Deep structure under Yellowstone National Park, U.S.A.: A continental "hot spot": Tectonophysics, v. 56, p. 165-197. 1984, A review of crust and upper mantle structure studies of the Snake River Plain-Yellowstone volcanic system: A major lithospheric anomaly in the western U.S.A.: Tectonophysics, v. 105, p. 291-308.

Iyer, H.M., and Hitcheock, Tim, 1974, Seismic noise measurements in Yellowstone National Park: Geophysics, v. 39, p. 389-400.

Keith, T.E.C., and Muffler, L.J.P., 1978, Minerals produced during cooling and hydrothermal alteration of ash flow tuff from Yellowstone drill hole Y-5: Journal of Volcanology and Geothermal Research, v. 3, p. 373-402.

Keith, T.E.C., White, D.E., and Beeson, M.H., 1978, Hydrothermal alteration and self-sealing in Y-7 and Y-8 drill holes in northern part of Upper Geyser Basin, Yellowstone National Park, Wyoming: U.S. Geological Survey Professional Paper 1054-A, 26 p.

Kennedy, B.M., Lynch, M.A., Reynolds, J.H., and Smith, S.P., 1985, Intensive sampling of noble gases in fluids at Yellowstone: I. Early overview of data; regional patterns: Geochimica et Cosmochimica Acta, v. 49 , p. 1251-1261.

Kennedy, G.C., 1950, A portion of the system silica-water: Economic Geology, v. 45, p. 629-653.

Kitahara, Shigeto, 1960a, The solubility equilibrium and the rate of solution of quartz in water at high temperatures and high pressures: Review of Physical Chemistry [Japan], v. 30, p. 122-130.

$1960 \mathrm{~b}$, The polymerization of silicic acid obtained by the hydrothermal treatment of quartz and the solubility of amorphous silica: Review of Physical Chemistry [Japan], v. 30, p. 131-137.

Lloyd, E.F., 1959, The hot springs and hydrothermal eruption of Waiotapu: New Zealand Journal of Geology and Geophysics, v. 2, p. 141-176.

Marler, G.D., 1964, Effects of the Hebgen Lake earthquake of August 17, 1959, on the hot springs of the Firehole Geyser Basins, Yellowstone National Park, in The Hebgen Lake, Montana earthquake of August 17, 1959: U.S. Geological Survey Professional Paper 435, p. 185-198.

1973, Inventory of thermal features of the Firehole River Geyser Basins and other selected areas of Yellowstone National Park: National Technical Information Services document PB-221289, 648 p. [Revised 1976 as 2 volumes, 639 p., without change in references.]

Marler, G.D., and White, D.E., 1975, Seismic Geyser and its bearing on the origin and evolution of geysers and hot springs of Yellowstone National Park: Geological Society of America Bulletin, v. 86, p. 749-759.

Morey, G.W., Fournier, R.O., Hemley, J.J., and Rowe, J.J., 1961, Field measurements of silica in water from hot springs and geysers in Yellowstone National Park, Article 269: U.S. Geological Survey Professional Paper 424-C, p. C333-C336.

Morey, G.W., Fournier, R.O., and Rowe, J.J., 1962, The solubility of quartz in water in the temperature interval from $25^{\circ}$ to $300^{\circ} \mathrm{C}$ : Cheochimica et Cosmochimica Acta, v. 26, p. 1029-1043.

Muffler, L.J.P., White, D.E., and Truesdell, A.H., 1971, Hydrothermal explosion craters in Yellowstone National Park: Geological Society of America Bulletin, v. 82, p. 723-740.

Muffler, L.J.P., White, D.E., Truesdell, A.H., and Fournier, R.O., 1982, Geologic map of Lower Geyser Basin, Yellowstone National Park, Wyoming: U.S. Geological Survey Miscellaneous Geologic Investigations Map I-1373, scale 1:24,000.

Murata, K.J., Friedman, Irving, and Gleason, J.D., 1978, Oxygen isotope relation between diagenetic silica minerals in Monterey Shale Temblor Range, Calif.: American Journal of Science, v. 277, p. 259-272.

Murozumi, Masayo, Abiko, Tsutoma, and Nakamura, Seiji, 1966, Geochemical investigation of the Noboribetsu Oyunuma explosion crater lake: Kazan Volcanological Society Japan Bulletin, v. 2, 16 p.

Norris, P.W., 1880, Report upon the Yellowstone National Park, to the Secretary of the Interior, for the year 1879: Washington, Government Printing Office.

Peale, A.C., 1883, Thermal springs, in Hayden, F.V., Twelfth Annual Report of the U.S. Geological and Geographical Survey of the Territories: A report of progress of the exploration in Wyoming and Idaho for the year 1878, Part II: Washington, Government Printing Office, p. 128.

Pearson, F.J., Jr., and Truesdell, A.H., 1978, Tritium in the waters of Yellowstone National Park: U.S. Geological Survey Open-File Report 78-701, p. 327-329.

Pierce, K.L., 1973, Surficial geologic map of the Mammoth quadrangle and part of the Gardiner quadrangle, Yellowstone National Park: U.S. Geological Survey Miscellaneous Geologic Investigations Map I-641, scale 1:62,500.

1979, History and dynamics of glaciation in the northern Yellowstone Park area: U.S. Geological Survey Professional Paper 729-F, $90 \mathrm{p}$. 
Pierce, K.L., Obradovich, J.D., and Friedman, Irving, 1976, Obsidian hydration dating and correlation of Bull Lake and Pinedale glaciation near West Yellowstone, Montana: Geological Society of America Bulletin, v. 87, p. 703-710.

Pitt, A.M., Weaver, C.S., and Spence, William, 1979, The Yellowstone Park earthquake of June 30, 1975: Seismological Society of America Bulletin, v. 69 , p. $187-205$.

Richmond, G.M., 1976, Surficial geologic history of the Canyon Village quadrangle, Yellowstone National Park, Wyoming: U.S. Geological Survey Bulletin 1427, 35 p.

Richmond, G.M., and Waldrop, H.A., 1975, Surficial geologic map of the Norris Junction quadrangle, Yellowstone National Park, Wyoming: U.S. Geological Survey Miscellaneous Geologic Investigations Map I-650, scale 1:62,500.

Rowe, J.J., Fournier, R.O., and Morey, G.W., 1973, Chemical analysis of thermal waters in Yellowstone National Park, Wyoming, 1960-65: U.S. Geological Survey Bulletin 1303, 31 p.

Silberman, M.L., White, D.E., Keith, T.E.C., and Docktor, R.D., 1979, Duration of hydrothermal activity at Steamboat Springs, Nevada, from ages of the spacially associated volcanic rock: U.S. Geological Survey Professional Paper 458-D, $14 \mathrm{p}$.

Smith, R.B., and Christiansen, R.L., 1980, Yellowstone Park as a window on the earth's interior: Scientific American, v. 242, p. 104-117.

Smith, R.B., Shuey, R.T., Pelton, J.R., and Bailey, J.P., 1977, Yellowstone hot spot: Contemporary tectonics and crustal properties from earthquake and aeromagnetic data: Journal of Geophysical Research, v. 82, p. 3665-3676.

Thompson, J.M., Presser, T.S., Barnes, R.B., and Bird, D.B., 1975, Chemical analysis of the waters of Yellowstone National Park, Wyoming, from 1965-73:U.S. Geological Survey Open-File Report 75-25, $59 \mathrm{p}$.

Thompson, J.M., and Yadav, Sandhya, 1979, Chemical analyses of waters from geysers, hot springs, and pools in Yellowstone National Park, Wyoming, from 1974 to 1978: U.S. Geological Survey Open-File Report 79-704, $49 \mathrm{p}$.

Trimble, A.B., and Smith, R.B., 1975, Seismicity and contemporary tectonics of the Hebgen Lake-Yellowstone Park region: Journal of Geophysical Research, v. 80, p. 733-741.

Truesdell, A.H., 1976, Summary of Section III, Geochemical techniques in exploration: United Nations Symposium on the Development and Use of Geothermal Resources, 2nd, San Francisco, 1975, Proceedings, Vol. 1, p. liii-lxxix.

Truesdell, A.H., and Fournier, R.O., 1976, Conditions in the deeper parts of the hot spring systems of Yellowstone National Park, Wyoming: U.S. Geological Survey Open-File Report 76-428, 30 p.

Truesdell, A.H., Rye, R.O., Whelan, J.F., and Thompson, J.M., 1978, Sulfate chemical and isotopic patterns in thermal waters of Yellowstone National Park, Wyoming: U.S. Geological Survey OpenFile Report 78-701, p. 435-436.

Turner, D.S., 1949, Development of a new thermal feature in Yellowstone National Park: Transactions of the American Geophysical Union, v. 30, p. 526-527.

U.S. Geological Survey, 1972, Geologic map of the Yellowstone National Park: U.S. Geological Survey Miscellaneous Geologic Investigations
Map I-711, scale 1:125,000.

Waldrop, H.A., and Pierce, K.L., 1975, Surficial geologic map of the Madison Junction quadrangle, Yellowstone National Park, Wyoming: U.S. Geological Survey Miscellaneous Geologic Investigations Map I-651, scale 1:62,500.

Watson, W.V., 1954, unpublished manuscript on Norris Geyser Basin: Yellowstone Library and Museum Association, copies in files of Yellowstone Library, Mammoth and Norris Museums.

Weaver, C.E., 1956, The distribution and identification of mixed-layer clays in sedimentary rocks: American Mineralogist, v. 41, p. 202-221.

Weed, W.W., and Pirsson, L.V., 1891, Occurrence of sulphur, orpiment, and realgar in the Yellowstone National Park: American Journal of Science, 3d ser., v. 42 (142), p. 401-405.

White, D.E., 1955, Thermal springs and epithermal ore deposits: Economic Geology, Fiftieth Anniversary volume, p. 99-154. 1957, Thermal waters of volcanic origin: Geological Society of America Bulletin, v. 68, p. 1637-1657.

1967, Some principles of geyser activity, mainly from Steamboat Springs, Nevada: American Journal of Science, v. 265, no. 8, p. $641-684$.

1968, Hydrology, activity, and heat flow of the Steamboat Springs thermal systems, Washoe County, Nevada: U.S. Geological Survey Professional Paper 458-C, 109 p.

1969, Rapid heat-flow surveying of geothermal areas, utilizing individual snowfalls as calorimeters: Journal of Geophysical Research, v. 74, p. 5191-5201.

1970 , Geochemistry applied to the discovery, evaluation, and exploitation of geothermal energy resources, Rapporteur's report, sec. 5, in United Nations Symposium on the Development and Utilization of Geothermal Resources, Pisa, 1970: Geothermics Special Issue 2, v. 1, p. 58-80.

1978, Conductive heat flows in research drill holes in thermal areas of Yellowstone National Park, Wyoming: U.S. Geological Survey Journal of Research, v. 6, p. 765-774.

White, D.E., Brannock, W.W., and Murata, K.J., 1956, Silica in hotspring waters: Geochimica et Cosmochimica Acta, v. 10, p. 27-59.

White, D.E., Fournier, R.O., Muffler, L.J.P., and Truesdell, A.H., 1975, Physical results from research drilling in thermal areas of Yellowstone Park, Wyoming: U.S. Geological Survey Professional Paper 892, 77 p.

White, D.E., Hem, J.D., and Waring, G.A., 1963, Chemical composition of subsurface waters, in Data of geochemistry, Sixth Edition: U.S. Geological Survey Professional Paper 440-F, p. F46-F47.

White, D.E., Muffler, L.J.P., and Truesdell, A.H., 1971, Vapordominated hydrothermal systems compared with hot-water systems: Economic Geology, v. 66, p. 75-97.

White, D.E., Thompson, G.A., and Sandberg, C.S., 1964, Rocks, structure, and geologic history of Steamboat Springs thermal area, Washoe County, Nevada: U.S. Geological Survey Professional Paper $458-\mathrm{B}, 63 \mathrm{p}$.

Yellowstone informal records [various years and observers]: Yellowstone National Park, variously paged [available for inspection at Norris and (or) Mammoth Museums]. 


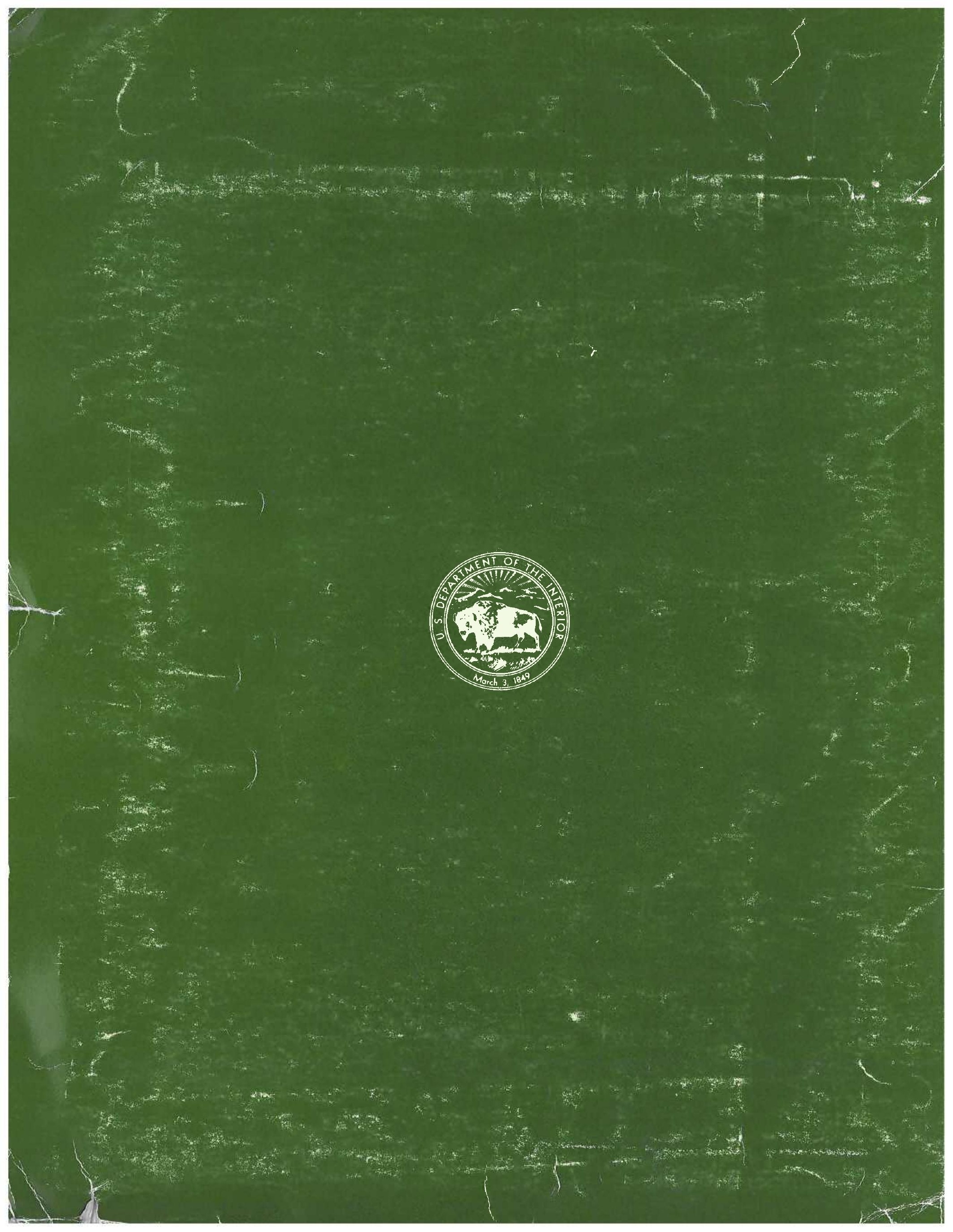

